Prepared in cooperation with the Bureau of Land Management and the Great Plains Landscape Conservation Cooperative

\title{
Southern Great Plains Rapid Ecoregional Assessment Volume I. Ecological Communities
}

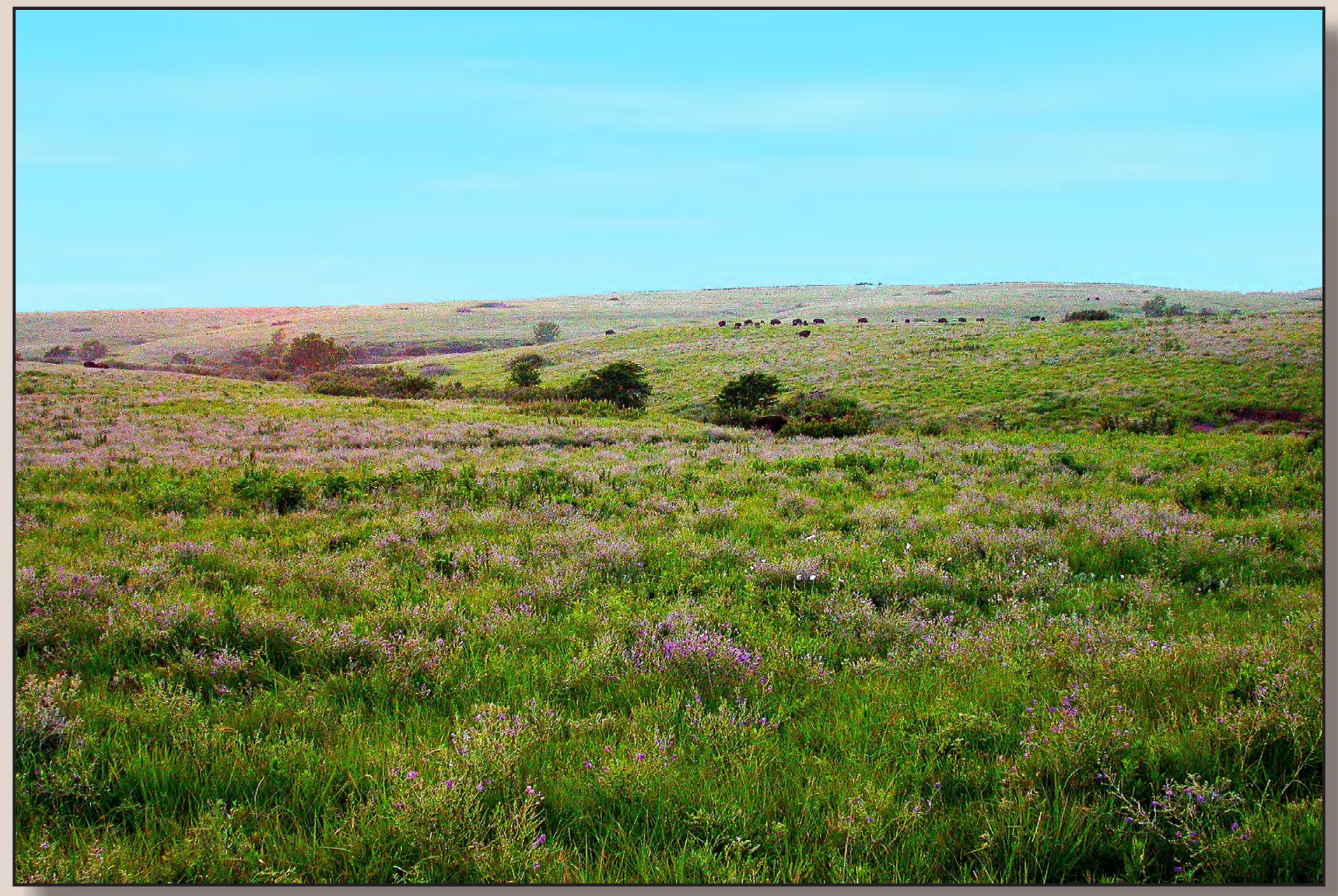

Open-File Report 2017-1100 
Cover. Flint Hills, Nebraska. Photograph by Edwin Olson, 2003. 


\section{Southern Great Plains Rapid Ecoregional Assessment- Volume 1. Ecological Communities}

By Gordon C. Reese, Lucy Burris, Natasha B. Carr, Ian I.F. Leinwand, and Cynthia P. Melcher

Prepared in cooperation with the Bureau of Land Management and the Great Plains Landscape Conservation Cooperative

Open-File Report 2017-1100 


\title{
U.S. Department of the Interior \\ RYAN K. ZINKE, Secretary
}

\section{U.S. Geological Survey William H. Werkheiser, Acting Director}

\author{
U.S. Geological Survey, Reston, Virginia: 2017
}

For more information on the USGS - the Federal source for science about the Earth, its natural and living resources, natural hazards, and the environment-visit https://www.usgs.gov or call 1-888-ASK-USGS.

For an overview of USGS information products, including maps, imagery, and publications, visit https://store.usgs.gov.

Any use of trade, firm, or product names is for descriptive purposes only and does not imply endorsement by the U.S. Government.

Although this information product, for the most part, is in the public domain, it also may contain copyrighted materials as noted in the text. Permission to reproduce copyrighted items must be secured from the copyright owner.

Suggested citation:

Reese, G.C., Burris, Lucy, Carr, N.B., Leinwand, I.I.F., and Melcher, C.P., 2017, Southern Great Plains Rapid Ecoregional Assessment—Volume I. Ecological communities: U.S. Geological Survey Open-File Report 2017-1100, 126 p., https://doi.org/10.3133/ofr20171100.

ISSN 0196-1497 (print)

ISSN 2331-1258 (online) 


\section{Acknowledgments}

The impetus and oversight for this project was provided by the Southern Great Plains Rapid Ecoregional Assessment advisors including Steve Tryon, Melanie Barnes, David Wood, Kevin Miller, George Thomas, Janine Book, Laurence Levesque, Carolyn Russell of the Bureau of Land Management and Nicole Athearn of the Great Plains Landscape Conservation Cooperative. We greatly appreciate reviews of maps and the manuscript provided by Dan Baggao, Robert Means, Chuck Schmidt, and George Soehn of the Bureau of Land Management; Duane German, Russell Martin, and Amie Treuer-Kuehn, Texas Parks and Wildlife; Russ Horton, Oklahoma Department of Wildlife Conservation; Alex Daniels and Anne Bartuszevige, Playa Lakes Joint Venture; Lee Elliot, Missouri Resource Assessment Partnership; Rick Schneider, Nebraska Natural Heritage Program; Esteban Muldavin, New Mexico Natural Heritage Program; Bruce Hoagland, Oklahoma Natural Heritage Inventory; Joe Stevens, Joanna Lemly, Karin Decker, and Michael Menefee, Colorado Natural Heritage Program; Patrick J. Comer, NatureServe; Steven Rolfsmeier, Chadron State College; Kelly Kindscher, Kansas Biological Survey; and Timothy Assal, Greg Auble, Tammy Fancher, Steve Germaine, Daniel Manier, Laura Perry, Jonathan Friedman, Susan Skagen, Helen Sofaer, Colin Talbert, and David Walters, U.S. Geological Survey. Catherine Jarnevich, U.S. Geological Survey, assisted with the tamarisk and Russian olive models.

The following organizations developed or contributed to the datasets used in the Rapid Ecoregional Assessment: the Bureau of Land Management, Bureau of Meteorology (Australia), Colorado Division of Water Resources, Commonwealth Scientific and Industrial Research Organization, Community Earth System Model Contributors (National Science Foundation, Department of Energy, National Center for Atmospheric Research), Global Biodiversity Information Facility, IHS, Kansas Biological Survey, Kansas Geological Survey, National Agricultural Statistics Service, Nebraska Department of Natural Resources, New Mexico Office of the State Engineer, Oklahoma Water Resources Board, Playa Lakes Joint Venture, South Dakota Department of Environment and Natural Resources, Texas Commission on Environmental Quality, Texas Parks and Wildlife Department, Texas Tech University, Texas Water Development Board, U.S. Army Corps of Engineers, U.S. Census Bureau, U.S. Department of Transportation, U.S. Environmental Protection Agency, U.S. Forest Service, U.S. Geological Survey, World Climate Research Programme's Working Group on Coupled Modelling, Wyoming Water Development Commission, and the Wyoming State Engineer's Office. 



\section{Contents}

Acknowledgments ..................................................................................................................ii

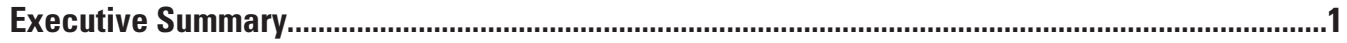

Chapter 1. Introduction and Overview …......................................................................

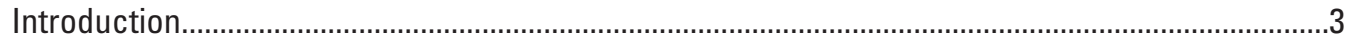

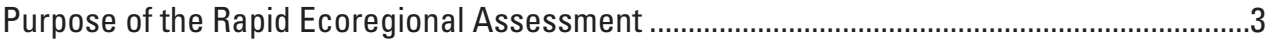

Management Implications .............................................................................................................

Components of the Rapid Ecoregional Assessment..............................................................

Overview of the Rapid Ecoregional Assessment Process........................................................

Southern Great Plains Rapid Ecoregional Assessment ...............................................................

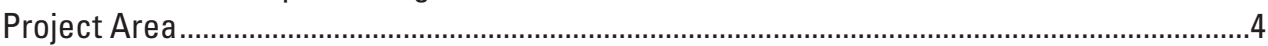

Management Questions ...........................................................................................................

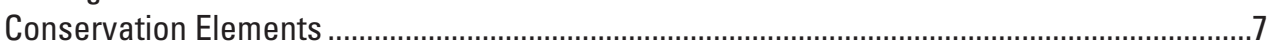

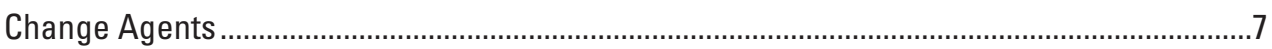

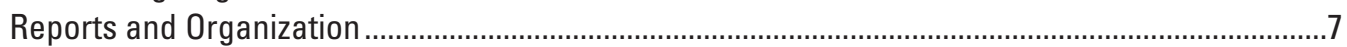

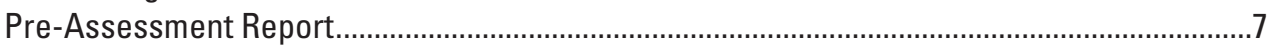

Rapid Ecoregional Assessment Reports...................................................................................9

Accessing the Rapid Ecoregional Assessment Datasets .........................................................

References Cited.................................................................................................................

Chapter 2. Methods Overview …......................................................................................11

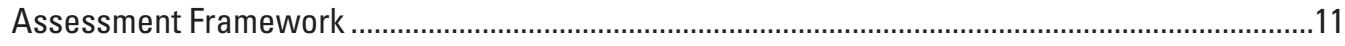

Core Management Questions ...........................................................................................11

Integrated Management Question............................................................................................11

Scale of Analysis for Management Questions ......................................................................11

Baseline Distributions for Evaluating Change Agents...........................................................11

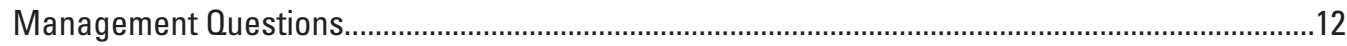

Core Management Questions for Evaluating Current and Future Change Agents .................12

Core Management Questions for Evaluating Terrestrial Communities.....................................14

Core Management Questions for Evaluating Aquatic Communities .......................................15

Integrated Management Question for Evaluating Terrestrial and Aquatic Communities........15

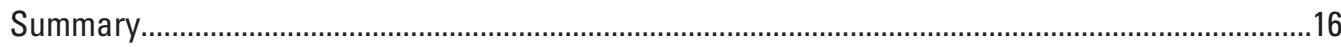

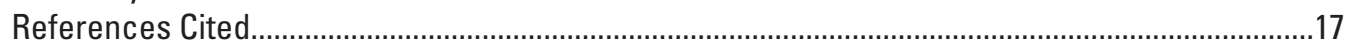

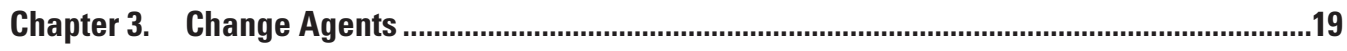

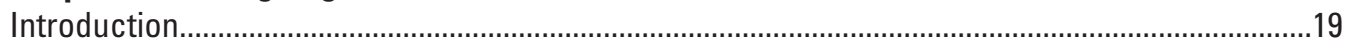

Change Agents and Management Questions ............................................................................19

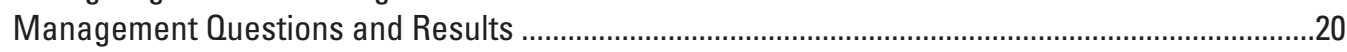

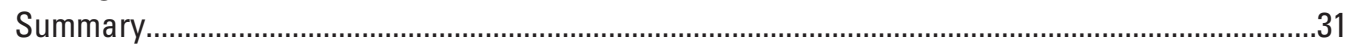

References Cited...........................................................................................................

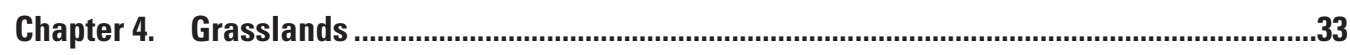

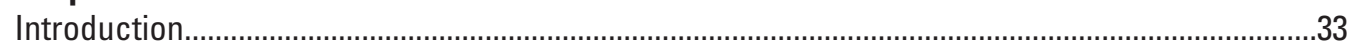

Rapid Ecoregional Assessment Components Evaluated for Grasslands ......................................33

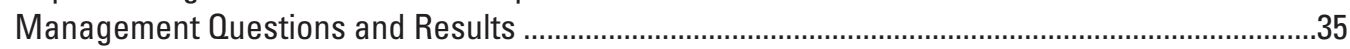

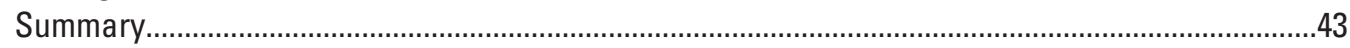

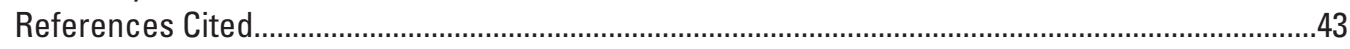

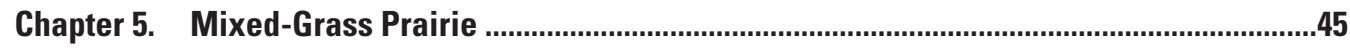

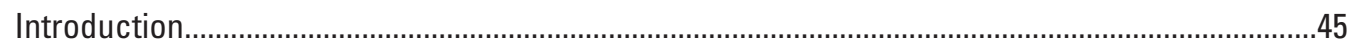

Rapid Ecoregional Assessment Components Evaluated for Mixed-Grass Prairie ...........................45

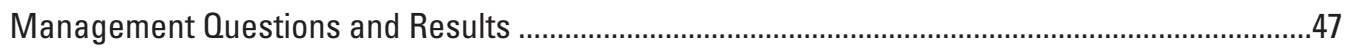

Summary

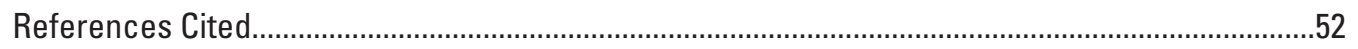




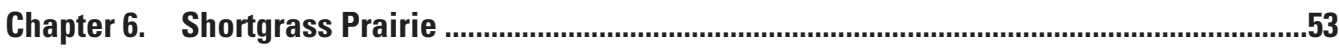

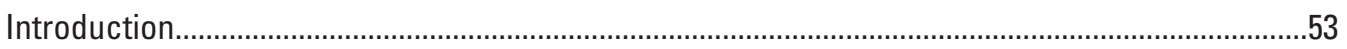

Rapid Ecoregional Assessment Components Evaluated for Shortgrass Prairie..............................53

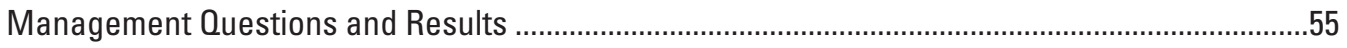

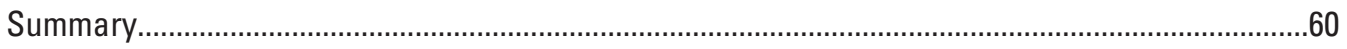

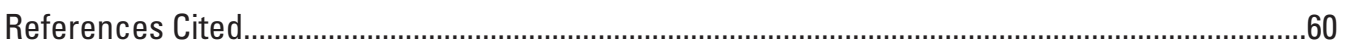

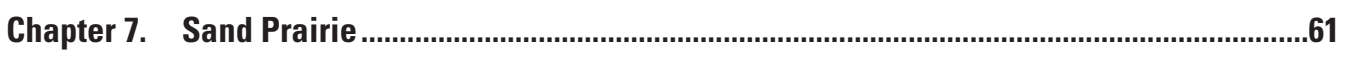

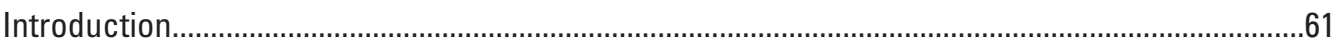

Rapid Ecoregional Assessment Components Evaluated for Sand Prairie .....................................61

Management Questions and Results ......................................................................................63

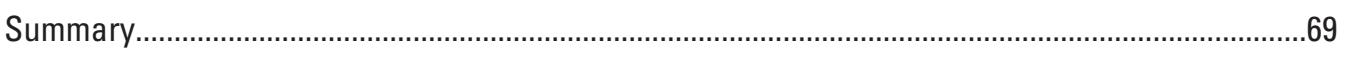

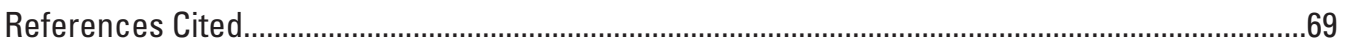

Chapter 8. Riparian and Nonplaya Wetlands.....................................................................71

Introduction.......................................................................................................................

Rapid Ecoregional Assessment Components Evaluated for Riparian and Nonplaya Wetlands ........71

Management Questions and Results .......................................................................................73

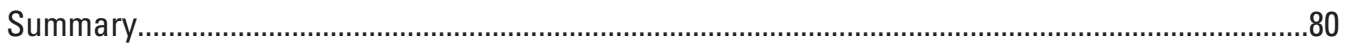

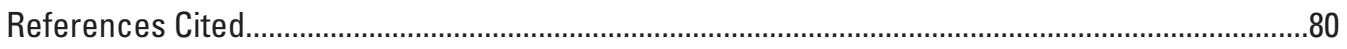

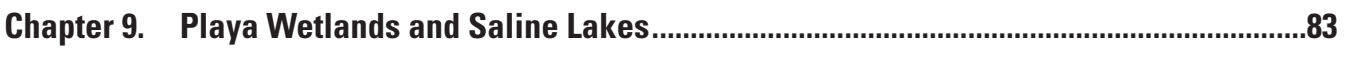

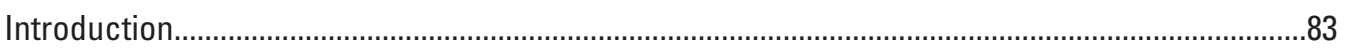

Rapid Ecoregional Assessment Components Evaluated for Playa Wetlands and Saline Lakes........83

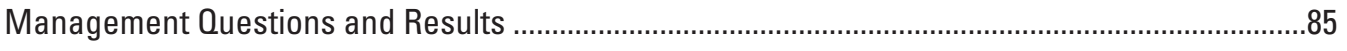

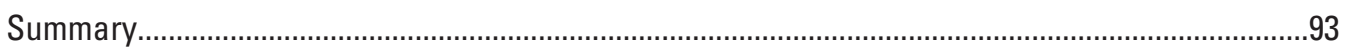

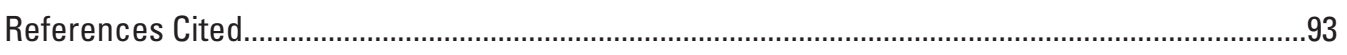

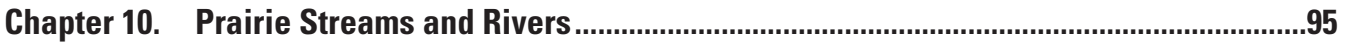

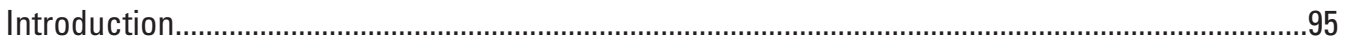

Rapid Ecoregional Assessment Components Evaluated for Prairie Streams and Rivers ..............95

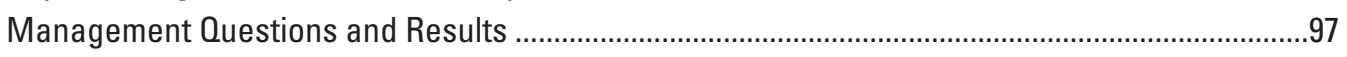

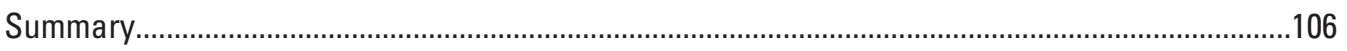

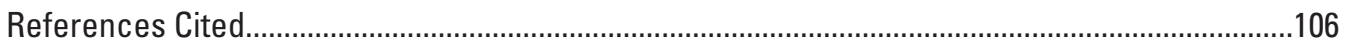

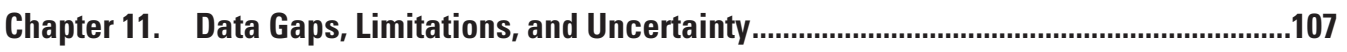

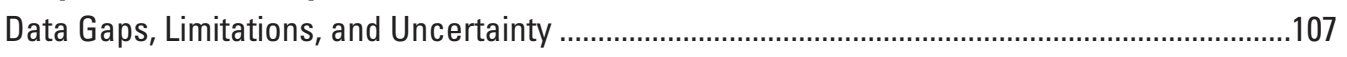

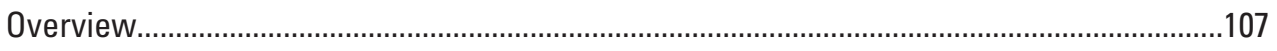

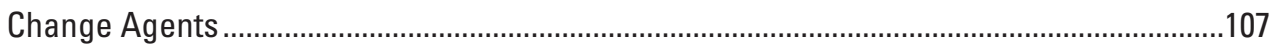

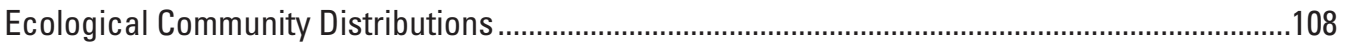

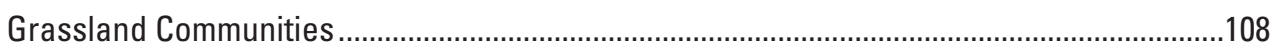

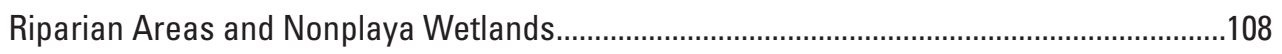

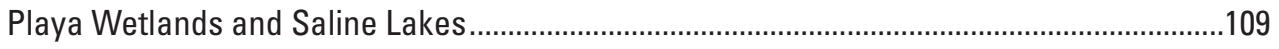

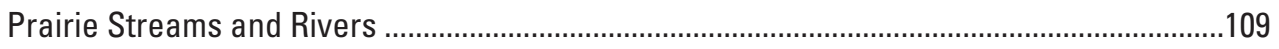

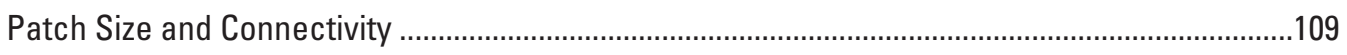

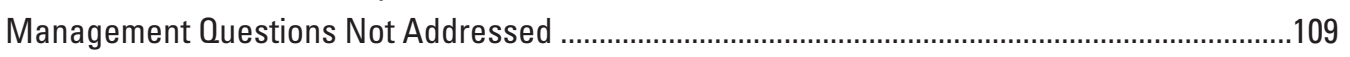

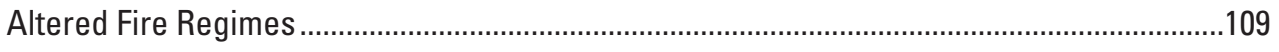

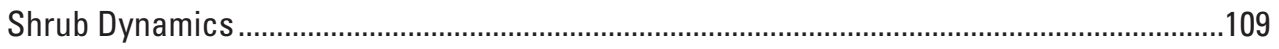

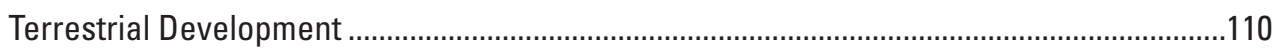

Aquatic Development...............................................................................................

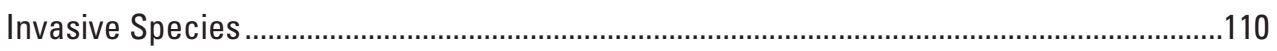


Conservation Reserve Program ......................................................................................

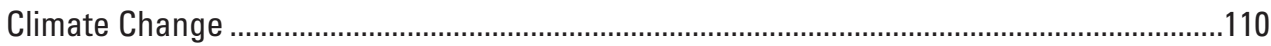

Poisoning/Herbicides/Pesticides ...................................................................................110

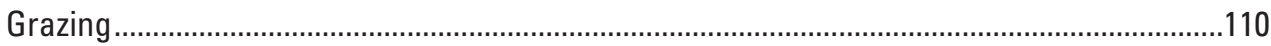

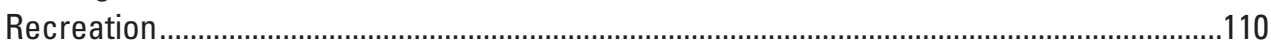

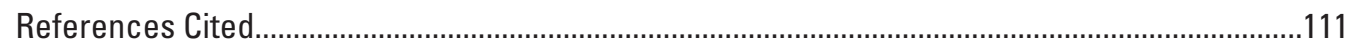

Appendix A. Methodological Details for Derived Datasets ...................................................113

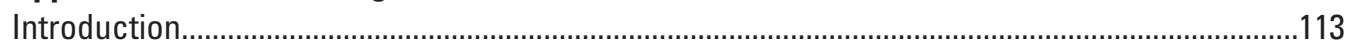

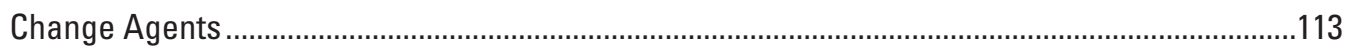

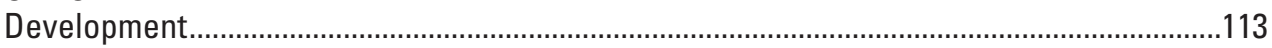

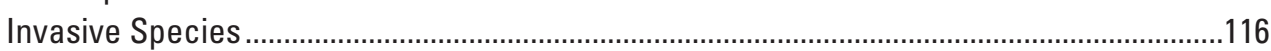

Ecological Communities.........................................................................................................118

Terrestrial Community Baseline Distribution Mapping .......................................................118

Aquatic Community Baseline Distribution Mapping .............................................................118

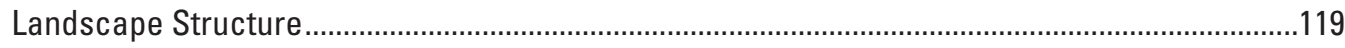

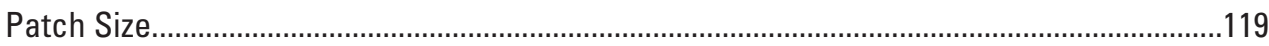

Landscape-Level Area Ranking Breakpoints: Calculating Equal Subsets of the Data ..................120

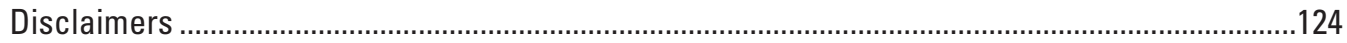

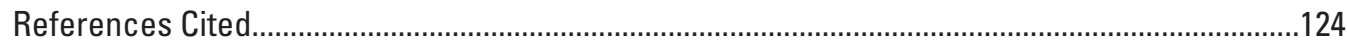

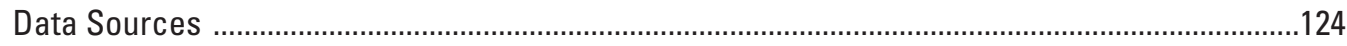

\section{Figures}

1-1. Map showing Southern Great Plains Rapid Ecoregional Assessment boundary..............5

1-2. Map showing land ownership and jurisdictions for the Southern Great Plains ................6

1-3. Map showing distribution of ecological communities in the Southern Great Plains........8

2-1. Diagram showing overview of the process for deriving the terrestrial development

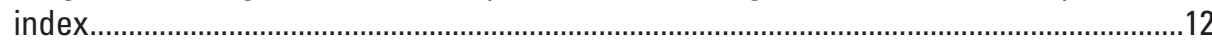

2-2. Diagram showing overview of the process for deriving the aquatic development

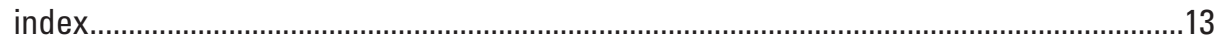

2-3. Diagram showing overall landscape-level ranks .............................................................16

2-4. Diagram showing overview of the process used to address the core and integrated management questions ....................................................................................................

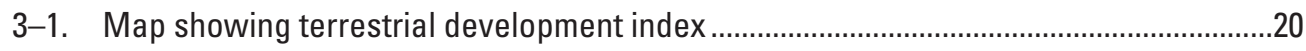

3-2. Graph showing total area in each terrestrial development index class ..........................21

3-3. Maps showing terrestrial development index for agricultural croplands and

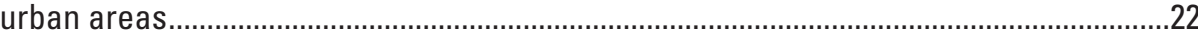

3-4. Maps showing terrestrial development index for transportation and energy

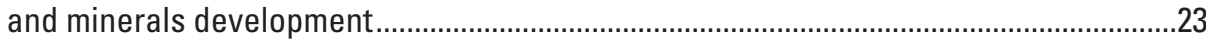

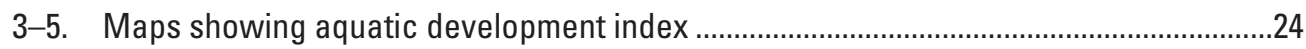

3-6. Graph showing total area in aquatic development index classes ..................................25

3-7. Maps showing aquatic development index for three classes of development ...............25

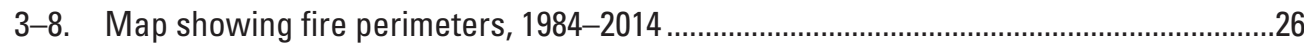

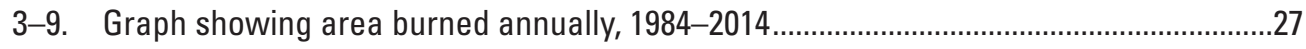

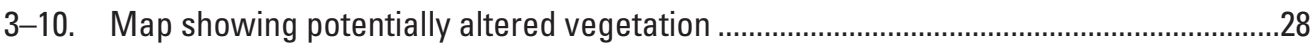

3-11. Maps showing average annual temperatures for 1981-2010, a hot and dry scenario for 2016-2045 and 2046-2075, and a warm and wet scenario for 2016-2045 and 2046-2075 
3-12. Maps showing average annual precipitation for 1981-2010, a hot and dry scenario for 2016-2045 and 2046-2075, and a warm and wet scenario for 2016-2045 and 2046-2075.

4-1. Map showing estimated historical distribution of grasslands ........................................35

4-2. Map showing baseline distribution of grasslands .........................................................36

4-3. Map showing terrestrial development index for baseline grasslands .............................37

4-4. Graph showing area of baseline grasslands by terrestrial development index class ........... 38

4-5. Graph showing area of grasslands as a function of patch size........................................38

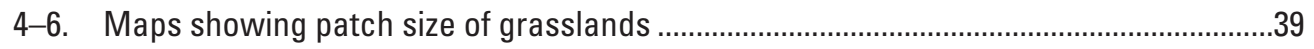

4-7. Maps showing occurrences of honey mesquite, eastern redcedar, and either species.

4-8. Maps showing potential changes in grasslands distribution as projected by

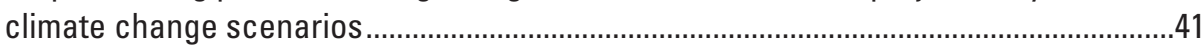

4-9. Maps showing landscape-level summaries for grasslands...........................................42

5-1. Map showing baseline and converted historical distributions of mixed-grass prairie.......... 47

5-2. Map showing terrestrial development index for baseline mixed-grass prairie...............48

5-3. Graph showing area of baseline mixed-grass prairie by terrestrial development

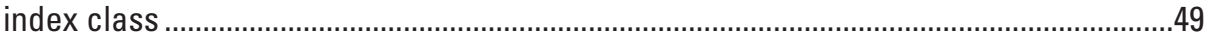

5-4. Graph showing area of mixed-grass prairie as a function of patch size .............................49

5-5. Maps showing patch size of mixed-grass prairie ....................................................50

5-6. Maps showing landscape-level summaries for mixed-grass prairie ...............................51

6-1. Map showing baseline and converted historical distributions of shortgrass prairie .........55

6-2. Map showing terrestrial development index for baseline shortgrass prairie ..................56

6-3. Graph showing area of baseline shortgrass prairie by terrestrial development

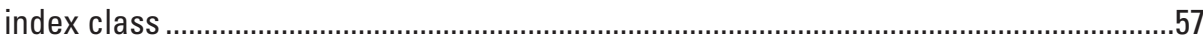

6-4. Graph showing area of shortgrass prairie as a function of patch size ................................57

6-5. Maps showing patch size of shortgrass prairie ...........................................................58

6-6. Maps showing landscape-level summaries for shortgrass prairie ................................59

7-1. Map showing baseline and converted historical distributions of sand prairie................63

7-2. Map showing baseline distributions of sand sagebrush and shinnery oak within the sand prairie community .64

7-3. Map showing terrestrial development index for baseline sand prairie ............................65

7-4. Graph showing area of baseline sand prairie by terrestrial development index class.......... 66

7-5. Graph showing area of sand prairie as a function of patch size ...................................66

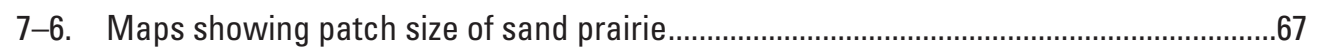

7-7. Maps showing landscape-level summaries for sand prairie...........................................68

8-1. Map showing baseline distribution of riparian and nonplaya wetlands ..........................73

8-2. Map showing percentage of each sixth-level watershed classified as riparian

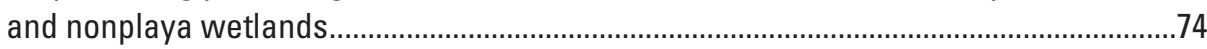

8-3. Map showing aquatic development index for baseline riparian and nonplaya wetlands.

8-4. Graph showing area of baseline riparian and nonplaya wetlands by aquatic

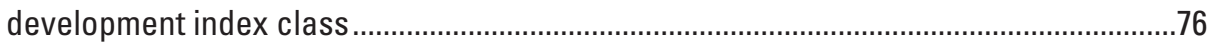

8-5. Graph showing area of riparian and nonplaya wetlands as a function of patch size ............ 76

8-6. Map showing probability of suitable habitat and reported occurrences for Russian olive. 
8-7. Map showing probability of suitable habitat and reported occurrences for tamarisk .......... 78

8-8. Maps showing landscape-level summaries for riparian and nonplaya wetlands...........79

9-1. Map showing baseline distribution of playa wetlands..........................................................85

9-2. Map showing baseline distribution of saline lakes.............................................................86

9-3. Map showing area of baseline playa wetlands as a percentage of sixth-level

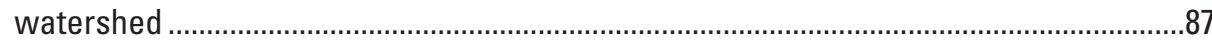

9-4. Map showing local aquatic development index for baseline playa wetlands................88

9-5. Map showing local aquatic development index for baseline saline lakes....................89

9-6. Graphs showing area of playa wetlands and saline lakes by local aquatic development index class ..............................................................................................90

9-7. Graphs showing area of playa wetlands and saline lakes as a function of patch size.......... 91

9-8. Maps showing landscape-level summaries for playa wetlands and saline lakes ..........92

10-1. Map showing baseline distribution of prairie streams and rivers by hydroperiod..........97

10-2. Map showing total length of perennial streams.............................................................98

10-3. Map showing total length of intermittent streams........................................................99

10-4. Map showing aquatic development index for baseline perennial streams....................100

10-5. Map showing aquatic development index for baseline intermittent streams................101

10-6. Graphs showing length of prairie streams and rivers by aquatic development index class 102

10-7. Graph showing total length of perennial streams as a function of stream-segment size class.

10-8. Map showing potential barriers in perennial streams ...................................................104

10-9. Maps showing landscape-level summaries for prairie streams and rivers ...................105

A-1. Maps showing terrestrial development index score and the contributing footprint from development for two landscapes ...........................................................................115

A-2. Diagram of the local and upstream contributing areas for a local catchment..............116

A-3. Maps showing components of the aquatic development index summarized by catchment.

A-4. Graphs showing total area in aquatic development index classes .............................118

\section{Tables}

1-1. Ecological communities evaluated as conservation elements..........................................7

3-1. Change agents and associated indicators used to address management questions........19

3-2. Management questions addressed for change agents ................................................19

3-3. Area of ecological communities burned, 1984-2014..............................................................27

4-1. Key ecological attributes and associated indicators used to address core management questions for grasslands......

4-2. Anthropogenic change agents and associated indicators used to address core management questions for grasslands

4-3. Landscape-level variables used to address the integrated management question for grasslands

4-4. Management questions addressed for grasslands. .34

5-1. Key ecological attributes and associated indicators used to address core management questions for mixed-grass prairie 
5-2. Anthropogenic change agents and associated indicators used to address core management questions for mixed-grass prairie

5-3. Landscape-level variables used to address the integrated management question for mixed-grass prairie..

5-4. Management questions addressed for mixed-grass prairie ............................................46

6-1. Key ecological attributes and associated indicators used to address core management questions for shortgrass prairie

6-2. Anthropogenic change agents and associated indicators used to address core management questions for shortgrass prairie

6-3. Landscape-level variables used to address the integrated management question for shortgrass prairie

6-4. Management questions addressed for shortgrass prairie...

7-1. Key ecological attributes and associated indicators used to address core management questions for sand prairie

7-2. Anthropogenic change agents and associated indicators used to address core management questions for sand prairie

7-3. Landscape-level variables used to address the integrated management question for sand prairie.

7-4. Management questions addressed for sand prairie

8-1. Key ecological attributes and associated indicators used to address core management questions for riparian and nonplaya wetlands

8-2. Anthropogenic change agents and associated indicators used to address core management questions for riparian and nonplaya wetlands.

8-3. Landscape-level variables used to address the integrated management question for riparian and nonplaya wetlands

8-4. Management questions addressed for riparian and nonplaya wetlands... .72

9-1. Key ecological attributes and associated indicators used to address core management questions for playa wetlands and saline lakes

9-2. Anthropogenic change agents and associated indicators used to address core management questions for playa wetlands and saline lakes

9-3. Landscape-level variables used to address the integrated management question for playa wetlands and saline lakes.

9-4. Management questions addressed for playa wetlands and saline lakes..

10-1. Key ecological attributes and associated indicators used to address core management questions for prairie streams and rivers.

10-2. Anthropogenic change agents and associated indicators used to address core management questions for prairie streams and rivers.

10-3. Landscape-level variables used to address the integrated management question for prairie streams and rivers

10-4. Management questions addressed for prairie streams and rivers.................................96

A-1. Data sources used to quantify change agents .............................................................114

A-2. Relations between component variables and metrics for the overall aquatic development index and key ecological attributes for prairie streams and rivers .........115

A-3. Variables used in the Russian olive and tamarisk distribution models. .119

A-4. Data sources used to map the distribution of baseline ecological communities..........119

A-5. Cover types classified from LANDFIRE Existing Vegetation Types .120 


\section{Conversion Factors}

SI to Inch/Pound

\begin{tabular}{lcl}
\hline \multicolumn{1}{c}{ Multiply } & By & \multicolumn{1}{c}{ To obtain } \\
\hline & Length & \\
\hline meter $(\mathrm{m})$ & 3.281 & foot $(\mathrm{ft})$ \\
meter $(\mathrm{m})$ & 1.094 & yard $(\mathrm{yd})$ \\
kilometer $(\mathrm{km})$ & 0.6214 & mile $(\mathrm{mi})$ \\
\hline & Area & \\
\hline square meter $\left(\mathrm{m}^{2}\right)$ & 10.76 & square foot $\left(\mathrm{ft}^{2}\right)$ \\
hectare $(\mathrm{ha})$ & 2.471 & acre \\
square kilometer $\left(\mathrm{km}^{2}\right)$ & 0.3861 & square mile $\left(\mathrm{mi}^{2}\right)$ \\
\hline & Volume & \\
\hline cubic meters $\left(\mathrm{m}^{3}\right)$ & 0.0008107 & acre-feet \\
\hline
\end{tabular}

Temperature in degrees Celsius $\left({ }^{\circ} \mathrm{C}\right)$ may be converted to degrees Fahrenheit $\left({ }^{\circ} \mathrm{F}\right)$ as follows:

$$
{ }^{\circ} \mathrm{F}=\left(1.8 \times{ }^{\circ} \mathrm{C}\right)+32
$$

Temperature in degrees Fahrenheit $\left({ }^{\circ} \mathrm{F}\right)$ may be converted to degrees Celsius $\left({ }^{\circ} \mathrm{C}\right)$ as follows:

$$
{ }^{\circ} \mathrm{C}=\left({ }^{\circ} \mathrm{F}-32\right) / 1.8
$$

\section{Scientific Notation}

\begin{tabular}{cl}
\hline Symbol & \multicolumn{1}{c}{ Meaning } \\
\hline$<$ & Less than \\
$\leq$ & Less than or equal to \\
$=$ & Equals \\
$>$ & Greater than \\
$\geq$ & Greater than or equal to \\
\hline
\end{tabular}

\section{Abbreviations}

$\begin{array}{ll}\text { ADI } & \text { aquatic development index } \\ \text { BLM } & \text { Bureau of Land Management } \\ \text { BpS } & \text { Biophysical Settings } \\ \text { DOI } & \text { Department of the Interior } \\ \text { EVT } & \text { Existing Vegetation Type } \\ \text { GAP } & \text { Gap Analysis Program (U.S. Geological Survey) } \\ \text { GPLCC } & \text { Great Plains Landscape Conservation Cooperative } \\ \text { NHD } & \text { National Hydrography Dataset (U.S. Geological Survey) } \\ \text { NRCS } & \text { Natural Resources Conservation Service } \\ \text { REA } & \text { Rapid Ecoregional Assessment } \\ \text { SAHM } & \text { Software for Assisted Habitat Modeling } \\ \text { SGP } & \text { Southern Great Plains } \\ \text { TDI } & \text { terrestrial development index }\end{array}$




\section{Species Names}

\section{Plants}

big bluestem (Andropogon gerardii)

blowout penstemon (Penstemon haydenii)

blue grama (Bouteloua gracilis)

buffalograss (Bouteloua dactyloides)

cottonwood (Populus spp.)

little bluestem (Schizachyrium scoparium)

honey mesquite (Prosopis glandulosa)

eastern redcedar (Juniperus virginiana)

one-seeded juniper (Juniperus monosperma)

Russian olive (Elaeagnus angustifolia)

sand sagebrush (Artemisia filifolia)

sand shinnery oak (Quercus havardii)

sideoats grama (Bouteloua curtipendula)

tamarisk (Tamarix spp.)

western wheatgrass (Pascopyrum smithii)

willow (Salix spp.)

\section{Birds}

burrowing owl (Athene cunicularia hypugaea)

ferruginous hawk (Buteo regalis)

interior least tern (Sternula antillarum athalassos)

lesser prairie chicken (Tympanuchus pallidicinctus)

long-billed curlew (Numenius americanus)

mountain plover (Charadrius montanus)

snowy plover (Charadrius nivosus)

\section{Mammals}

black-tailed prairie dog (Cynomys ludovicianus)

mule deer (Odocoileus hemionus)

swift fox (Vulpes velox) 


\section{Fish}

Arkansas River shiner (Notropis girardi)

\section{Reptiles}

dunes sagebrush lizard (Sceloporus arenicolus)

western massasauga (Sistrurus catenatus tergeminus)

\section{Contributing Authors}

Lucy Burris

U.S. Geological Survey, Fort Collins Science Center, Fort Collins, Colo.

Natasha B. Carr

U.S. Geological Survey, Fort Collins Science Center, Fort Collins, Colo.

Ian I.F. Leinwand

Cherokee National Technologies, on contract to U.S. Geological Survey, Fort Collins Science Center, Fort Collins, Colo.

Cynthia P. Melcher

U.S. Geological Survey, Fort Collins Science Center, Fort Collins, Colo.

Gordon C. Reese

U.S. Geological Survey, Fort Collins Science Center, Fort Collins, Colo. 



\section{Executive Summary}

\section{Rapid Ecoregional Assessments}

The overall goal of the Bureau of Land Management (BLM) Rapid Ecoregional Assessments (REAs) is to compile and synthesize regional datasets to facilitate evaluation of the cumulative effects of change agents on priority species and communities. More specifically, the REAs identify and map the distribution of priority communities and wildlife habitats at broad spatial extents and provide assessments of ecological conditions. The REAs also identify where and to what degree ecological resources are currently at risk from change agents - natural processes or human activities that drive ecosystem change - such as development, fire, invasive species, and climate change. The REAs can help managers identify and prioritize potential areas for conservation or restoration, assess cumulative effects as required by the National Environmental Policy Act, and inform landscape-level planning and management decisions for multiple uses of public lands. Overall, the REAs provide a vehicle for creating stronger, more effective, and more efficient collaboration and cooperation among all parties interested in regional land and resource management and thereby support the BLM landscape approach to resource management.

\section{Rapid Ecoregional Assessment Components}

There are several components to the REAs. Management questions, developed by the BLM and other stakeholders, identify the regionally significant information needed to address land-management responsibilities. Conservation elements represent ecological communities and species that are of regional management concern. The emphasis on ecological communities is based on the premise that intact and functioning ecological systems are more resistant and resilient to change agents, including both natural and human stressors. Because it is not feasible to manage or monitor all species individually, the protection of intact ecological communities may serve as a safety net for species not addressed specifically by the REA. Species or species assemblages of management concern not adequately addressed at the community level may be specifically addressed as conservation elements. The REA identifies and assesses the primary factors, or change agents, that currently affect or are likely to affect the condition of communities and species in the future.

\section{The Southern Great Plains Rapid Ecoregional Assessment}

The BLM partnered with the Great Plains Landscape Conservation Cooperative (GPLCC) to ensure that the results of the Southern Great Plains REA provide information useful in addressing management issues identified by a diverse set of stakeholders representing both the REA and the GPLCC. The Southern Great Plains (SGP) REA project area includes the full extent of the GPLCC area and four level-III ecoregions: High Plains, Central Great Plains, Southwestern Tablelands, and Nebraska Sand Hills. The project area for this REA is the largest of all completed REAs; it encompasses 961,105 square kilometers (371,085 square miles) and includes portions of Colorado, Kansas, Nebraska, New Mexico, Oklahoma, South Dakota, Texas, and Wyoming.

The Southern Great Plains REA is summarized in a series of three reports. The pre-assessment report summarizes the process used by the REA stakeholders to select management questions, conservation elements, and change agents. It also provides background information for each conservation element selected including a description of the key ecological attributes and change agents, which are summarized in a conceptual model and tables. Volume I of the Southern Great Plains REA report (this volume) provides background information, methods, summaries, and data gaps for all the ecological communities evaluated for the Southern Great Plains REA. Volume II will address the species and species assemblages evaluated for the Southern Great Plains REA.

Seven major ecological communities were evaluated as conservation elements for the Southern Great Plains REA. Of those seven, three are grassland communities: mixed-grass prairie, shortgrass prairie, and sand prairie. We also addressed management questions for the three grassland communities collectively and included other grassland types present in the project area, but not addressed individually: tallgrass, northwest mixed-grass, and cool-season bunchgrass prairies; foothill and saline grasslands; and semidesert grassland and shrubland. The three aquatic communities evaluated are riparian and nonplaya wetlands, playa wetlands and saline lakes, and prairie streams and rivers. A total of 13 species and species assemblages were selected for the Southern Great Plains REA (addressed in volume II): freshwater mussel assemblage, Arkansas River shiner (Notropis girardi), ferruginous hawk (Buteo regalis), lesser prairie chicken (Tympanuchus pallidicinctus), snowy plover (Charadrius nivosus), 
mountain plover (Charadrius montanus), long-billed curlew (Numenius americanus), interior least tern (Sternula antillarum athalassos), burrowing owl (Athene cunicularia hypugaea), black-tailed prairie dog (Cynomys ludovicianus), bat assemblage, swift fox (Vulpes velox), and mule deer (Odocoileus hemionus).

\section{Assessment Framework}

Management questions form the basis of the REA framework. Core management questions relate to the key ecological attributes and change agents associated with each conservation element. Integrated management questions synthesize the results of the primary core management questions into overall landscape-level ranks for each conservation element. The change agents evaluated vary among conservation elements depending on the core management questions and the availability of data.

Four change agents were evaluated for the Southern Great Plains REA: development (agricultural croplands, urban areas, roads, railroads, and energy and minerals), fire, invasive species, and climate change. We evaluated development for all conservation elements by using either the terrestrial development index or the aquatic development index, which were used to quantify the cumulative landscape-level effects of development. Fire was addressed by compiling recent (1984-2014) fire occurrences for the entire SGP. Because information on fire occurrence is limited, it was difficult to evaluate how fire suppression has altered communities and habitats in the SGP; this issue was a priority management question, but it remains a data gap. Similarly, available information and models on invasive species are limited for most, so we used available habitat suitability models and focused on the potential expansion of woody species in grasslands (honey mesquite [Prosopis glandulosa] and eastern redcedar [Juniperus virginiana]) and riparian areas (Russian olive [Elaeagnus angustifolia] and tamarisk [Tamarix spp.]). To evaluate the potential effects of climate change, we summarized projected changes in precipitation and temperature for several climate change scenarios for the entire SGP. We also used available vegetation models to evaluate potential changes to grassland communities. We did not evaluate climate change for aquatic communities because of the lack of available models.

The methods and results are organized with respect to the management questions for each change agent and conservation element. The information needed to address management questions is organized by chapters, one chapter for all change agents and one chapter for each of the conservation elements. All source and derived datasets used to produce the maps and graphs for REAs are available online at the BLM Landscape Approach Data Portal (https://landscape.blm.gov/geoportal/ catalog/main/home.page).

\section{Management Implications}

REAs summarize information at broad spatial extents and can be used with information at local levels to inform management decisions. For example, REAs can be used as a screening tool to identify potential areas for conservation, restoration, or development projects. Local-level information, including additional surveys and research, can be used to assess conditions not quantified by REAs because of a lack of regional data (such as population sizes of species and occurrence of invasive species). Additionally, REAs can provide assessments of spatially explicit cumulative effects of change agents, especially development. REAs also can augment information from local projects to provide a broader spatial context for evaluating potential effects of proposed actions and alternatives that cannot be determined with local-level information alone. REAs, therefore, contribute to multiscale information necessary for implementing the BLM's landscape approach. 


\section{Chapter 1. Introduction and Overview}

\section{Introduction}

\section{Purpose of the Rapid Ecoregional Assessment}

The overall goal of the Bureau of Land Management (BLM) Rapid Ecoregional Assessments (REAs) is to compile and synthesize regional datasets to facilitate evaluation of the cumulative effects of change agents on priority species and communities. More specifically, the REAs identify important ecosystems and wildlife habitats at broad spatial scales and provide assessments of ecological conditions. The REAs also identify where and to what degree ecological resources are currently at risk from change agents such as development, fire, invasive species, and climate change. They can help managers identify and prioritize potential areas for conservation or restoration, assess cumulative effects as required by the National Environmental Policy Act, and inform landscapelevel planning and management decisions for multiple uses of public lands. The REAs support the BLM landscape approach to resource management by facilitating collaboration and cooperation among all parties interested in regional land and resource management (Carter and others, 2017).

Specific outcomes of the REAs include (1) assessments of current (baseline) conditions for long-term monitoring of conditions and trends at broad spatial extents; (2) assessments of landscape-level intactness of ecological communities, habitats for priority species, and the ecoregion overall; and (3) a predictive capacity for evaluating future risks. They also can identify data gaps and key ecological attributes of communities and habitats, which can inform the development of monitoring strategies for assessing status and trends. The BLM State and field offices and other stakeholders may use this information to facilitate land-use planning and prioritize actions for conservation, restoration, and development, including ascribing bestmanagement practices and usage authorizations. By addressing priority management issues identified by multiple Federal and State agencies working collaboratively, the REAs also foster interagency collaboration and help to ensure that REA results and products are relevant to many stakeholders.

\section{Management Implications}

Ecoregional assessments, such as the REAs, involve spatial analyses conducted at broad spatial scales to quantify landscape-level features of habitats (such as habitat fragmentation and connectivity), identify the most intact areas of ecological communities and wildlife habitats, and quantify both natural and anthropogenic disturbances (Hanser and others, 2011). For example, the REAs can be used as a screening tool to identify potential areas for conservation, restoration, and development projects. The REAs can lead to improved understanding of systems across jurisdictional boundaries and thereby can provide the context needed for assessing broad-scale cumulative effects (Wood and others, 2017). Broad-scale assessments are intended to be used in conjunction with local-level assessments for planning and management activities. Local-level assessments, such as the BLM Assessment, Inventory, and Monitoring program, provide more detailed information on individuals, populations, and habitats than can be determined from ecoregional assessments (Wood and others, 2017). The REAs augment local-level information and provide a broader spatial context for evaluating potential effects of proposed actions and alternatives that cannot be determined with local-level information alone. The REAs, therefore, contribute to multiscale information necessary for a landscape approach.

The BLM's REA program is closely aligned with the U.S. Department of Interior (DOI) strategy for DOI lands, “A Strategy for Improving the Mitigation Policies and Practices of the Department of the Interior" (Clement and others, 2014). A primary objective of the DOI strategy is to shift from projectlevel management to broad-scale, science-based management that helps to avoid, minimize, and compensate for adverse effects on natural resources. Specifically, the REAs address the following key components outlined by the DOI strategy: (1) development of assessment methods that promote consistency in management decisions, (2) identification of ecological characteristics that promote ecosystem resilience in rapidly changing environmental conditions, and (3) fostering collaboration among land-management agencies.

\section{Components of the Rapid Ecoregional Assessment}

\section{Management Questions}

For each REA, BLM land managers and other REA stakeholders identify regionally important management questions that serve as the foundation for the REA process and products. The management questions not only frame the conservation planning and land-management priorities for a given ecoregion, but they also help to ensure that the most relevant datasets are compiled, analyzed, and summarized for the REA. Additionally, the management questions address information needs for developing best-management practices and establishing priorities for conservation, restoration, and development. 


\section{Conservation Elements}

Conservation elements represent ecological communities and species that are of management concern in the region. The emphasis on ecological communities is based on the premise that intact and functioning ecological systems are more resistant and resilient to change agents, including both natural and human stressors (Noss, 1987; Poiani and others, 2000; Parrish and others, 2003). Because it is not feasible to manage or monitor all species individually, the protection of intact ecological communities may serve as a safety net for species not addressed specifically by the REA. Species or species assemblages of management concern not adequately addressed at the community level may be evaluated as conservation elements.

\section{Key Ecological Attributes}

Key ecological attributes can be defined as a limited number of biological characteristics, ecological processes, and interactions with the physical environment that are especially pivotal and influence the long-term persistence of communities and species (Parrish and others, 2003). The attributes can include both the biological and physical environments and the ecological processes that collectively regulate (1) the occurrence, such as distribution and abundance, of communities and habitats; (2) landscape structure, such as size and connectivity of patches; and (3) landscape dynamics, such as natural disturbances including fire and drought.

\section{Change Agents}

The REA identifies and assesses the primary factors, or change agents, that currently affect or are likely to affect the condition of species and communities in the future. Minimally, the change agents to be evaluated for the entire ecoregion include

- development (agriculture, urban areas, roads, dams, diversions, energy and minerals),

- fire,

- invasive species, and

- climate change.

\section{Overview of the Rapid Ecoregional Assessment Process}

The REA is guided by a Management Team, Technical Team, and advisors consisting of BLM managers, partner agencies, and technical specialists representing the ecoregion (hereafter referred to as stakeholders) (Assal and others, 2015). The stakeholders are responsible for ensuring that management needs and conservation priorities are addressed by identifying management questions, conservation elements, and change agents. The stakeholders also provide technical reviews and feedback on all reports and derived datasets.

An REA entails a two-phase process. In the pre-assessment phase, the lists of priority management questions, conservation elements, and change agents are developed and finalized by the stakeholders. The pre-assessment report documents the process and justification used to identify management questions and conservation elements, and it provides background information on all conservation elements (Assal and others, 2015). The assessment phase includes compilation, synthesis, analysis, and documentation of datasets to address management questions and completion of the ecoregional assessment. It also summarizes the management questions that cannot be addressed because of data gaps and limitations.

\section{Southern Great Plains Rapid Ecoregional Assessment}

\section{Project Area}

The BLM partnered with the Great Plains Landscape Conservation Cooperative (GPLCC) to ensure that the results of the Southern Great Plains REA provide information useful in addressing regional management issues identified by a diverse set of stakeholders representing both the REA and the GPLCC. The region covered by the Southern Great Plains REA (hereafter referred to as Southern Great Plains) was expanded from the original project area (Assal and others, 2015) to include the maximum area covered by the GPLCC buffered boundary (Manier, 2011), four Level-III ecoregionsHigh Plains, Central Great Plains, Southwestern Tablelands, and Nebraska Sand Hills (Omernik, 1987) — and an adjacent buffer delineated by fifth-level watersheds intersecting the combined ecoregion boundary (fig. 1-1). The Southern Great Plains (SGP) encompass 961,105 square kilometers $\left(\mathrm{km}^{2}\right)$ (371,085 square miles $\left[\mathrm{mi}^{2}\right]$ ) and include portions of eight states: Colorado, Kansas, Nebraska, New Mexico, Oklahoma, South Dakota, Texas, and Wyoming (fig. 1-1). The area covered by the Southern Great Plains REA is the largest of all the REAs (Bureau of Land Management, 2016).

Most of the surficial land in the SGP is privately owned (fig. 1-2). Collectively, State, Federal, and tribal lands cover less than 9 percent of the SGP. Additionally, the BLM is responsible for managing subsurface rights to the development of mineral resources that are publically held, also known as split estate. The SGP overlaps ten BLM field office jurisdictions: Carlsbad, Casper, Newcastle, Oklahoma, Rawlins, Rio Puerco, Roswell, Royal Gorge, Socorro, and Taos. Most BLM lands within the SGP are located in New Mexico. 


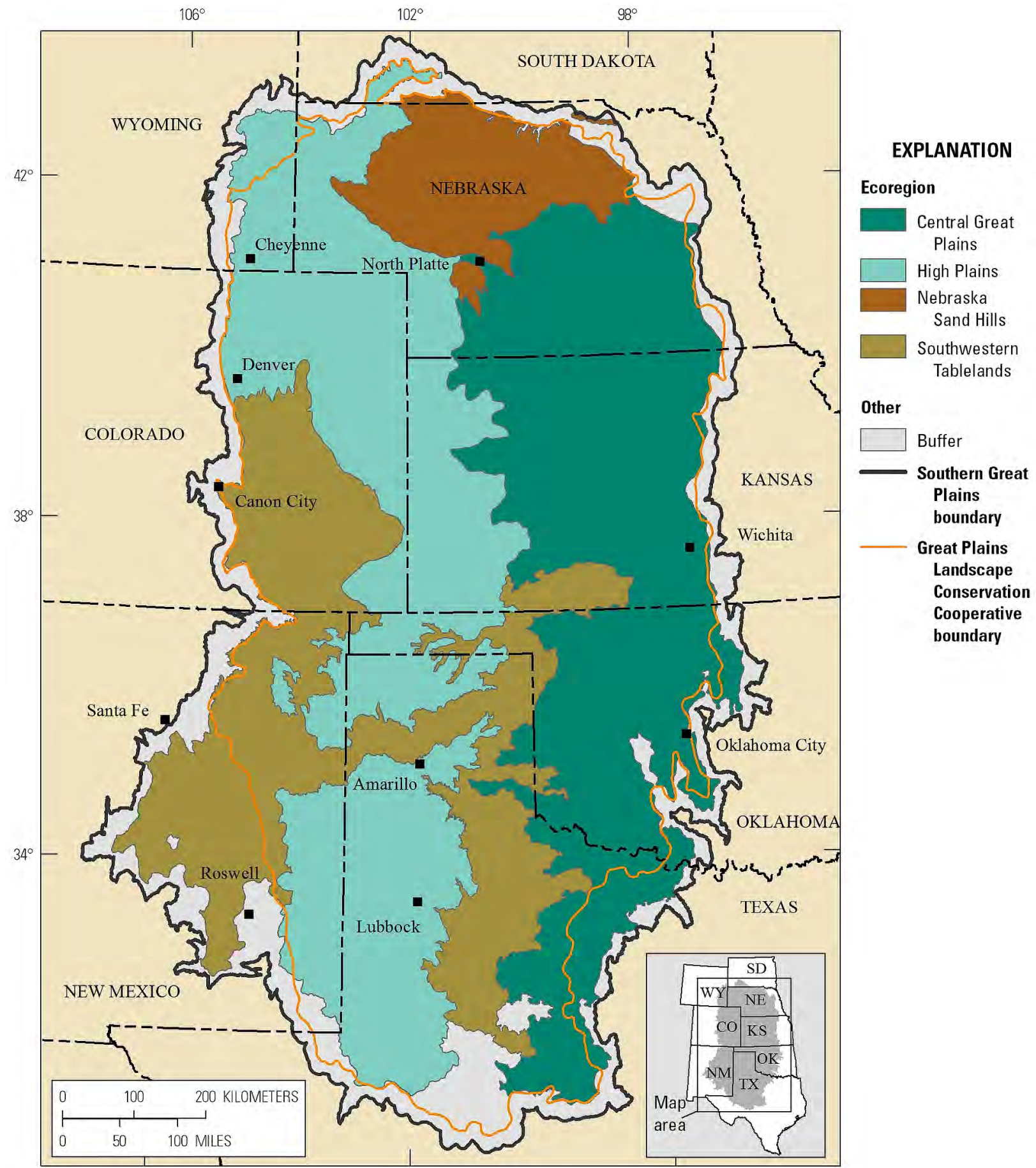

Figure 1-1. Southern Great Plains Rapid Ecoregional Assessment boundary. Level-III ecoregions (Omernik, 1987) and the Great Plains Landscape Conservation Cooperative boundary are shown. 


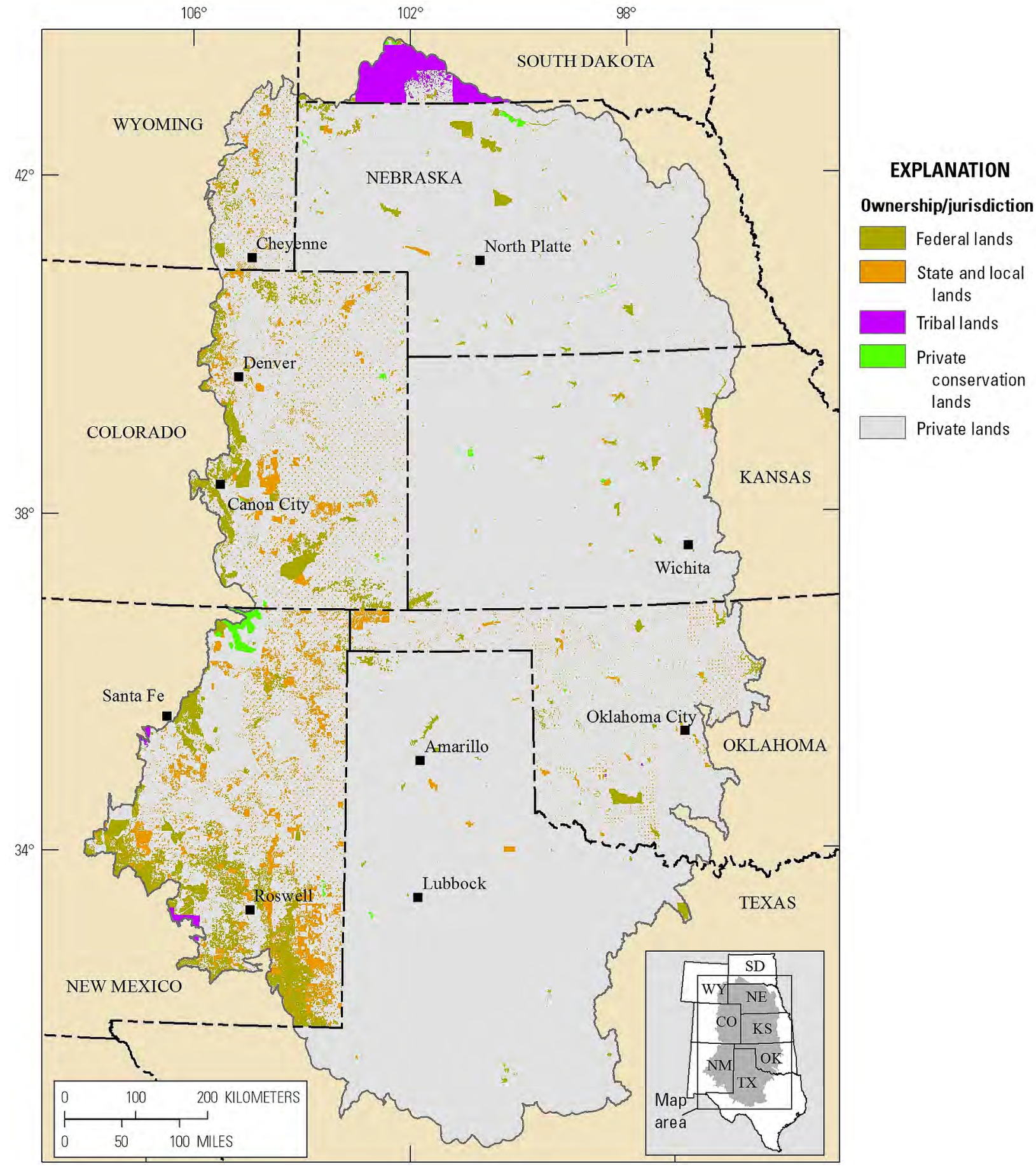

Figure 1-2. Land ownership and jurisdictions for the Southern Great Plains. 


\section{Management Questions}

The management questions developed by the stakeholders were organized into two general themes: core and integrated. Core management questions were tailored for each community and species to evaluate the potential landscapelevel effects of change agents. Integrated management questions synthesize the results of the core management questions to provide an overall evaluation of the landscape-level condition of each conservation element.

\section{Conservation Elements}

\section{Ecological Communities}

Six major ecological communities (hereafter referred to as communities) were selected as conservation elements for the Southern Great Plains REA (table 1-1, fig. 1-3) (Assal and others, 2015): three terrestrial and three aquatic. The terrestrial communities selected are mixed-grass prairie, shortgrass prairie, and sand prairie. Although not initially identified as a conservation element, we also addressed management questions for all grasslands collectively, which include the three grassland conservation elements and the remaining grassland types present in the SGP: tallgrass, northwest mixed-grass, and cool-season bunchgrass prairies; foothill and saline grasslands; and semidesert grassland and shrubland. The aquatic communities selected are riparian and nonplaya wetlands, playa wetlands and saline lakes, and prairie streams and rivers.

Table 1-1. Ecological communities evaluated as conservation elements for the Southern Great Plains Rapid Ecoregional Assessment.

\begin{tabular}{clc}
\hline System & \multicolumn{1}{c}{ Ecological communities $^{\mathbf{1}}$} & $\begin{array}{c}\text { Percent of the } \\
\text { Southern Great Plains } \\
\text { area }^{2}\end{array}$ \\
\hline Terrestrial & Mixed-grass prairie ${ }^{3}$ & 11.2 \\
& Shortgrass prairie & 15.0 \\
& Sand prairie & 12.3 \\
\multirow{2}{*}{ Aquatic } & Other grasslands & 9.7 \\
& Riparian and nonplaya wetlands & 5.2 \\
& Playa wetlands and saline lakes & 0.4 \\
& Prairie streams and rivers & Not applicable $^{5}$ \\
\hline
\end{tabular}

${ }^{1}$ Open water (lakes and reservoirs) and shrubland, woodland, and forest communities were mapped but not evaluated as conservation elements. Open water accounts for 0.7 percent, and shrubland, woodland, and forests account for 10.6 percent of the Southern Great Plains.

${ }^{2}$ Developed lands and cropland account for 34.9 percent of the Southern Great Plains.

${ }^{3}$ Includes midgrass prairie.

${ }^{4}$ Other grasslands include tallgrass, northwest mixed-grass, and cool-season bunchgrass prairies; foothill and saline grasslands; and semidesert grassland and shrubland.

${ }^{5}$ Prairie streams and rivers are linear features and consequently were excluded from areal calculations.

\section{Species and Assemblages}

A preliminary list of priority species and species assemblages was developed during the pre-assessment phase by the stakeholders (Assal and others, 2015). Thirteen species and species assemblages were included in the final list of conservation elements: freshwater mussel assemblage, Arkansas River shiner (Notropis girardi), ferruginous hawk (Buteo regalis), lesser prairie chicken (Tympanuchus pallidicinctus), snowy plover (Charadrius nivosus), mountain plover (Charadrius montanus), long-billed curlew (Numenius americanus), interior least tern (Sternula antillarum athalassos), burrowing owl (Athene cunicularia hypugaea), black-tailed prairie dog (Cynomys ludovicianus), bat assemblage, swift fox (Vulpes velox), and mule deer (Odocoileus hemionus). The ecoregional assessments of species and assemblages will be addressed in the second volume of the REA report.

\section{Change Agents}

We evaluated the four primary change agents required for the REA (development, fire, invasive species, and climate change). Fire and climate (such as drought) are inherent drivers of ecosystem dynamics in the SGP, but fire and climatic regimes may be influenced by human activities (Rowland and Leu, 2011). Human alteration of disturbance regimes, in turn, can lead to habitat loss and other negative effects on species and species assemblages. We refer to natural drivers of landscape dynamics (such as fire and drought) as key ecological attributes and human influences (such as development, altered fire regimes, invasive species, and anthropogenic climate change) on communities and wildlife habitats as change agents. We initially considered grazing as a change agent, based on input from the stakeholders, but limited data availability precluded a regional assessment (see chapter 11, "Data Gaps, Limitations, and Uncertainty"); grazing is best addressed through local-level data (Assal and others, 2015).

\section{Reports and Organization}

\section{Pre-Assessment Report}

The pre-assessment report (Assal and others, 2015) lists the management questions, conservation elements, and change agents selected by the REA stakeholders. The report documents the process used to select these REA components for the SGP. Background information is provided on the key ecological attributes and change agents for each conservation element. The background information includes a narrative, an ecological conceptual model that portrays some of the potential primary interactions and feedbacks among change agents, and tables that summarize potential key ecological attributes 


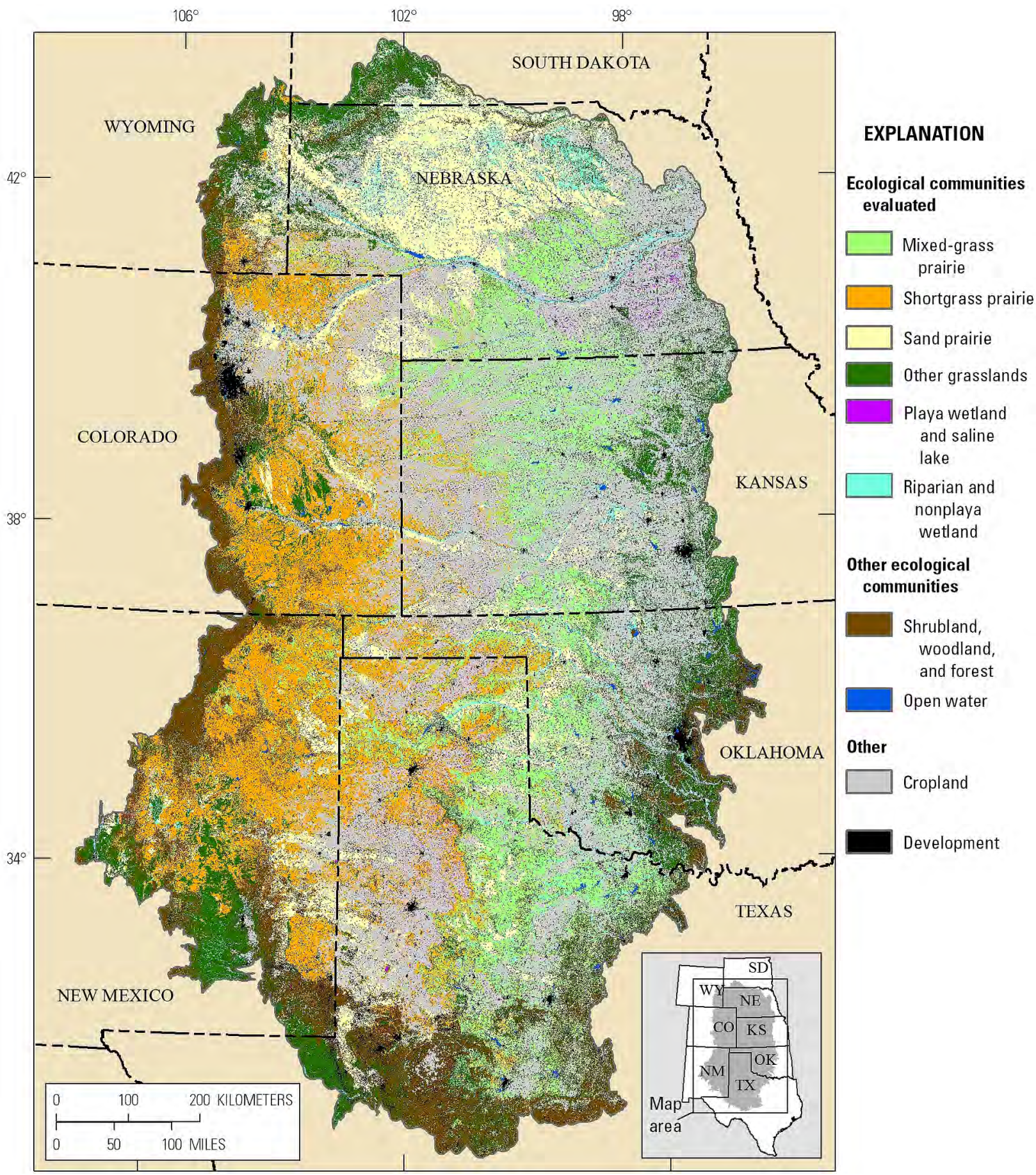

Figure 1-3. Distribution of ecological communities in the Southern Great Plains as well as areas dominated by agricultural cropland and other development. The "other grasslands" community includes tallgrass, northwest mixed-grass, and coolseason bunchgrass prairies; foothill and saline grasslands; and semidesert grassland and shrubland. Sparsely vegetated areas and the community "prairie streams and rivers" are not depicted. Modified from Reese and others (2016). 
and change agents. The conceptual models and tables were intended to highlight factors relevant to the REA and are not an exhaustive synthesis of all factors important to a species or community. Not all key ecological attributes and change agents could be addressed because of data and time limitations (see chapter 11, "Data Gaps, Limitations, and Uncertainty").

\section{Rapid Ecoregional Assessment Reports}

The Southern Great Plains REA is summarized in two volumes. Volume I (this volume) provides background information, methods, and summaries for all the ecological communities evaluated for the REA. Volume II will address the 13 species and species assemblages evaluated for the REA.

\section{Volume I Organization}

Chapter 1, "Introduction and Overview," provides an overview of the BLM's REA program and the required REA components, as well as a summary of the management questions, conservation elements, and change agents for the Southern Great Plains REA. Chapter 2, "Methods Overview," describes the standard methodologies used to assess the core and integrated management questions for conservation elements. This chapter is intended for semitechnical audiences and provides an overview of the approach used for both volumes. Additional technical details are provided in appendix A. Chapter 3, "Change Agents," addresses management questions for the four primary change agents. The results presented in this chapter were used to assess potential effects on conservation elements in both volumes. Chapters 4-10 address the seven ecological communities. These chapters have a consistent format and are organized with respect to the management questions. Each chapter includes the following information.

- A brief narrative overview that highlights information provided in the pre-assessment report.

- Summary tables for each conservation element (additional details on the indicators are provided in chapter 2 and appendix A):

1. The indicators used to evaluate the key ecological attributes.

2. The indicators used to evaluate change agents.

3. The ranking factors used for evaluating overall landscape-level rank.

4. The management questions addressed.

- Maps representing the derived datasets associated with each management question.

- Summary information that highlights a few key findings for each conservation element.
Chapter 11, "Data Gaps, Limitations, and Uncertainty," provides an overview of issues associated with the datasets, analyses, and models used to evaluate change agents and the ecological communities. This chapter also summarizes general management question themes that could not be addressed at the ecoregional level because of data gaps or limitations. Appendix A provides more technical details not included in the methods overview and a list of all source datasets used for the report.

\section{Accessing the Rapid Ecoregional Assessment Datasets}

All source and derived datasets for the REAs are served online at the BLM Landscape Approach Data Portal (https://landscape.blm.gov/geoportal/catalog/main/home.page).

\section{References Cited}

Assal, T.J., Melcher, C.P., and Carr, N.B., eds., 2015, Southern Great Plains Rapid Ecoregional AssessmentPre-assessment report: U.S. Geological Survey Open-File Report 2015-1003, 284 p., accessed September 2015 at https://doi.org/10.3133/ofr20151003.

Bureau of Land Management, 2016, The BLM's landscape approach for managing public lands: Bureau of Land Management website, accessed October 2016 at http:/www.blm.gov/ wo/st/en/prog/more/Landscape_Approach.html.

Carter, S.K., Carr, N.B., Miller, K.H., and Wood, D.J.A., eds., 2017, Multiscale guidance and tools for implementing a landscape approach to resource management in the Bureau of Land Management: U.S. Geological Survey OpenFile Report 2016-1207, 79 p., accessed January 2017 at https://doi.org/10.3133/ofr20161207.

Clement, J.P., Belin, A.d'A., Bean, M.J., Boling, T.A., and Lyons, J.R., 2014, A strategy for improving the mitigation policies and practices of the Department of the Interior-A report to the Secretary of the Interior from the Energy and Climate Change Task Force: U.S. Department of the Interior, Energy and Climate Change Task Force, 25 p., accessed October 12, 2016, at http://www.doi.gov/news/upload/ Mitigation-Report-to-the-Secretary_FINAL_04_08_14.pdf.

Hanser, S.E., Leu, Matthias, Knick, S.T., and Aldridge, C.L., eds., 2011, Sagebrush ecosystem conservation and management-Ecoregional assessment tools and models for the Wyoming Basins: Lawrence, Kans., Allen Press, 409 p. 
Manier, Daniel, 2011, Great Plains Landscape Conservation Cooperative boundary, buffered 10km: U.S. Geological Survey dataset, accessed April 25, 2016, at https:/www.sciencebase. gov/catalog/item/5100263ee4b0ca65fed0d344.

Noss, R.F., 1987, From plant communities to landscapes in conservation inventories - A look at the Nature Conservancy (USA): Biological Conservation, v. 41, p. 11-37.

Omernik, J.M., 1987, Ecoregions of the conterminous United States: Annals of the Association of American Geographers, v. 77, p. 118-125, map scale 1:7,500,000.

Parrish, J.E., Braun, D.P., and Unnasch, R.S., 2003, Are we conserving what we say we are?-Measuring ecological integrity within protected areas: BioScience, v. 53, p. 851-860.

Poiani, K.A., Richter, B.D., Anderson, M.G., and Richter, H.E., 2000, Biodiversity conservation at multiple scalesFunctional sites, landscapes, and networks: BioScience, v. 50, p. 133-146.
Reese, G.C., Manier, D.J., Carr, N.B., Callan, Ramana, Leinwand, I.I.F., Assal, T.J., Burris, Lucy, and Ignizio, D.A., 2016, Estimated historical distribution of grassland communities of the Southern Great Plains: U.S. Geological Survey Open-File Report 2016-1184, 13 p., accessed December 12, 2016, at https://doi.org/10.3133/ofr20161184.

Rowland, M.M., and Leu, Matthias, 2011, Study area description, in Hanser, S.E., Leu, Matthias, Knick, S.T., and Aldridge, C.L., eds, Sagebrush ecosystem conservation and managementEcoregional assessment tools and models for the Wyoming Basins: Lawrence, Kans., Allen Press, p. 10-45.

Wood, J.A., Carter, S.K., Litshert, S.E., and Carr, N.B., 2017, Including broad-scale indicators in multiscale natural resource monitoring and assessment programs in the Bureau of Land Management, chap. 3 of Carter, S.K., Carr, N.B., Miller, K.H., and Wood, D.J.A., eds., Multiscale guidance and tools for implementing a landscape approach to resource management in the Bureau of Land Management: U.S. Geological Survey Open-File Report 2016-1207, p. 15-37, accessed January 2017 at https://doi.org/10.3133/ofr20161207. 


\section{Chapter 2. Methods Overview}

\section{Assessment Framework}

Management questions form the foundation for the assessment framework of the Southern Great Plains Rapid Ecoregional Assessment (REA). Core management questions relate to the key ecological attributes and change agents for each conservation element. The integrated management question synthesizes information from core management questions to provide an overall landscape-level rank for each conservation element. The overall landscape-level ranks can be used to identify the largest intact (least developed) areas across the entire distribution of each conservation element, which is one application of REA datasets (Carr and others, 2017). The chapters for each conservation element provide a list of all the management questions addressed, and the results (maps and graphs) are organized by management question. The management questions can be organized into the following themes.

\section{Core Management Questions}

- Where is the conservation element, and what and where are its key ecological attributes?

- What and where are the change agents that potentially affect the conservation element?

- How do the change agents affect the key ecological attributes of the conservation element?

\section{Integrated Management Question}

- Where are the areas with the highest overall landscapelevel ranks?

\section{Scale of Analysis for Management Questions}

One objective of the REAs is to facilitate evaluation of the cumulative effects of change agents at broad spatial scales (Carter and others, 2017). Scale is an important consideration for conducting REAs because the resolution or precision of the source data, the resolution of reporting units, and the spatial extent over which data are analyzed may affect the results and conclusions. Additionally, a single scale may be sufficient to summarize information for a particular management question, but multiple scales may be needed to summarize patterns that vary across spatial scales (Carr and others, 2017; Carter and others, 2017). We selected analysis scales based on Carr and Melcher (2015) and Carr and others (2017).
We defined three nested levels for evaluating conservation elements in the REA. For terrestrial conservation elements, the three levels are the native resolution of the datasets, landscape, and regional. The native resolution of the source datasets was 900 square meters $(1,076$ square yards) (LANDFIRE, 2012; Reese and others, 2016). Landscape level corresponds to scales used for most analyses of terrestrial conservation elements (for example, moving windows with a 2.5-kilometer [km; 1.55-miles (mi)] radius), and the regional level corresponds to patterns that span the entire Southern Great Plains (SGP) (see chapter 1, "Introduction and Overview," for a description of the SGP boundary). For aquatic conservation elements, we used three nested watershed levels: catchment, sixth-level watershed, and fifth-level watershed (U.S. Environmental Protection Agency and U.S. Geological Survey, 2012; U.S. Geological Survey and U.S. Department of Agriculture, Natural Resources Conservation Service, 2013). Core management questions were addressed using the native resolution of the data and summarized using $2.5-\mathrm{km}$ moving windows or sixthlevel watersheds. Integrated management questions were addressed by creating relative ranks for the entire SGP using 5-km (3.1-mi) moving windows for terrestrial conservation elements or fifth-level watersheds for aquatic conservation elements. A description of the methods, including a description of the analysis scales, is organized by each management question in the "Management Questions" section.

\section{Baseline Distributions for Evaluating Change Agents}

To evaluate the current conditions of the SGP, we mapped the baseline distribution of each conservation element. Baseline distributions for terrestrial (grassland) and aquatic communities were determined differently depending on the availability of data on reference conditions (prior to EuroAmerican settlement). For grassland communities, we used the estimated distribution of historical grasslands (Reese and others, 2016) as reference conditions and for deriving the baseline distribution of grasslands in the SGP. In the case of aquatic communities, the lack of regional information on reference conditions limits our ability to fully quantify the direct effects of past alteration. Creation and modification of wetlands by agricultural activities further confounds this problem. The methods used to map baseline distributions are described in the "Management Questions" section. 
The baseline distribution of each conservation element was used to evaluate the potential effects of change agents. The change agents evaluated varied among conservation elements depending on the core management questions and the availability of data and published models.

- Development.-We evaluated the broad-scale cumulative effects of existing development for all conservation elements by using the terrestrial development index and the aquatic development index.

- Fire.-Recent fire occurrence (1984-2014) was evaluated for the entire SGP and summarized by ecological community.

- Invasive species. - Available information and models are limited for most invasive species, so we focused on the presence of two woody species in grasslands (honey mesquite [Prosopis glandulosa] and eastern redcedar [Juniperus virginiana]) and the presence of and habitat suitability for two woody species in riparian areas (Russian olive [Elaeagnus angustifolia] and tamarisk [Tamarix spp.]).

- Climate change.-We summarized projected changes in temperature and precipitation for climate change scenarios for the entire SGP and the potential effects on grassland communities.
The management questions and results for the change agents across the entire SGP are summarized in chapter 3, "Change Agents." The methods used to quantify the change agents are described for the "Management Questions" section. The data sources used for all change agents are summarized in appendix A (table $\mathrm{A}-1)$.

\section{Management Questions}

\section{Core Management Questions for Evaluating Current and Future Change Agents}

Where does existing development pose the greatest threats to terrestrial communities, and where are the large, relatively undeveloped areas? How do development levels vary by development types in terrestrial communities?

The terrestrial development index (TDI) quantifies the cumulative effects of development (agricultural croplands, urban areas, transportation [roads, railroads], and energy and minerals) at the landscape level. We quantified each development type (fig. 2-1) by using a common metric, the area

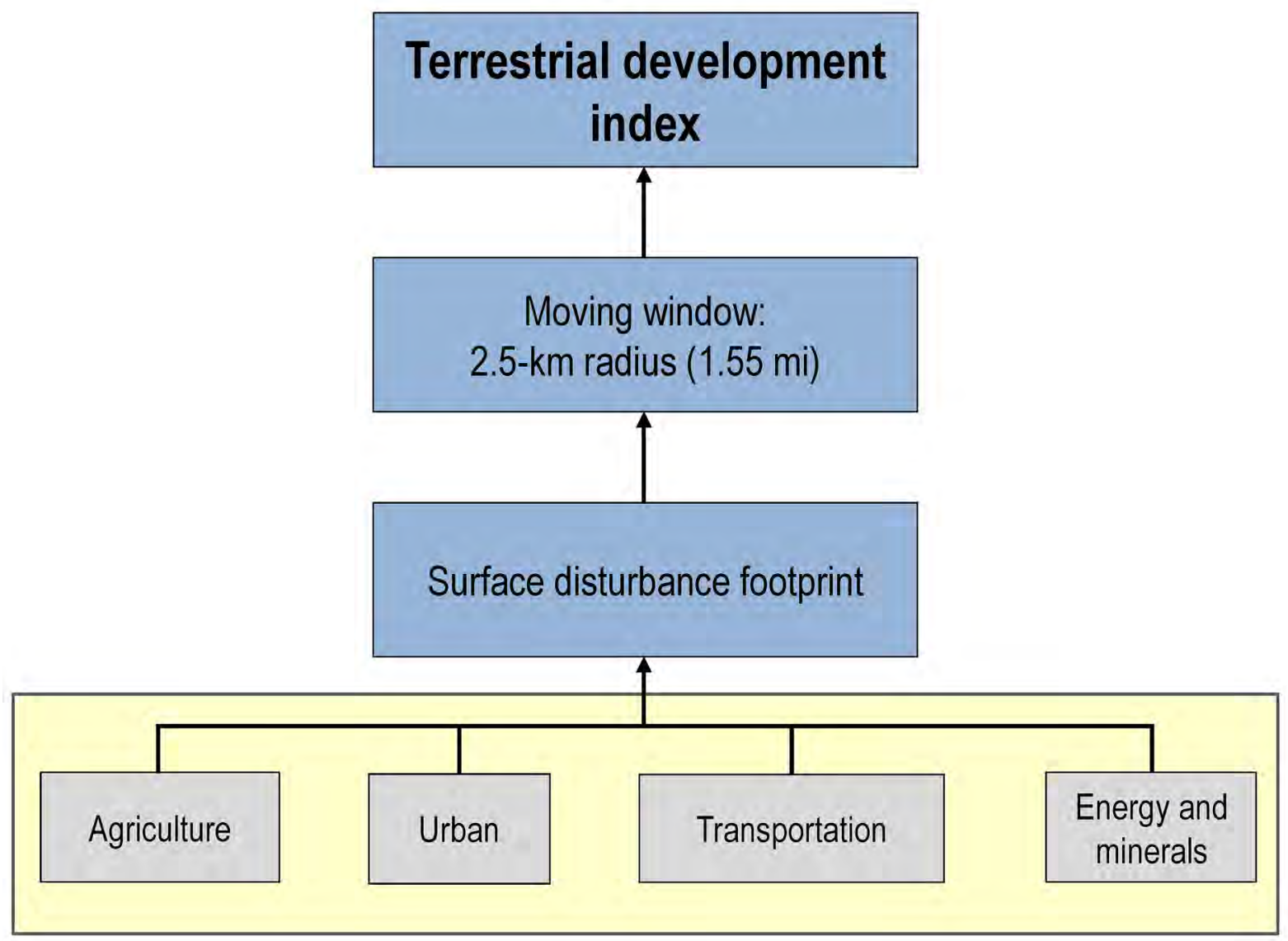

Figure 2-1. Overview of the process for deriving the terrestrial development index for the Southern Great Plains Rapid Ecoregional Assessment. (km, kilometer; mi, mile) 
of the surface disturbance footprint (hereafter referred to as footprint), and combined individual development types into an overall footprint area. The TDI was derived from the percent of the overall footprint area in a circular moving window with a radius of $2.5 \mathrm{~km}(1.55 \mathrm{mi})$. The size of the moving window was selected to capture the cumulative effects of development that cannot be determined at much smaller scales (for additional justification for analysis scales and methods, see Carr and Melcher [2015] and Carr and others [2017]).

TDI scores range from 0 to 100 percent and were divided into seven classes for visualization and analysis purposes (figs. 3-1 and 3-2). To identify areas with the least development, we defined relatively undeveloped areas as having a TDI score $\leq 2$ percent, which represents approximately 10 to 30 percent of each grassland community. See the "Terrestrial Development Index" section in appendix A for additional detail on the methods used to calculate the TDI and select the breakpoints between classes. The continuous TDI scores can be partitioned into alternative classes to address other management questions. We also calculated TDI by development type (figs. 3-3 and 3-4).
Where does existing development pose the greatest threats to aquatic communities, and where are the large, relatively undeveloped areas? How do development levels vary by development type in aquatic communities?

We calculated an overall aquatic development index (ADI) with inputs used for calculating the TDI and additional aquatic development variables (fig. 2-2, table A-1). The ADI is adapted from Annis and others (2010), Fore and others (2014), and Carr and Melcher (2015). We used the footprint from agricultural croplands, urban areas, transportation (roads, railroads), and energy and minerals development as input variables that can affect sedimentation rate, flow regime, and water quality (table A-2). The additional input variables relate to water use and flow (dams, diversions, and road and railroad stream crossings) (table A-1), but they can also affect sedimentation rate and riparian vegetation occurrence (table A-2). All development variables were quantified at the local catchment level (local $\mathrm{ADI}$, fig. $\mathrm{A}-3 A$ ) and by the upstream contributing area for each catchment (upstream ADI, fig. A-3B). Catchments were

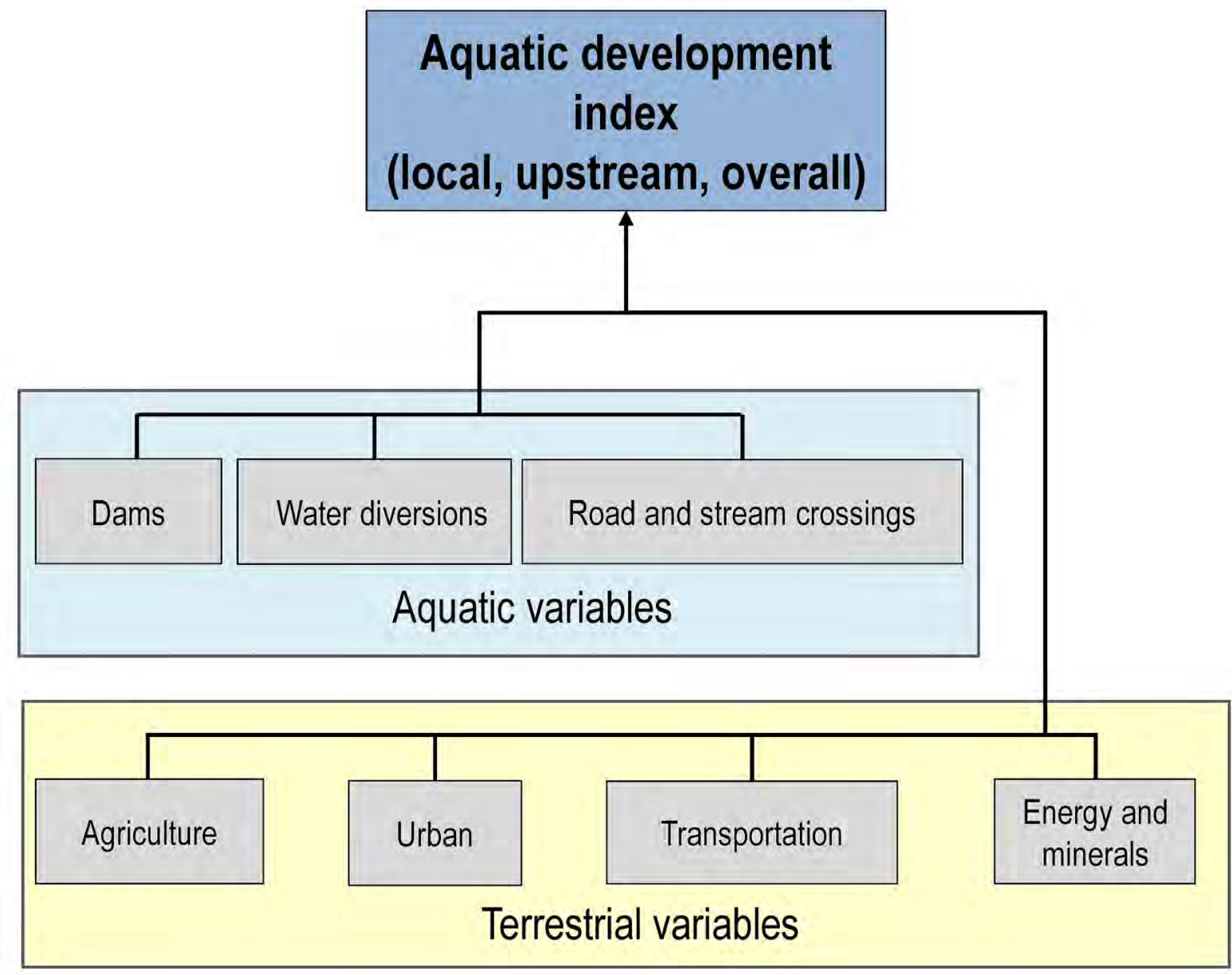

Figure 2-2. Overview of the process for deriving the aquatic development index for the Southern Great Plains Rapid Ecoregional Assessment. The aquatic development index (ADI) is quantified for the local catchment (local $A D I$ ), the upstream contributing area (upstream ADI), and the overall ADI (combined local and upstream ADI). 
defined according to the National Hydrography Dataset Plus, version 2.1 (U.S. Environmental Protection Agency and U.S. Geological Survey, 2012).

ADI scores range from 0 to 100 . Scores less than 50 were divided into six classes using equal breakpoints, and scores greater than 50 were combined into a seventh class (see Carr and Melcher [2015] for justification for ADI classes). To identify areas with the least development, we define relatively undeveloped areas as having ADI and local ADI scores $\leq 20$. We summarized ADI for catchments (native resolution of the ADI) and averaged the catchment-level ADI scores by sixth-level watershed (fig. 3-5). ADI was also calculated by development type (fig. 3-7).

What is the size and distribution of fires since 1984 overall and by ecological community?

Because information on fire occurrence is limited, it is difficult to evaluate how fire suppression has altered communities and habitats in the SGP, which was a priority management question (see Assal and others [2015] for additional details on the historical fire regimes). To evaluate fire, we compiled data on recent fire occurrences (1984-2014) for the entire REA project area (table A-1). Fire perimeters that extended beyond the project boundary were included. We summarized the total area burned annually (figs. 3-8 and 3-9) and the total area burned for each ecological community (table 3-3).

\section{What is the distribution of potentially altered vegetation?}

We mapped the potential for the presence of altered vegetation using LANDFIRE (2012) Existing Vegetation Types (EVTs) (table A-5) that represent invasive herbaceous plants, urban vegetation, pasturelands, and ruderal vegetation (composition altered by human activities) (fig. 3-10).

How do contemporary patterns of temperature and precipitation compare to that projected for relatively hot-dry and warm-wet climate scenarios in 2030 and 2060?

To evaluate the potential for changes in mean annual temperature and precipitation, we used output from general circulation models to compare contemporary climatic conditions (1981-2010) to relatively hot-dry and warm-wet climate scenarios (figs. 3-11 and 3-12). Contemporary climatic conditions (1981-2010) were derived from monthly data (Maurer and others, 2002). We used mean annual temperature and precipitation from general circulation models corresponding to a hot-dry scenario (ACCESS1.0 [table A-1]) and a warm-wet scenario (CESM1(BGC) [table A-1]) (figs. 3-11 and 3-12). Two future time periods were evaluated: 2016-2045 represented by 2030 and 2046-2075 represented by 2060 .

\section{Core Management Questions for Evaluating Terrestrial Communities}

What are the baseline distributions of grassland communities, and where have they been altered by development?
We used the estimated historical distribution of grasslands (hereafter referred to as historical grasslands) to map the grassland communities prior to conversion by development (Callan and others, 2016; Reese and others, 2016). Historical grassland cells were classified as "converted" using the footprint from the terrestrial development index. We removed historical grassland cells currently classified as a baseline aquatic community. In addition, we used LANDFIRE EVT to update the historical grassland map (see "Terrestrial Community Baseline Distribution Mapping" section in appendix A).

We mapped each of the three grassland conservation elements individually (mixed-grass, fig. 5-1; shortgrass, fig. 6-1; and sand prairies, fig. 7-1). To address management questions that were most appropriate for all grasslands in the SGP, we combined all grassland communities: mixed-grass, shortgrass, sand, tallgrass, northwest mixed-grass, and cool-season bunchgrass prairies; foothill and saline grasslands; and semidesert grassland and shrubland.

Where does existing development pose the greatest threat to grassland communities, and where are the large, relatively undeveloped areas?

To evaluate the cumulative effects of development, we overlaid the TDI (fig. 3-1) on the baseline distribution map for each grassland community (figs. 4-3, 5-2, 6-2, 7-3).

Where has development fragmented grassland communities?

We evaluated the fragmenting effects of development for each grassland community in two ways (figs. $4-5,5-4,6-4$, 7-5). First, we compared patch sizes of the historical and baseline distributions. Second, we evaluated patch sizes of relatively undeveloped areas. Because the estimated distribution of historical grasslands is highly connected across the SGP (fig. 4-1), the grassland patch-size map displays patch-size distributions for the baseline distribution compared to relatively undeveloped grasslands (fig. 4-6). In contrast, maps for the other three grassland types display patch sizes for the estimated historical and baseline distributions (figs. 5-5, 6-5, 7-6). Patch sizes for historical, baseline, and relatively undeveloped conditions are summarized graphically for each community (figs. $5-4,6-4,7-5$ ).

Where are potential areas of honey mesquite and eastern redcedar expansion?

Prior to EuroAmerican settlement, honey mesquite occurred as far north as Oklahoma but has since expanded, especially in the semidesert grassland and shrubland community. The distribution of eastern redcedar has been increasing in the SGP. To map the potential distribution of honey mesquite and eastern redcedar (fig. 4-7), we compiled occurrence data (table A-1) and included all LANDFIRE EVTs that indicated the possible occurrence of mesquite (table A-5).

Where are grasslands vulnerable to projected climate change?

To evaluate the potential effects of climate change on grasslands, we used available models of bioclimatic conditions (also called bioclimatic envelopes) suitable for Great 
Plains grassland communities (excluding semidesert grassland and shrubland) developed by Rehfeldt and others (2012). An ensemble bioclimatic model derived using three bioclimatic models (each using two greenhouse gas emissions scenarios) (Rehfeldt and other, 2012) was used to map the potential distribution of grasslands for two time periods: 2026-2035 (2030) and 2056-2065 (2060). The resulting bioclimatic envelope maps show the potential for change and indicate how the bioclimatic conditions conducive for grasslands could shift; thus, they indicate potential vulnerabilities for the climate scenarios evaluated (fig. 4-8). The modeled bioclimatic envelope for contemporary climatic conditions generally corresponds to the distribution of grassland communities in the SGP (excluding semidesert grassland and shrubland), but it shows a much broader spatial representation of areas where grasslands could potentially occur than was observed for the baseline distribution. Local conditions, biotic interactions, and legacies of past disturbance, among other factors, can affect the distribution of grasslands within otherwise potentially suitable bioclimatic conditions.

\section{Core Management Questions for Evaluating Aquatic Communities}

\section{What is the baseline distribution of the aquatic communities?}

Distribution maps for aquatic communities were derived from LANDFIRE EVTs or published datasets (table A-4; figs. 8-1, 9-1, 9-2, 10-1). All aquatic community maps were summarized by sixth-level watersheds (also referred to as 12-digit hydrologic units in the National Watershed Boundary Dataset [U.S. Geological Survey and U.S. Department of Agriculture, Natural Resources Conservation Service, 2013]) (figs. 8-2, 9-3, 10-2, 10-3). The area of riparian and nonplaya wetlands (hereafter referred to as wetlands) and of playa wetlands (hereafter referred to as playas) and saline lakes was summarized as percentage of sixth-level watershed (total area of the community type divided by watershed area). We summarized the total stream length by sixth-level watershed for perennial and intermittent stream lengths separately.

Where does existing development pose the greatest threat to aquatic communities, and where are the large, relatively undeveloped areas?

We assessed development levels for riparian and nonplaya wetlands and for prairie streams and rivers (hereafter referred to as prairie streams) based on the ADI score. For riparian and nonplaya wetlands, area-weighted scores were derived using the catchment ADI score and the total area of the aquatic community in that catchment. For streams, we used stream-length weighted scores (figs. 10-4, 10-5). The weighted ADI score was used to calculate the mean ADI score by community for each sixth-level watershed containing the community (fig. 8-3).
For playas and saline lakes, we used only the local ADI scores to assess development levels and did not include the upstream ADI component because these systems are primarily fed by precipitation and runoff from the surrounding catchment. Upstream catchment inputs are assumed to have relatively little, if any, effect on the local catchment. We calculated a local ADI score for each playa and saline lake, which was then used to calculate the area-weighted mean local ADI score for each sixth-level watershed (figs. 10-4, 10-5).

\section{Where has development fragmented aquatic communities?}

The calculation of patch sizes was determined differently for each aquatic community (figs. 8-5, 9-7A, 9-7B, 10-7). Patch size for riparian and nonplaya wetlands was calculated by using the area of contiguous cells of either riparian or nonplaya wetlands. Mapped area (defined by polygons) was used to calculate playa and saline lake patch size. For perennial prairie streams, patch size was calculated by stream-segment length for both the baseline distribution and relatively undeveloped conditions. Differences in stream-segment length between the baseline distribution and relatively undeveloped areas were used as an index of fragmentation. For perennial streams, the aggregate count of dams and potential barriers (points of diversion and road and railroad stream crossings) (table A-1) was summarized by sixth-level watershed to evaluate where development may have altered flow regime, fragmented streams, and decreased structural connectivity (fig. 10-8).

Where are Russian olive and tamarisk present, and where are riparian areas suitable for their expansion?

We compiled and mapped occurrences of Russian olive and tamarisk (table A-1; figs. 8-6, 8-7). We used available models of habitat suitability for Russian olive and tamarisk developed for the western United States to identify areas of suitable habitat (Jarnevich and others, 2011; Jarnevich and Reynolds, 2011; Carr and Melcher, 2015). See the "Russian Olive and Tamarisk" section in appendix A for additional details.

\section{Integrated Management Question for Evaluating Terrestrial and Aquatic Communities}

\section{Where are the areas with the highest overall landscape- level ranks?}

The integrated management questions synthesize the results from core management questions. We used the amount and distribution of each conservation element, which is a key ecological attribute, for summarizing landscape-level area (or density for streams). We used the TDI or ADI for each conservation element, which is a change agent, for summarizing landscape-level development. These two landscape-level ranking factors were used because they were consistently available for all conservation elements. Landscape-level area (density) and landscape-level development were ranked by conservation element for the entire SGP, and these ranks were combined into an overall landscape-level rank (fig. 2-3). 
We used the baseline distributions of each conservation element to summarize landscape-level area (density). For terrestrial conservation elements, we summarized landscape-level area as a percentage of a moving window with a $5-\mathrm{km}$ (3.1-mi) radius. For riparian and nonplaya wetlands and playas and saline lakes, we summarized landscape-level area as a percentage of fifth-level watershed area. For streams, we calculated landscapelevel density using stream length divided by watershed area, also referred to as drainage density (Horton, 1932).

To calculate landscape-level development using TDI or ADI, we used the same methods described for the core management questions, but the scores were summarized using larger analysis units. For terrestrial communities, we summarized mean TDI using a moving window with a 5-km (3.1-mi) radius. For aquatic communities, we summarized ADI (or local ADI for playas and saline lakes) by fifth-level watershed.

The ranking breakpoints for landscape-level area (density) for terrestrial and aquatic communities were determined by partitioning the data into three equal subsets (with adjustments for highly skewed distributions; see appendix A). The ranking breakpoints for TDI and ADI scores were standardized and applied consistently for each community (TDI: $0-2,>2-10,>10$; local ADI and ADI: 0-20,>20-40,>40). Because the ranking breakpoints for landscape-level area are calculated for each conservation element, the ranks are not equivalent across conservation elements. Rather, ranks are relative and provide a synthetic regional summary of the geospatial datasets developed to address core management questions for each conservation element.
The highest overall landscape-level rank represents locations with the largest area (or density) of the conservation element and the lowest development levels. The lowest landscape-level rank represents locations with the smallest area (or density) of the conservation element and the highest development levels. Additional possible combinations were used to represent a gradient in landscape-level ranks (fig. 2-3). Because rankings are sensitive to the input data and criteria used to develop the ranking thresholds, they are not intended as standalone maps. However, they are useful for comparing rankings among areas in the SGP when used in conjunction with more detailed geospatial data summarized for core management questions.

\section{Summary}

The overall process model used to conduct the assessments of conservation elements is summarized in figure 2-4. Core and integrated management questions form the foundation for the assessment framework. Core management questions address the key ecological attributes and change agents that were evaluated for each conservation element. Integrated management questions synthesize information from the primary core management questions, focusing on the landscape-level area (or density) of the conservation element and landscape-level development.

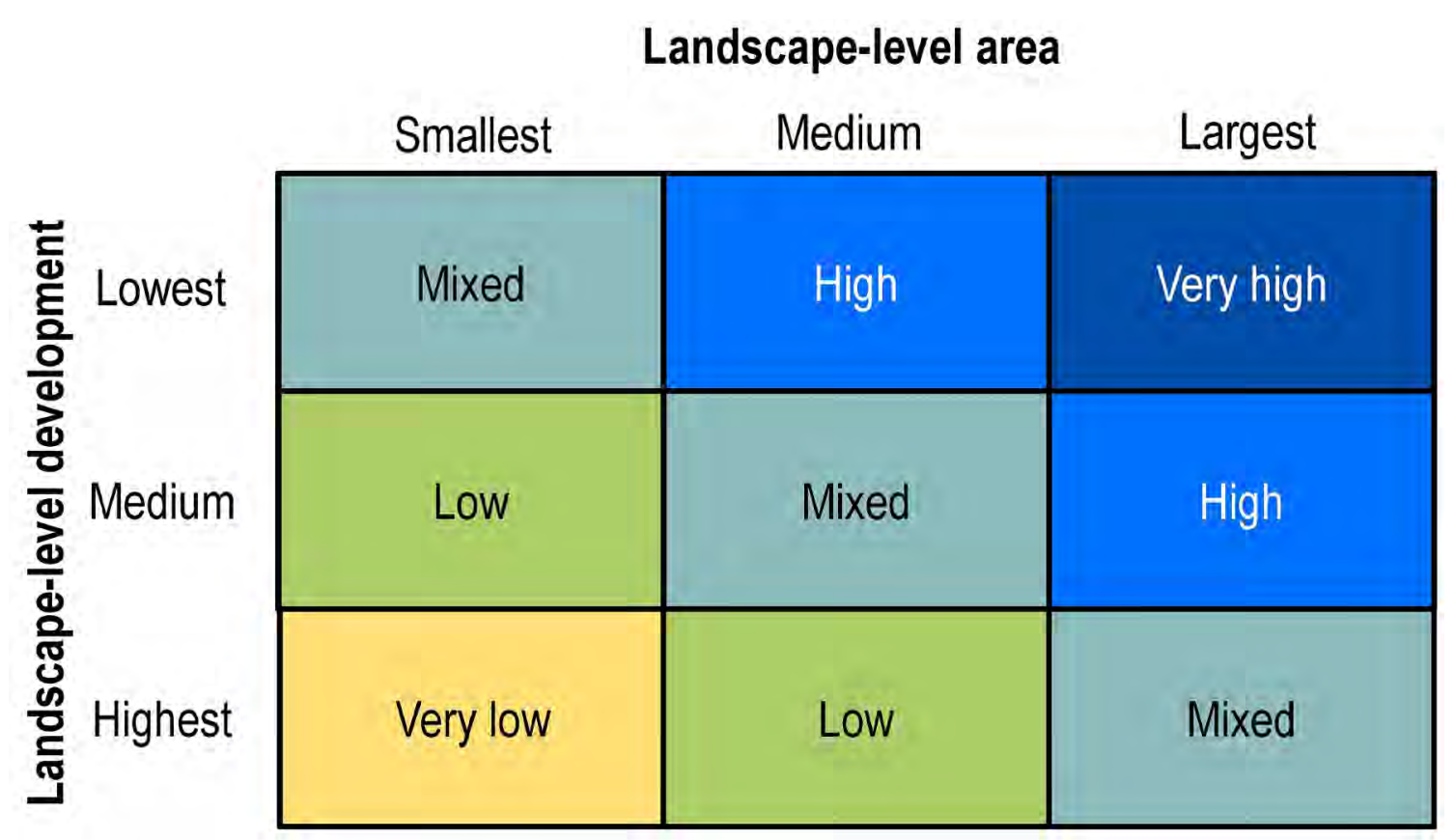

Figure 2-3. Overall landscape-level ranks for the Southern Great Plains Rapid Ecoregional Assessment. The "very high" landscape rank represents locations with the largest landscape-level area and lowest landscapelevel development. The "very low" landscape rank represents locations with the smallest landscape-level area and highest landscape-level development. Other possible combinations of ranks are shown. 


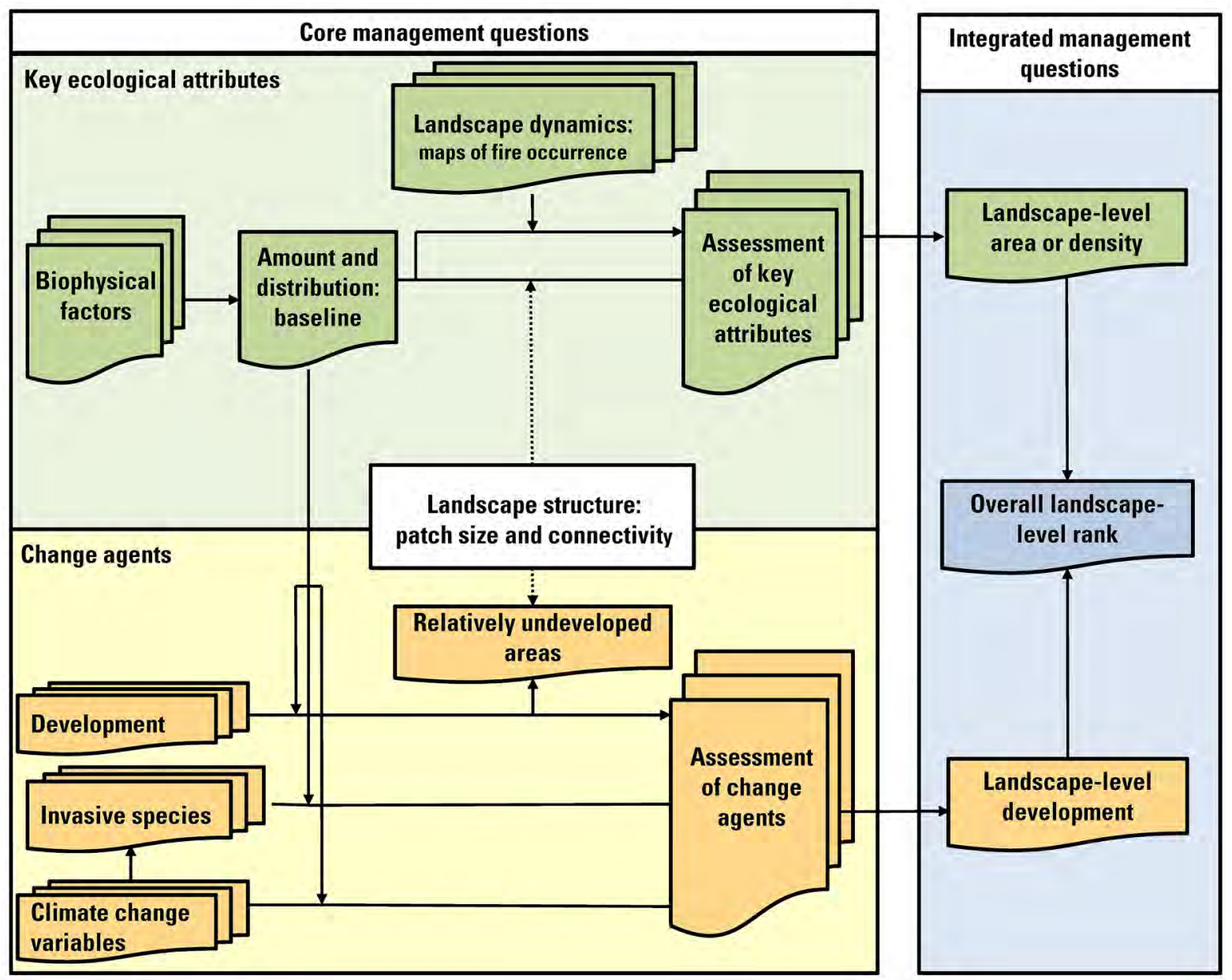

Figure 2-4. Overview of the process used to address the core and integrated management questions for each conservation element. Dotted lines indicate analyses (white boxes) performed on derived maps.

\section{References Cited}

Annis, G.M., Sowa, S.P., Diamond, D.D., Combes, M.D., Doisy, K.E., Garringer, A.J., and Hanberry, Phillip, 2010, Developing synoptic human threat indices for assessing the ecological integrity of freshwater ecosystems in EPA Region 7, final report: Columbia, Mo., University of Missouri, School of Natural Resources, $192 \mathrm{p}$.

Assal, T.J., Melcher, C.P., and Carr, N.B., eds., 2015, Southern Great Plains Rapid Ecoregional Assessment-Pre-assessment report: U.S. Geological Survey Open-File Report 2015-1003, 284 p., accessed September 2015 at https://doi.org/10.3133/ ofr20151003.

Callan, Ramana, Leinwand, I.I.F., Reese, G.C., Assal, T.J., Manier, D.J., Carr, N.B., Burris, Lucy, and Ignizio, D.A., 2016, Estimated historical distribution of grassland communities of the Southern Great Plains: U.S. Geological Survey data release, accessed November 14, 2016, at https://doi.org/10.5066/ F71Z42J3.
Carr, N.B., Leinwand, I.F., and Wood, D.J.A., 2017, A multiscale index of landscape intactness for management of public lands, chap. 5 of Carter, S.K., Carr, N.B., Miller, K.H., and Wood, D.J.A., eds., Multiscale guidance and tools for implementing a landscape approach to resource management in the Bureau of Land Management: U.S. Geological Survey Open-File Report 2016-1207, p. 55-74, accessed January 2017 at https://doi.org/10.3133/ofr20161207.

Carr, N.B., and Melcher, C.P., eds., 2015, Wyoming Basin Rapid Ecoregional Assessment: U.S. Geological Survey Open-File Report 2015-1155, 896 p., accessed September 2015 at https://doi.org/10.3133/ofr20151155.

Carter, S.K., Carr, N.B., Miller, K.H., and Wood, D.J.A., eds., 2017, Multiscale guidance and tools for implementing a landscape approach to resource management in the Bureau of Land Management: U.S. Geological Survey OpenFile Report 2016-1207, 79 p., accessed January 2017 at https://doi.org/10.3133/ofr20161207. 
Fore, J.D., Sowa, S.P., Galat, D.L., Annis, G.M., Diamond, D.D., and Rewa, Charles, 2014, Riverine threat indices to assess watershed condition and identify primary management capacity of agriculture natural resource management agencies: Environmental Management, v. 53, p. 567-582.

Horton, R.E., 1932, Drainage-basin characteristics: Transactions American Geophysical Union, v. 13, p. 350-361.

Jarnevich, C.S., Evangelista, Paul, Stohlgren, T.J., and Morisette, Jeffery, 2011, Improving national-scale invasion maps-Tamarisk in the western United States: Western North American Naturalist, v. 71, p. 164-175.

Jarnevich, C.S., and Reynolds, L.V., 2011, Challenges of predicting the potential distribution of a slow-spreading invader-A habitat suitability map for an invasive riparian tree: Biological Invasions, v. 13, p. 153-163.

LANDFIRE, 2012, Existing Vegetation Type (ver. 1.3.0): U.S. Forest Service and U.S. Department of the Interior, accessed December 29, 2014, at https://landfire.gov/ NationalProductDescriptions21.php.

Maurer, E.P., Wood, A.W., Adam, J.C., Lettenmaier, D.P., and Nijssen, B., 2002, A long-term hydrologically based dataset of land surface fluxes and states for the conterminous United States: Journal of Climate, v. 15, no. 22, p. 3237-3251.
Reese, G.C., Manier, D.J., Carr, N.B., Callan, Ramana, Leinwand, I.I.F., Assal, T.J., Burris, Lucy, and Ignizio, D.A., 2016, Estimated historical distribution of grassland communities of the Southern Great Plains: U.S. Geological Survey Open-File Report 2016-1184, 13 p., accessed December 12, 2016, at https://doi.org/10.3133/ofr20161184.

Rehfeldt, G.E., Crookston, N.L., Sáenz-Romero, Cuauhtémoc, and Campbell, E.M., 2012, North American vegetation model for land-use planning in a changing climate-A solution to large classification problems: Ecological Applications, v. 22, no. 1, p. 119-141.

U.S. Environmental Protection Agency and U.S. Geological Survey, 2012, NHDPlus version 2.1 [vector digital data, raster digital data, tabular digital data]: U.S. Environmental Protection Agency and U.S. Geological Survey, accessed January 25, 2015, at http://www.horizon-systems.com/ NHDPlus/NHDPlusV2_data.php.

U.S. Geological Survey and U.S. Department of Agriculture, Natural Resources Conservation Service, 2013, Federal standards and procedures for the National Watershed Boundary Dataset (WBD) (4th ed.): U.S. Geological Survey Techniques and Methods, book 11, chap. A3, 63 p., accessed January 18, 2017, at http://pubs.usgs.gov/tm/ tm11a3/. 


\section{Chapter 3. Change Agents}

\section{Introduction}

The Homestead Act of 1862 encouraged 1.5 million people to settle in the Great Plains. Large tracts of native grassland were subsequently converted to cultivated agriculture in the eastern Great Plains and used as pasturelands in the western Great Plains (Samson and others, 2004). Since the 1950s, the total population has increased despite declines in the rural areas (Wilson, 2009). Today the major population centers are found along the eastern and western boundaries of the region.

In the Great Plains, the total area in cultivation and pasturelands peaked during the mid-20th century and remained relatively stable through the 1990s (Gutman and others, 2005). By the 1940s, advanced pumping technology and the availability of rural electric power encouraged the use of groundwater for crop irrigation (Hart, 2008). The largest source of groundwater in the region is the Ogallala aquifer, which has been severely depleted by extensive pumping for irrigation (Nativ and Smith, 1987). Agriculture remains the dominant land use in the Southern Great Plains (SGP). Livestock grazing is the main agricultural activity of the shortgrass prairie, whereas cultivation of wheat is the dominant land use in areas that were historically mixed-grass prairie (Hart, 2008; National Park Service, 2008). Minerals and energy extraction are important economic drivers in the region (National Park Service, 2008), and wind development has accelerated in recent years. Additional background information can be found in the SGP pre-assessment report (Assal and others, 2015).

\section{Change Agents and Management Questions}

The change agents evaluated are development (agricultural croplands, urban areas, transportation, and energy and minerals), fire, invasive species, and climate change (table 3-1). In this chapter, we summarize the overall patterns and general effects of each change agent across the entire SGP. The core management questions are listed in table 3-2. Additional management questions for each change agent are addressed by ecological community in chapters $4-10$.

Table 3-1. Change agents and associated indicators used to address management questions for the Southern Great Plains Rapid Ecoregional Assessment.

\begin{tabular}{|c|c|c|}
\hline Change agents & Variables & Indicators $^{1}$ \\
\hline Fire & Fire occurrence & Fire size overall and by community types \\
\hline \multirow[t]{2}{*}{ Invasive species } & Potentially altered vegetation & $\begin{array}{l}\text { Existing Vegetation Types (LANDFIRE, 2012a) indicating potential for } \\
\text { altered species composition. }\end{array}$ \\
\hline & Occurrence and potential for woody species expansion & See chapter 4, "Grasslands"; chapter 8, "Riparian and Nonplaya Wetlands" \\
\hline Climate change & $\begin{array}{l}\text { Potential grassland change as a function of projected } \\
\text { temperature and precipitation }\end{array}$ & See chapter 4 , "Grasslands" \\
\hline
\end{tabular}

${ }^{1}$ See chapter 2, "Methods Overview," and appendix A for methods and datasets used.

Table 3-2. Management questions addressed for change agents for the Southern Great Plains Rapid Ecoregional Assessment.

\begin{tabular}{lc}
\hline \multicolumn{1}{c}{ Core management questions } & Results \\
\hline $\begin{array}{l}\text { Where does existing development pose the greatest threats to terrestrial communities, and where are the } \\
\text { large, relatively undeveloped areas? }\end{array}$ & Figures 3-1 and 3-2 \\
How do development levels vary by development types in terrestrial communities? & Figures 3-3 and 3-4 \\
$\begin{array}{l}\text { Where does existing development pose the greatest threat to aquatic communities, and where are the large, } \\
\text { relatively undeveloped areas? }\end{array}$ & Figures 3-5 and 3-6 \\
How do development levels vary by development types in aquatic communities? & Figure 3-7 \\
What is the size and distribution of fires since 1984 overall and by ecological community? & Figures 3-8 and 3-9; table 3-3 \\
$\begin{array}{l}\text { What is the distribution of potentially altered vegetation? } \\
\text { How do contemporary patterns of temperature and precipitation compare to that projected for relatively } \\
\text { hot-dry and warm-wet climate scenarios? }\end{array}$ & Figures 3-11 and 3-12 \\
\hline
\end{tabular}




\section{Management Questions and Results}

Where does existing development pose the greatest threat to terrestrial communities, and where are the large, relatively undeveloped areas (figs. 3-1 and 3-2)?

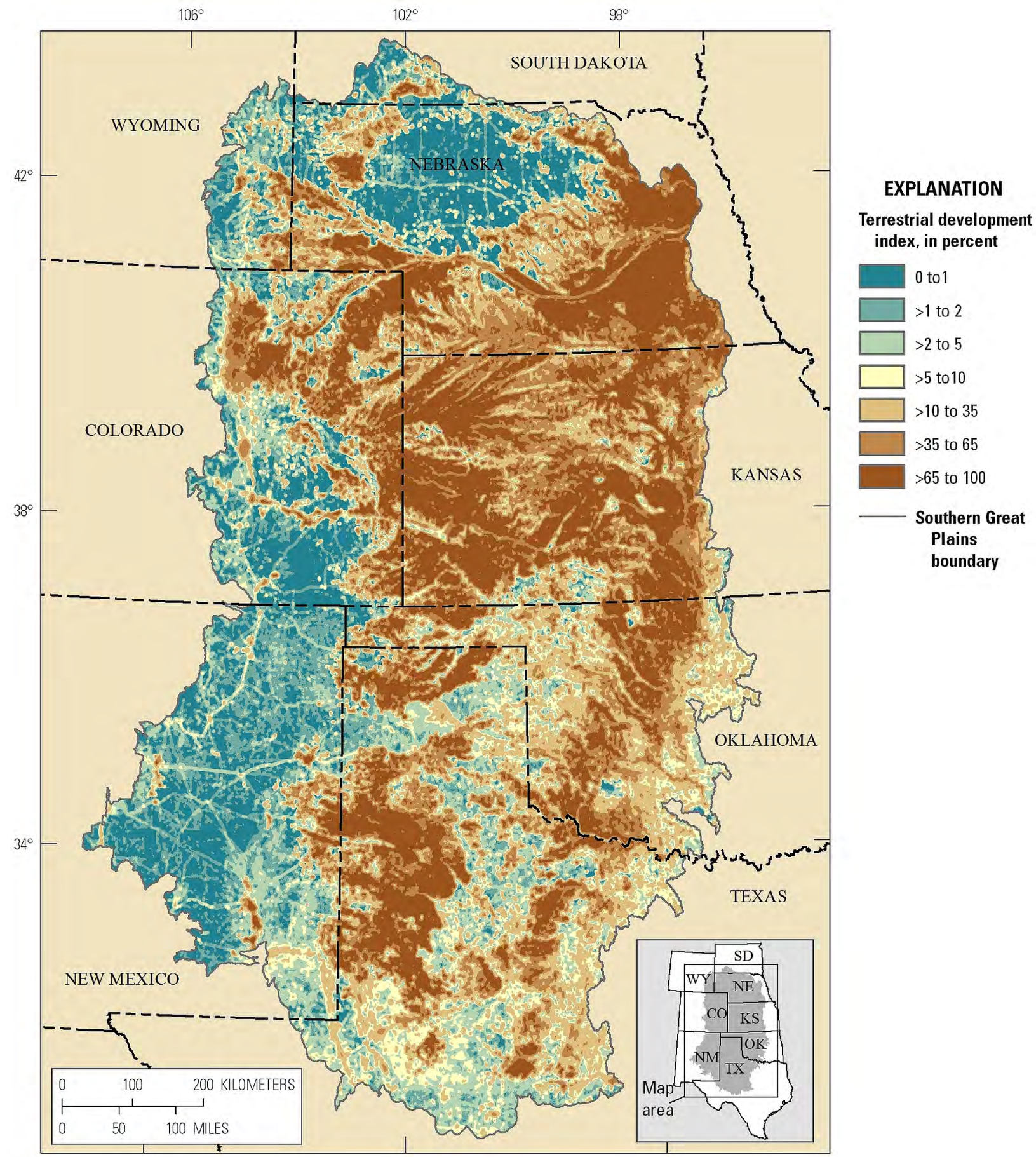

Figure 3-1. Terrestrial development index (TDI) in the Southern Great Plains. Relatively undeveloped areas were defined as having TDI scores $\leq 2$ percent. 


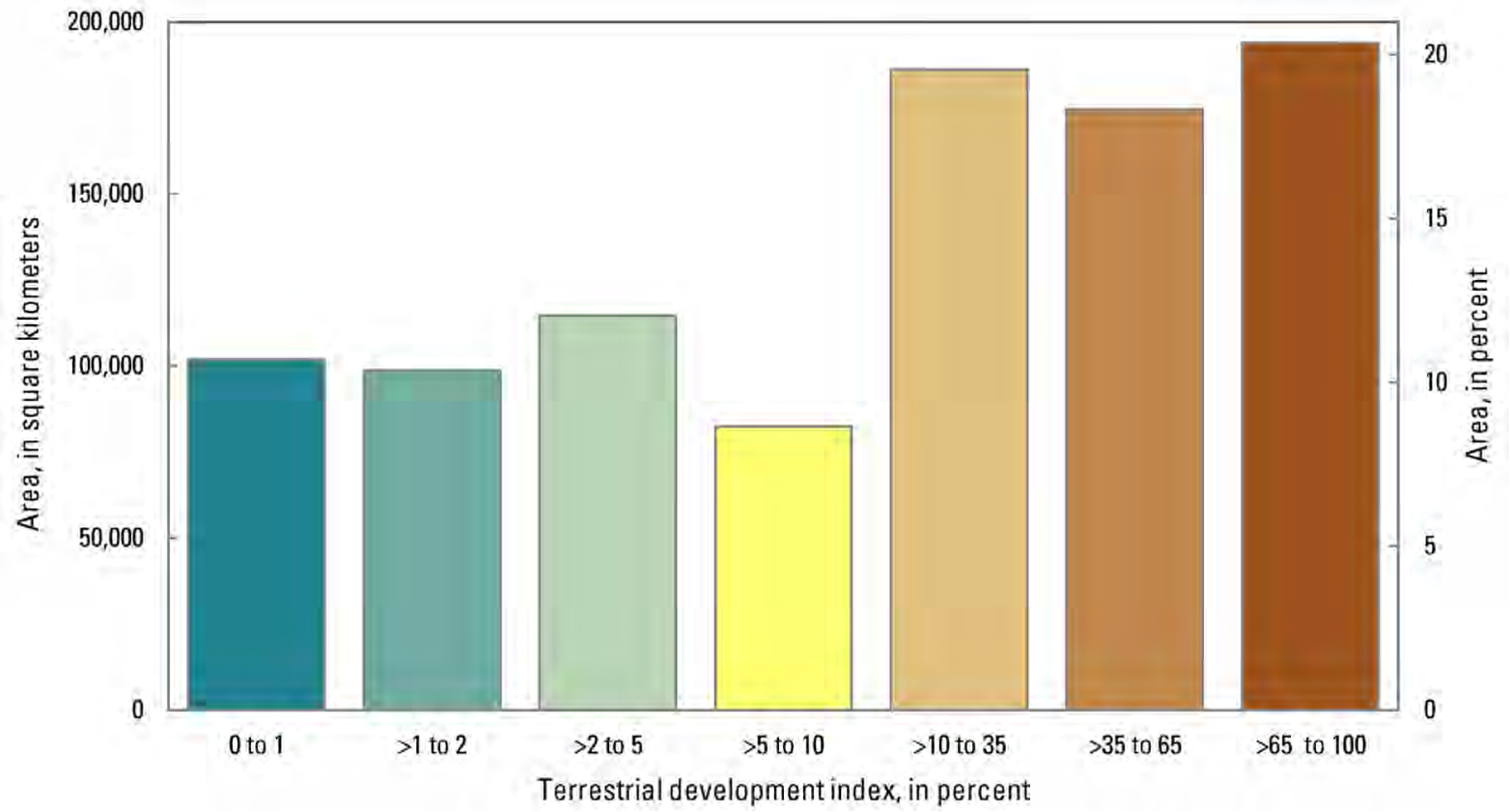

Figure 3-2. Total area in each terrestrial development index class in the Southern Great Plains. 


\section{2}

How do development levels vary by development types in terrestrial communities (figs. 3-3 and 3-4)?

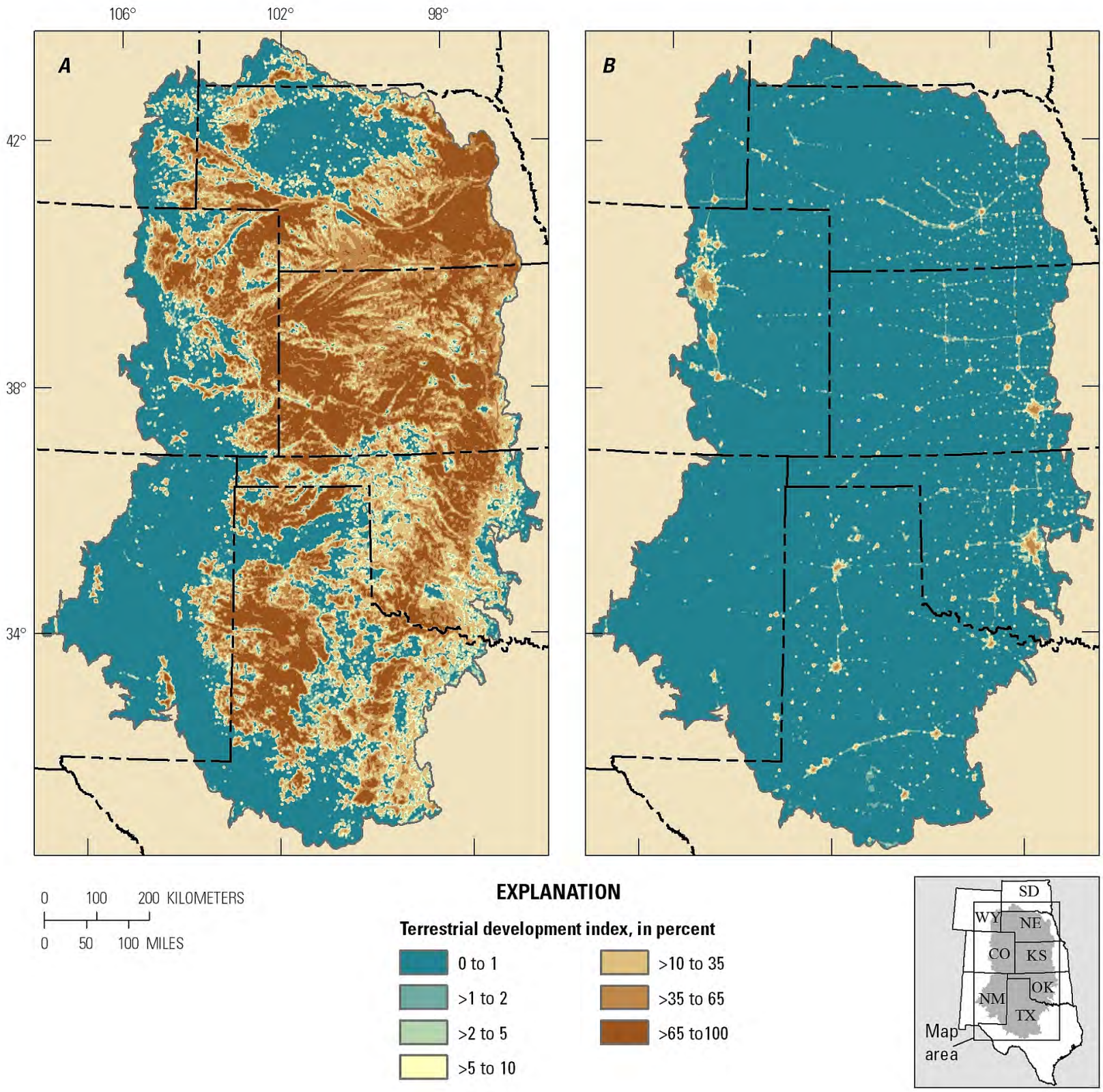

Figure 3-3. Terrestrial development index for $(A)$ agricultural croplands and $(B)$ urban areas in the Southern Great Plains. 

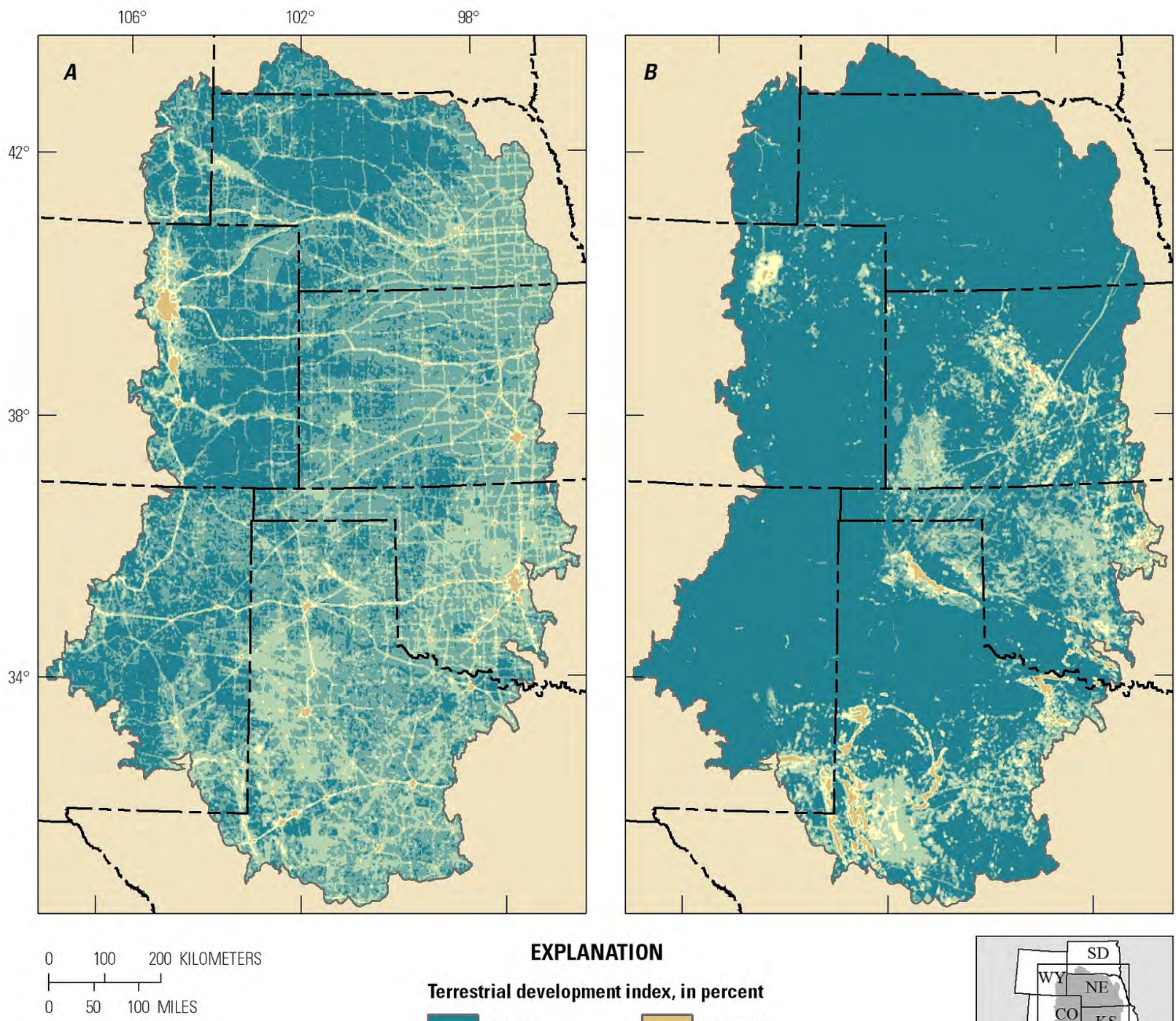

\section{EXPLANATION}

Terrestrial development index, in percent
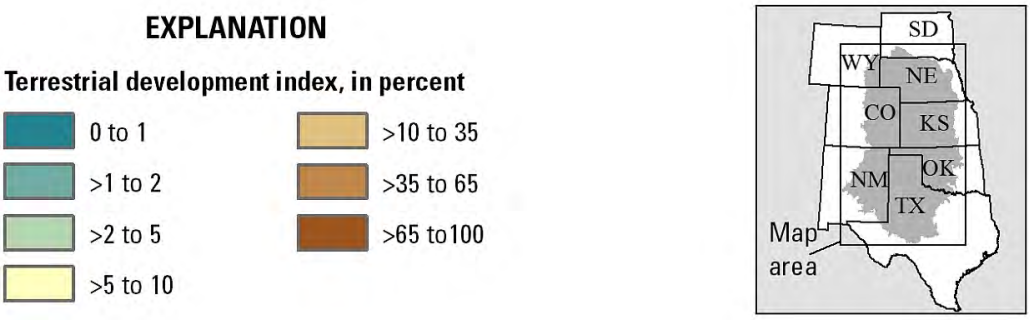

Figure 3-4. Terrestrial development index for $(A)$ transportation and $(B)$ energy and minerals development in the Southern Great Plains. 
Where does existing development pose the greatest threat to aquatic communities, and where are the large, relatively undeveloped areas (figs. 3-5 and 3-6)?

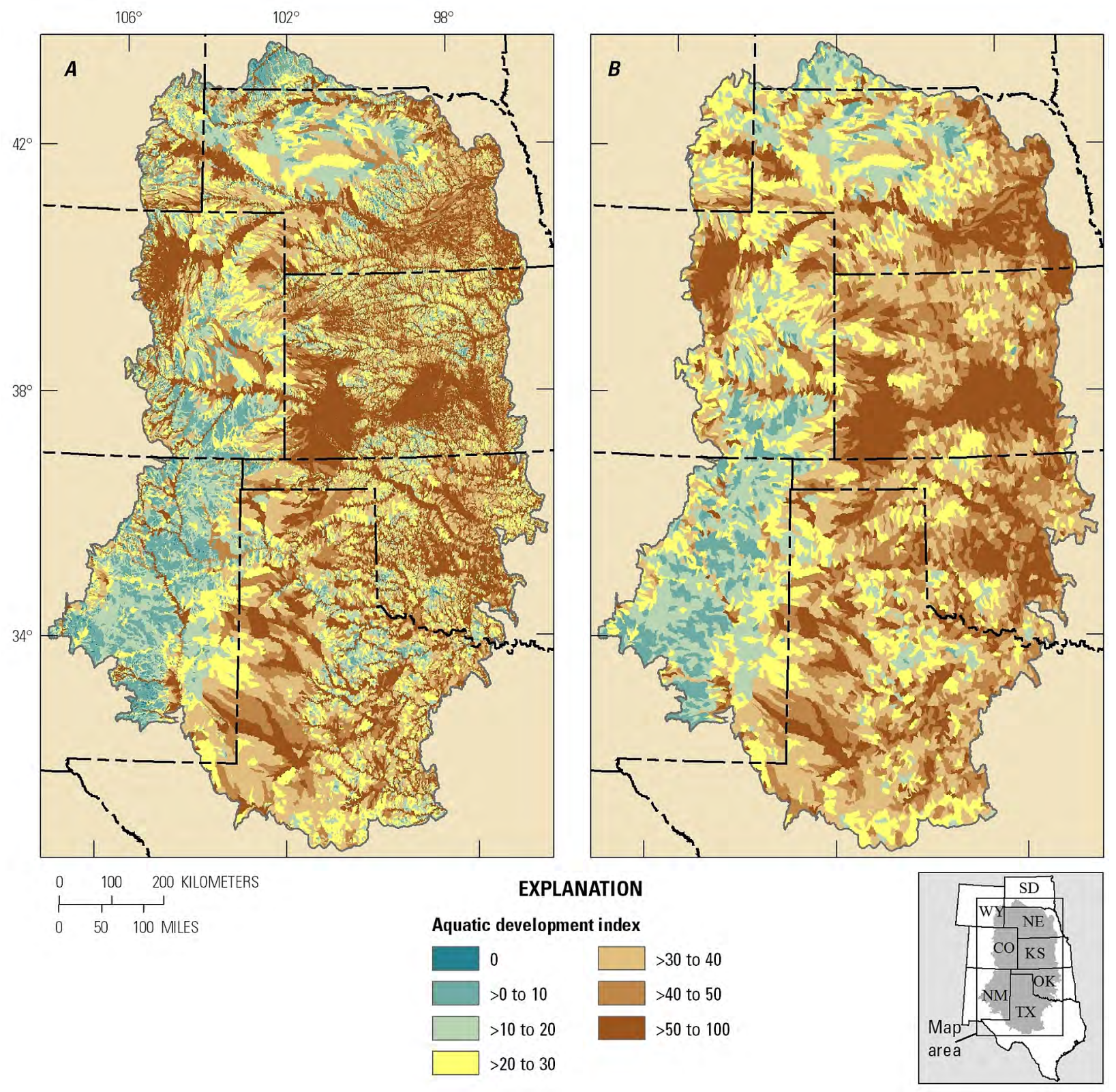

Figure 3-5. Aquatic development index (ADI) in the Southern Great Plains summarized by $(A)$ catchment (native resolution of index) and $(B)$ sixth-level watershed. Relatively undeveloped areas were defined as having ADI scores $\leq 20$. 


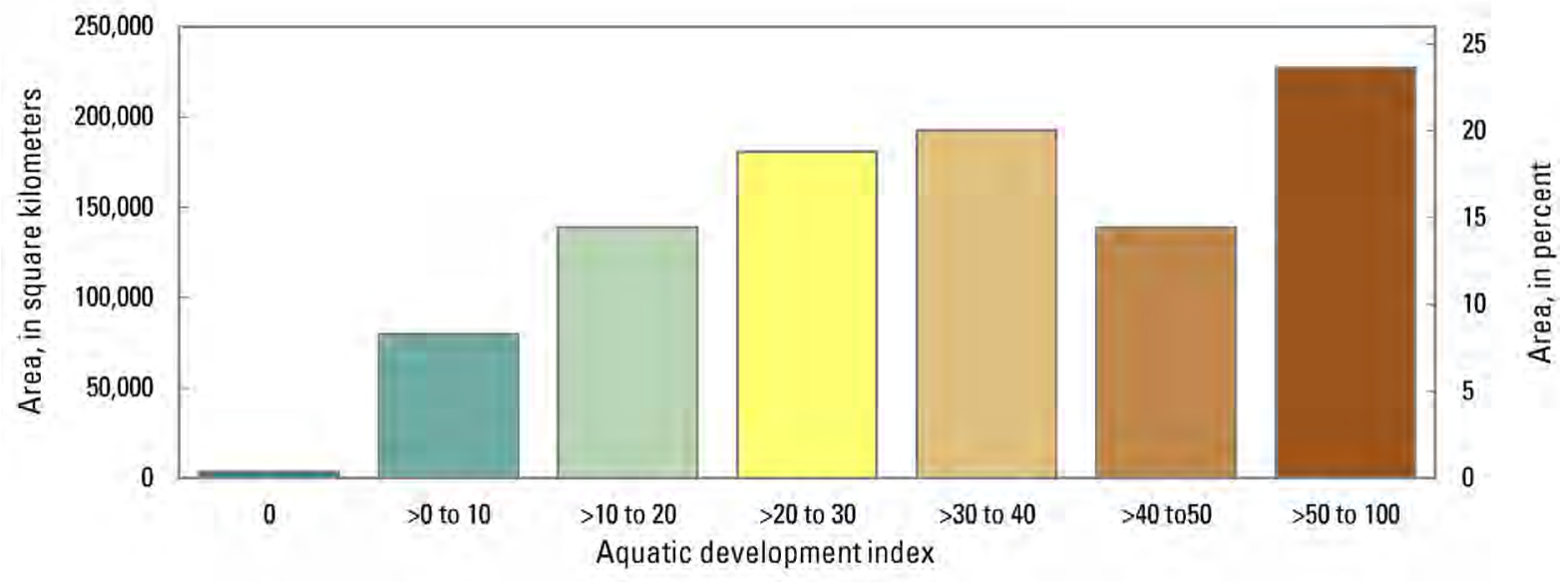

Figure 3-6. Total area in aquatic development index classes in the Southern Great Plains.

How do development levels vary by development types in aquatic communities (fig. 3-7)?

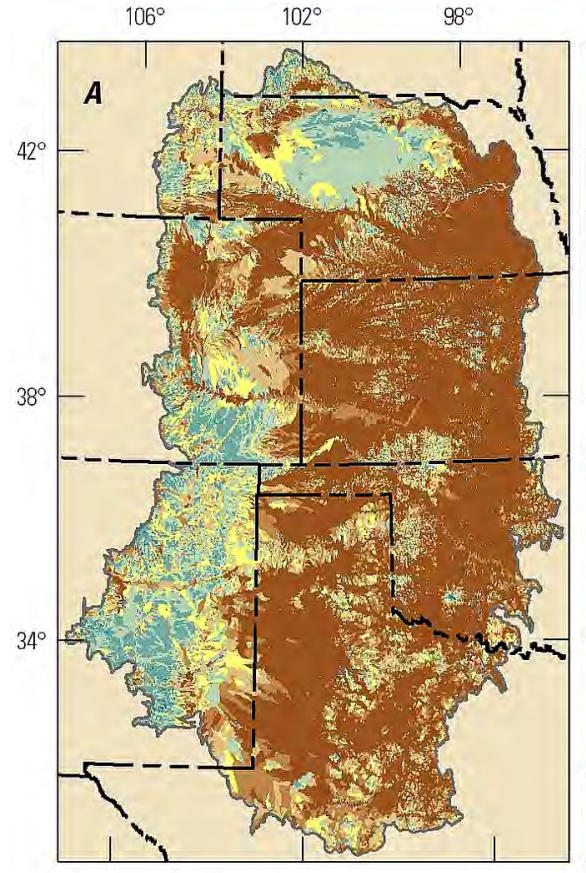

$0 \quad 100200$ KILOMETERS

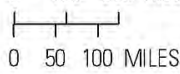

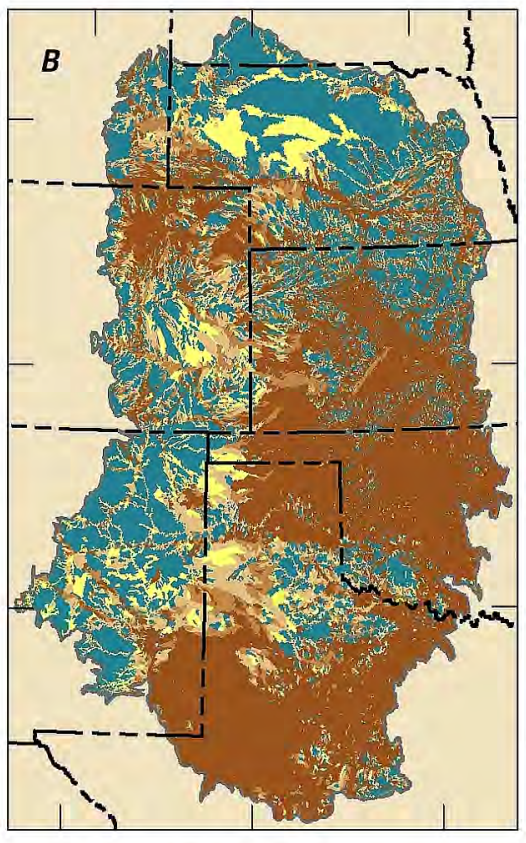

EXPLANATION

Aquatic development index

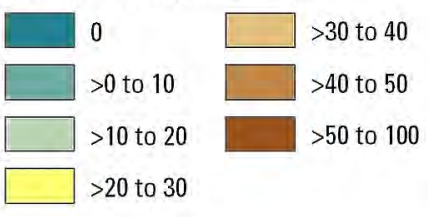

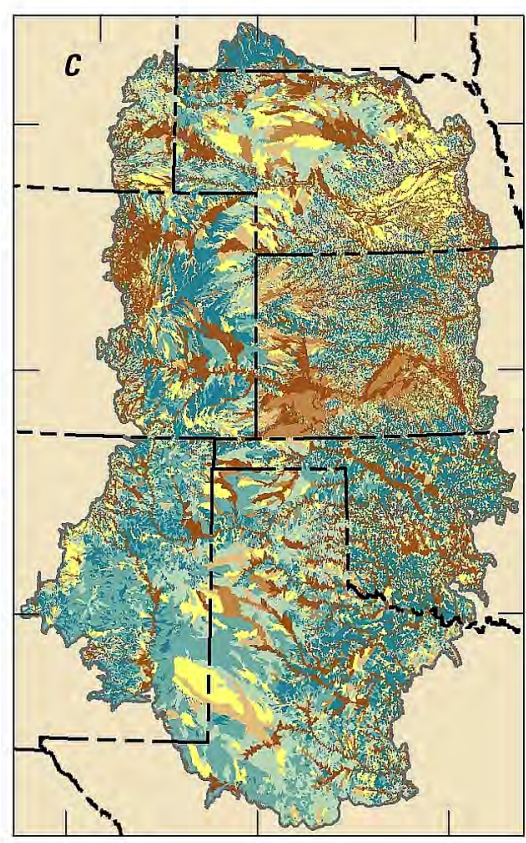

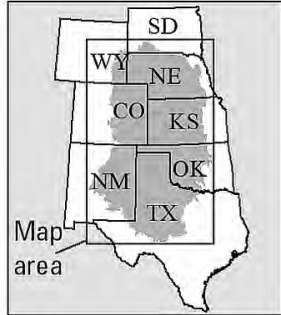

Figure 3-7. Aquatic development index for three classes of development in the Southern Great Plains, summarized by catchment. $A$, Agricultural cropland, urban, and transportation development. $B$, Energy and minerals development. $C$, Road and railroad stream crossings, dams, and diversions. 
What is the size and distribution of fires since 1984 overall and by ecological community (figs. 3-8 and 3-9; table 3-3)?

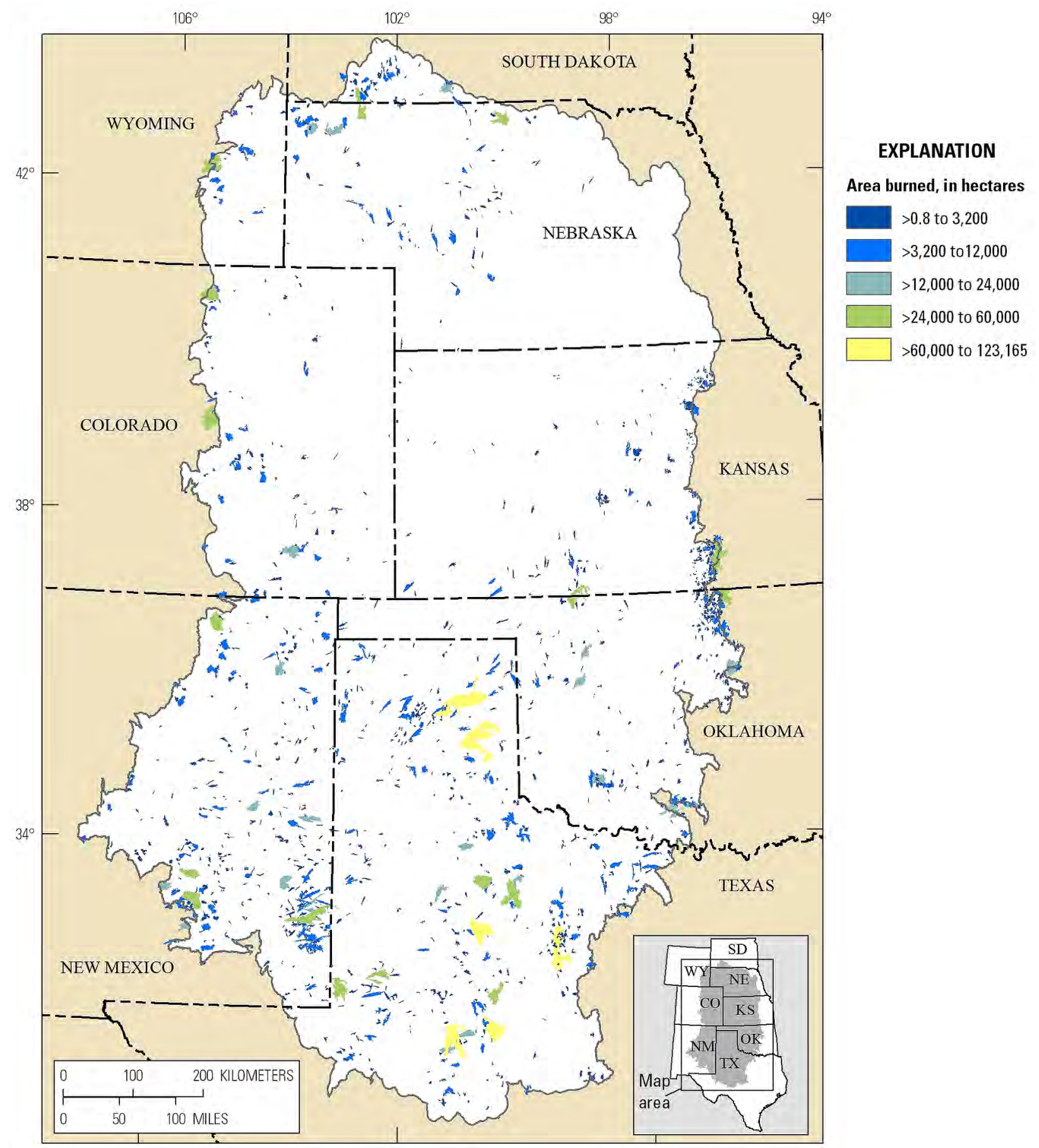

Figure 3-8. Fire perimeters in the Southern Great Plains, 1984-2014. Minimum mapping acreage for a fire is 405 hectares (1,000 acres), although some smaller fires may be mapped. 


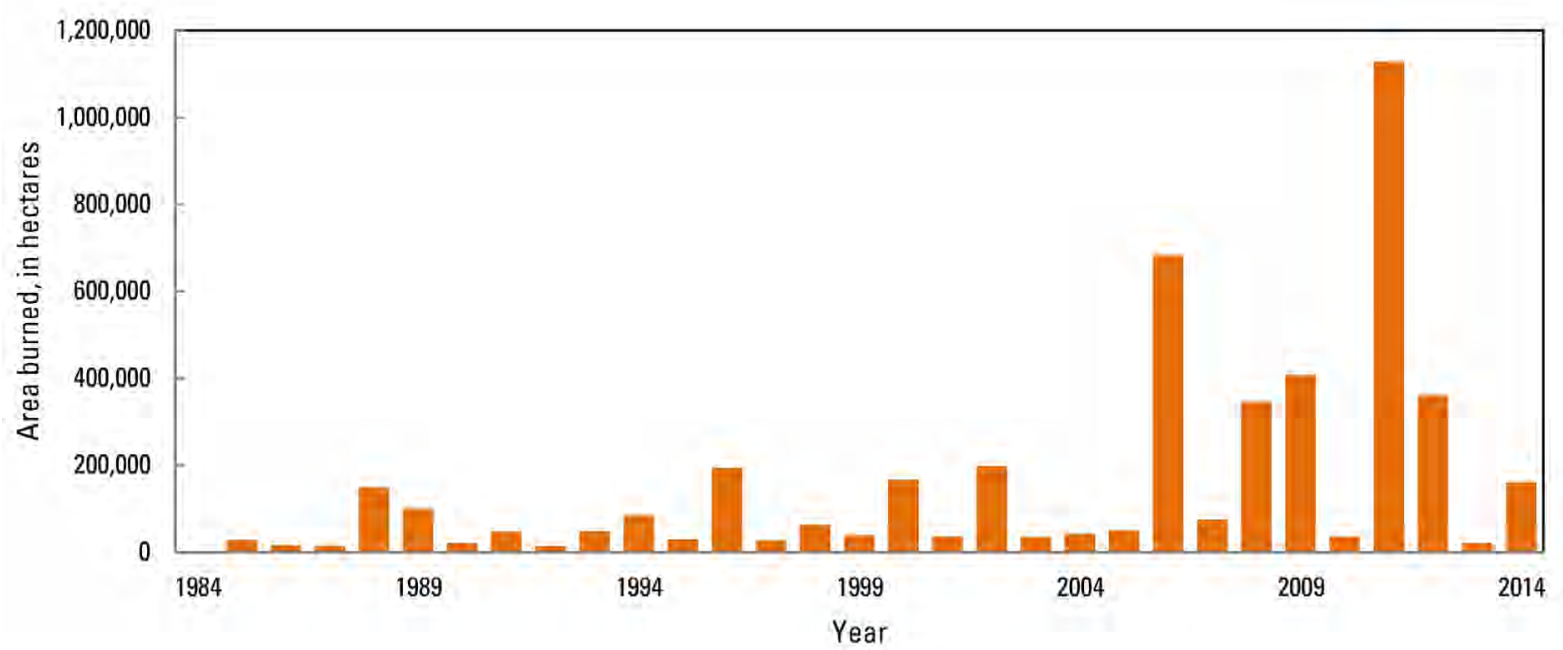

Figure 3-9. Area burned annually in the Southern Great Plains, 1984-2014.

Table 3-3. Area of ecological communities burned in the Southern Great Plains, 1984-2014.

[See appendix A for data source. ha, hectare]

\begin{tabular}{|c|c|c|c|c|}
\hline Ecological communities & $\begin{array}{l}\text { Area burned } \\
\text { by fire, } \\
\text { in ha' }\end{array}$ & $\begin{array}{l}\text { Percent of all } \\
\text { communities } \\
\text { burned by fire }\end{array}$ & $\begin{array}{c}\text { Community area, } \\
\text { in ha }\end{array}$ & $\begin{array}{c}\text { Percent of } \\
\text { community area } \\
\text { burned by fire }\end{array}$ \\
\hline Playa wetlands & 2,031 & 0.05 & 331,337 & 0.61 \\
\hline Mixed-grass prairie & 759,653 & 20.22 & $10,735,740$ & 7.08 \\
\hline Other grasslands ${ }^{2}$ & 826,922 & 22.01 & $9,183,646$ & 9.00 \\
\hline Shrubland, woodland, and forest & 581,147 & 15.47 & $10,211,464$ & 5.69 \\
\hline All communities ${ }^{3}$ & $3,756,462$ & 100.00 & $61,737,270$ & 6.08 \\
\hline
\end{tabular}

'Includes fires 405 ha (1,000 acres) or larger, although some smaller fires may be included. Excludes within-year repeat burns.

2"Other grasslands" includes foothill grassland, northwest mixed-grass prairie, saline grassland, semidesert grassland and shrubland, tallgrass prairie, and cool-season bunchgrass prairie.

${ }^{3}$ Fires in sparsely vegetated areas, low-intensity developed areas, and developed areas (totaling 374,800 ha) were not included. 
What is the distribution of potentially altered vegetation (fig. 3-10)?

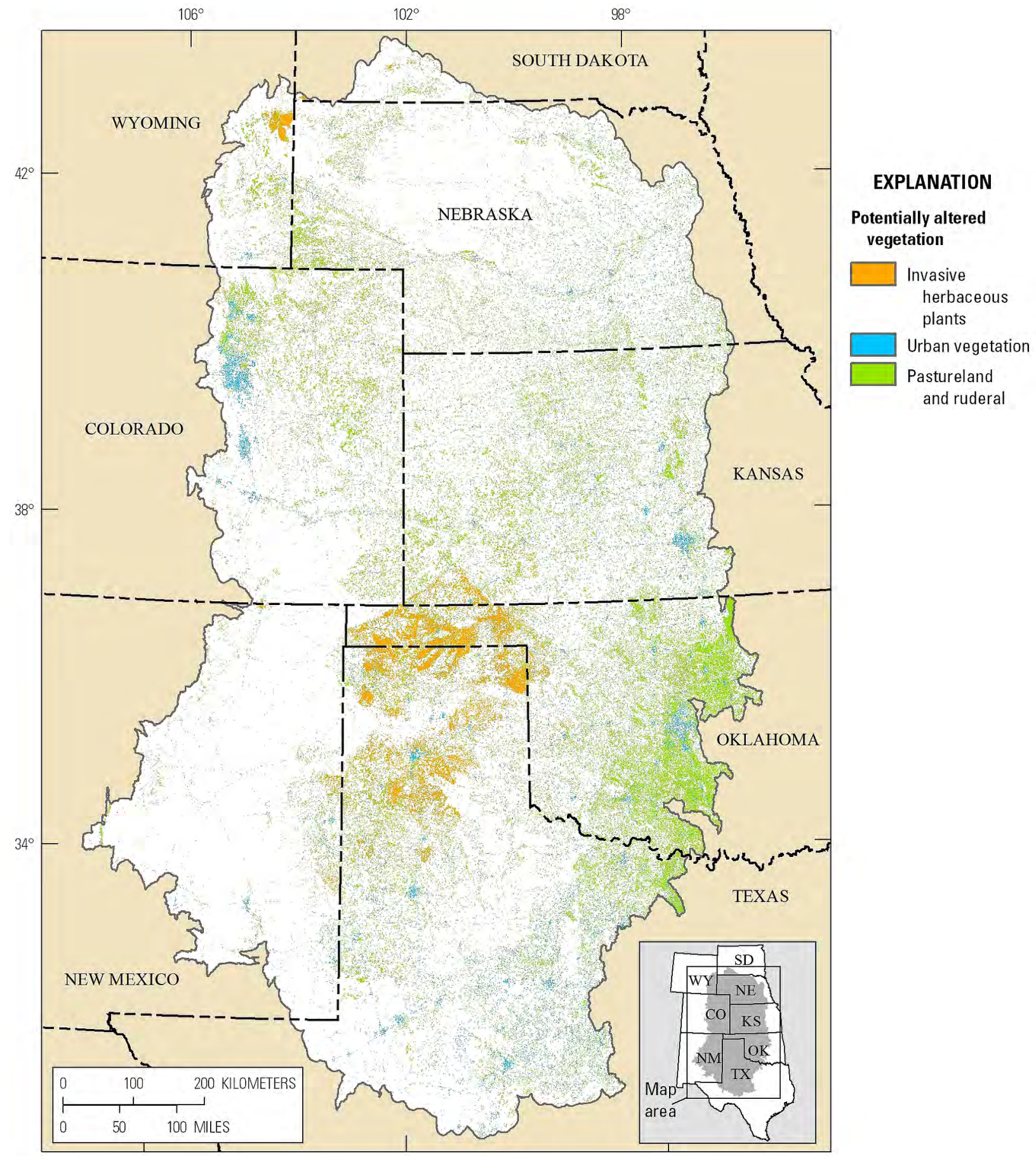

Figure 3-10. Potentially altered vegetation in the Southern Great Plains. 
How do contemporary patterns of temperature and precipitation compare to those projected for relatively hot-dry and warm-wet climate scenarios (figs. 3-11 and 3-12)?
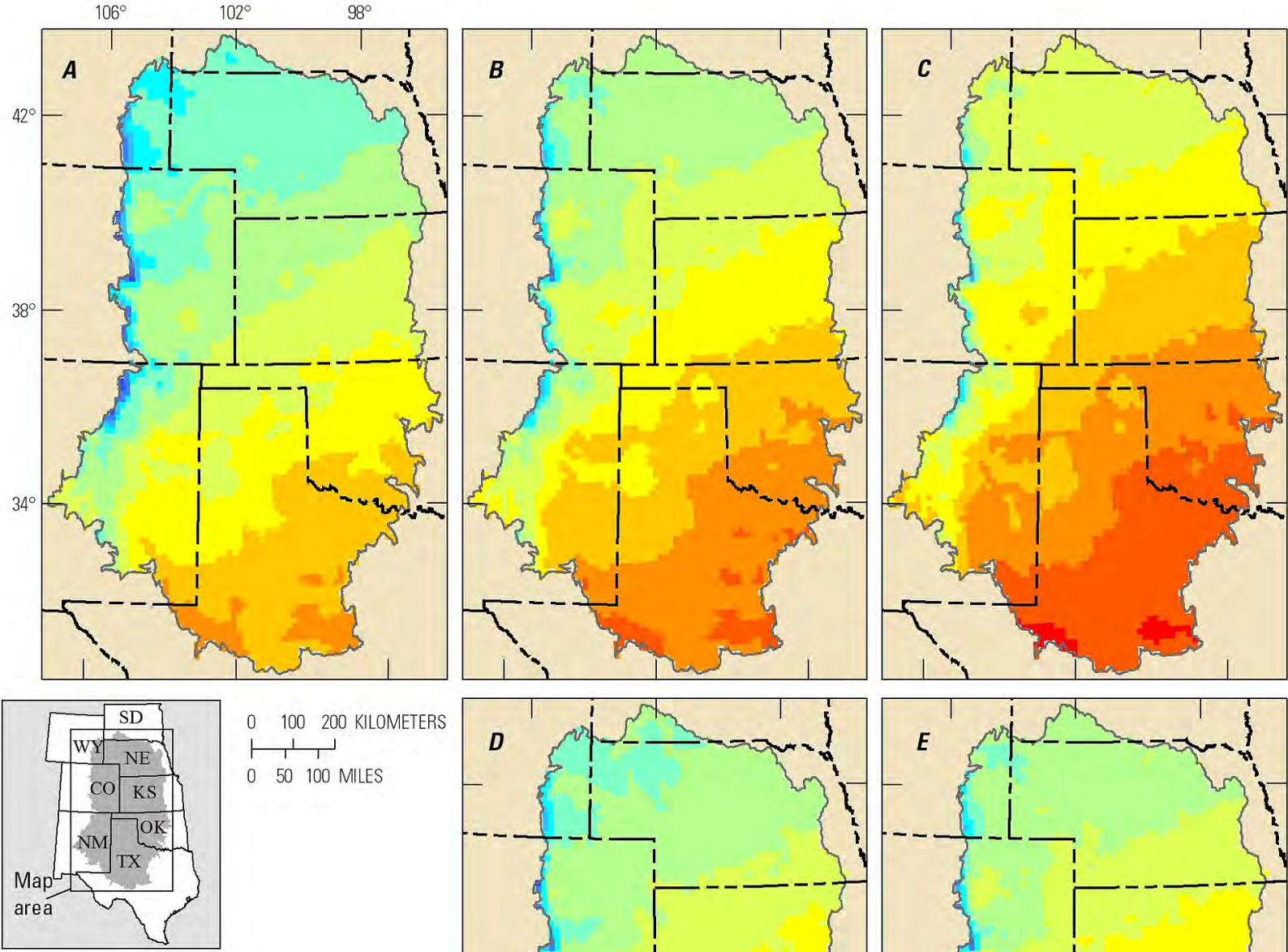

$0 \quad 100 \quad 200$ KILOMETERS
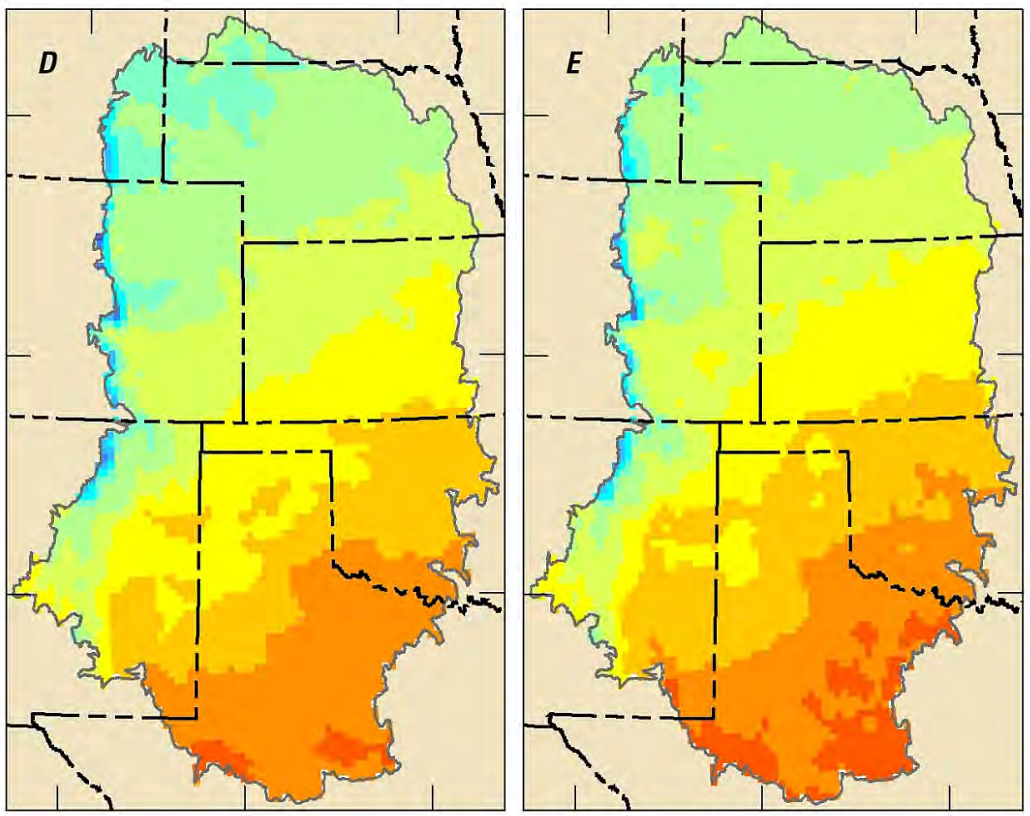

Figure 3-11. Average annual temperatures in the Southern Great Plains for $(A)$ 1981-2010, a hot and dry scenario for (B) 2016-2045 and (C) 2046-2075, and a warm and wet scenario for (D) 2016-2045 and (E) 2046-2075. 

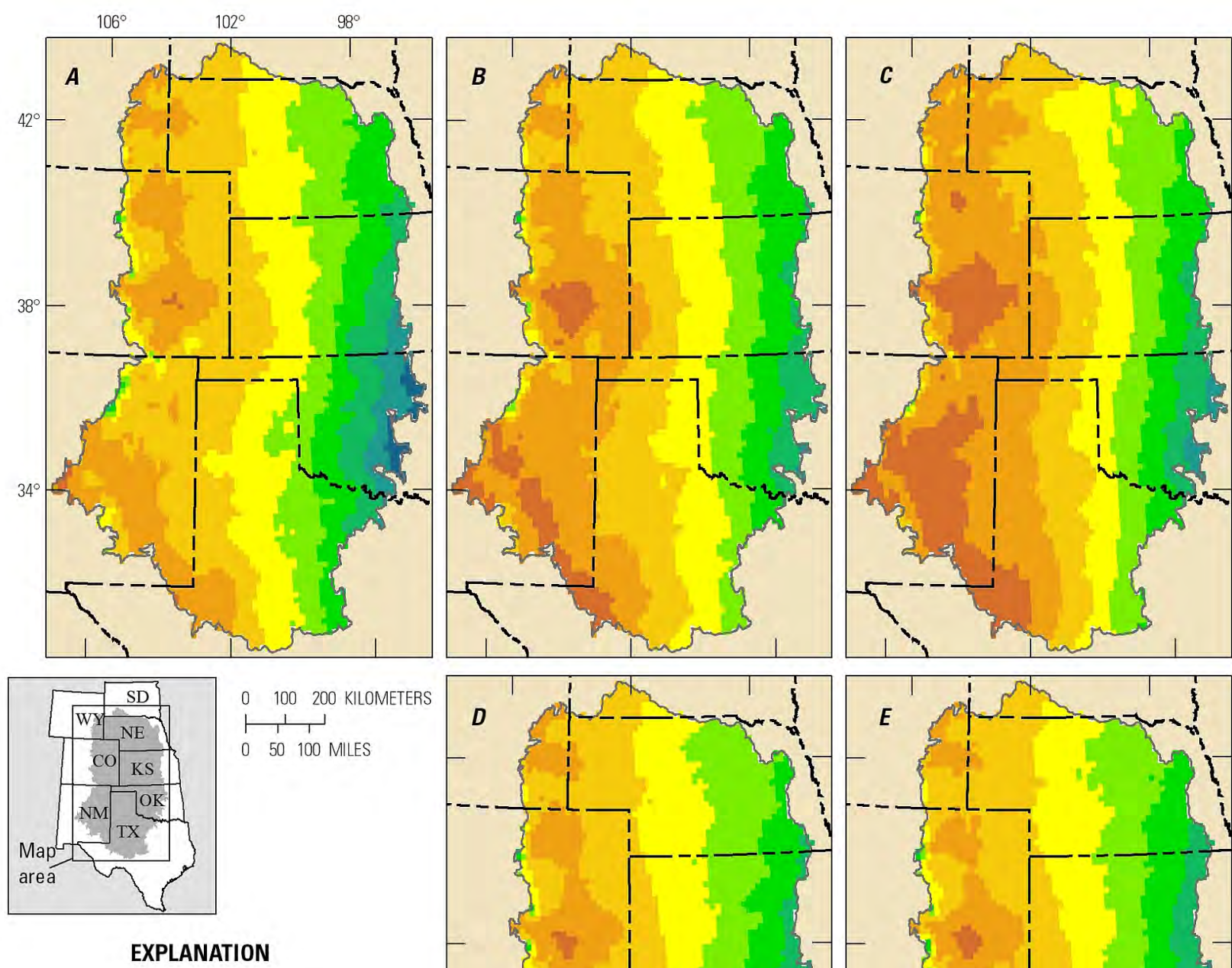

Average annual precipitation, in centimeters

\begin{tabular}{|c|c|}
\hline 10 to 20 & $>60$ to 70 \\
\hline$>20$ to 30 & $>70$ to 80 \\
\hline$>30$ to 40 & $>80$ to 90 \\
\hline$>40$ to 50 & $>90$ to 100 \\
\hline$>50$ to 60 & $>100$ to 110 \\
\hline
\end{tabular}
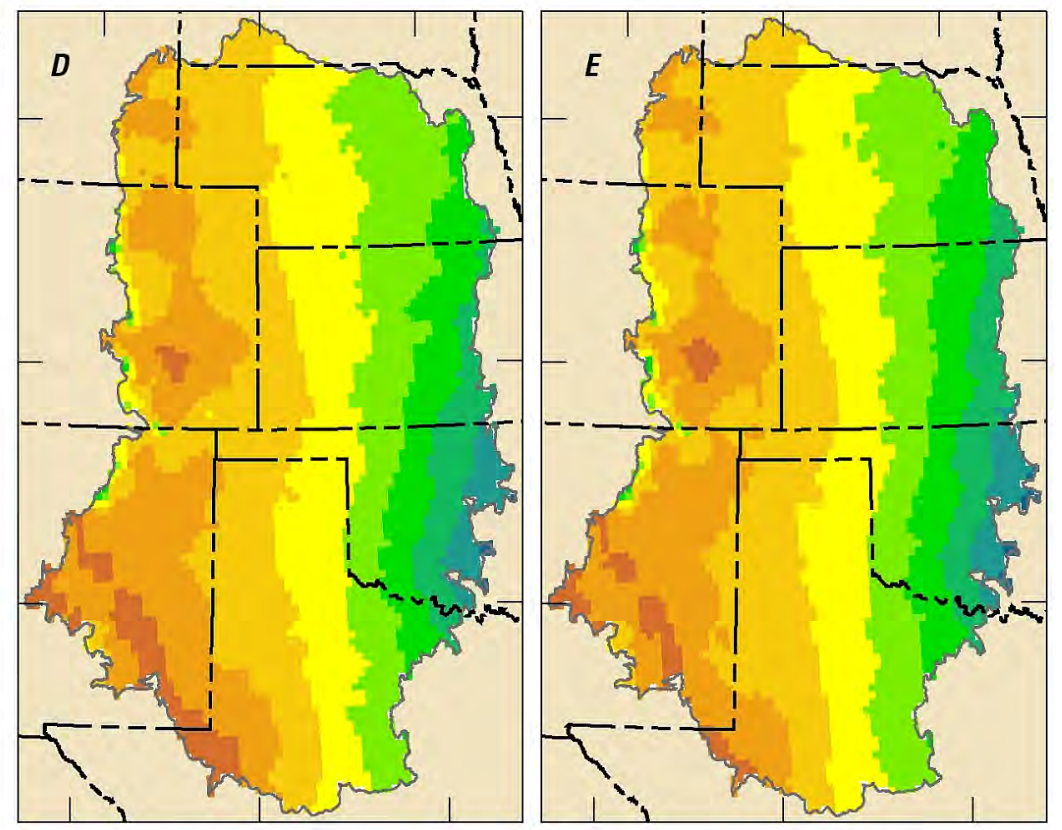

Figure 3-12. Average annual precipitation in the Southern Great Plains for $(A)$ 1981-2010, a hot and dry scenario for (B) 2016-2045 and (C) 2046-2075, and a warm and wet scenario for (D) 2016-2045 and (E) 2046-2075. 


\section{Summary}

- Terrestrial and aquatic development is greatest in the eastern half of the SGP. Agricultural croplands, energy development, road densities, dams, and diversions are more concentrated in the eastern portions of the SGP. Development is lower in the western portion where shortgrass prairie and intermittent streams are the dominant terrestrial and aquatic community types.

- Data on fire size and severity are limited, but the largest fires since 1984 occurred during severe widespread drought in 2006 and 2011. Of the area burned in 2006, greater than 68 percent occurred in either mixed-grass, shortgrass, or sand prairie (fig. 3-8). In 2011, nearly 60 percent of burned areas occurred across those three communities. Approximately 4 percent of the SPG burned over the past 30 years, which is quite limited compared to the amount of area that would have burned prior to EuroAmerican settlement. Historical fire regimes are poorly understood, but generally the fire return interval was less than 50 years, depending on the community type. Estimated fire return intervals were the shortest in the Nebraska Sand Hills and tallgrass prairie ( $0-10$ years) and mixed-grass prairie (11-15 years) and longer in shortgrass prairie (21-50 years) (LANDFIRE, 2012b).

- Data on invasive plant species are limited, but the best data and models for the SGP indicate the widespread potential for altered vegetation.

- There are two major climate gradients in the SGP: a west-east gradient of increasing precipitation and northwest-southwest gradient of increasing temperature. For both the hot-dry and warm-wet climate scenarios, temperatures were projected to increase throughout the SGP. Precipitation was projected to decrease in the southern portion of the region, particularly for the hot-dry scenario. This pattern contributes to the potential for changes in the distribution of SGP grasslands, as projected by other climate change models (Rehfeldt and others, 2012; chapter 4, "Grasslands").

\section{References Cited}

Assal, T.J., Melcher, C.P., and Carr, N.B., eds., 2015, Southern Great Plains Rapid Ecoregional AssessmentPre-assessment report: U.S. Geological Survey Open-File Report 2015-1003, 284 p., accessed September 2015 at https://doi.org/10.3133/ofr20151003.

Gutman, M.P., Parton, W.J., Cunfer, Geoff, and Burke, I.C., 2005, Population and environment in the U.S. Great Plains, in Entwisle, Barbara, and Stern, P.C., eds., Population, land use, and environment-Research directions: Washington, D.C., The National Academies Press, p. 84-105.

Hart, R.H., 2008, Land-use history on the shortgrass steppe, in Lauenroth, W.K., and Burke, I.C., eds., Ecology of the shortgrass steppe: Oxford, United Kingdom, Oxford University Press, p. 132-180.

LANDFIRE, 2012a, Existing Vegetation Type (ver. 1.3.0): U.S. Forest Service and U.S. Department of the Interior, accessed December 29, 2014, at https://landfire.gov/ NationalProductDescriptions21.php.

LANDFIRE, 2012b, Mean fire return interval (ver. 1.1.3): U.S. Geological Survey, Wildland Fire Science, Earth Resources Observation and Science Center, accessed March 4, 2015, at https://www.landfire.gov/ NationalProductDescriptions13.php.

National Park Service, 2008, Southern Plains Network vital signs monitoring plan: National Park Service, Natural Resource Technical Report NPS/SOPN/NRR-2008/028, $132 \mathrm{p}$.

Nativ, Ronit, and Smith, D.A., 1987, Hydrogeology and geochemistry of the Ogallala aquifer, southern High Plains: Journal of Hydrology, v. 91, p. 217-253.

Rehfeldt, G.E., Crookston, N.L., Sáenz-Romero, Cuauhtémoc, and Campbell, E.M., 2012, North American vegetation model for land-use planning in a changing climate-A solution to large classification problems: Ecological Applications, v. 22, no. 1, p. 119-141.

Samson, F.B., Knopf, F.L., and Ostlie, W.R., 2004, Great Plains ecosystems-Past, present, and future: Wildlife Society Bulletin, v. 32, no. 1, p. 6-15.

Wilson, S.G., 2009, Population dynamics of the Great Plains-1950 to 2007: U.S. Census Bureau report P25-1137, 19 p., accessed January 13, 2014, at http://www.census.gov/prod/2009pubs/p25-1137.pdf. 



\section{Chapter 4. Grasslands}

\section{Introduction}

Grasslands are the dominant vegetation of the Southern Great Plains (SGP), but they have been altered and fragmented by conversion to cropland, fire exclusion, loss of native herbivores, altered grazing regimes, energy development, and spread of invasive species (Conner and others, 2001). Consequently, the grasslands of the Great Plains are considered among the most threatened ecosystems in the world (Glaser, 2012). The SGP comprises a mosaic of grassland types characterized by distinct plant species assemblages and structures (Samson and Knopf, 1994; Shiflet, 1994). In general, the distribution and structure of SGP grasslands have been shaped primarily by relatively high average summer temperatures, persistent wind, and highly variable moisture regimes. These conditions often create annual summer drought that favors perennial warm-season grasses and forbs over woody vegetation (Samson and Knopf, 1994). An increasing gradient in precipitation from west to east contributes to a gradual transition from predominantly shortgrass prairie in the west, to mixed-grass prairie in the middle and east, to tallgrass prairie in the extreme east-central region of the SGP (see chapter 6, "Shortgrass Prairie," and chapter 5, "Mixed-Grass Prairie"). The transition zones are dynamic and can shift in response to climatic variation, especially prolonged drought (Weaver and others, 1996; Knight and others, 2014). Sand prairie, another major SGP grassland type, predominantly occurs in Nebraska and otherwise is widely scattered throughout much of the SGP (see chapter 7, "Sand Prairie").

Additional types of grassland communities with more restricted distributions in the SGP include northwest mixedgrass prairie and cool-season bunchgrass prairie in the

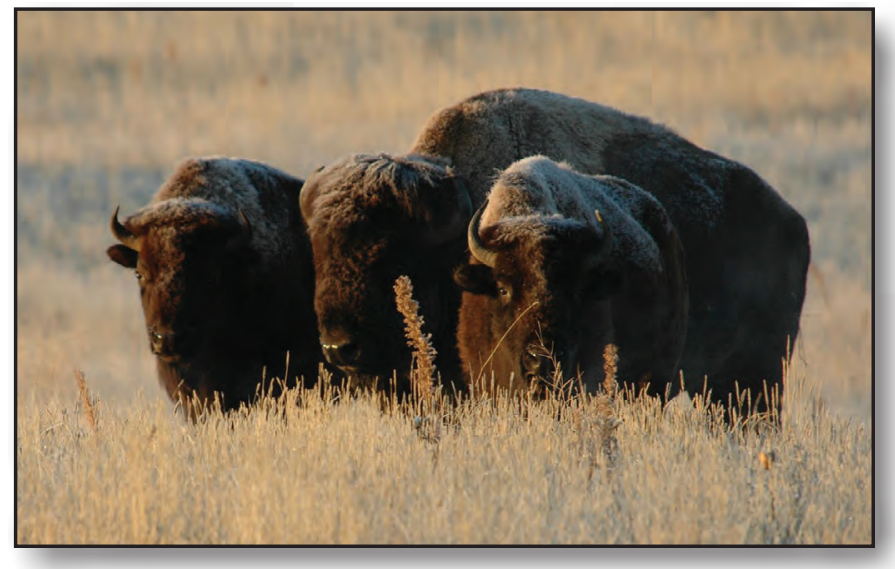

Rocky Mountain Arsenal, Colorado. Photograph by Rich Keen, DPRA (Creative Commons Attribution 2.0 Generic). northwest, foothill grassland in west-central areas, saline grassland in east-central Colorado, semidesert grassland and shrubland in the southwest, and midgrass prairie in the southeast. Although both mixed-grass and midgrass prairies are characterized by an average vertical structure of medium heights, mixed-grass prairie occurs in highly variable growing conditions that lead to a shifting mosaic of shorter to taller grasses; this may include sod- and bunch-forming grasses as well as warm- and cool-season grasses (Bragg and Steuter, 1996). In contrast, midgrass prairie is dominated primarily by mid-height warm season bunchgrasses, a function of the longer growing season and warmer average temperatures in the southeastern SGP. We included midgrass prairie in the mixed-grass prairie community.

Historically, fire, herbivory, other animal activities (trampling, wallowing, and burrowing), and drought were the primary agents of natural disturbances in SGP grasslands. Tornados, deep snow drifts, deep freezes, floods, and other weather events also influenced grassland dynamics (Mutel and Emerick, 1984). Change agents strongly affecting the composition and structure of SGP grasslands since EuroAmerican settlement include agricultural conversion, livestock grazing, loss of native herbivores, and altered fire regimes (Chaney and others, 1990; Weaver and others, 1996; Derner and others, 2009). For example, different grazing patterns between migratory bison and domestic livestock have shifted the grazing regime from intermittent and intensive to more continuous and consistent grazing (Weaver and others, 1996). More recently, energy and urban development and invasive plant species are also altering SGP grasslands (Engle and others, 1996; Glaser, 2012). Additional background information can be found in the SGP pre-assessment report (Assal and others, 2015).

\section{Rapid Ecoregional Assessment Components Evaluated for Grasslands}

The key ecological attributes and change agents addressed by core management questions for grasslands include amount and distribution, landscape structure (patch size), development, invasive woody species, and climate change (tables 4-1 and $4-2$ ). Fire occurrence and potentially altered vegetation (including invasive herbaceous plants) were evaluated for the entire SGP (see chapter 3, "Change Agents"). Overall landscape-level ranking variables are summarized in table $4-3$. The core and integrated management questions are listed in table 4-4. 
Table 4-1. Key ecological attributes and associated indicators used to address core management questions for grasslands for the Southern Great Plains Rapid Ecoregional Assessment.

\begin{tabular}{lll}
\hline \multicolumn{1}{c}{ Attributes } & \multicolumn{1}{c}{ Variables } & \multicolumn{1}{c}{ Indicators $^{1}$} \\
\hline Amount and distribution & Total area & Estimated historical and baseline distributions ${ }^{2}$ of all grassland types \\
Landscape structure & Patch size & Patch sizes for estimated historical and baseline distributions of all grassland types \\
Landscape dynamics & Fire occurrence & See chapter 3, "Change Agents" \\
\hline
\end{tabular}

${ }^{1}$ See chapter 2, "Methods Overview," and appendix A for methods and datasets used.

${ }^{2}$ Baseline distribution is determined by the most current regional data available.

Table 4-2. Anthropogenic change agents and associated indicators used to address core management questions for grasslands for the Southern Great Plains Rapid Ecoregional Assessment.

[km, kilometer; mi, mile]

\begin{tabular}{|c|c|c|}
\hline \multirow{2}{*}{$\begin{array}{r}\text { Attributes } \\
\text { Development }\end{array}$} & Variables & Indicators' \\
\hline & Index of fragmentation & Patch sizes for relatively undeveloped ${ }^{2}$ grasslands \\
\hline Climate change & $\begin{array}{l}\text { Potential grassland change as a function } \\
\text { of projected temperature and precipitation }\end{array}$ & $\begin{array}{l}\text { Potential distribution of bioclimatic envelope conducive to grasslands in } 2030 \\
\text { and } 2060^{3}\end{array}$ \\
\hline
\end{tabular}

${ }^{1}$ See chapter 2, "Methods Overview," and appendix A for methods and datasets used.

${ }^{2}$ Terrestrial development index score less than or equal to 2 percent.

${ }^{3}$ Bioclimatic envelope represents the climatic conditions conducive for grasslands as modeled by Rehfeldt and others (2012).

Table 4-3. Landscape-level variables used to address the integrated management question for grasslands. Ranks for landscape-level area and development were combined into an overall landscape-level rank for the Southern Great Plains Rapid Ecoregional Assessment.

[>, greater than; km, kilometer; mi, mile]

\begin{tabular}{|c|c|c|c|c|}
\hline \multirow{2}{*}{$\begin{array}{l}\text { Landscape-level } \\
\text { variables }^{1}\end{array}$} & \multirow{2}{*}{ Description } & \multicolumn{3}{|c|}{ Relative rank ${ }^{2}$} \\
\hline & & Lowest & Medium & Highest \\
\hline Area & $\begin{array}{l}\text { Percentage of 5-km-radius (3.11-mi) moving window classified as } \\
\text { baseline grasslands }\end{array}$ & $>0-57.2$ & $>57.2-79.8$ & $>79.8$ \\
\hline Development & $\begin{array}{l}\text { Mean terrestrial development index score for baseline grasslands within } \\
\text { a 5-km-radius (3.11-mi) moving window }\end{array}$ & $0-2$ & $>2-10$ & $>10$ \\
\hline
\end{tabular}

'See chapter 2, "Methods Overview," and appendix A for methods and datasets used.

${ }^{2}$ Ranking breakpoints for area of grasslands were determined from equal subsets of the data. Ranking breakpoints for terrestrial development index scores were standardized for all terrestrial conservation elements.

Table 4-4. Management questions addressed for grasslands for the Southern Great Plains Rapid Ecoregional Assessment.

\begin{tabular}{|c|c|}
\hline $\begin{array}{r}\text { Core management questions }^{1} \\
\end{array}$ & Results \\
\hline What are the estimated historical and baseline distributions of grasslands? & Figures $4-1$ and $4-2$ \\
\hline Where does existing development pose the greatest threat to grasslands, and where are the large, relatively undeveloped areas? & Figures $4-3$ and $4-4$ \\
\hline Where are grasslands potentially vulnerable to honey mesquite and eastern redcedar expansion? & Figure 4-7 \\
\hline Where are grasslands potentially vulnerable to projected climate change? & Figure 4-8 \\
\hline Integrated management question ${ }^{2}$ & Results \\
\hline
\end{tabular}

'See chapter 11, "Data Gaps, Limitations, and Uncertainty," for management questions that could not be addressed.

${ }^{2}$ See table $4-3$. 


\section{Management Questions and Results}

What are the estimated historical and baseline distributions of grasslands (figs. 4-1 and 4-2)?

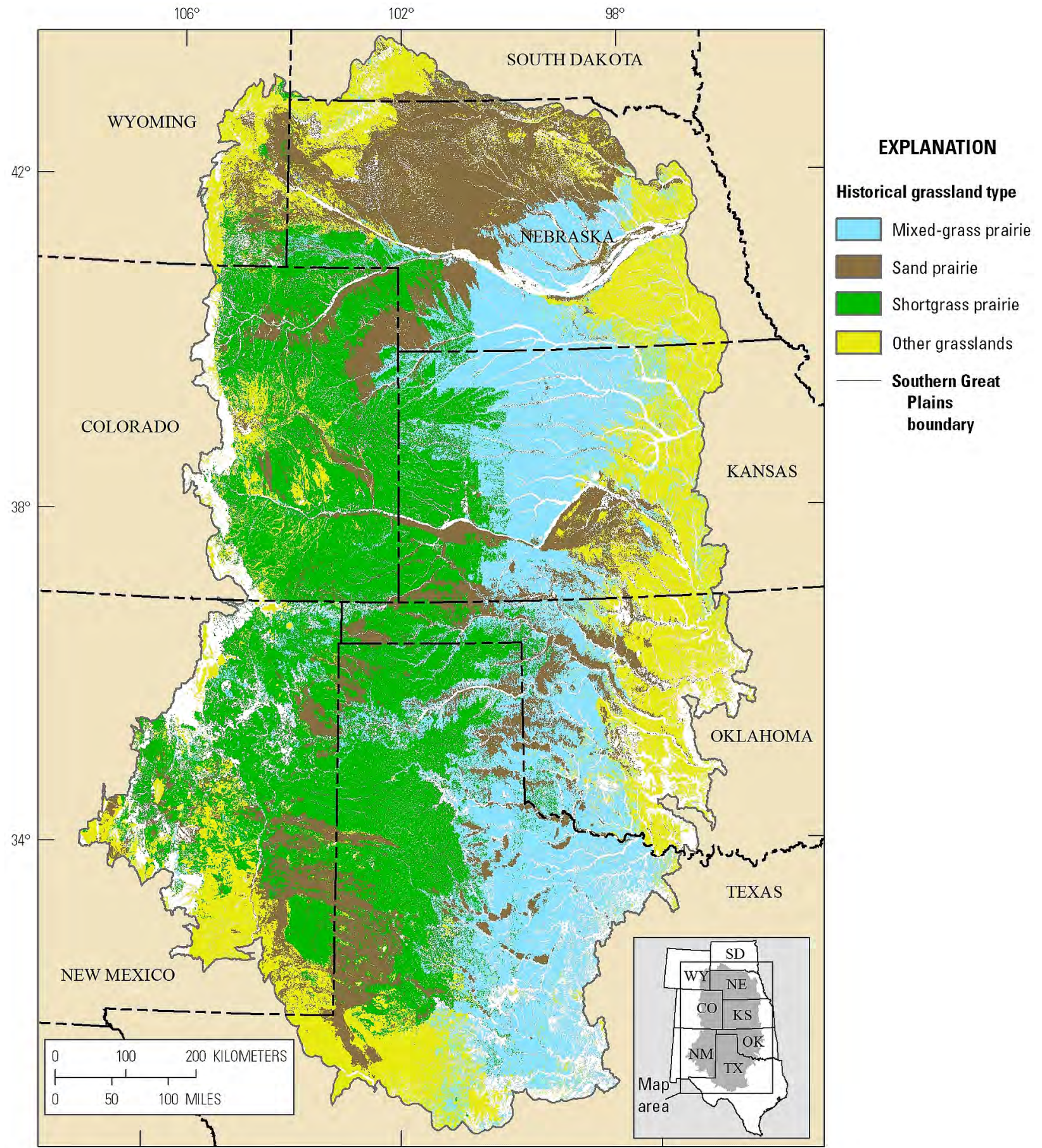

Figure 4-1. Estimated historical distribution of grasslands in the Southern Great Plains. The "other grasslands" community includes tallgrass, northwest mixed-grass, and cool-season bunchgrass prairies; foothill and saline grasslands; and semidesert grassland and shrubland. 


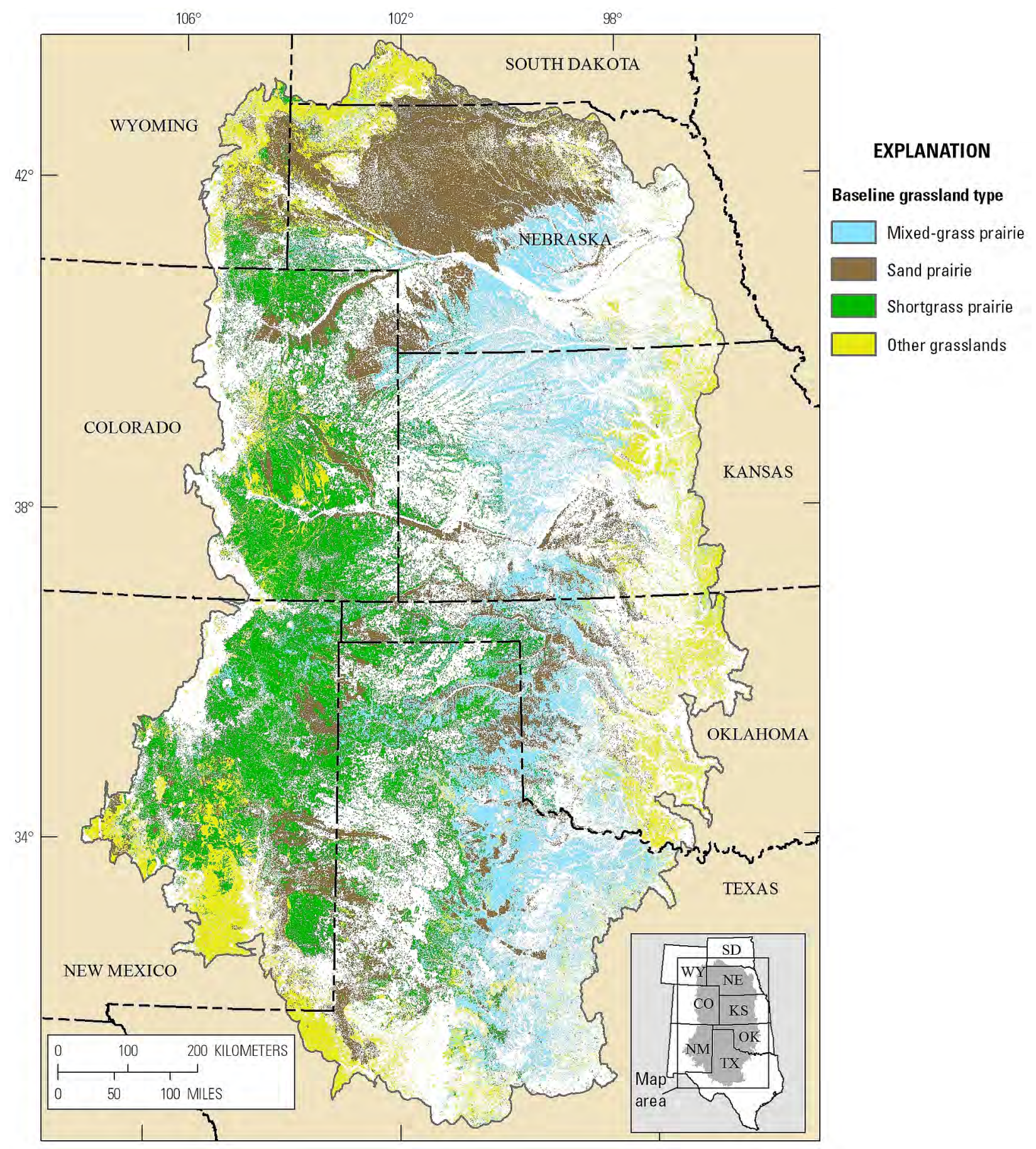

Figure 4-2. Baseline distribution of grasslands in the Southern Great Plains. The "other grasslands" community includes tallgrass, northwest mixed-grass, and cool-season bunchgrass prairies; foothill and saline grasslands; and semidesert grassland and shrubland. 
Where does existing development pose the greatest threat to grasslands, and where are the large, relatively undeveloped areas (figs. 4-3 and 4-4)?

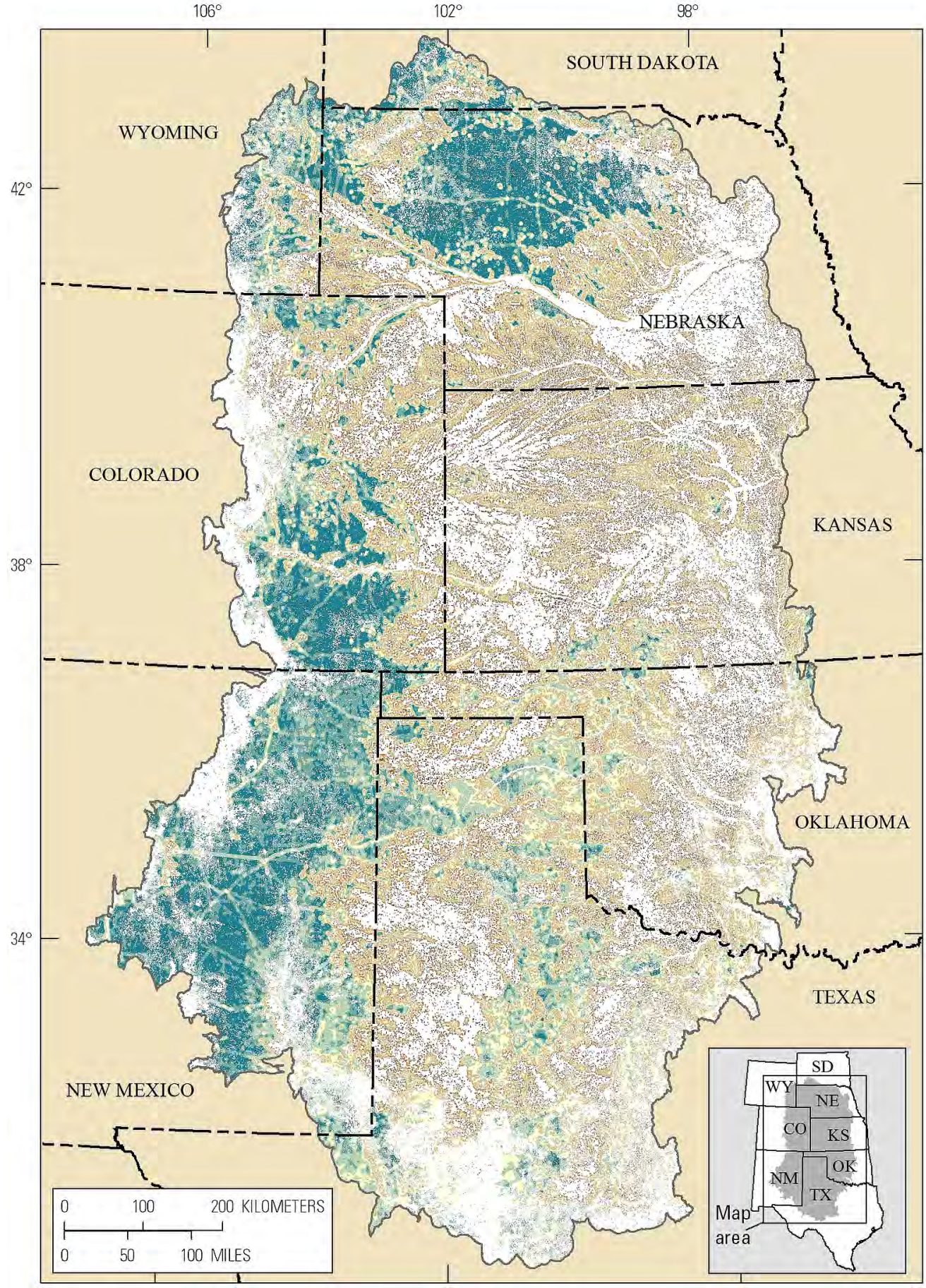

\section{EXPLANATION}

Terrestrial development index, in percent

0 to 1
$\square>1$ to 2
$\square>2$ to 5
$\square>5$ to 10
$\square>10$ to 35
$\square>35$ to 65
$\square 65$ to 100

Figure 4-3. Terrestrial development index for baseline grasslands in the Southern Great Plains. 


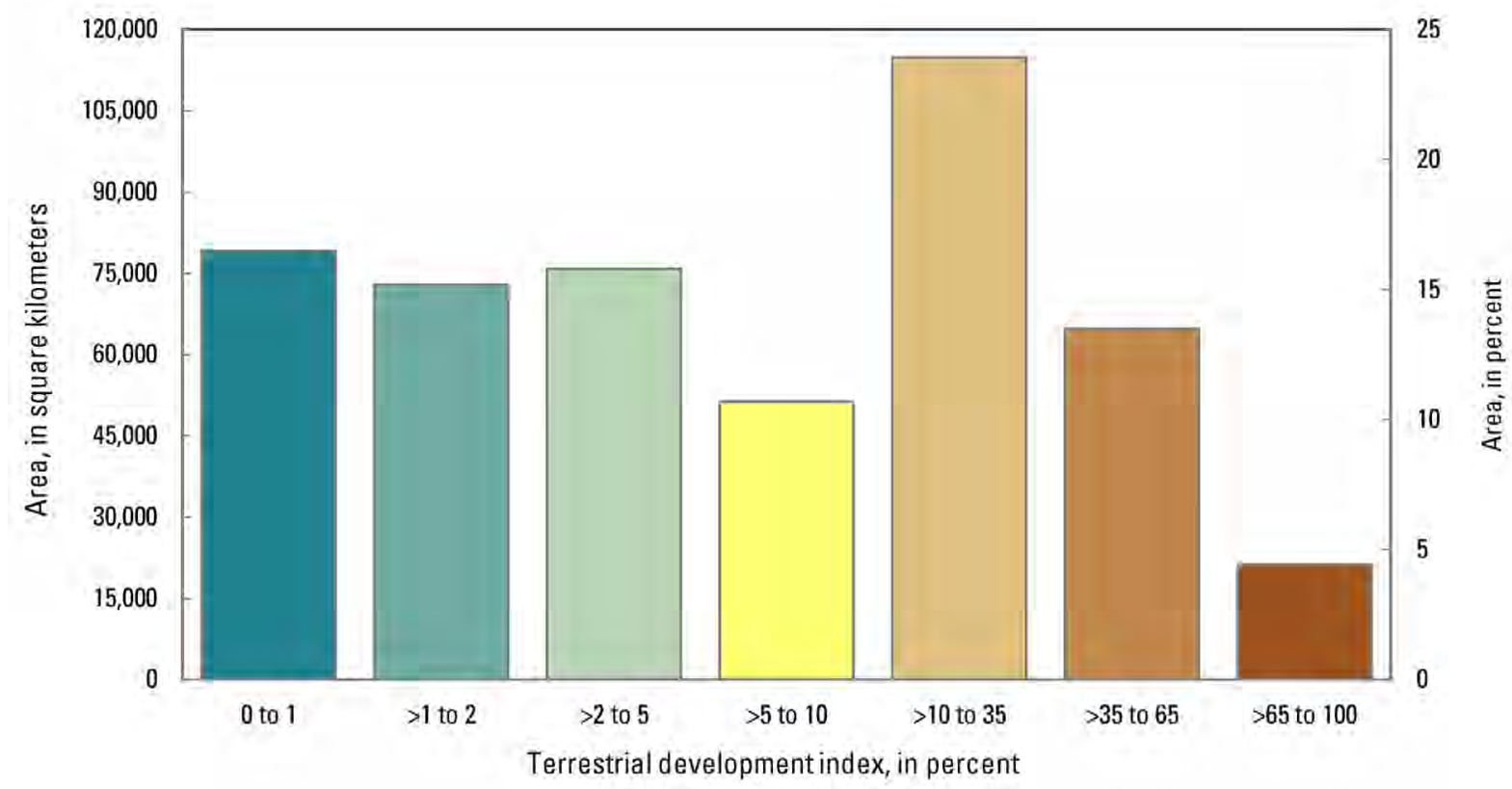

Figure 4-4. Area of baseline grasslands by terrestrial development index class in the Southern Great Plains.

How has development fragmented grasslands (figs. 4-5 and 4-6)?

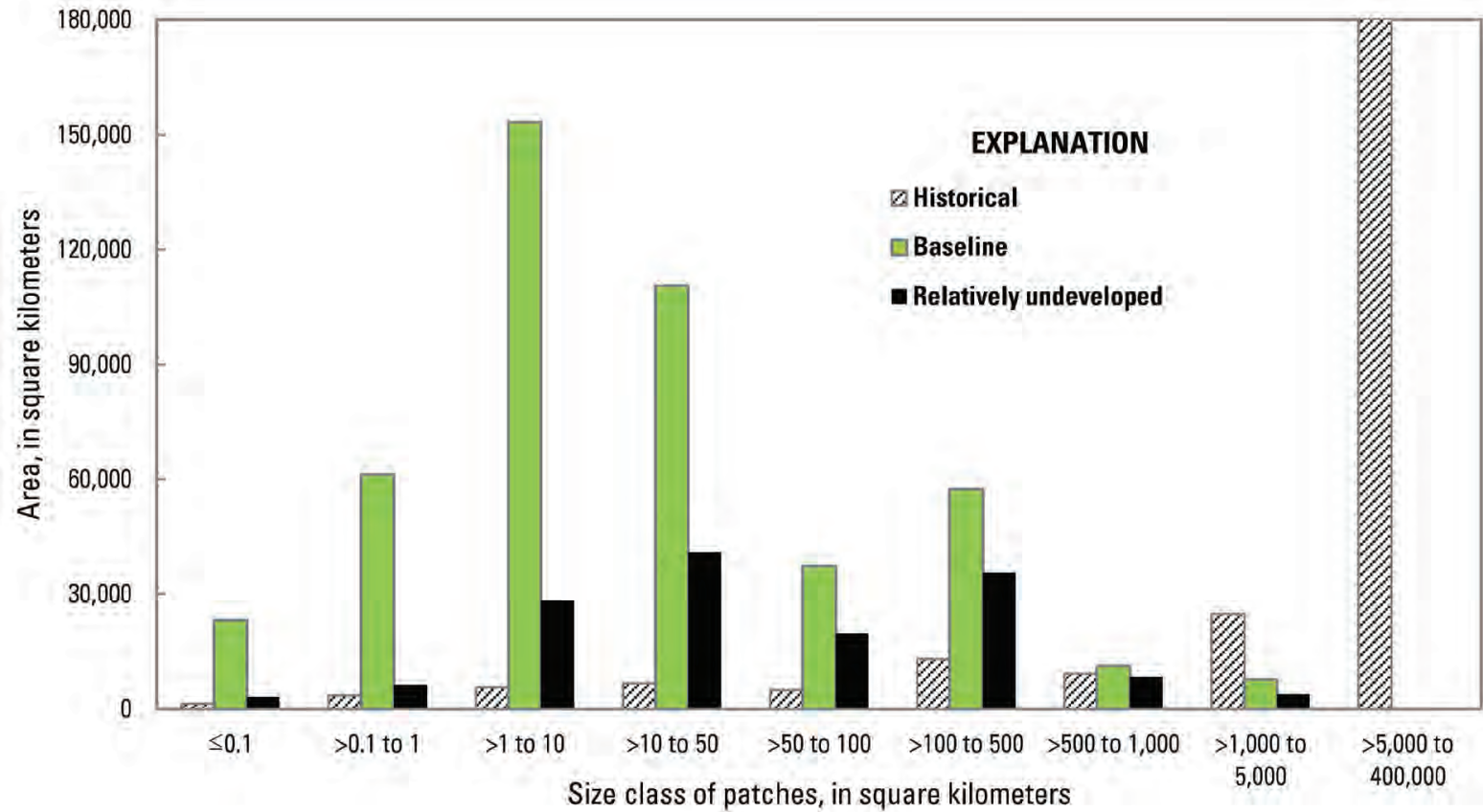

Figure 4-5. Area of grasslands in the Southern Great Plains as a function of patch size for historical, baseline, and relatively undeveloped conditions (terrestrial development index score $\leq 2$ percent). Historically, $739,700 \mathrm{~km}^{2}(285,600$ $\mathrm{mi}^{2}$ ) of grasslands occurred in patches larger than $5,000 \mathrm{~km}^{2}\left(1,931 \mathrm{mi}^{2}\right)$. $\left(\mathrm{km}^{2}\right.$, square kilometer; $\mathrm{mi}^{2}$, square mile) 

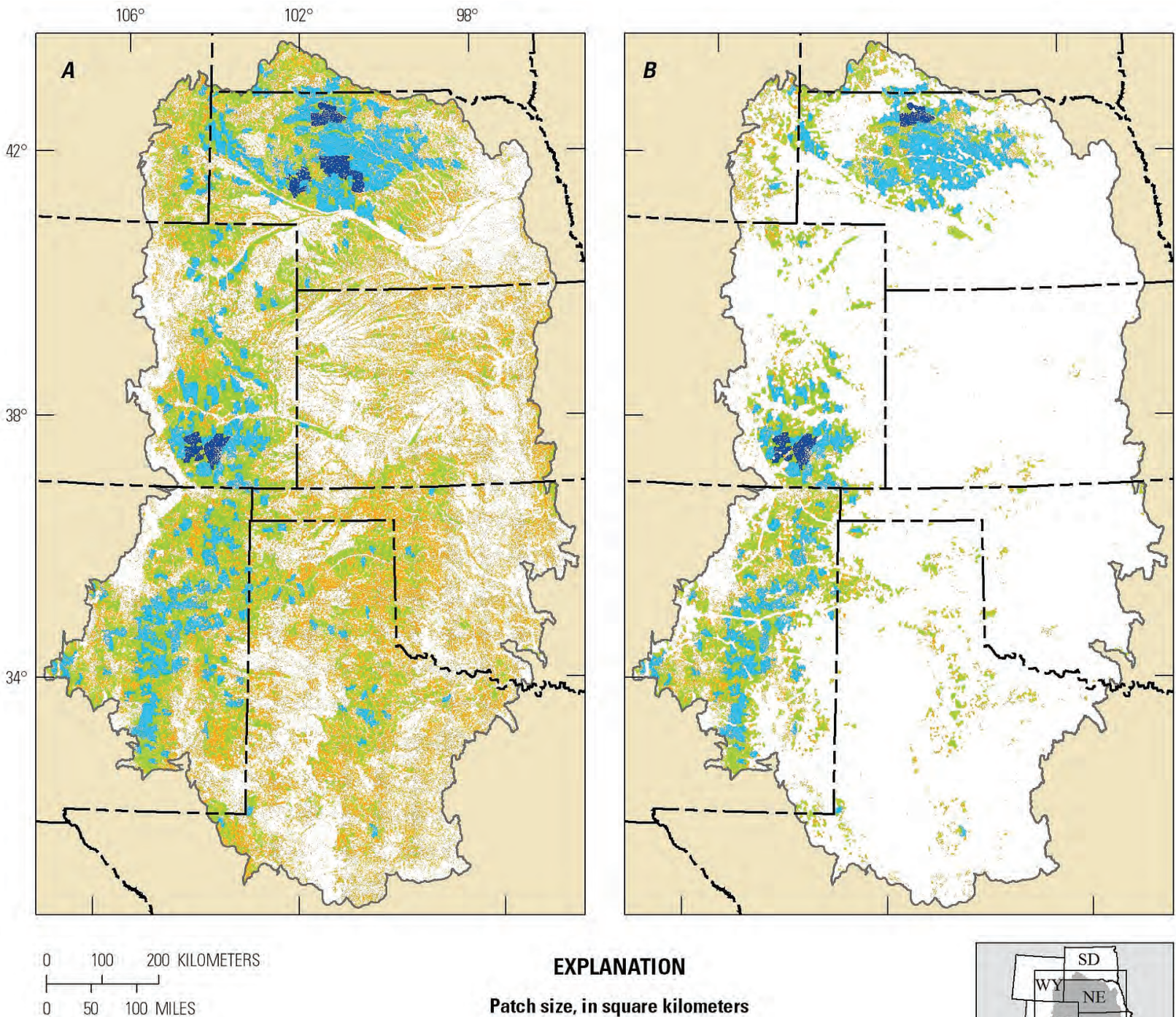

\section{EXPLANATION}

Patch size, in square kilometers
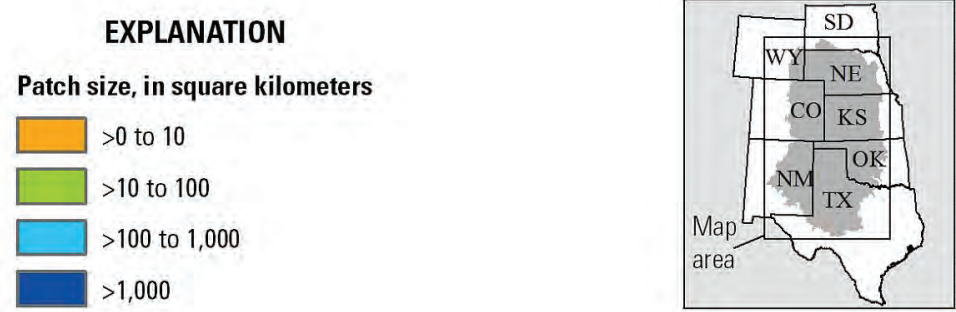

Figure 4-6. Patch size of grasslands in the Southern Great Plains. $A$, Baseline distribution. $B$, Relatively undeveloped areas (terrestrial development index score $\leq 2$ percent). 
Where are grasslands potentially vulnerable to honey mesquite and eastern redcedar expansion (fig. 4-7)?

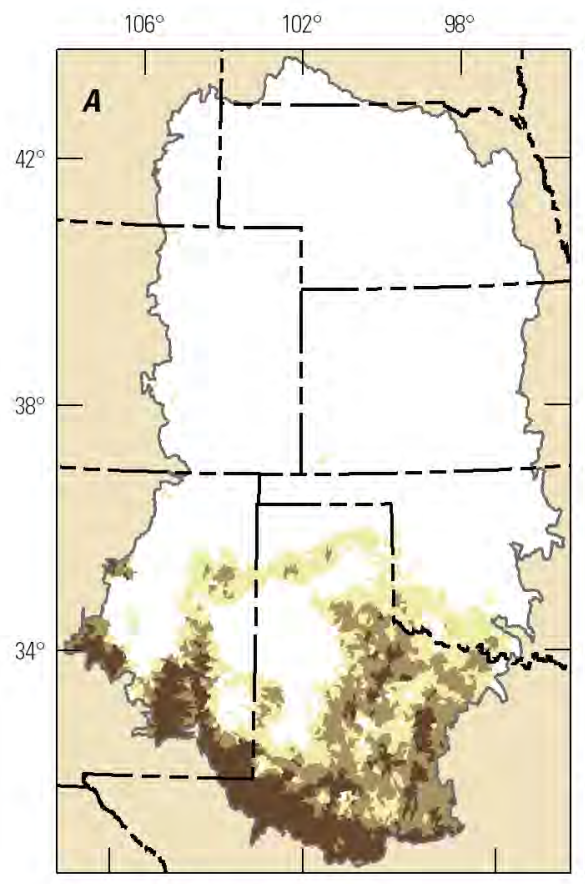

$0 \quad 100200$ KILOMETERS $\stackrel{1}{1}$ $0 \quad 50100$ MILES

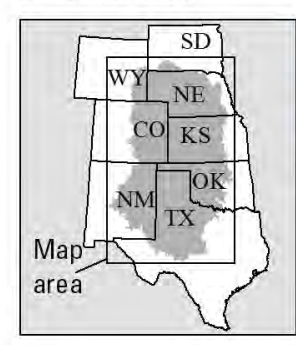

$>70$

$>35$ to 70

$\square>5$ to 35

$\square 0$ to 5

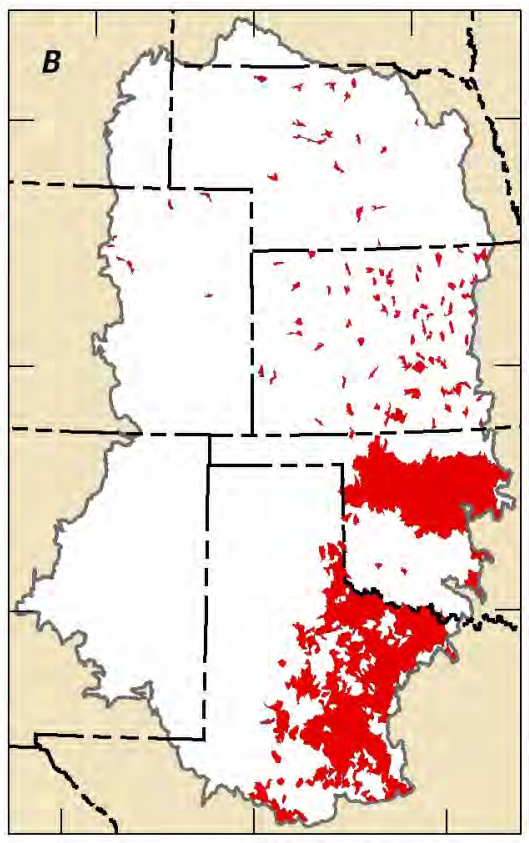

EXPLANATION

\section{B. Eastern redcedar}

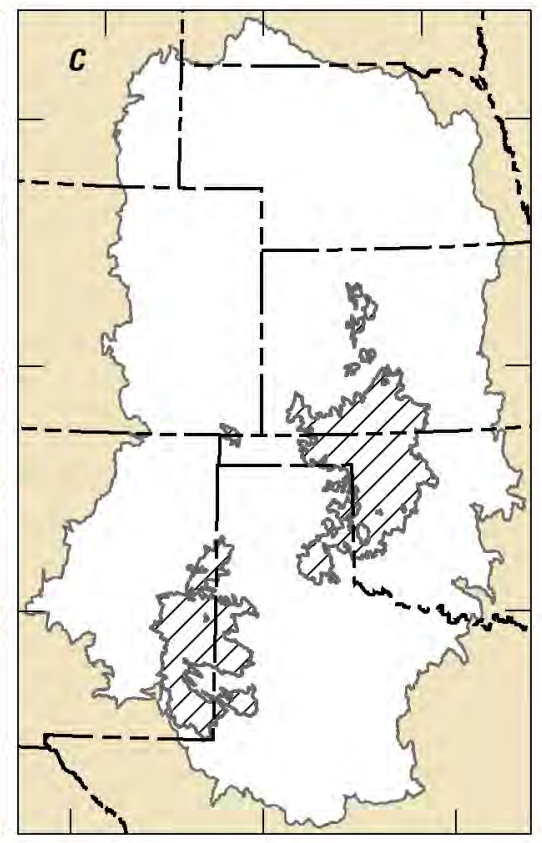

C. Either species

$\square \triangle$ Honey mesquite or eastern redcedar

Reported occurence

No reported occurences

Figure 4-7. Occurrences of $(A)$ honey mesquite, $(B)$ eastern redcedar, and $(C)$ either species, summarized by sixth-level watershed, in the Southern Great Plains. Cross-hatching represents areas with greater than 1 percent cover of honey mesquite and (or) eastern redcedar. 
Where are grasslands potentially vulnerable to projected climate change (fig. 4-8)?
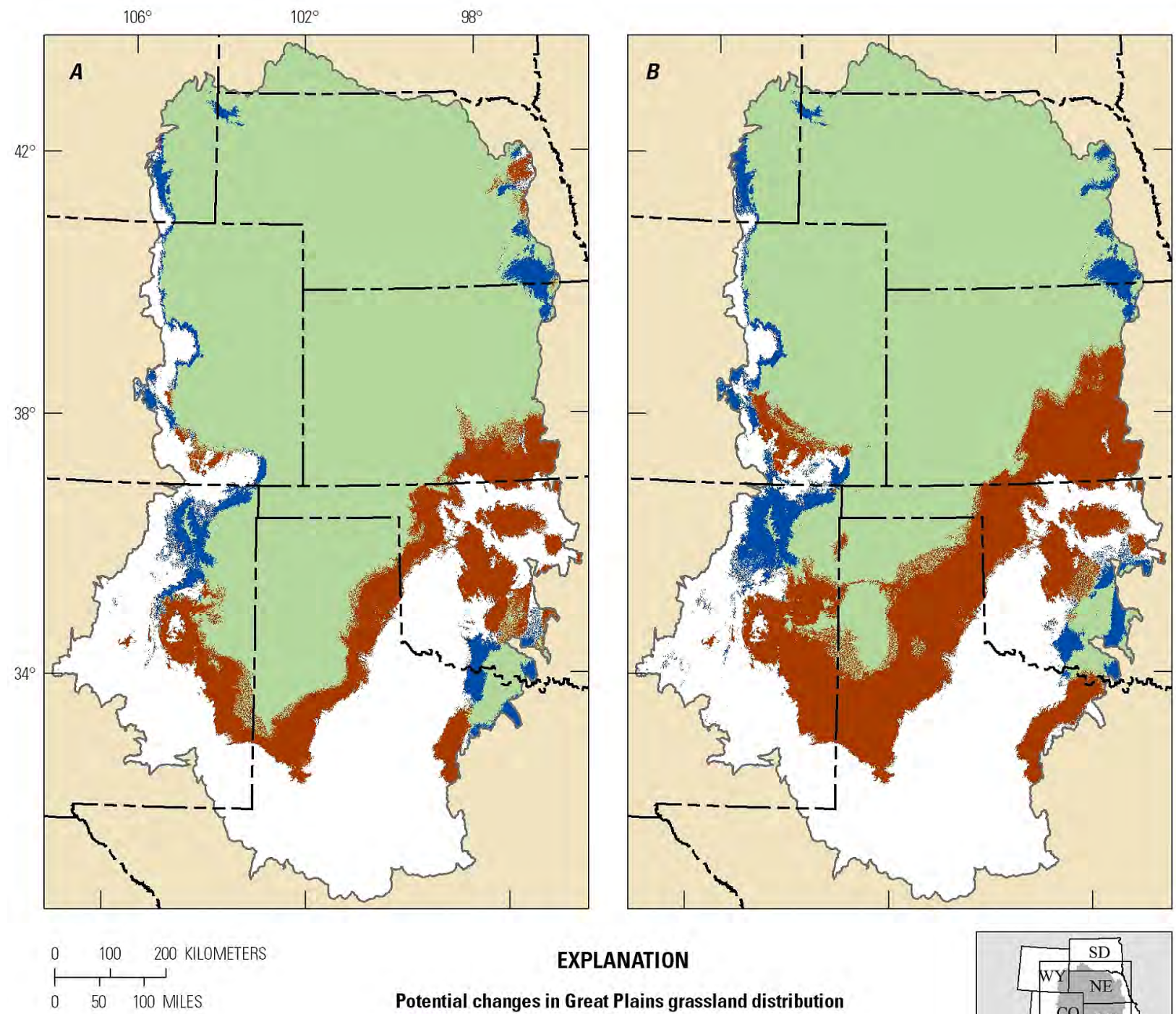

\section{EXPLANATION}

Potential changes in Great Plains grassland distribution
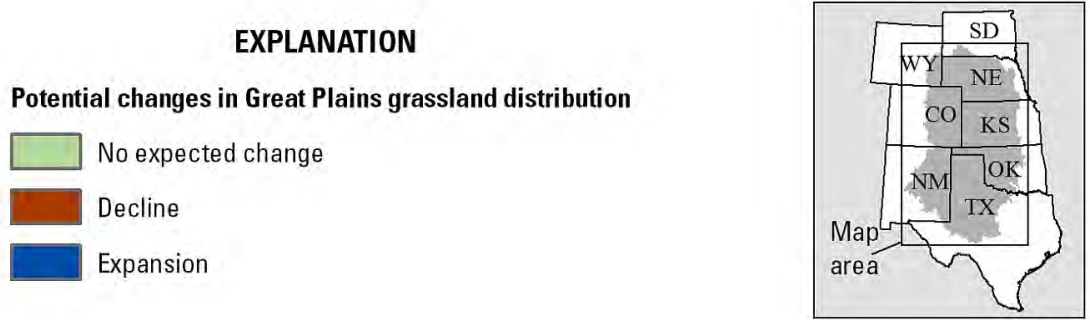

Figure 4-8. Potential changes in grasslands distribution as projected by climate change scenarios in the Southern Great Plains. The potential distribution is based on the bioclimatic envelope for Great Plains grassland developed by Rehfeldt and others (2012) for $(A) 2030$ and $(B) 2060$. 
Where are the grasslands with the highest overall landscape-level rank (fig. 4-9)?

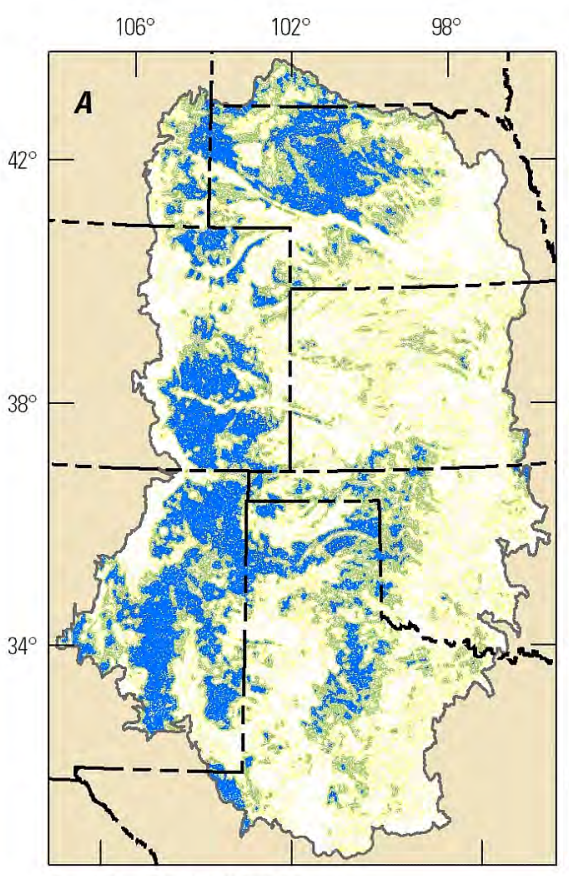

$0 \quad 100200$ KILOMETERS $\longmapsto 1,1$

$0 \quad 50100$ MILES

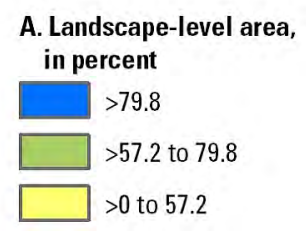

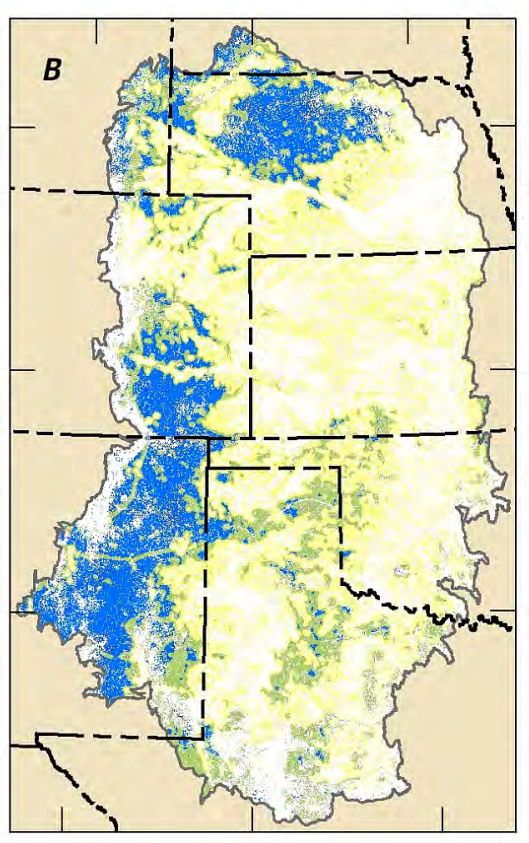

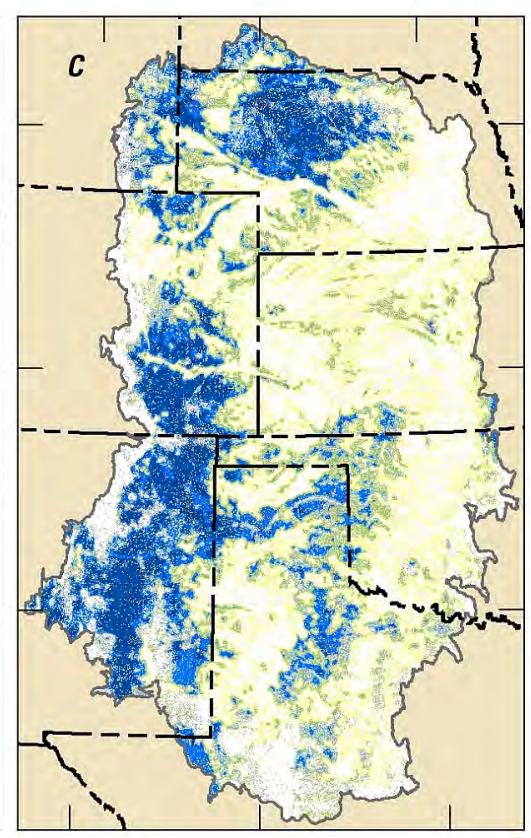

EXPLANATION

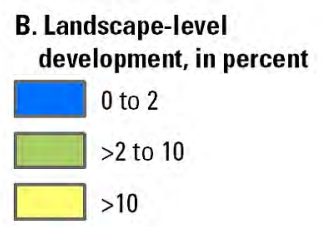

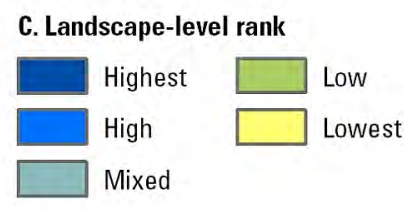

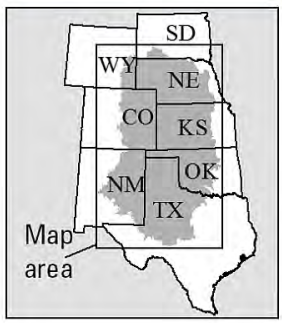

Figure 4-9. Landscape-level summaries for grasslands in the Southern Great Plains. Overall landscape-level rank $(C)$ is derived from $(A)$ landscape-level area and $(B)$ landscape-level development, summarized by a 5-kilometer-radius (3.11-mileradius) moving window (see table 4-3). Highest overall landscape-level rank corresponds to the largest landscape-level area and the lowest landscape-level development. Lowest overall landscape-level rank corresponds to the smallest landscapelevel area and highest landscape-level development. Landscape-level ranks are not intended as standalone summaries and are best interpreted in conjunction with the geospatial datasets used to address core management questions. 


\section{Summary}

- Grasslands were once widely distributed and connected, totaling an estimated 84 percent of the SGP (fig. 4-1). Historically, the more than 809,000 square kilometers $\left(\mathrm{km}^{2} ; 312,357\right.$ square miles $\left.\left[\mathrm{mi}^{2}\right]\right)$ of SGP grassland comprised a mosaic of shortgrass prairie, mixed-grass prairie, and other grasslands (cool-season bunchgrass prairie, foothill grassland, northwest mixed-grass prairie, saline grassland, sand prairie, semidesert grassland and shrubland, and tallgrass prairie).

- Within the SGP, approximately 43 percent of the estimated historical distribution of grasslands has been converted by development. Grasslands currently account for approximately 48 percent of the SGP. Mixed-grass prairie largely occurs in the eastern portions, sand prairie is scattered throughout but concentrated in the Nebraska Sand Hills at the northern extent, and shortgrass prairie is primarily in the western potions (fig. 4-2). Agricultural conversion is the dominant land use affecting grasslands. Because of data limitations, grasslands in the Conservation Reserve Program were not evaluated as a part of the Southern Great Plains Rapid Ecoregional Assessment (REA); Conservation Reserve Program lands may represent additional grasslands that were not mapped as grasslands for the REAs.

- Nearly one-third of remaining grasslands is relatively undeveloped (terrestrial development index [TDI] score $\leq 2$ percent) (figs. 4-3 and 4-4), but approximately 18 percent has very high levels of development (TDI score $>35$ percent). Development has greatly fragmented and decreased connectivity throughout much of the SGP. Historically, the majority of grasslands occurred in very large patches on the landscape, but currently, the largest grassland patches occur in shortgrass prairie and in the Nebraska Sand Hills (fig. 4-6A). Most patches of relatively undeveloped grasslands are $<1,000 \mathrm{~km}^{2}$ (386 min) (fig. 4-6B).

- Watersheds with honey mesquite and eastern redcedar are broadly distributed across the southern and eastern portions of the SGP (fig. 4-7). Eastern redcedar is expanding westward, and widespread occurrence in tallgrass prairie directly east of the SGP indicates the potential for additional expansion. Honey mesquite is expanding both within and outside of its historical range in southern portions of the SGP.
- Bioclimatic conditions conducive to grasslands (excluding semidesert grassland and shrubland) are projected to remain throughout much of the SGP through at least 2060, indicating low vulnerability to the climate change scenarios evaluated. The greatest vulnerability to climate change is projected to occur in the southern portions of the SGP, where conditions suitable for semidesert grassland and shrubland are projected to expand northward (fig. 4-8). In addition, expansion of honey mesquite may be favored by projected climate changes.

- The greatest overall landscape-level ranks (where landscape-level area is largest and landscape-level development is lowest) occur in the western portion of the SGP and northern Nebraska (fig. 4-9C). Because a considerable proportion of the grasslands are grazed by livestock, additional local-level information on grazing is necessary to evaluate conditions in these areas.

\section{References Cited}

Assal, T.J., Melcher, C.P., and Carr, N.B., eds., 2015, Southern Great Plains Rapid Ecoregional AssessmentPre-assessment report: U.S. Geological Survey Open-File Report 2015-1003, 284 p., accessed September 2015 at https://doi.org/10.3133/ofr20151003.

Bragg, T.B., and Steuter, A.A., 1996, Prairie ecology-The mixed prairie, in Samson, F.B., and Knopf, F.L., eds., Prairie conservation-Preserving North America's most endangered ecosystem: Washington, D.C., Island Press, p. 53-66.

Chaney, Ed; Elmore, Wayne; and Platts, W.S., 1990, Livestock grazing on western riparian areas: U.S. Environmental Protection Agency, prepared by Northwest Resource Information Center, Inc., Eagle, Idaho, 45 p.

Conner, Richard; Seidl, Andrew; Van Tassell, Larry; and Wilkins, Neal, 2001, United States grasslands and related resources-An economic and biological trends assessment: College Station, Tex., Texas A\&M Institute of Renewable Natural Resources, 154 p., accessed September 18, 2016, at https:/irnr.tamu.edu/publications/research-reports/2001/ united-states-grasslands-and-related-resources-an-economic-and-biological-trends-assessment.

Derner, J.D., Lauenroth, W.K., Stapp, Paul, and Augustine, D.J., 2009, Livestock as ecosystem engineers for grassland bird habitat in the western Great Plains of North America: Rangeland Ecology and Management, v. 62, p. 111-118. 
Engle, D.M., Bidwell, T.G., and Moseley, M.E., 1996, Invasion of Oklahoma rangelands and forests by eastern red cedar and ashe juniper: Stillwater, Okla., Oklahoma State University, Cooperative Extension Service Circular E-947, $12 \mathrm{p}$.

Glaser, Aviva, ed., 2012, America's grasslands conference-Status, threats, and opportunities. The first Biennial Conference on the Conservation of America's Grasslands, Sioux Falls, S. Dak., August 14-17, Proceedings: National Wildlife Federation and South Dakota State University, 92 p., accessed September 18, 2016, at https://www.nwf. org/pdf/Policy-Solutions/Americas\%20Grasslands $\% 20$ Conference\%20Proceedings061312.pdf.

Knight, D.H., Jones, G.P., Reiners, W.A., and Romme, W.H., 2014, Grasslands, chap. 6 of Mountains and plains-The ecology of Wyoming landscapes ( $2 \mathrm{~d}$ ed.): New Haven, Conn., Yale University Press, p. 83-108.
Mutel, C.F., and Emerick, J.C., 1984, From grassland to glacier-The natural history of Colorado: Boulder, Colo., Johnson Books, $238 \mathrm{p}$.

Rehfeldt, G.E., Crookston, N.L., Sáenz-Romero, Cuauhtémoc, and Campbell, E.M., 2012, North American vegetation model for land-use planning in a changing climate-A solution to large classification problems: Ecological Applications, v. 22, no. 1, p. 119-141.

Samson, F.B., and Knopf, F.L., 1994, Prairie conservation in North America: BioScience, v. 44, p. 418-421.

Shiflet, T.N., ed., 1994, Rangeland cover types of the United States: Denver, Colo., Society for Range Management, 152 p.

Weaver, T., Payson, E.M., and Gustafson, D.L., 1996, Prairie ecology-The shortgrass prairie, in Samson, F.B., and Knopf, F.L., eds., Prairie conservation - Preserving North America's most endangered ecosystem: Washington, D.C., Island Press, p. 67-76. 


\section{Chapter 5. Mixed-Grass Prairie}

\section{Introduction}

In the Southern Great Plains (SGP), mixed-grass prairie (including midgrass prairie) primarily occurs from southcentral Nebraska to north-central Texas. This community forms a transition zone between shortgrass prairie to the west and tallgrass prairie to the east. The boundaries between grassland communities can shift in response to the region's highly variable cycles of drought and wetter periods (Samson and Knopf, 1996; Knight and others, 2014). Codominant plants in mixed-grass prairie include blue (Bouteloua gracilis) and sideoats (Bouteloua curtipendula) gramas, western wheatgrass (Pascopyrum smithii), and little (Schizachyrium scoparium) and big (Andropogon gerardii) bluestems. Forbs may represent up to 25 percent of the annual biomass and contribute to overall plant diversity (Bragg and Steuter, 1996).

Historically, primary disturbances in mixed-grass prairie were fire and herbivory, which removed fine fuels, suppressed woody species, and recycled nutrients (Bragg and Steuter, 1996). Other animal activities, including burrowing and trampling, and local site factors such as soil type and topographic features also affected patchiness and community diversity (Limb and others, 2011; Winter and others, 2011). The extent and frequency of these factors, as well as their interactive effects, contributed to the patchy vegetation structure and shifting dynamics of mixed-grass prairie. Periods of drought and wetter periods also contribute to patch dynamics. Tall

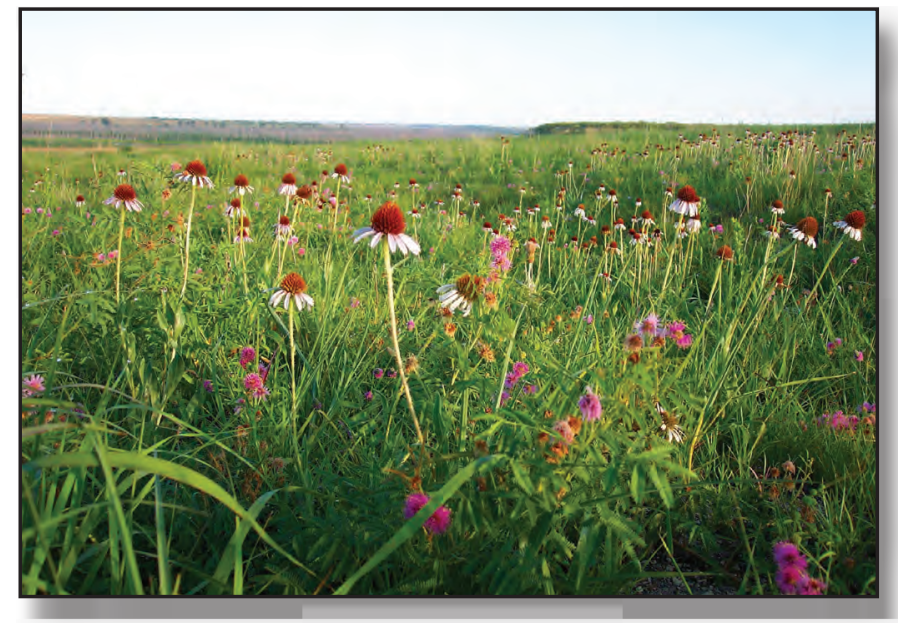

Kirwin National Wildlife Refuge, Kansas. Photograph by Tony Ifland, U.S. Fish and Wildlife Service (Creative Commons Attribution 2.0 Generic). grasses and less drought-tolerant mid-height grasses typically dominate in mesic conditions, but short grasses and droughttolerant mid-height grasses may become dominant during drier conditions and drought (Bragg and Steuter, 1996). Trees and shrubs may become dominant where landscape features reduce fire frequency, preclude large herbivores, and promote greater moisture availability (Bragg and Steuter, 1996). In turn, the patchy nature of the mixed-grass prairie historically supported a diversity of wildlife, including six species evaluated in the SGP Rapid Ecoregional Assessment: ferruginous hawk, lesser prairie chicken, burrowing owl, black-tailed prairie dog, swift fox, and mule deer.

Change agents in the mixed-grass prairie include agriculture and altered fire and herbivory disturbance regimes (Brudvig and others, 2007; Winter and others, 2011). Irrigation for agriculture has led to redistribution of surface water and decreased groundwater levels. Introductions of nonnative species and fire suppression, which can lead to expansion of honey mesquite in the southern portion of the SGP, have altered plant communities (Ansley and others, 2001). More recently, energy development, urbanization, development of extensive transportation corridors, and associated invasions or expansions of exotic species have further altered the structure and dynamics of mixed-grass prairie (Bragg and Steuter, 1996; Ansley and others, 2001). Additional background information can be found in the SGP pre-assessment report (Assal and others, 2015).

\section{Rapid Ecoregional Assessment Components Evaluated for Mixed-Grass Prairie}

The key ecological attributes and change agents addressed by core management questions for mixed-grass prairie include amount and distribution, landscape structure (patch size), and development (tables 5-1 and 5-2). Invasive woody species and climate change were evaluated for all grassland types (see chapter 4, "Grasslands"). Fire occurrence and potentially altered vegetation (including invasive herbaceous plants) were evaluated for the entire SGP (see chapter 3, "Change Agents"). Overall landscape-level ranking variables are summarized in table $5-3$. The core and integrated management questions are listed in table 5-4. 
Table 5-1. Key ecological attributes and associated indicators used to address core management questions for mixed-grass prairie for the Southern Great Plains Rapid Ecoregional Assessment.

\begin{tabular}{lll}
\hline \multicolumn{1}{c}{ Attributes } & Variables & \multicolumn{1}{c}{ Indicators $^{\mathbf{1}}$} \\
\hline Amount and distribution & Total area & Estimated historical and baseline distributions ${ }^{2}$ of mixed-grass prairie \\
Landscape structure & Patch size & Patch sizes for estimated historical and baseline distributions of mixed-grass prairie \\
Landscape dynamics & Fire occurrence & See chapter 3, "Change Agents" \\
\hline \multicolumn{2}{l}{ 'See chapter 2, "Methods Overview," and appendix A for methods and datasets used. } \\
${ }^{2}$ Baseline distribution is determined by the most current regional data available.
\end{tabular}

Table 5-2. Anthropogenic change agents and associated indicators used to address core management questions for mixed-grass prairie for the Southern Great Plains Rapid Ecoregional Assessment.

[km, kilometer; mi, mile]

\begin{tabular}{|c|c|c|}
\hline Change agents & Variables & Indicators $^{1}$ \\
\hline \multirow[t]{2}{*}{ Development } & Terrestrial development index & $\begin{array}{l}\text { Percentage of mixed-grass prairie in seven development classes based on a } 2.5-\mathrm{km} \\
(1.55-\mathrm{mi}) \text { moving window }\end{array}$ \\
\hline & Index of fragmentation & Patch sizes for relatively undeveloped ${ }^{2}$ mixed-grass prairie \\
\hline Climate change & Potential distribution of grasslands & See chapter 4, "Grasslands" \\
\hline
\end{tabular}

${ }^{1}$ See chapter 2, "Methods Overview," and appendix A for methods and datasets used.

${ }^{2}$ Terrestrial development index score less than or equal to 2 percent.

Table 5-3. Landscape-level variables used to address the integrated management question for mixed-grass prairie. Ranks for landscape-level area and development were combined into an overall landscape-level rank for the Southern Great Plains Rapid Ecoregional Assessment.

[>, greater than; km, kilometer; mi, mile]

\begin{tabular}{|c|c|c|c|c|}
\hline \multirow{2}{*}{$\begin{array}{c}\text { Landscape- } \\
\text { level variables }{ }^{1}\end{array}$} & \multirow{2}{*}{ Description } & \multicolumn{3}{|c|}{ Relative rank ${ }^{2}$} \\
\hline & & Lowest & Medium & Highest \\
\hline
\end{tabular}

${ }^{1}$ See chapter 2, "Methods Overview," and appendix A for methods and datasets used.

${ }^{2}$ Ranking breakpoints for area of mixed-grass prairie were determined from equal subsets of the data. Ranking breakpoints for terrestrial development index scores were standardized for all terrestrial conservation elements.

Table 5-4. Management questions addressed for mixed-grass prairie for the Southern Great Plains Rapid Ecoregional Assessment.

\begin{tabular}{l}
\hline \multicolumn{1}{c}{ Core management questions } \\
\hline What is the baseline distribution of mixed-grass prairie, and where has it been converted by development?
\end{tabular}

${ }^{1}$ See chapter 11, "Data Gaps, Limitations, and Uncertainty," for management questions that could not be addressed.

${ }^{2}$ See table 5-3. 


\section{Management Questions and Results}

What is the baseline distribution of mixed-grass prairie, and where has it been converted by development (fig. 5-1)?

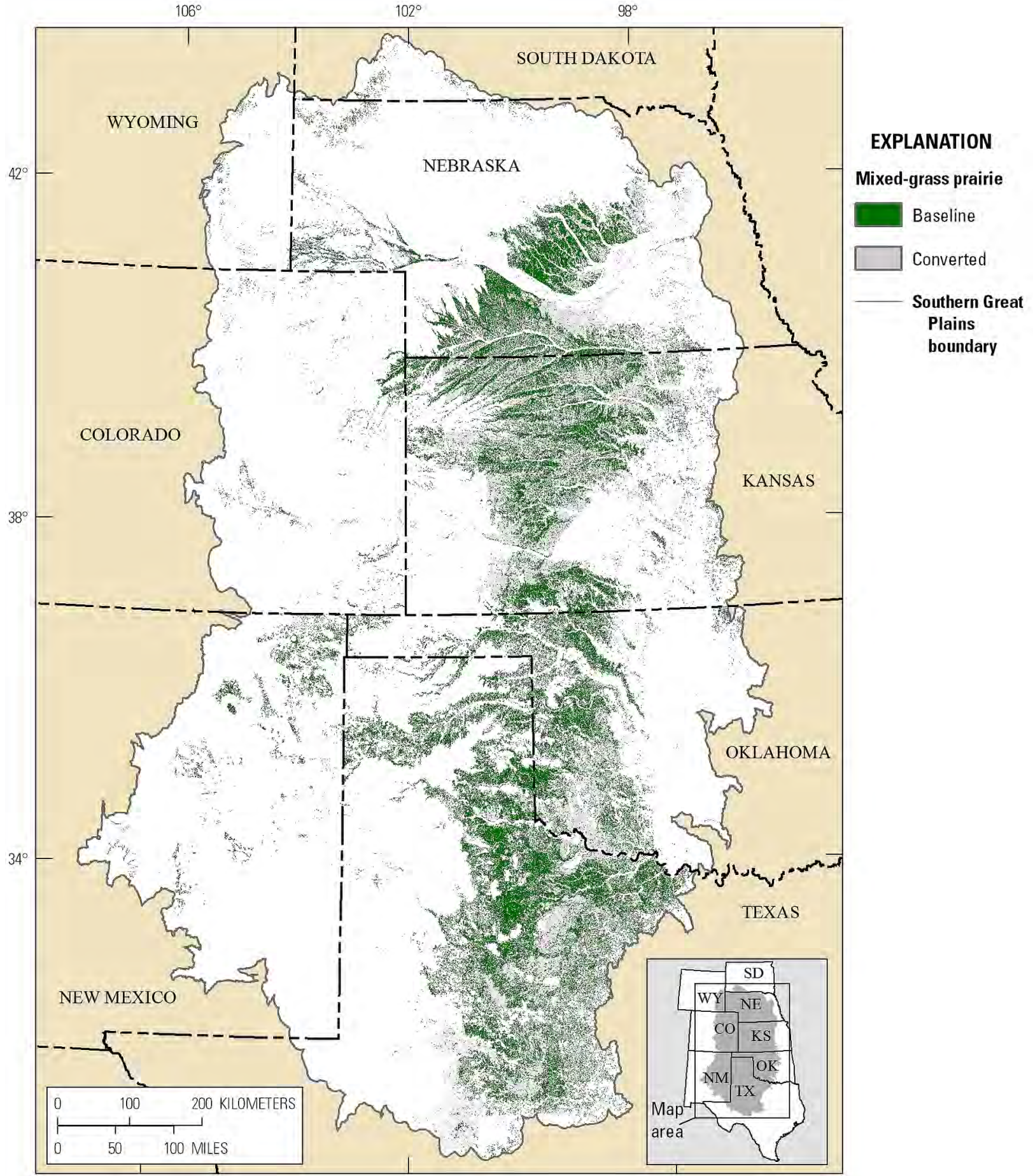

Figure 5-1. Baseline and converted historical distributions of mixed-grass prairie in the Southern Great Plains. 
Where does existing development pose the greatest threat to mixed-grass prairie, and where are the large, relatively undeveloped areas (figs. 5-2 and 5-3)?

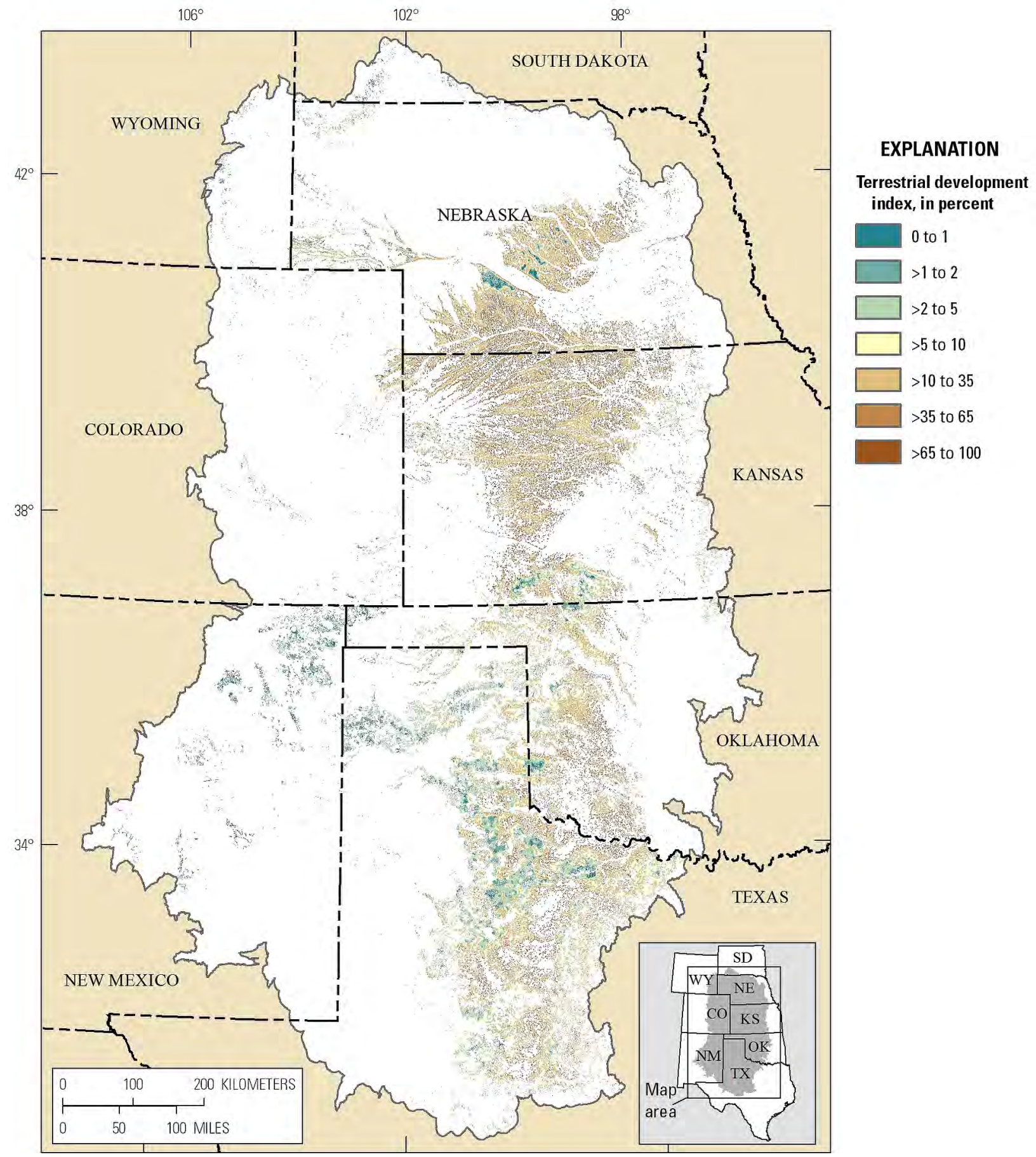

Figure 5-2. Terrestrial development index for baseline mixed-grass prairie in the Southern Great Plains. 


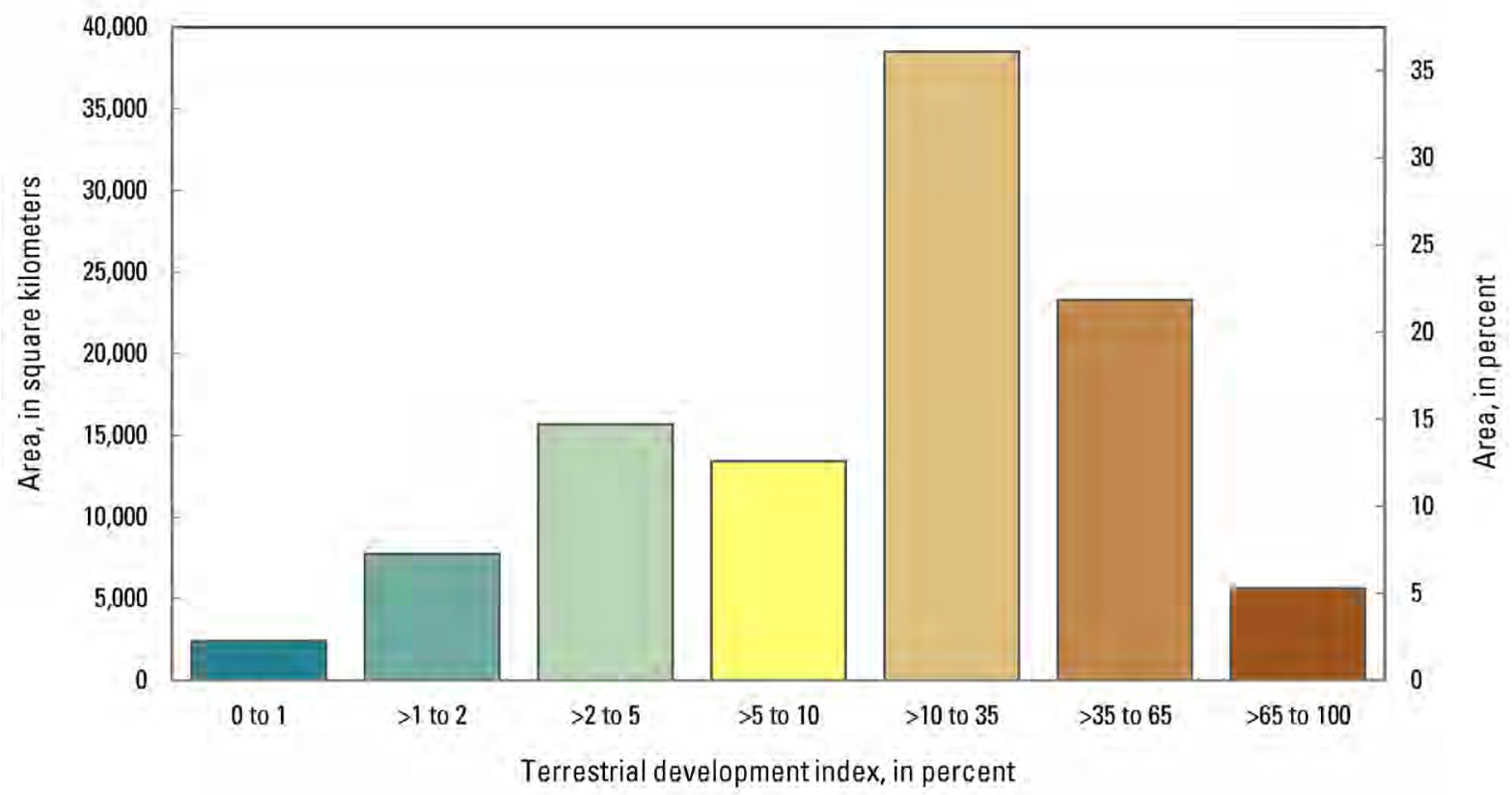

Figure 5-3. Area of baseline mixed-grass prairie by terrestrial development index class in the Southern Great Plains.

How has development fragmented mixed-grass prairie (figs. 5-4 and 5-5)?

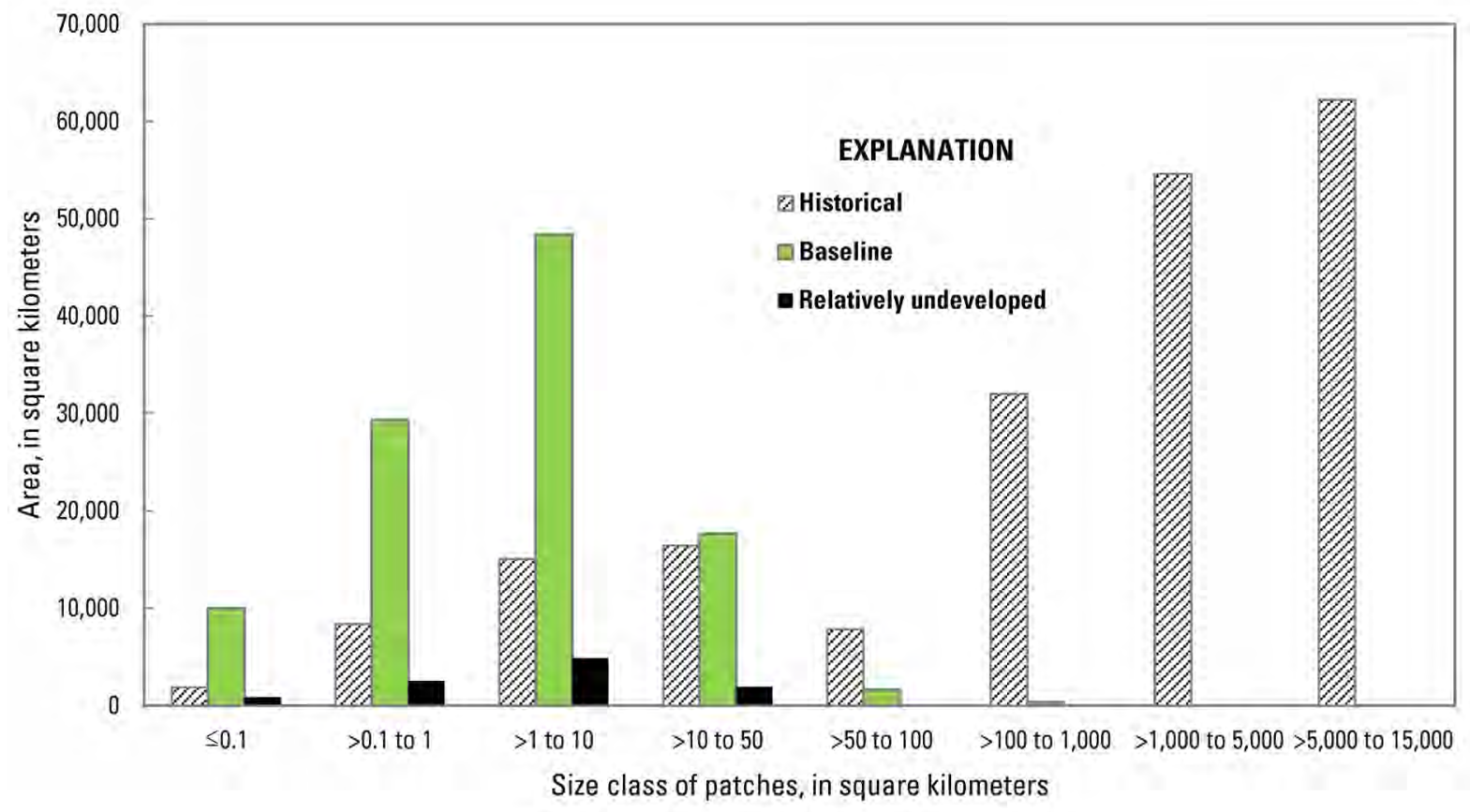

Figure 5-4. Area of mixed-grass prairie in the Southern Great Plains as a function of patch size for historical, baseline, and relatively undeveloped conditions (terrestrial development index score $\leq 2$ percent). 

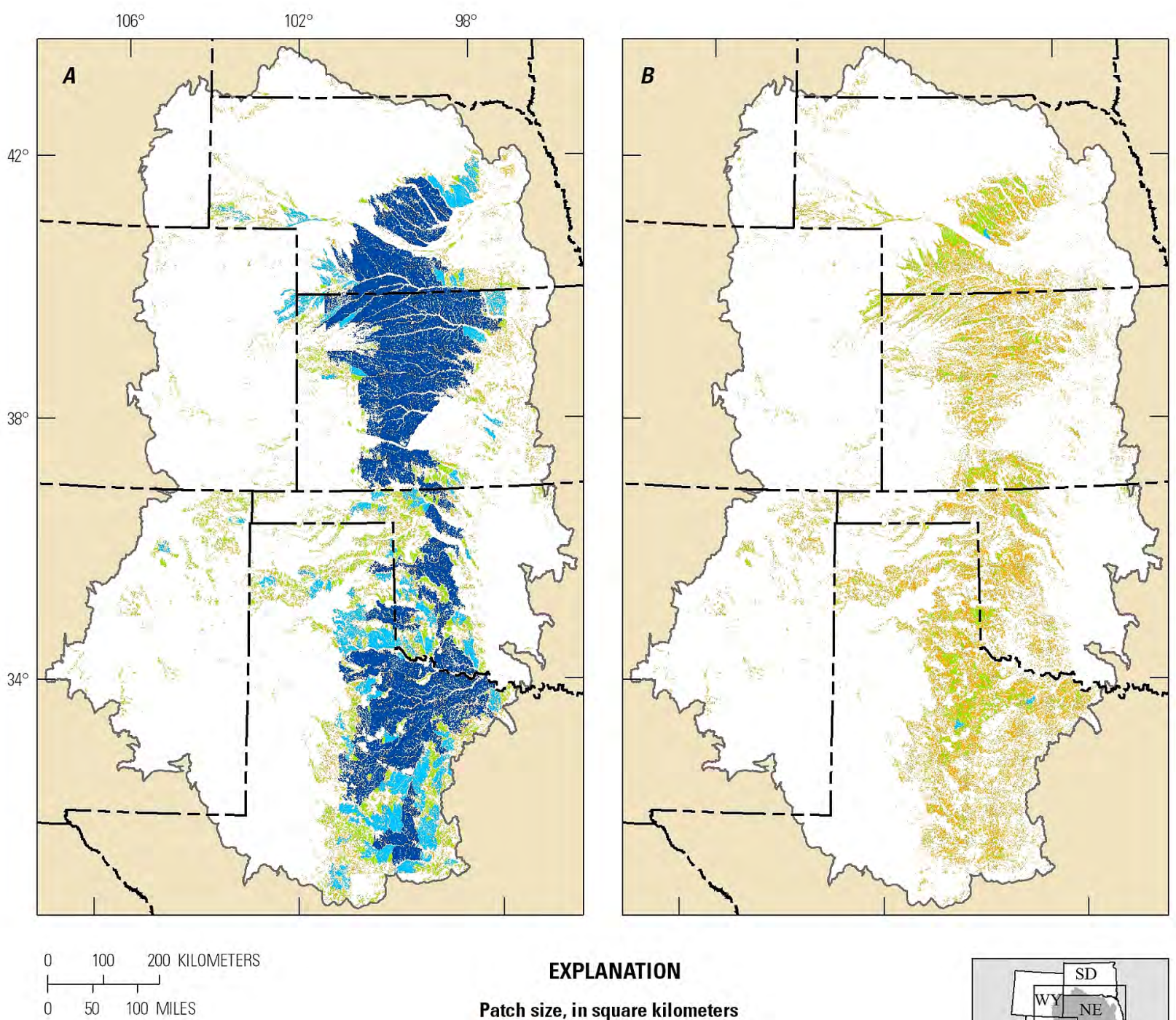

\section{EXPLANATION}

Patch size, in square kilometers
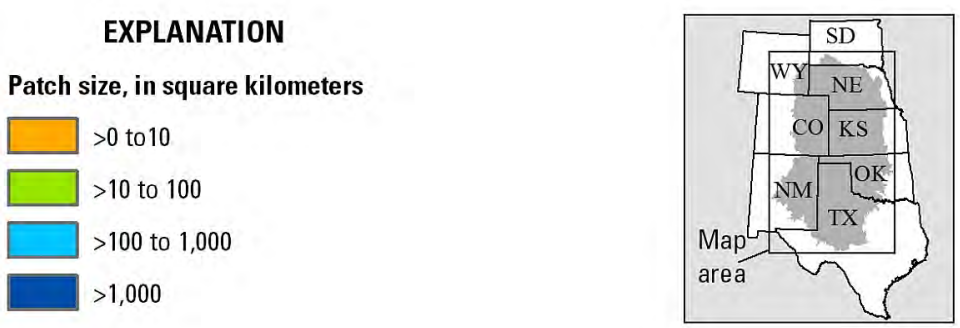

Figure 5-5. Patch size of mixed-grass prairie in the Southern Great Plains. $A$, Estimated historical distribution. $B$, Baseline distribution. 
Where are the mixed-grass prairies with the highest overall landscape-level rank (fig. 5-6)?

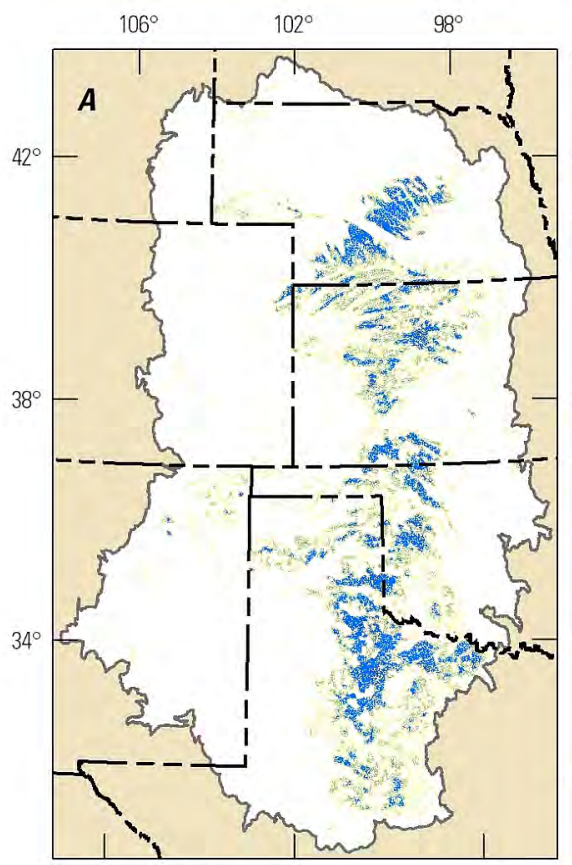

$0 \quad 100200$ KILOMETERS $\mapsto I_{1}$

$0 \quad 50100$ MILES
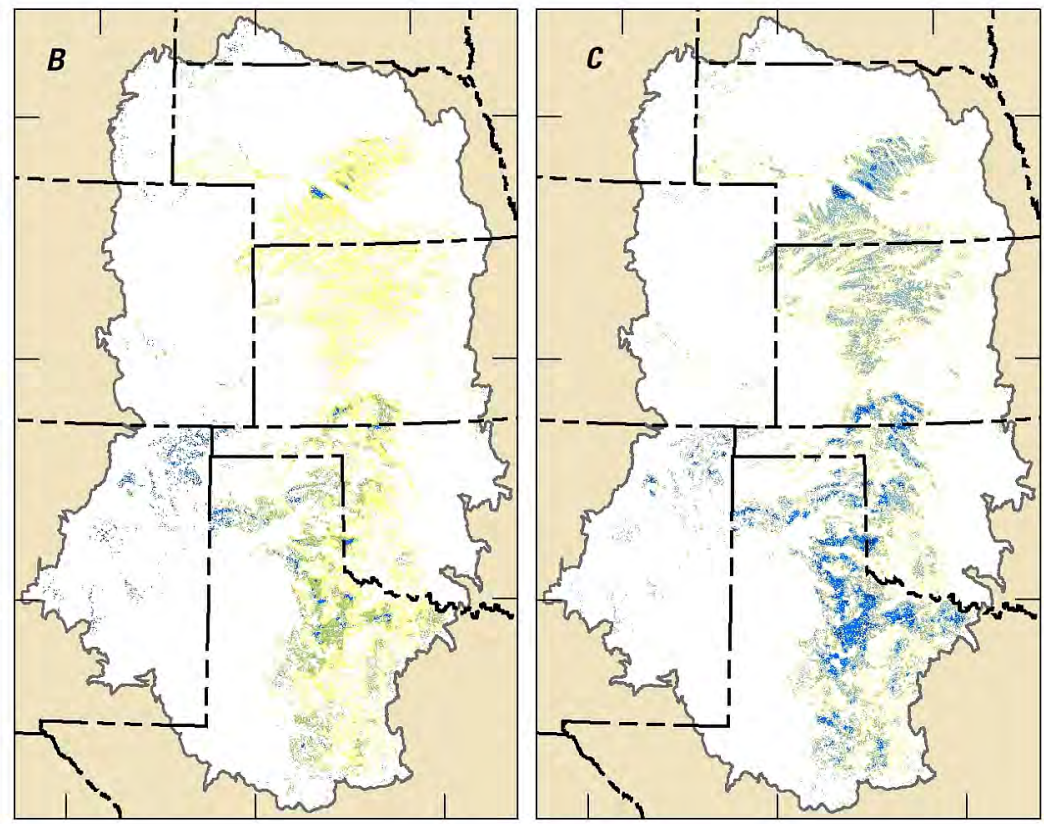

EXPLANATION

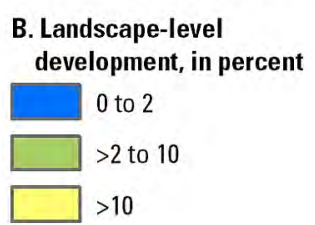

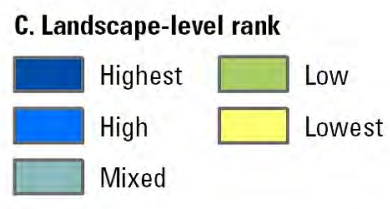

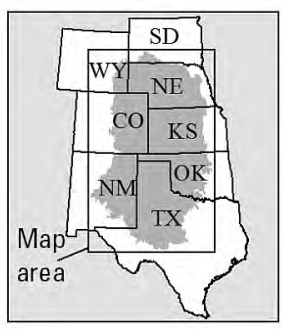

Figure 5-6. Landscape-level summaries for mixed-grass prairie in the Southern Great Plains. Overall landscape-level rank $(C)$ is derived from $(A)$ landscape-level area and $(B)$ landscape-level development, summarized by a 5-kilometerradius (3.11-mile-radius) moving window (see table $5-3$ ). Highest overall landscape-level rank corresponds to the largest landscape-level area and the lowest landscape-level development. Lowest overall landscape-level rank corresponds to the smallest landscape-level area and highest landscape-level development. Landscape-level ranks are not intended as standalone summaries and are best interpreted in conjunction with the geospatial datasets used to address core management questions. 


\section{Summary}

- Historically, mixed-grass prairie covered more than 20 percent of the SGP and formed a heterogeneous mosaic with shortgrass and tallgrass prairie (fig. 5-1).

- Agricultural and other development have converted much of the mixed-grass prairie. Approximately 107,350 square kilometers $\left(\mathrm{km}^{2} ; 41,448\right.$ square miles $\left[\mathrm{mi}^{2}\right]$ ) remain, representing less than 55 percent of the estimated historical distribution (fig. 5-1).

- Only 9.5 percent of mixed-grass prairie is relatively undeveloped (terrestrial development index [TDI] score $\leq 2$ percent), and approximately 14 percent has low development levels (TDI scores 2-5 percent) (figs. 5-2 and 5-3). More than 27 percent has very high levels of development (TDI scores $>35$ percent).

- Development has greatly fragmented and decreased connectivity of mixed-grass prairie. Nearly 59 percent of the estimated historical mixed-grass prairie occurred in patches $>1,000 \mathrm{~km}^{2}\left(386 \mathrm{mi}^{2}\right)$, whereas most remaining patches are $<10 \mathrm{~km}^{2}\left(4 \mathrm{mi}^{2}\right)$ (figs. 5-4 and 5-5). The largest patches remaining are in Nebraska and Texas (fig. 5-5).

- Most of the remaining mixed-grass prairie (fig. 5-6A) occurs in areas with high development levels (fig. 5-6B). The locations surrounded by the largest amounts of mixed-grass prairie and lowest amounts of development (highest overall landscape-level ranks) are relatively small and are scattered throughout the SGP (fig. 5-6C).

\section{References Cited}

Ansley, R.J., Wu, X.B., and Kramp, B.A., 2001, Observation-Long-term increases in mesquite canopy cover in a north Texas savanna: Journal of Range Management, v. 54, p. $171-176$.

Assal, T.J., Melcher, C.P., and Carr, N.B., eds., 2015, Southern Great Plains Rapid Ecoregional AssessmentPre-assessment report: U.S. Geological Survey Open-File Report 2015-1003, 284 p., accessed September 2015 at https://doi.org/10.3133/ofr20151003.

Bragg, T.B., and Steuter, A.A., 1996, Prairie ecology-The mixed prairie, in Samson, F.B., and Knopf, F.L., eds., Prairie conservation-Preserving North America's most endangered ecosystem: Washington, D.C., Island Press, p. 53-66.

Brudvig, L.A., Mabry, C.M., Miller, J.R., and Walker, T.A., 2007, Evaluation of central North American prairie management based on species diversity, life form, and individual species metrics: Conservation Biology, v. 21, no. 3, p. 864-874.

Knight, D.H., Jones, G.P., Reiners, W.A., and Romme, W.H., 2014, Grasslands, chap. 6 of Mountains and plains-The ecology of Wyoming landscapes ( $2 \mathrm{~d}$ ed.): New Haven, Conn., Yale University Press, p. 83-108.

Limb, R.F., Fuhlendorf, S.D., Engle, D.M., Weir, J.R., Elmore, R.D., and Bidwell, T.G., 2011, Pyric-herbivory and cattle performance in grassland ecosystems: Rangeland Ecology and Management, v. 64, p. 659-663.

Samson, F.B., and Knopf, F.L., eds., 1996, Prairie conservation-Preserving North America's most endangered ecosystem: Washington, D.C., Island Press, 339 p.

Winter, S.L., Fuhlendorf, S.D., Goad, C.L., Davis, C.A., and Hickman, K.R., 2011, Topoedaphic variability and patch burning in sand sagebrush shrubland: Rangeland Ecology and Management, v. 64, p. 633-640. 


\section{Chapter 6. Shortgrass Prairie}

\section{Introduction}

In the Southern Great Plains (SGP), shortgrass prairie occurs in southeastern Wyoming and southwestern Nebraska, eastern Colorado and New Mexico, the western counties of Kansas, and the panhandles and rolling plains of Oklahoma and Texas. The codominant plants are blue grama (Bouteloua gracilis) and buffalograss (Bouteloua dactyloides), which characterize this community's short vertical structure. Historically, fire exerted a strong influence on the landscape structure and dynamics of shortgrass prairie (Ford and McPherson, 1996; Brockway and others, 2002) by setting back seral stages and releasing nutrients. Although poorly understood, fires may have occurred every 2-30 years, with longer fire-return intervals expected where fuels had less continuity (Knight and others, 2014). Other influential disturbances include drought, herbivory, and other activities of animals. After disturbances, there may be pulses of vegetative growth during wet years and after influxes of nutrients. Other important influences on landscape struture and dynamics of shortgrass prairie include heterogeneity in soil type and topography (Weaver and others, 1996; Limb and others, 2009; Knight and others, 2014). This

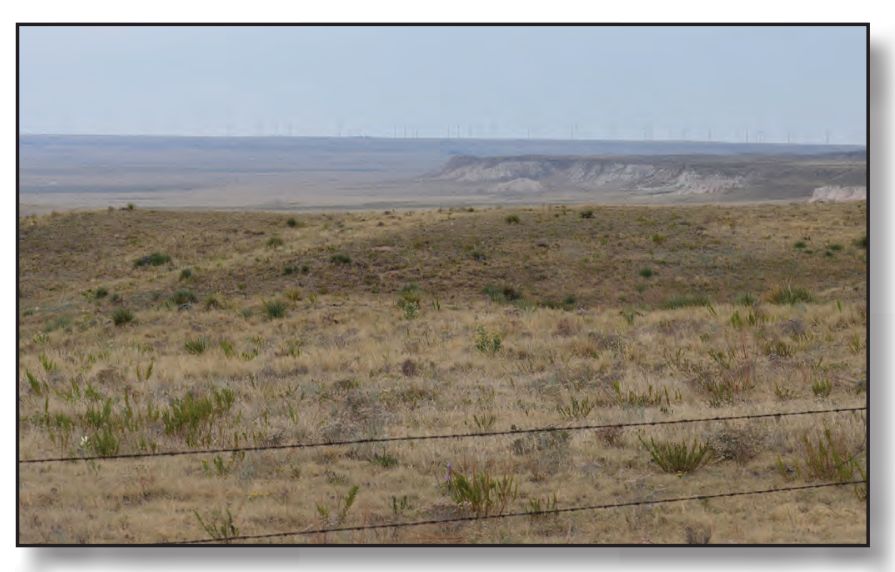

Pawnee Buttes, Colorado. Photograph by Natasha Carr, U.S. Geological Survey. combination of factors that influences shortgrass structure and dynamics creates a shifting mosaic that supports a rich diversity of plant and animal species (Ricketts and others, 1999), including five species addressed in the SGP Rapid Ecoregional Assessment: ferruginous hawk, lesser prairie chicken, longbilled curlew, burrowing owl, and swift fox.

Agriculture and livestock grazing are dominant land uses in the shortgrass prairie. High-intensity grazing practices, intensified crop rotations, and changes to the Conservation Reserve Program continue to alter the structure and dynamics of shortgrass landscapes. Recent expansion of wind, oil, and gas energy development are contributing to the direct habitat loss and fragmentation of shortgrass prairie. These human activities also may alter natural disturbance regimes, including fire and herbivory. Although honey mesquite historically occurred in the southernmost regions of the SGP, it has expanded and increased in abundance, presumably as a result of fire and livestock grazing (Dick-Peddie, 1993; Ansley and others, 2001). Additional background information can be found in the SGP pre-assessment report (Assal and others, 2015).

\section{Rapid Ecoregional Assessment Components Evaluated for Shortgrass Prairie}

The key ecological attributes and change agents addressed by core management questions for shortgrass prairie include amount and distribution, landscape structure (patch size), and development (tables 6-1 and 6-2). Invasive woody species and climate change were evaluated for all grassland types (see chapter 4, "Grasslands"). Fire occurrence and potentially altered vegetation (including invasive herbaceous plants) were evaluated for the entire SGP (see chapter 3, "Change Agents"). Overall landscape-level ranking variables are summarized in table $6-3$. The core and integrated management questions are listed in table $6-4$. 
Table 6-1. Key ecological attributes and associated indicators used to address core management questions for shortgrass prairie for the Southern Great Plains Rapid Ecoregional Assessment.

\begin{tabular}{lll}
\hline \multicolumn{1}{c}{ Attributes } & \multicolumn{1}{c}{ Variables } & \multicolumn{1}{c}{ Indicators $^{\mathbf{1}}$} \\
\hline Amount and distribution & Total area & Estimated historical and baseline distributions ${ }^{2}$ of shortgrass prairie \\
Landscape structure & Patch size & Patch sizes for estimated historical and baseline distributions of shortgrass prairie \\
Landscape dynamics & Fire occurrence & See chapter 3, "Change Agents" \\
\hline
\end{tabular}

${ }^{1}$ See chapter 2, "Methods Overview," and appendix A for methods and datasets used.

${ }^{2}$ Baseline distribution is determined by the most current regional data available.

Table 6-2. Anthropogenic change agents and associated indicators used to address core management questions for shortgrass prairie for the Southern Great Plains Rapid Ecoregional Assessment.

[km, kilometer; mi, mile]

\begin{tabular}{|c|c|c|}
\hline \multirow{2}{*}{$\begin{array}{l}\text { Change agents } \\
\text { Development }\end{array}$} & Variables & Indicators $^{1}$ \\
\hline & Index of fragmentation & Patch sizes for relatively undeveloped ${ }^{2}$ shortgrass prairie \\
\hline Climate change & Potential distribution of grasslands & See chapter 4, "Grasslands" \\
\hline
\end{tabular}

${ }^{1}$ See chapter 2, "Methods Overview," and appendix A for methods and datasets used.

${ }^{2}$ Terrestrial development index score less than or equal to 2 percent.

Table 6-3. Landscape-level variables used to address the integrated management question for shortgrass prairie. Ranks for landscape-level area and development were combined into an overall landscape-level rank for the Southern Great Plains Rapid Ecoregional Assessment.

[>, greater than; km, kilometer; mi, mile]

\begin{tabular}{|c|c|c|c|c|}
\hline \multirow{2}{*}{$\begin{array}{c}\text { Landscape- } \\
\text { level variables }\end{array}$} & \multirow{2}{*}{ Description } & \multicolumn{3}{|c|}{ Relative rank ${ }^{2}$} \\
\hline & & Lowest & Medium & Highest \\
\hline Area & Percentage of 5-km-radius (3.11-mi) moving window classified as baseline shortgrass prairie & $>0-43.2$ & $>43.2-68.4$ & $>68.4$ \\
\hline Development & $\begin{array}{l}\text { Mean terrestrial development index score for baseline shortgrass prairie within a } 5 \text {-km-radius } \\
\text { (3.11-mi) moving window }\end{array}$ & $0-2$ & $2-10$ & $>10$ \\
\hline
\end{tabular}

${ }^{1}$ See chapter 2, "Methods Overview," and appendix A for methods and datasets used.

${ }^{2}$ Ranking breakpoints for area of shortgrass prairie were determined from equal subsets of the data. Ranking breakpoints for terrestrial development index scores were standardized for all terrestrial conservation elements.

Table 6-4. Management questions addressed for shortgrass prairie for the Southern Great Plains Rapid Ecoregional Assessment.

\begin{tabular}{|c|c|}
\hline Core management questions ${ }^{1}$ & Results \\
\hline What is the baseline distribution of shortgrass prairie, and where has it been converted by development? & Figure 6-1 \\
\hline $\begin{array}{l}\text { Where does existing development pose the greatest threat to shortgrass prairie, and where are the large, relatively } \\
\text { undeveloped areas? }\end{array}$ & Figures $6-2$ and $6-3$ \\
\hline How has development fragmented shortgrass prairie? & Figures $6-4$ and $6-5$ \\
\hline Integrated management question ${ }^{2}$ & Results \\
\hline
\end{tabular}

${ }^{1}$ See chapter 11, "Data Gaps, Limitations, and Uncertainty," for management questions that could not be addressed.

${ }^{2}$ See table 6-3. 


\section{Management Questions and Results}

What is the baseline distribution of shortgrass prairie, and where has it been converted by development (fig. 6-1)?

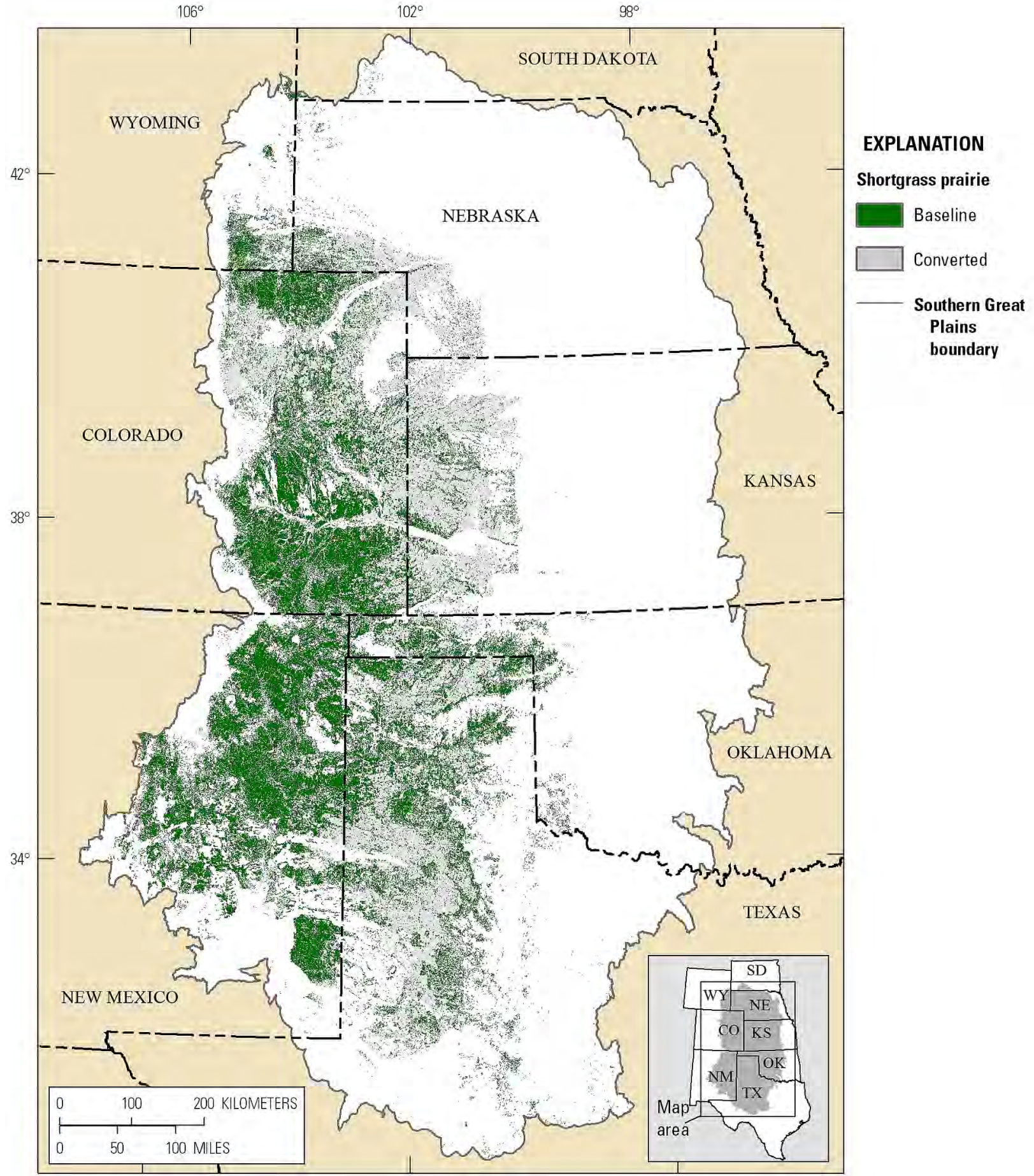

Figure 6-1. Baseline and converted historical distributions of shortgrass prairie in the Southern Great Plains. 
Where does existing development pose the greatest threat to shortgrass prairie, and where are the large, relatively undeveloped areas (figs. 6-2 and 6-3)?

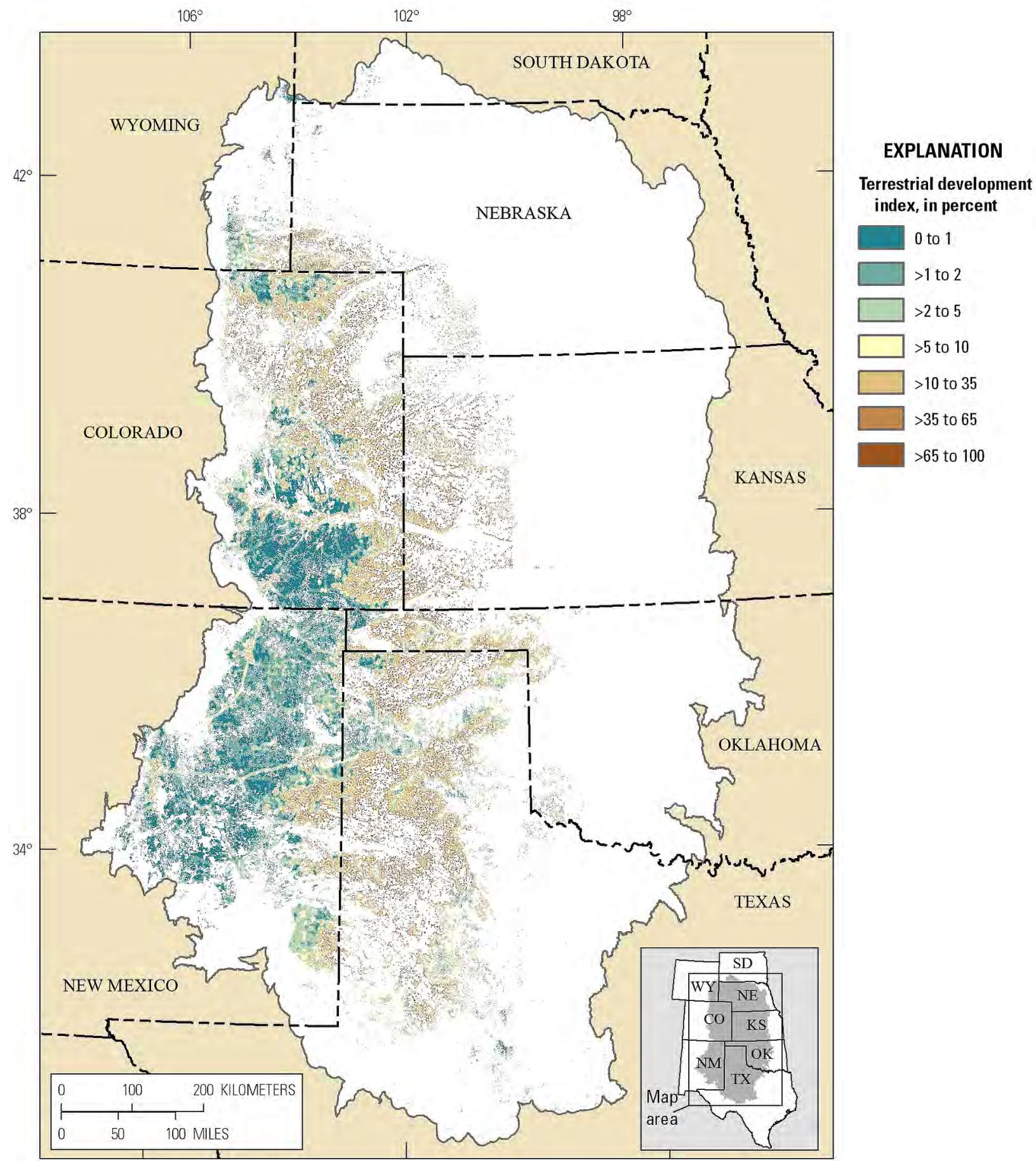

Figure 6-2. Terrestrial development index for baseline shortgrass prairie in the Southern Great Plains. 


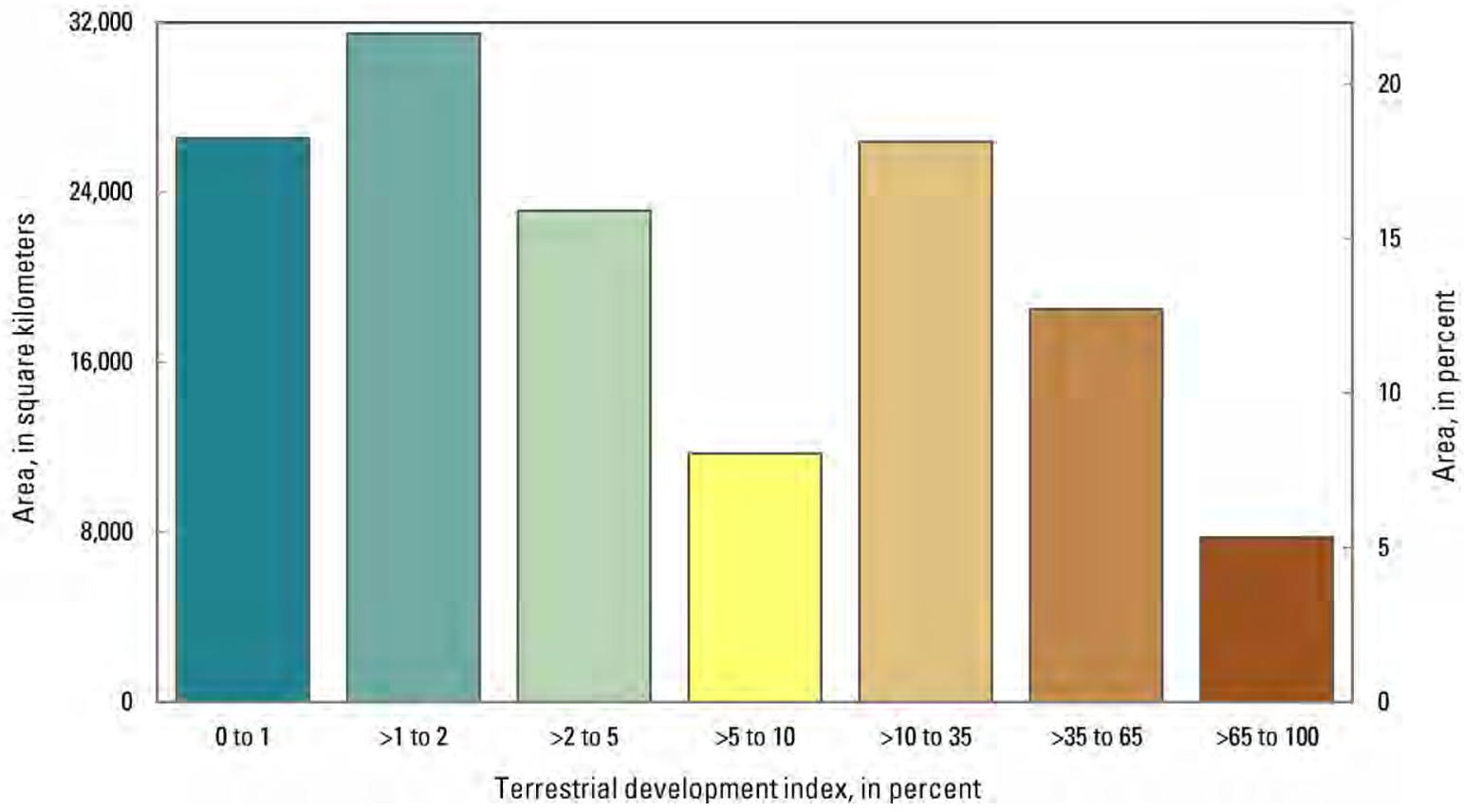

Figure 6-3. Area of baseline shortgrass prairie by terrestrial development index class in the Southern Great Plains.

How has development fragmented shortgrass prairie (figs. 6-4 and 6-5)?

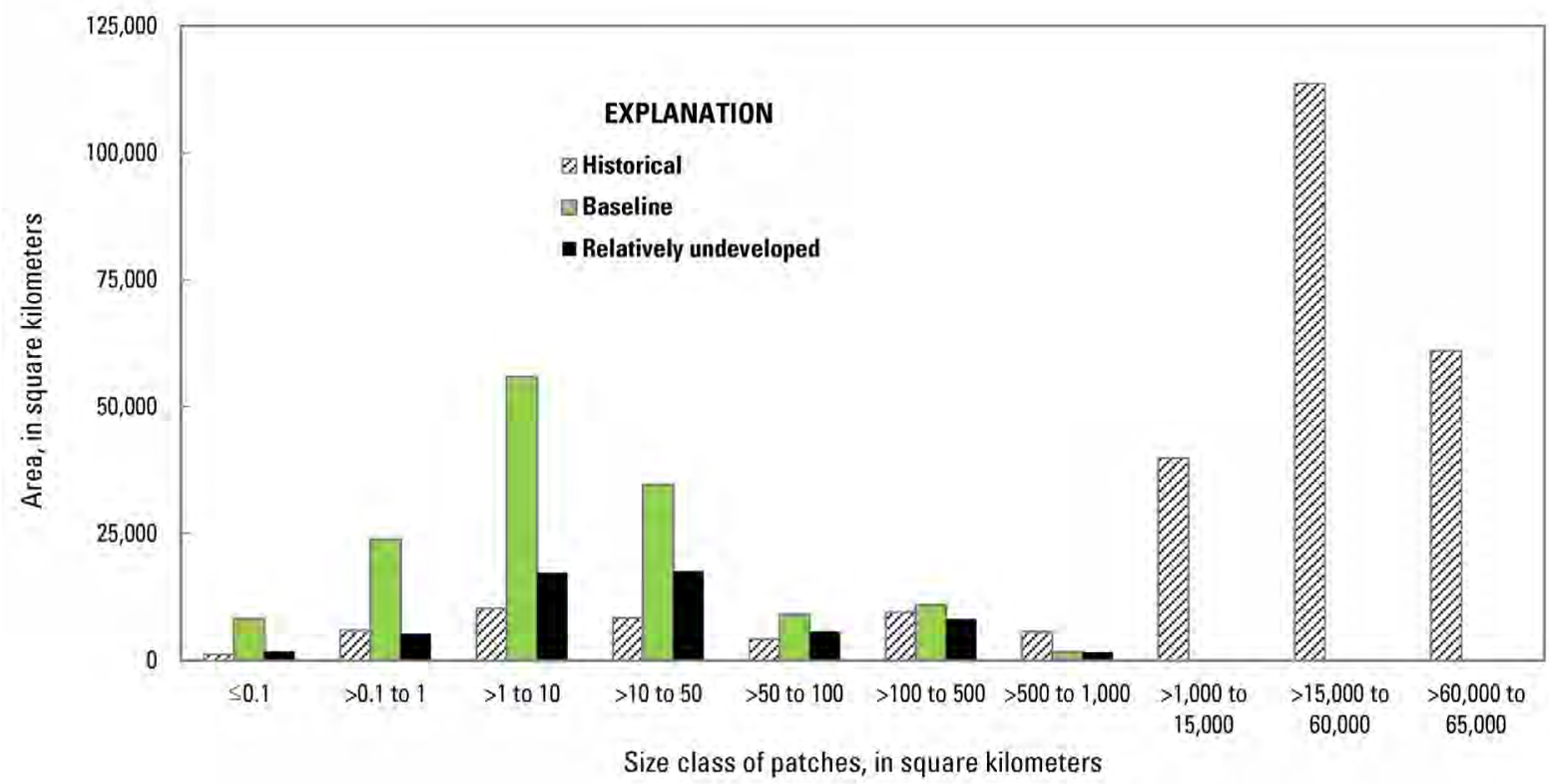

Figure 6-4. Area of shortgrass prairie in the Southern Great Plains as a function of patch size for historical, baseline, and relatively undeveloped conditions (terrestrial development index score $\leq 2$ percent). 

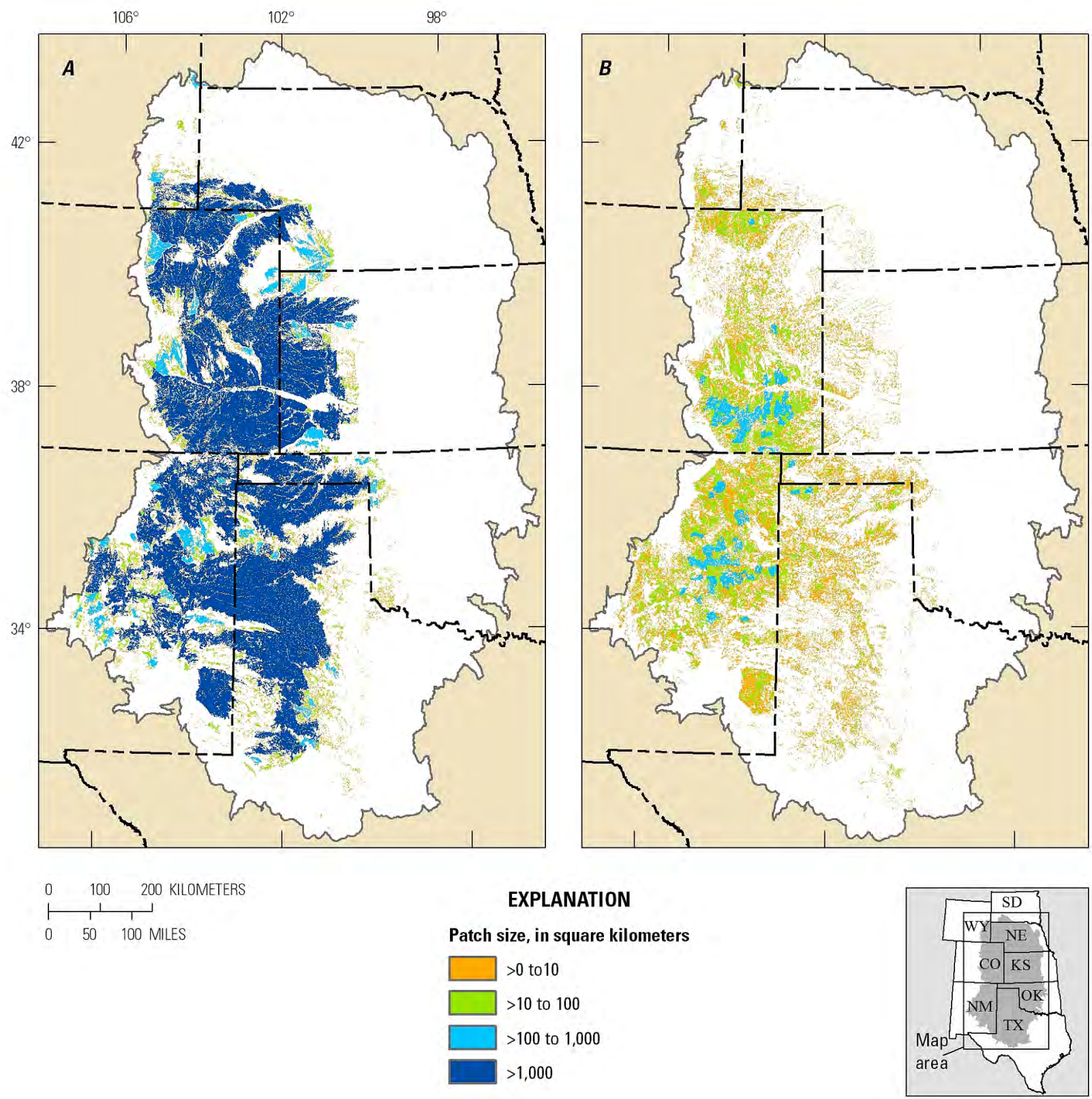

Figure 6-5. Patch size of shortgrass prairie in the Southern Great Plains. A, Estimated historical distribution. $B$, Baseline distribution. 
Where are the shortgrass prairies with the highest overall landscape-level rank (fig. 6-6)?

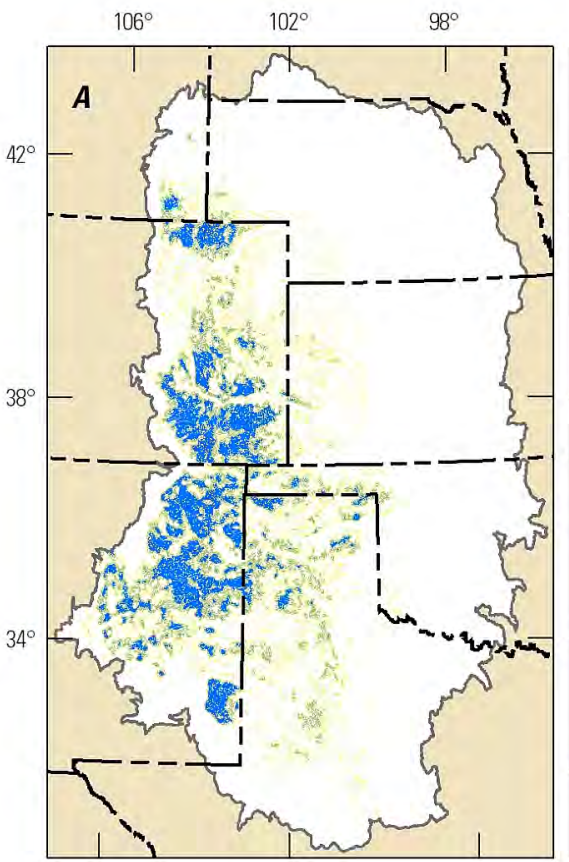

$0 \quad 100200$ KILOMETERS

$\longmapsto 1,1$

$0 \quad 50100$ MILES

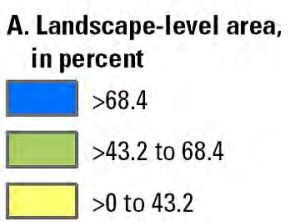

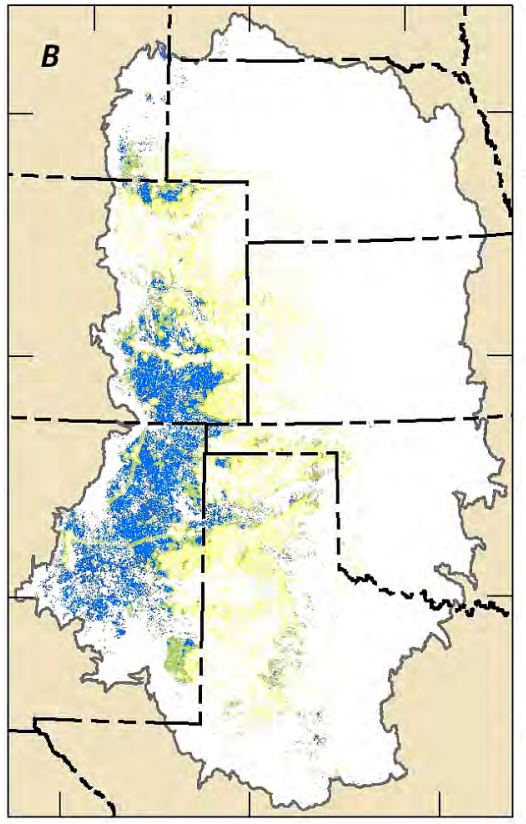

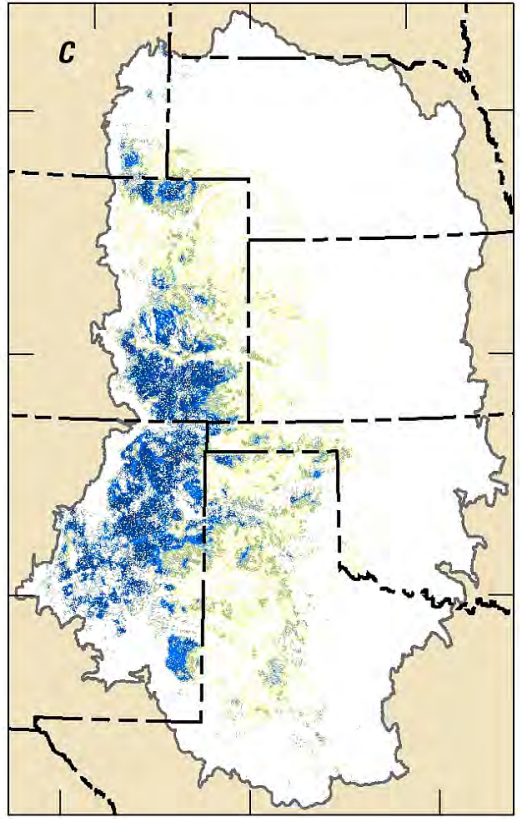

\section{EXPLANATION}

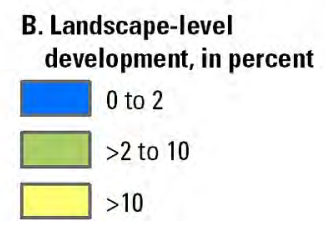

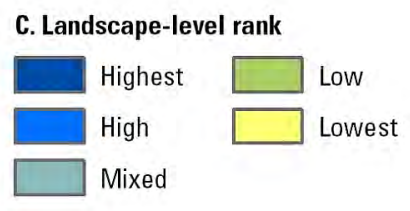

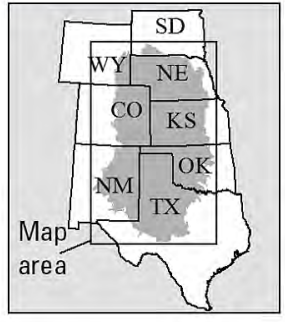

Figure 6-6. Landscape-level summaries for shortgrass prairie in the Southern Great Plains. Overall landscape-level rank $(C)$ is derived from $(A)$ landscape-level area and $(B)$ landscape-level development, summarized by a 5-kilometerradius (3.11-mile-radius) moving window (see table 6 -3). Highest overall landscape-level rank corresponds to the largest landscape-level area and the lowest landscape-level development. Lowest overall landscape-level rank corresponds to the smallest landscape-level area and highest landscape-level development. Landscape-level ranks are not intended as standalone summaries and are best interpreted in conjunction with the geospatial datasets used to address core management questions. 


\section{Summary}

- Historically, shortgrass prairie occupied more than 27 percent of the SGP, mostly in a large, relatively continuous band from southeast Wyoming to central Texas (fig. 6-1).

- Agricultural and other development have converted more than 44 percent of shortgrass prairie. Approximately 144,045 square kilometers $\left(\mathrm{km}^{2} ; 55,616\right.$ square miles $\left[\mathrm{mi}^{2}\right]$ ) of shortgrass prairie remain (fig. $6-1$ ).

- Approximately 40 percent of the remaining shortgrass prairie is relatively undeveloped (terrestrial development index [TDI] score $\leq 2$ percent), and nearly 16 percent has low development levels (TDI scores $2-5$ percent). Approximately 18 percent has very high development levels (TDI score $>35$ percent) (figs. 6-2 and 6-3).

- Development has greatly fragmented shortgrass prairie. Approximately 67 percent of the historical shortgrass prairie occurred in patches $>15,000 \mathrm{~km}^{2}\left(5,792 \mathrm{mi}^{2}\right)$, whereas 61 percent currently occurs in patches $<10 \mathrm{~km}^{2}$ $\left(4 \mathrm{mi}^{2}\right)$, and more than 91 percent of the total area is in patches $<100 \mathrm{~km}^{2}\left(39 \mathrm{mi}^{2}\right.$ ) (figs. 6-4 and 6-5).

- Conversion to agriculture and other development is lower in the western shortgrass prairie than along its eastern boundary, where it forms a mosaic with mixed-grass prairie. Consequently, the highest landscape-level ranks occur in eastern Colorado and New Mexico (fig. 6-6C).

\section{References Cited}

Ansley, R.J., Wu, X.B., and Kramp, B.A., 2001, Observation-Long-term increases in mesquite canopy cover in a north Texas savanna: Journal of Range Management, v. 54, p. 171-176.

Assal, T.J., Melcher, C.P., and Carr, N.B., eds., 2015, Southern Great Plains Rapid Ecoregional AssessmentPre-assessment report: U.S. Geological Survey Open-File Report 2015-1003, 284 p., accessed September 2015 at https://doi.org/10.3133/ofr20151003.
Brockway, D.G., Gatewood, R.G., and Paris, R.B., 2002, Restoring fire as an ecological process in shortgrass prairie ecosystems - Initial effects of prescribed burning during the dormant and growing seasons: Journal of Environmental Management, v. 65, p. 135-152.

Dick-Peddie, W.A., 1993, New Mexico vegetation-Past, present, and future: Albuquerque, N. Mex., University of New Mexico Press, 244 p.

Ford, P.L., and McPherson, G.R., 1996, Ecology of fire in shortgrass prairie of the Southern Great Plains, in Finch, D.M., ed., Ecosystem disturbance and wildlife conservation in western grasslands-A symposium proceedings, Albuquerque, N. Mex., September 22-26, 1994: Fort Collins, Colo., U.S. Department of Agriculture, Forest Service, Rocky Mountain Forest and Range Experiment Station, General Technical Report RM-GTR-285, p. 20-39.

Knight, D.H., Jones, G.P., Reiners, W.A., and Romme, W.H., 2014, Mountains and plains-The ecology of Wyoming landscapes ( $2 \mathrm{~d}$ ed.): New Haven, Conn., Yale University Press, $404 \mathrm{p}$.

Limb, R.F., Fuhlendorf, S.D., and Townsend, D.E., 2009, Heterogeneity of thermal extremes - Driven by disturbance of inherent in the landscape: Environmental Management, v. 43, p. $100-106$.

Ricketts T.H.; Dinerstein, Eric; Olson, D.M.; Louks, C.J.; Eichbaum, William; DellaSala, D.A.; Kavanaugh, Kevin; Hedao, Prashant; Hurley, Patrick; Carney, Karen; Abell, Robin; and Walters, Steven, 1999, Terrestrial ecoregions of North America-A conservation assessment: Washington, D.C., Island Press, 508 p.

Weaver, T., Payson, E.M., and Gustafson, D.L., 1996, Prairie ecology - The shortgrass prairie, in Samson, F.B., and Knopf, F.L., eds., Prairie conservation-Preserving North America's most endangered ecosystem: Washington, D.C., Island Press, p. 67-76. 


\section{Chapter 7. Sand Prairie}

\section{Introduction}

In the Southern Great Plains (SGP), sand prairie encompasses three plant associations: the Nebraska Sand Hills, sand sagebrush (Artemisia filifolia), and sand shinnery oak (Quercus havardii), a thicket-forming deciduous shrub. The sand hills are broadly distributed across the large dunes of north-central Nebraska and are characterized by a mix of mid-height and tall grasses (Weaver and Albertson, 1956). Outside of the sand hills, sand sagebrush occurs throughout much of the sand prairie, whereas sand shinnery oak (hereafter referred to as shinnery oak) occurs primarily south of Colorado and Kansas (Peterson and Boyd, 1998). Both sand sagebrush and shinnery oak occur on deep, sandy soils, often on small lunettes and sandy deposits broadly associated with paleo floodplains (Whitman and Barker, 1994; Peterson and Boyd, 1998; Colorado Natural Heritage Program, 2013). Sand sagebrush typically grows less than 1 meter (3 feet) high and accounts for up to 50 percent of the cover, whereas shinnery oak typically grows less than 2 meters ( 6 feet) high and accounts for up to 100 percent of the cover. The understory of sand sagebrush is generally dominated by short grasses, although mid-height grasses may dominate where conditions are more mesic (Weaver and Albertson, 1956). Shinnery oak is generally codominant with mid-height and tall grasses that may overtop the oak (Peterson and Boyd, 1998). Both species, which often co-occur, support biotic communities that differ from those of surrounding grasslands. In particular, they provide essential habitat for the dunes sagebrush lizard (Sceloporus arenicolus), western massasauga (Sistrurus catenatus tergeminus), and lesser prairie chicken, all of which are species of special concern in the SGP.

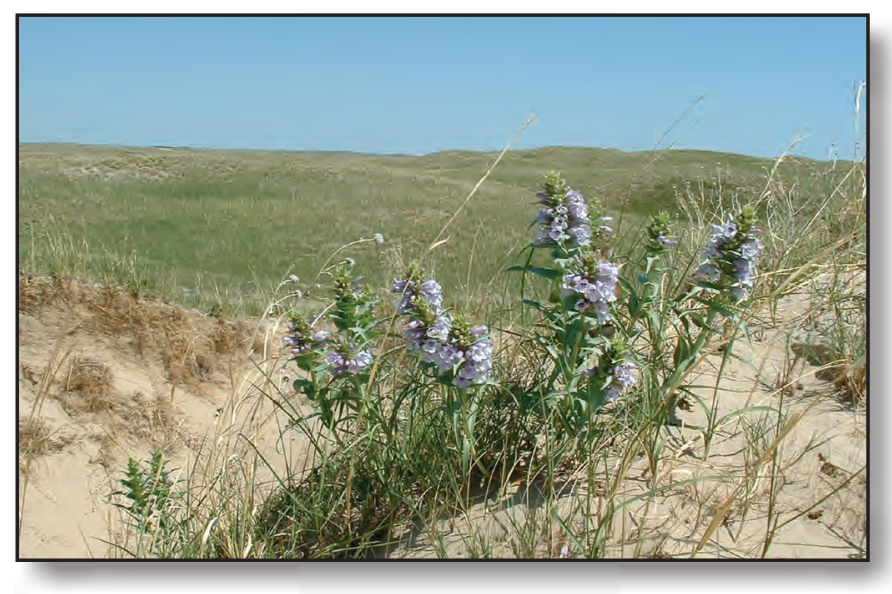

Sandhills, Nebraska. Photograph by Melvin Nenneman, U.S. Fish and Wildlife Service (Creative Commons Attribution 2.0 Generic).
Historically, the primary disturbances in the sand prairie were fire, herbivory and other animal activities, interactions between fire and grazing, drought, and wind (Stubbendieck and others, 1989; Peterson and Boyd, 1998; Winter and others, 2012). Fire and grazing promote increased productivity of sand prairie by removing litter and recycling nutrients. Where dunes are poorly vegetated, blowouts created by the interactive effects of grazing animals and wind erosion can occur (Stubbendieck and others, 1989), providing unique habitats for many rare species (for example, blowout penstemon [Penstemon haydenii]). It was once generally assumed that shinnery oak had recently expanded at the expense of grasslands, which led to decades of herbicide treatments and other management actions to kill or discourage shinnery oak. Although reducing shinnery oak cover can stimulate grass production in the short term, eradication may destabilize sandy soils. Furthermore, recent research indicates that shinnery oak systems have not expanded (Bragg and Steuter, 1996). Although shinnery oak responds well to disturbances that leave the roots largely intact, it does not readily expand into or recolonize recently disturbed areas. Altered fire regimes, energy development, urbanization, agricultural conversion, and certain livestock management practices have fragmented and contributed to the direct loss of sand prairie. Livestock grazing practices and loss of native herbivores often lead to shifts in community composition, such as increased shrub cover and decreased grass production (Colorado Natural Heritage Program, 2013). Additional background information can be found in the SGP pre-assessment report (Assal and others, 2015).

\section{Rapid Ecoregional Assessment Components Evaluated for Sand Prairie}

The key ecological attributes and change agents addressed by core management questions for sand prairie include amount and distribution, landscape structure (patch size), and development (tables 7-1 and 7-2). Invasive woody species and climate change were evaluated for all grasslands types (see chapter 4, "Grasslands"). Fire occurrence and potentially altered vegetation (including invasive herbaceous plants) were evaluated for the entire SGP (see chapter 3, "Change Agents"). Overall landscape-level ranking variables are summarized in table $7-3$. The core and integrated management questions are listed in table 7-4. 
Table 7-1. Key ecological attributes and associated indicators used to address core management questions for sand prairie for the Southern Great Plains Rapid Ecoregional Assessment.

\begin{tabular}{lll}
\hline \multicolumn{1}{c}{ Attributes } & Variables & \multicolumn{1}{c}{ Indicators $^{1}$} \\
\hline Amount and distribution & Total area & Estimated historical and baseline distributions ${ }^{2}$ of sand prairie \\
Landscape structure & Patch size & Patch sizes for estimated historical and baseline distributions of sand prairie \\
Landscape dynamics & Fire occurrence & See chapter 3, "Change Agents" \\
\hline
\end{tabular}

${ }^{1}$ See chapter 2, "Methods Overview," and appendix A for methods and datasets used.

${ }^{2}$ Baseline distribution is determined by the most current regional data available.

Table 7-2. Anthropogenic change agents and associated indicators used to address core management questions for sand prairie for the Southern Great Plains Rapid Ecoregional Assessment.

[km, kilometer; mi, mile]

\begin{tabular}{|c|c|c|}
\hline \multirow{2}{*}{$\begin{array}{l}\text { Change agents } \\
\text { Development }\end{array}$} & Variables & Indicators $^{1}$ \\
\hline & Index of fragmentation & Patch sizes for relatively undeveloped ${ }^{2}$ sand prairie \\
\hline Climate change & Potential distribution of grasslands & See chapter 4, "Grasslands" \\
\hline
\end{tabular}

${ }^{1}$ See chapter 2, "Methods Overview," and appendix A for methods and datasets used.

${ }^{2}$ Terrestrial development index score less than or equal to 2 percent.

Table 7-3. Landscape-level variables used to address the integrated management question for sand prairie. Ranks for landscapelevel area and development were combined into an overall landscape-level rank for the Southern Great Plains Rapid Ecoregional Assessment.

[>, greater than; km, kilometer; mi, mile]

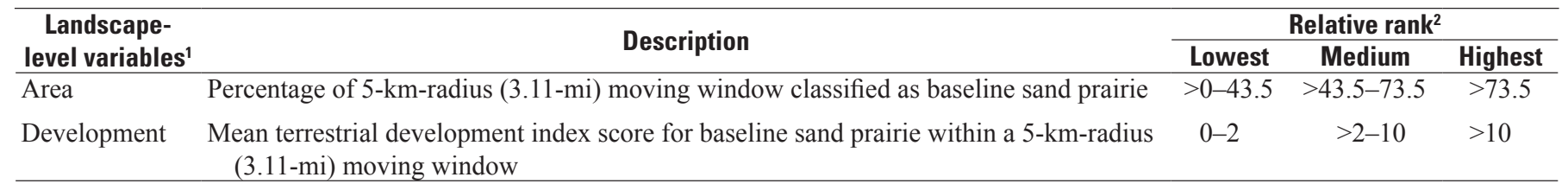

${ }^{1}$ See chapter 2, "Methods Overview," and appendix A for methods and datasets used.

${ }^{2}$ Ranking breakpoints for area of sand prairie were determined from equal subsets of the data. Ranking breakpoints for terrestrial development index scores were standardized for all terrestrial conservation elements.

Table 7-4. Management questions addressed for sand prairie for the Southern Great Plains Rapid Ecoregional Assessment.

\begin{tabular}{|c|c|}
\hline Core management questions ${ }^{1}$ & Results \\
\hline What is the baseline distribution of sand prairie, and where has it been converted by development? & Figure $7-1$ \\
\hline What are the baseline distributions of sand sagebrush and shinnery oak in the sand prairie community? & Figure $7-2$ \\
\hline How has development fragmented sand prairie? & Figures $7-5$ and $7-6$ \\
\hline Integrated management question ${ }^{2}$ & Results \\
\hline Where are the sand prairies with the highest overall landscape-level rank? & Figure 7-7 \\
\hline
\end{tabular}

${ }^{1}$ See chapter 11, "Data Gaps, Limitations, and Uncertainty," for management questions that could not be addressed.

${ }^{2}$ See table $7-3$. 


\section{Management Questions and Results}

What is the baseline distribution of sand prairie, and where has it been converted by development (fig. 7-1)?

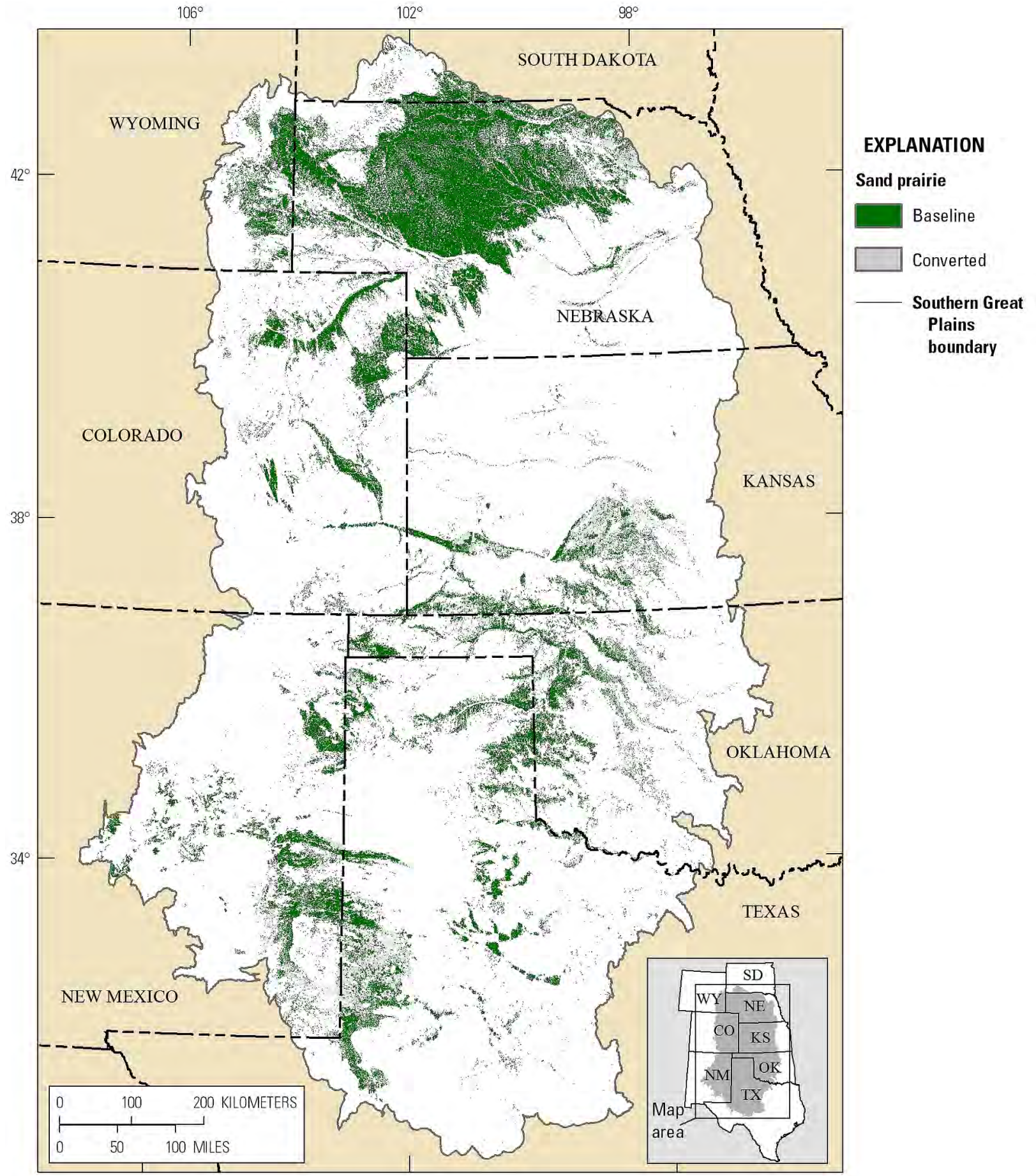

Figure 7-1. Baseline and converted historical distributions of sand prairie in the Southern Great Plains. 
What are the baseline distributions of sand sagebrush and shinnery oak in the sand prairie community (fig. 7-2)?

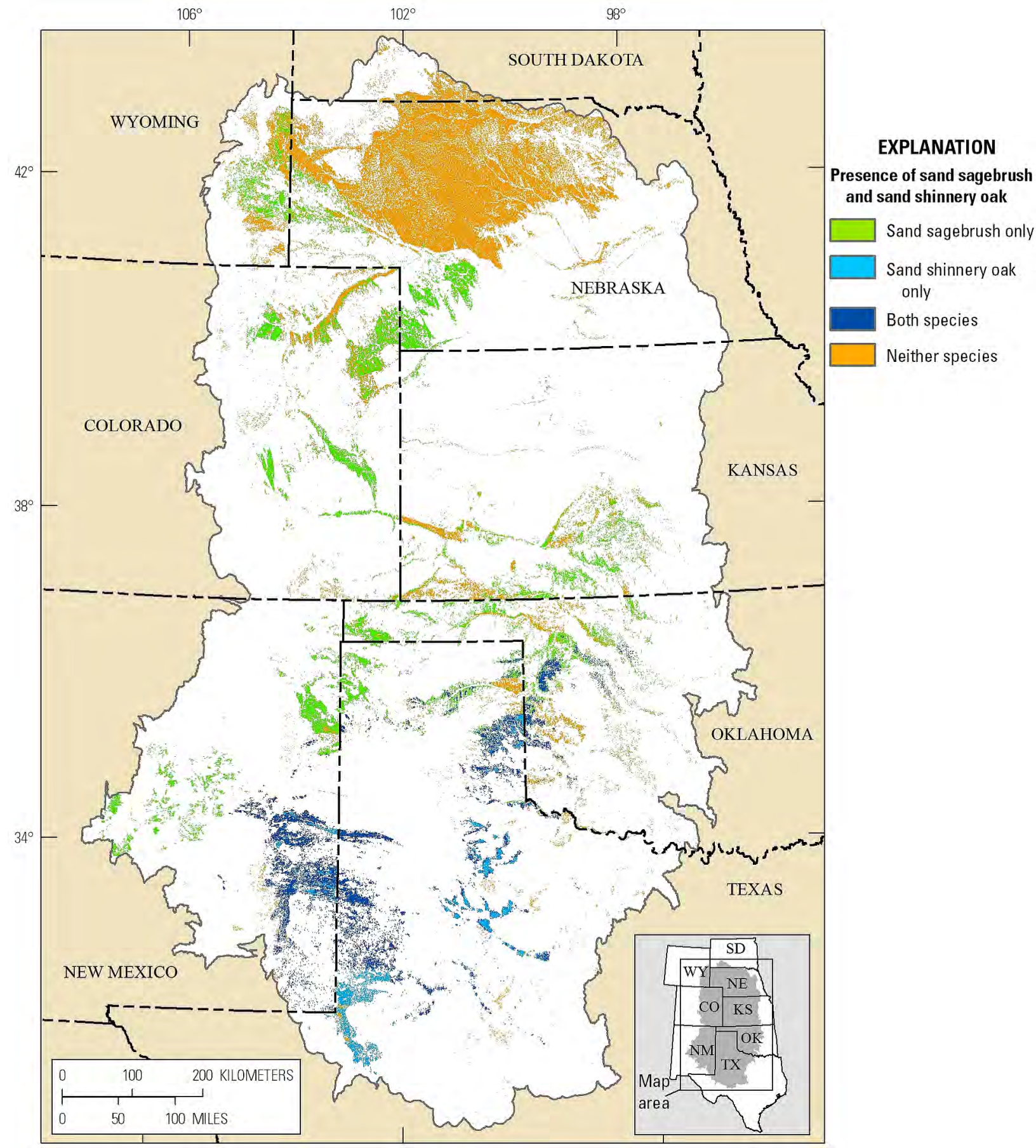

Figure 7-2. Baseline distributions of sand sagebrush and shinnery oak within the sand prairie community in the Southern Great Plains. 
Where does existing development pose the greatest threat to sand prairie, and where are the large, relatively undeveloped areas (figs. 7-3 and 7-4)?

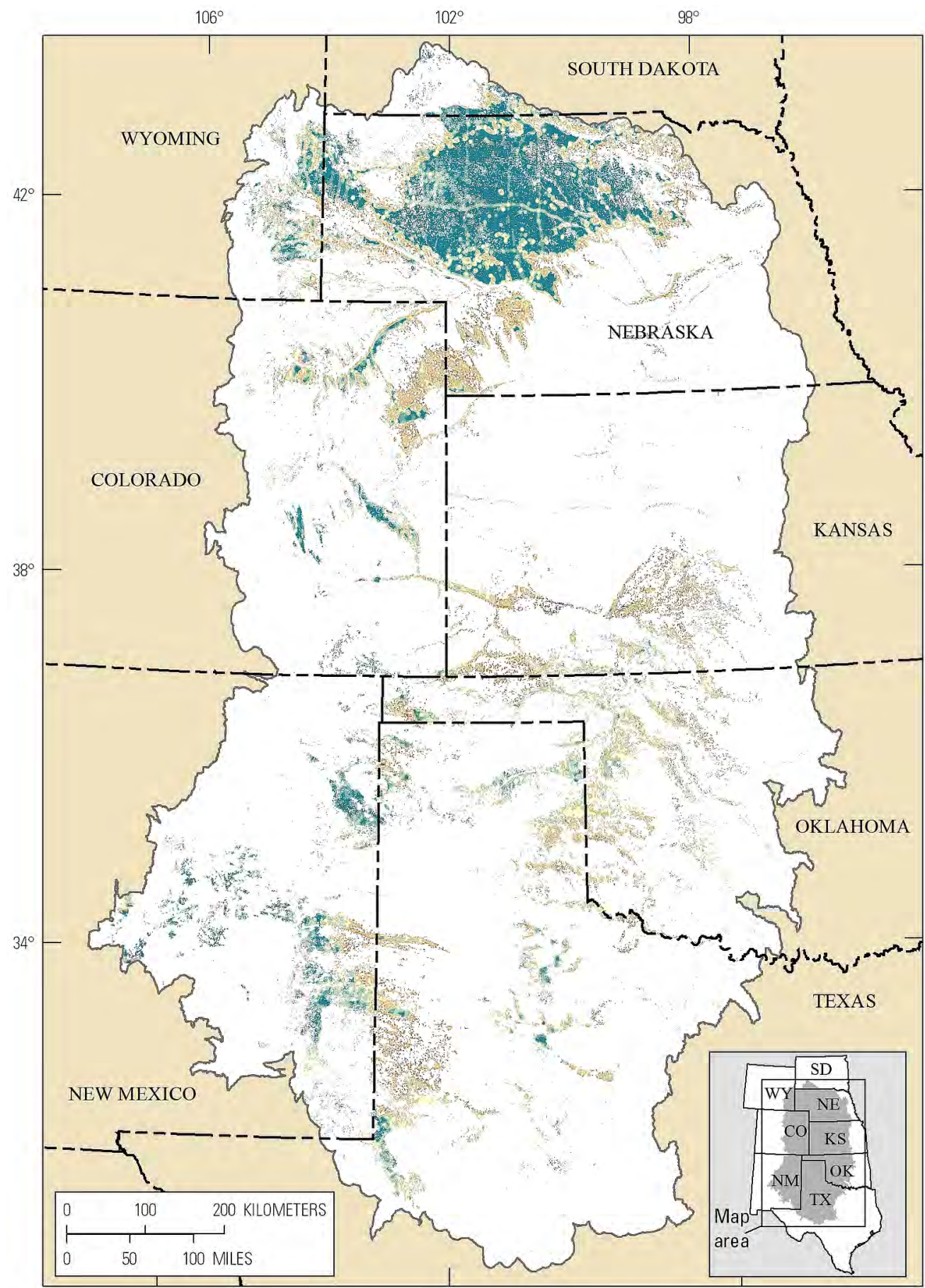

\section{EXPLANATION}

Terrestrial development index, in percent

0 to 1

$>1$ to 2

$>2$ to 5

$>5$ to 10

$>10$ to 35

$>35$ to 65

$>65$ to 100

Figure 7-3. Terrestrial development index for baseline sand prairie in the Southern Great Plains. 


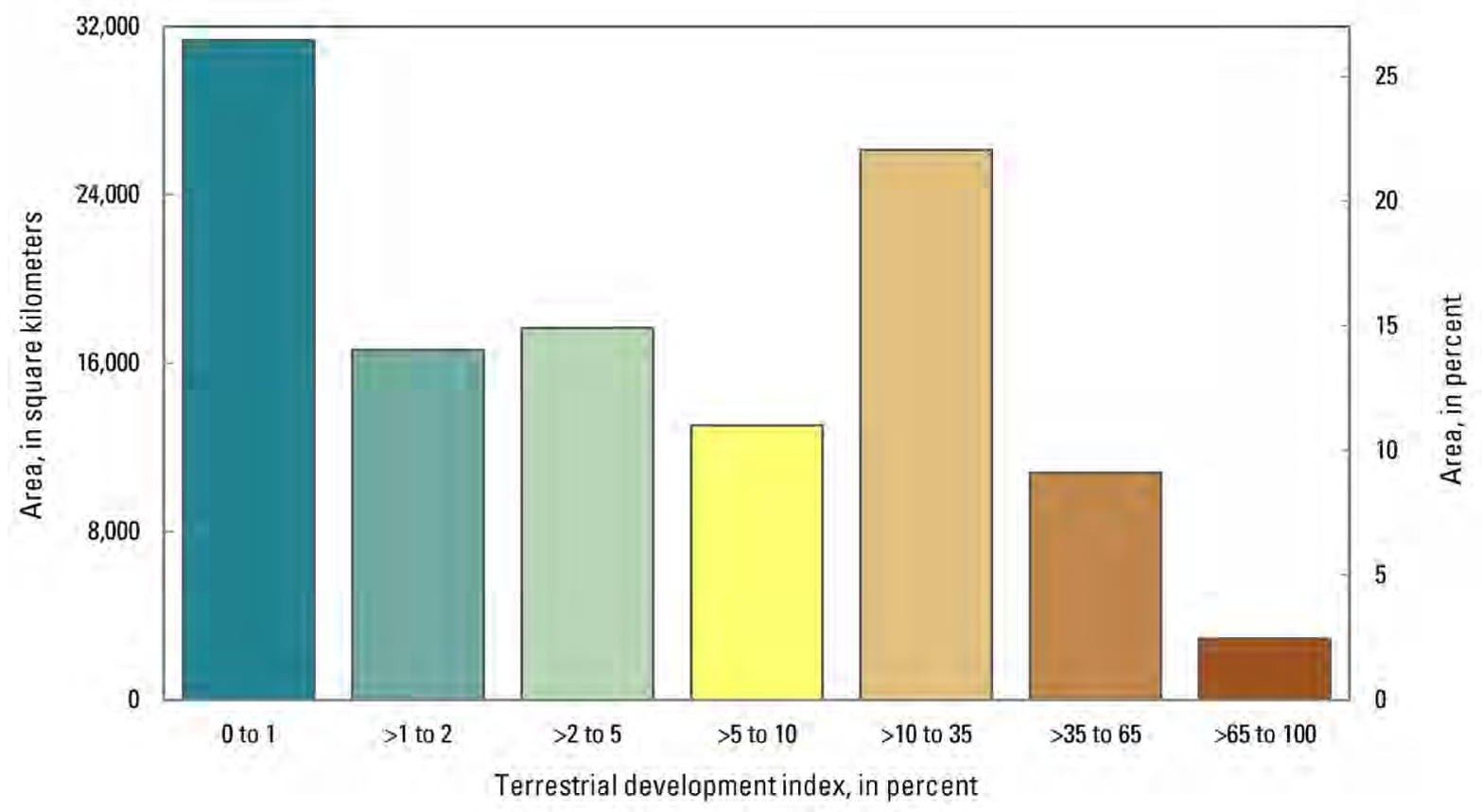

Figure 7-4. Area of baseline sand prairie by terrestrial development index class in the Southern Great Plains.

How has development fragmented sand prairie (figs. 7-5 and 7-6)?

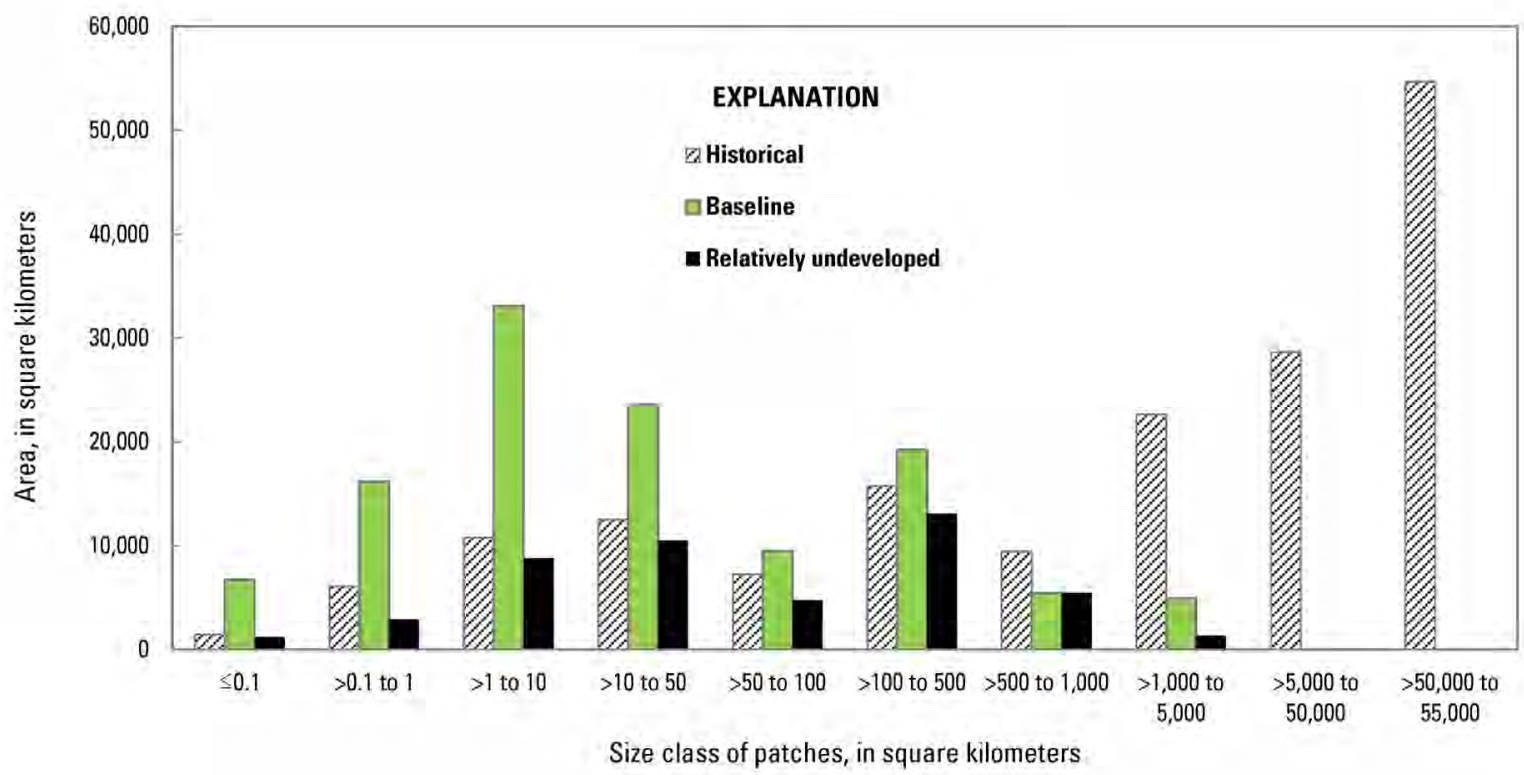

Figure 7-5. Area of sand prairie in the Southern Great Plains as a function of patch size for historical, baseline, and relatively undeveloped conditions (terrestrial development index score $\leq 2$ percent). 

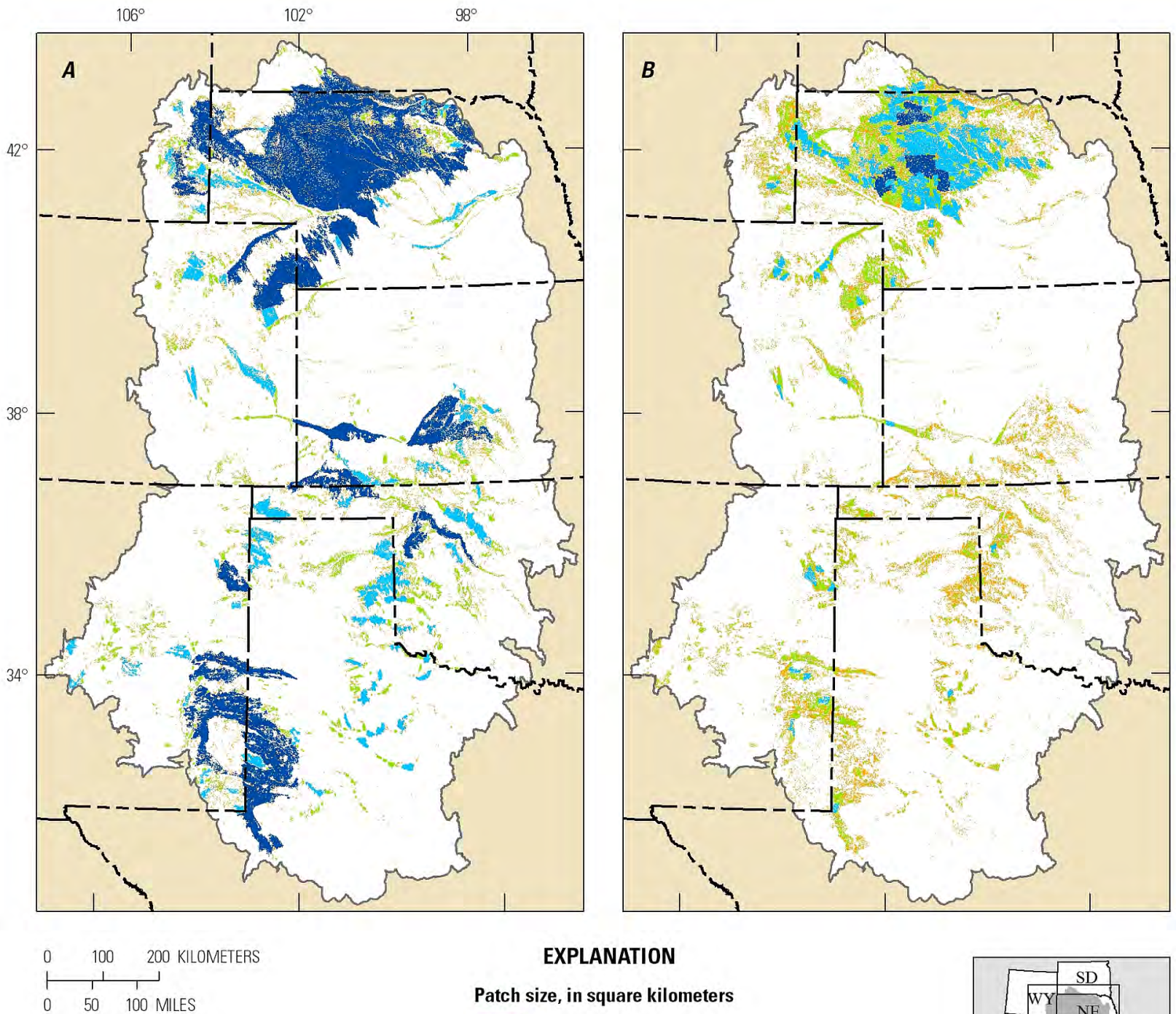

EXPLANATION

Patch size, in square kilometers
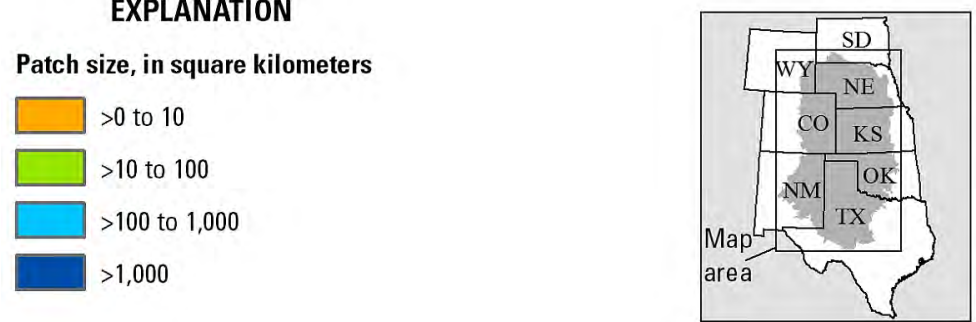

Figure 7-6. Patch size of sand prairie in the Southern Great Plains. A, Estimated historical distribution. B, Baseline distribution. 


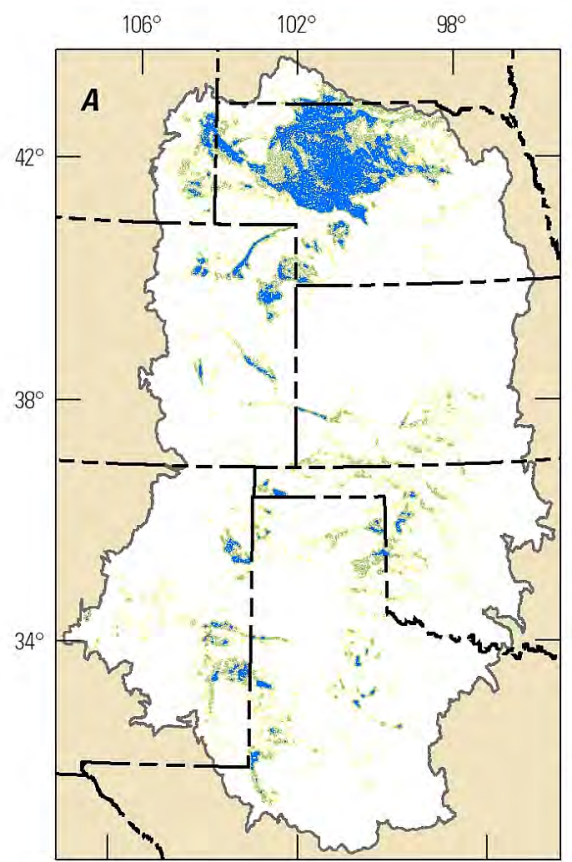

$0 \quad 100200$ KILOMETERS $\longmapsto$

$0 \quad 50100$ MLLES
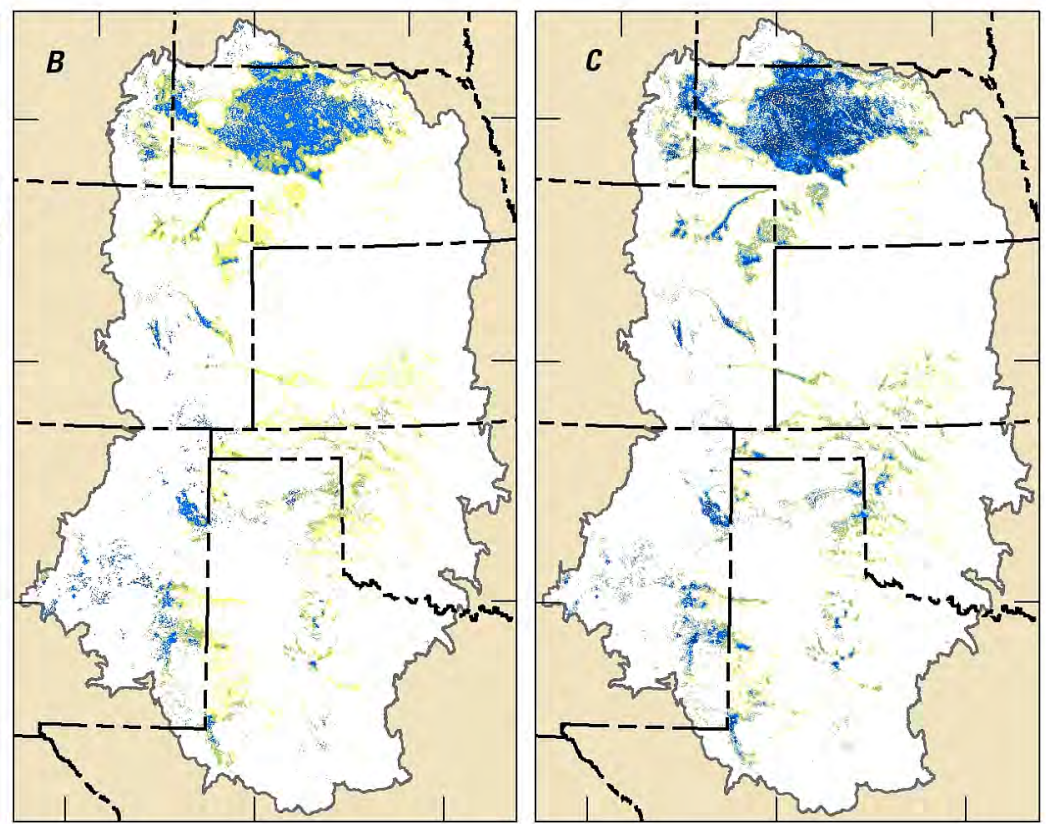

EXPLANATION

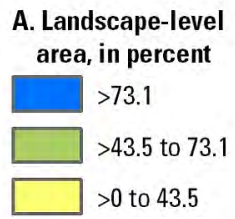

B. Landscape-level development, in percent

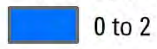

$\square>2$ to 10 $>10$
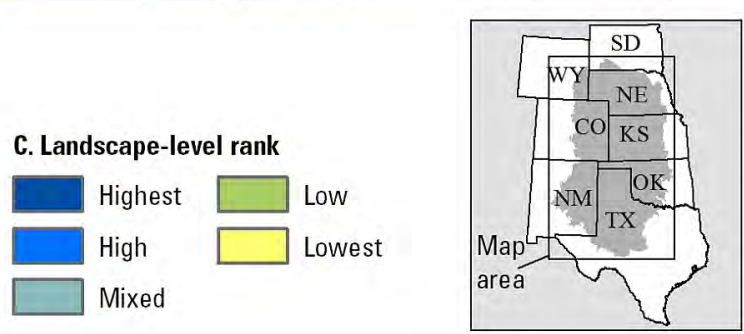

Figure 7-7. Landscape-level summaries for sand prairie in the Southern Great Plains. Overall landscape-level rank $(C)$ is derived from $(A)$ landscape-level area and $(B)$ landscape-level development, summarized by a 5-kilometer-radius (3.11-mile-radius) moving window (see table 7-3). Highest overall landscape-level rank corresponds to the largest landscape-level area and the lowest landscape-level development. Lowest overall landscape-level rank corresponds to the smallest landscape-level area and highest landscape-level development. Landscape-level ranks are not intended as standalone summaries and are best interpreted in conjunction with the geospatial datasets used to address core management questions. 


\section{Summary}

- The current distribution of sand prairie covers less than 13 percent of the SGP, which represents a 30 percent reduction in area from the estimated historical distribution (fig. 7-1). In addition, removal of shinnery oak has altered the structure of sand prairie in many areas (Bragg and Steuter, 1996).

- Currently, over 40 percent of sand prairie is relatively undeveloped (terrestrial development index [TDI] score $\leq 2$ percent), and 15 percent has low development levels (TDI scores 2-5 percent) (figs. 7-3 and 7-4).

- Development has greatly fragmented sand prairie. More than 62 percent of estimated historical sand prairie occurred in patches $>1,000$ square kilometers $\left(\mathrm{km}^{2}\right.$; 386 square miles $\left[\mathrm{mi}^{2}\right]$ ), and large, widely distributed contiguous patches occurred in Nebraska, eastern New Mexico, and western Texas. Only 4 percent of remaining patches exceed $1,000 \mathrm{~km}^{2}\left(386 \mathrm{mi}^{2}\right)$, and more than 75 percent is in patches $<100 \mathrm{~km}^{2}\left(39 \mathrm{mi}^{2}\right)$ (figs. 7-5 and 7-6).

- The areas of sand prairie with the highest overall landscape-level ranks (where landscape-level area is largest and landscape-level development is lowest) are in the Nebraska Sand Hills (fig. 7-7). The patches of sand sagebrush and shinnery oak south of the sand hills are relatively small, but there are many scattered areas that have high overall landscape-level ranks.

\section{References Cited}

Assal, T.J., Melcher, C.P., and Carr, N.B., eds., 2015, Southern Great Plains Rapid Ecoregional AssessmentPre-assessment report: U.S. Geological Survey Open-File Report 2015-1003, 284 p., accessed September 2015 at https://doi.org/10.3133/ofr20151003.
Bragg, T.B., and Steuter, A.A., 1996, Prairie ecology-The mixed prairie, in Samson, F.B., and Knopf, F.L., eds., Prairie conservation-Preserving North America's most endangered ecosystem: Washington, D.C., Island Press, p. 53-66.

Colorado Natural Heritage Program, 2013, Western Great Plains sandhill shrubland, in Ecological systems of Colorado: Colorado Natural Heritage Program website, accessed October 16, 2015, at http:/www.cnhp.colostate.edu/ download/projects/eco_systems/eco_systems.asp.

Peterson, R.S., and Boyd, C.S., 1998, Ecology and management of sand shinnery communities - A literature review: U.S. Department of Agriculture, Forest Service, Rocky Mountain Research Station, General Technical Report RMRS-GTR-16, 44 p.

Stubbendieck, James, Flessner, T.R., and Weedon, Ronald, 1989, Blowouts in the Nebraska Sandhills - The habitat of Penstemon haydenii, in Bragg, T.B., and Stubbendieck, James, eds., Prairie pioneers-Ecology, history and culture. Proceedings of the eleventh North American Prairie Conference, Lincoln, Nebr., August 7-11, 1988: Lincoln, Nebr., University of Nebraska Printing, accessed October 16, 2015, at http://digitalcommons.unl.edu/napcproceedings/3/.

Weaver, J.E., and Albertson, F.W., 1956, Grasslands of the Great Plains - Their nature and use: Lincoln, Nebr., Johnsen Publishing Company, 395 p.

Whitman, W.C., and Barker, W.T., 1994, Rangeland cover types of the northern Great Plains, in Shiflet, T.N., ed., Rangeland cover types of the United States: Denver, Colo., Society for Range Management, p. 69-84.

Winter, S.L., Fuhlendorf, S.D., Goad, C.L., Davis, C.A., Hickman, K.R., and Leslie, D.M., Jr., 2012, Restoration of the fire-grazing interaction in Artemisia filifolia shrubland: Journal of Applied Ecology, v. 49, no. 1, p. 242-250. 



\section{Chapter 8. Riparian and Nonplaya Wetlands}

\section{Introduction}

Riparian and nonplaya wetlands (hereafter referred to as wetlands) are transition zones between aquatic and terrestrial ecosystems and are shaped by processes that affect both ecosystems (Culver, 2014). Riparian areas are strongly influenced by fluvial dynamics including periodic flooding and desiccation. Floods can scour vegetation and alter channel morphology (Naiman and Decamps, 1997). In the Southern Great Plains (SGP), wetlands occur where the water table is at or near the land surface and may be inundated permanently or intermittently. There are both recharge and discharge wetlands, including playa wetlands (addressed in chapter 9, "Playa Wetlands and Saline Lakes"), shallow ponds, marshes, and wet meadows (Haukos and Smith, 2003; Culver, 2014; see table A-5 in appendix A). Woody riparian species include cottonwood (Populus spp.) and willow (Salix spp.). Wetlands may be dominated by herbaceous wetland obligates or facultative species, depending on the timing and duration of inundation. Many riparian plants are adapted to rapidly resprout or recolonize recently disturbed areas (Naiman and Decamps, 1997). Riparian and wetland communities may also be influenced by disturbance from fire, wind, and herbivory (Gregory and others, 1991; Naiman and Decamps, 1997; Mitsch and Gosselink, 2000). Riparian and wetland communities provide nesting, feeding, or roosting habitats for several species of management concern evaluated for the SGP Rapid Ecoregional Assessment: long-billed curlew, snowy plover, interior least tern, and bats.

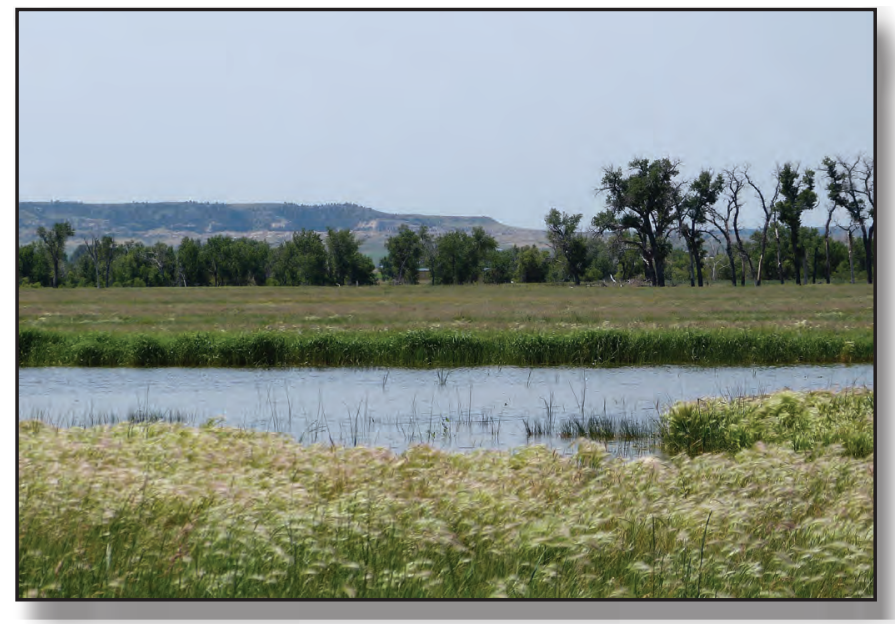

Spotted Tail Wetlands Complex, Nebraska. Photograph by Miruh Hamend, Playa Lakes Joint Venture (used with permission).
Change agents affecting SGP riparian and nonplaya wetlands include agriculture, dams and water diversions, unsuitable grazing practices, and invasive species (Poff and others, 2011). Dams, ditches, road crossings, and energy development can alter flow regimes and sedimentation. Agricultural and infrastructural development can lead to sedimentation, contamination, and groundwater depletion (Smith and others, 2008; Brinson and Eckles, 2011). Redistributions of water can decrease, create, or expand riparian and wetland vegetation (Crifasi, 2005; Wiener and others, 2008). Inundation following reservoir construction kills riparian and wetland vegetation, but it can also promote establishment of riparian and wetland communities on expansive reservoir deltas (Volke and others, 2015) depending on the time since construction. For example, dams can result in channel narrowing that may initially facilitate establishment of cottonwood and willow (Friedman and others, 1998). Over the long-term, however, decreased seasonal flooding can inhibit riparian vegetation regeneration (Friedman and others, 1997). Altered flows and irrigation ditches facilitate invasion by invasive species (Uowolo and others, 2005; Merritt and Poff, 2010). Fire suppression may favor woody plants and promote an increase in fire severity by allowing fuels to accumulate (Dwire and Kauffman, 2003). Finally, climate change could alter hydrological regimes and water temperatures (Bisson and others, 2003; Barnett and others, 2008; Matthews, 2008; Polley and others, 2013). Additional background information can be found in the SGP pre-assessment report (Assal and others, 2015).

\section{Rapid Ecoregional Assessment Components Evaluated for Riparian and Nonplaya Wetlands}

The key ecological attributes and change agents addressed by core management questions for riparian and wetland communities include amount and distribution, landscape structure (patch size), development, and invasive woody species (tables 8-1 and 8-2). Connectivity was addressed for prairie streams and rivers (see chapter 10, "Prairie Streams and Rivers"). Fire occurrence, potentially altered vegetation (including invasive herbaceous plants), and climate change were evaluated for the entire SGP (see chapter 3, "Change Agents"). Overall landscape-level ranking variables are summarized in table $8-3$. The core and integrated management questions are listed in table $8-4$. 
Table 8-1. Key ecological attributes and associated indicators used to address core management questions for riparian and nonplaya wetlands for the Southern Great Plains Rapid Ecoregional Assessment.

\begin{tabular}{|c|c|c|}
\hline Attributes & Variables & Indicators $^{1}$ \\
\hline Amount and distribution & Total area & $\begin{array}{l}\text { Baseline distribution of riparian and nonplaya wetlands }{ }^{2} \text { and area of riparian and nonplaya } \\
\text { wetlands as a percentage of sixth-level watershed }\end{array}$ \\
\hline Landscape structure & Patch size & Patch sizes for baseline riparian and nonplaya wetlands \\
\hline Landscape dynamics & Fire occurrence & See chapter 3, "Change Agents" \\
\hline
\end{tabular}

${ }^{1}$ See chapter 2, "Methods Overview," and appendix A for methods and datasets used.

${ }^{2}$ Baseline distribution is determined by the most current regional data available.

Table 8-2. Anthropogenic change agents and associated indicators used to address core management questions for riparian and nonplaya wetlands for the Southern Great Plains Rapid Ecoregional Assessment.

\begin{tabular}{|c|c|c|}
\hline Change agents & Variables & Indicators $^{1,2}$ \\
\hline \multirow[t]{3}{*}{ Development } & Aquatic development index (ADI) & $\begin{array}{l}\text { Percentage of riparian and nonplaya wetlands in seven } \\
\text { development classes }\end{array}$ \\
\hline & Index of fragmentation & $\begin{array}{l}\text { Patch sizes for relatively undeveloped }{ }^{3} \text { riparian and nonplaya } \\
\text { wetlands }\end{array}$ \\
\hline & $\begin{array}{l}\text { Barriers affecting patch size and structural connectivity } \\
\text { of riparian communities }\end{array}$ & See chapter 10, "Prairie Streams and Rivers" \\
\hline Invasive species & Occurrence and potential for woody species expansion & $\begin{array}{l}\text { Occurrence of Russian olive and tamarisk } \\
\text { Probability of suitable habitat for Russian olive and tamarisk }\end{array}$ \\
\hline
\end{tabular}

Table 8-3. Landscape-level variables used to address the integrated management question for riparian and nonplaya wetlands. Ranks for landscape-level area and development were combined into an overall landscape-level rank for the Southern Great Plains Rapid Ecoregional Assessment.

$[<$, less than; $>$, greater than $]$

\begin{tabular}{|c|c|c|c|c|}
\hline \multirow{2}{*}{$\begin{array}{l}\text { Landscape- } \\
\text { level variables }\end{array}$} & \multirow{2}{*}{ Description } & \multicolumn{3}{|c|}{ Relative rank ${ }^{2}$} \\
\hline & & Lowest & Medium & Highest \\
\hline Development & $\begin{array}{l}\text { Mean aquatic development index score for baseline riparian and nonplaya wetlands, } \\
\text { summarized by fifth-level watershed }\end{array}$ & $0-20$ & $>20-40$ & $>40$ \\
\hline
\end{tabular}

${ }^{1}$ See chapter 2, "Methods Overview," and appendix A for methods and datasets used.

${ }^{2}$ Ranking breakpoints for area of riparian and nonplaya wetlands determined from equal subsets of the data (with adjustments for highly skewed distributions). Ranking breakpoints for aquatic development index scores were standardized for all aquatic conservation elements.

Table 8-4. Management questions addressed for riparian and nonplaya wetlands for the Southern Great Plains Rapid Ecoregional Assessment.

\begin{tabular}{|c|c|}
\hline Core management questions ${ }^{1}$ & Results \\
\hline What is the baseline distribution of riparian and nonplaya wetlands? & Figures $8-1$ and $8-2$ \\
\hline $\begin{array}{l}\text { Where does existing development pose the greatest threat to riparian and nonplaya wetlands, and where are the large, } \\
\text { relatively undeveloped areas? }\end{array}$ & Figures $8-3$ and $8^{-4}$ \\
\hline How has development fragmented riparian and nonplaya wetlands? & Figure $8-5$ \\
\hline Where are Russian olive and tamarisk present, and where are riparian suitable for their expansion? & Figures $8-6$ and $8-7$ \\
\hline Integrated management question ${ }^{2}$ & Results \\
\hline
\end{tabular}

${ }^{1}$ See chapter 11, "Data Gaps, Limitations, and Uncertainty," for management questions that could not be addressed.

${ }^{2}$ See table 8-3. 


\section{Management Questions and Results}

What is the baseline distribution of riparian and nonplaya wetlands (figs. 8-1 and 8-2)?

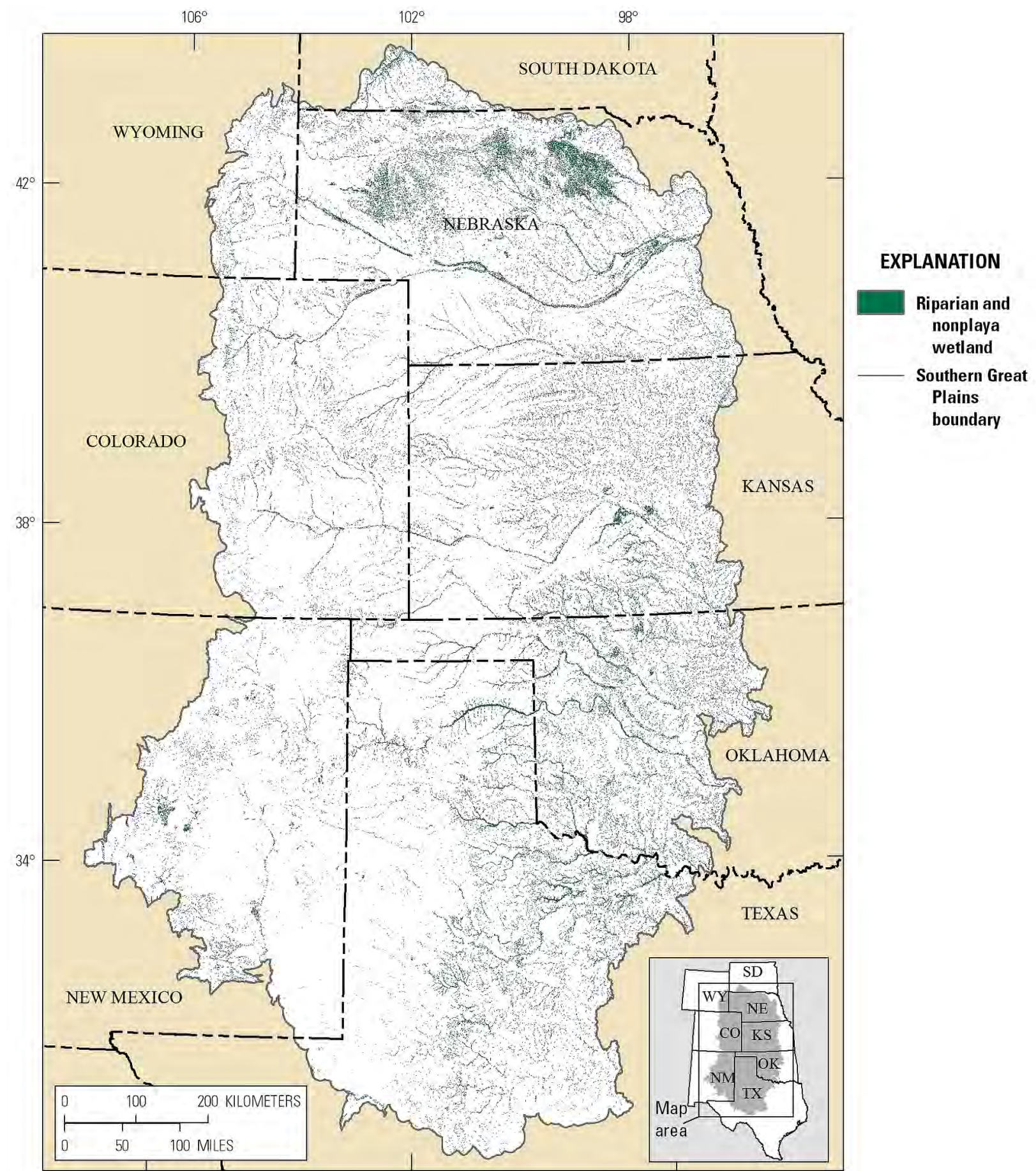

Figure 8-1. Baseline distribution of riparian and nonplaya wetlands in the Southern Great Plains. 


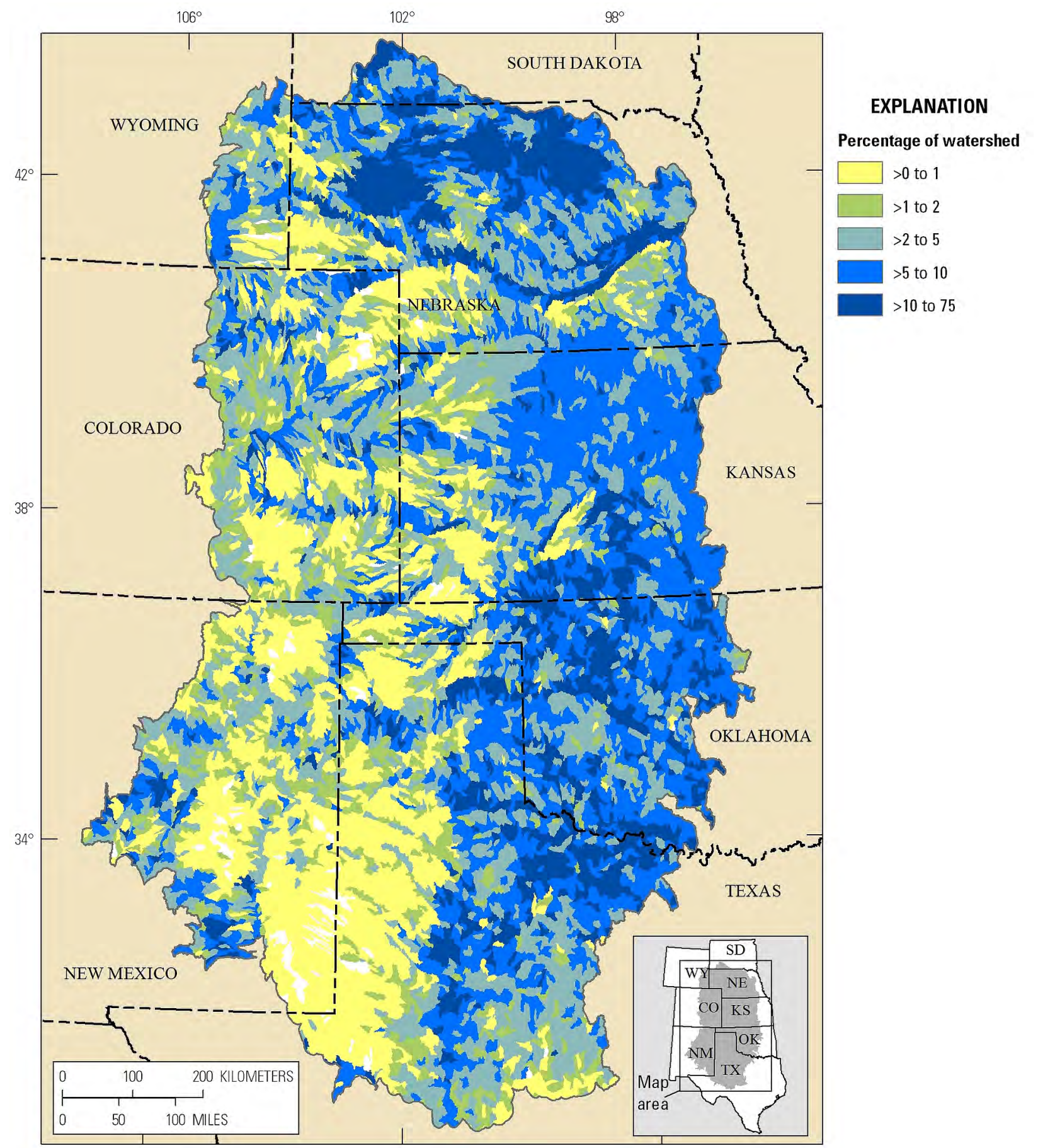

Figure 8-2. Percentage of each sixth-level watershed classified as riparian and nonplaya wetlands in the Southern Great Plains. 
Where does existing development pose the greatest threat to riparian and nonplaya wetlands, and where are the large, relatively undeveloped areas (figs. 8-3 and 8-4)?

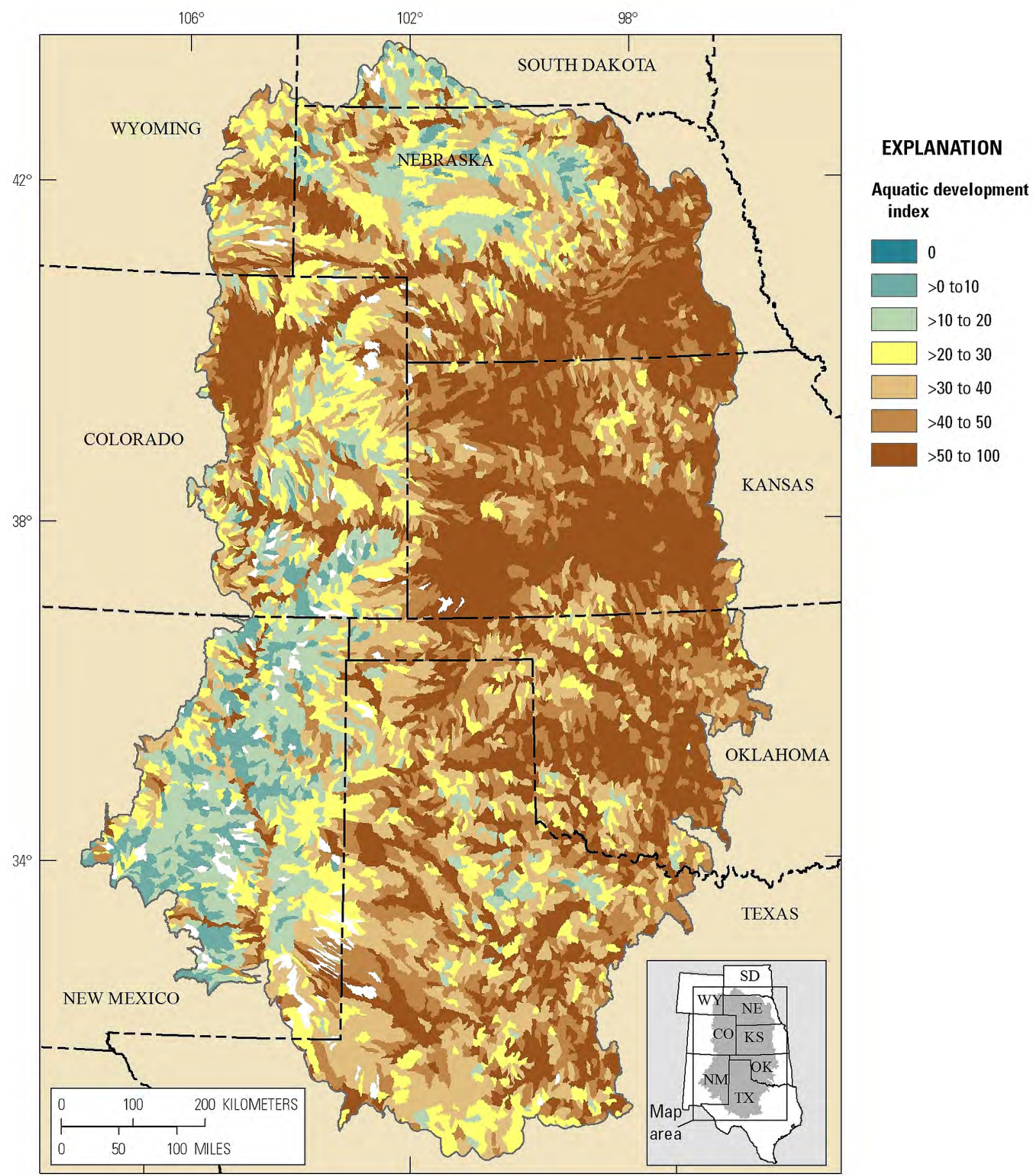

Figure 8-3. Aquatic development index for baseline riparian and nonplaya wetlands, summarized by sixth-level watershed, in the Southern Great Plains. 


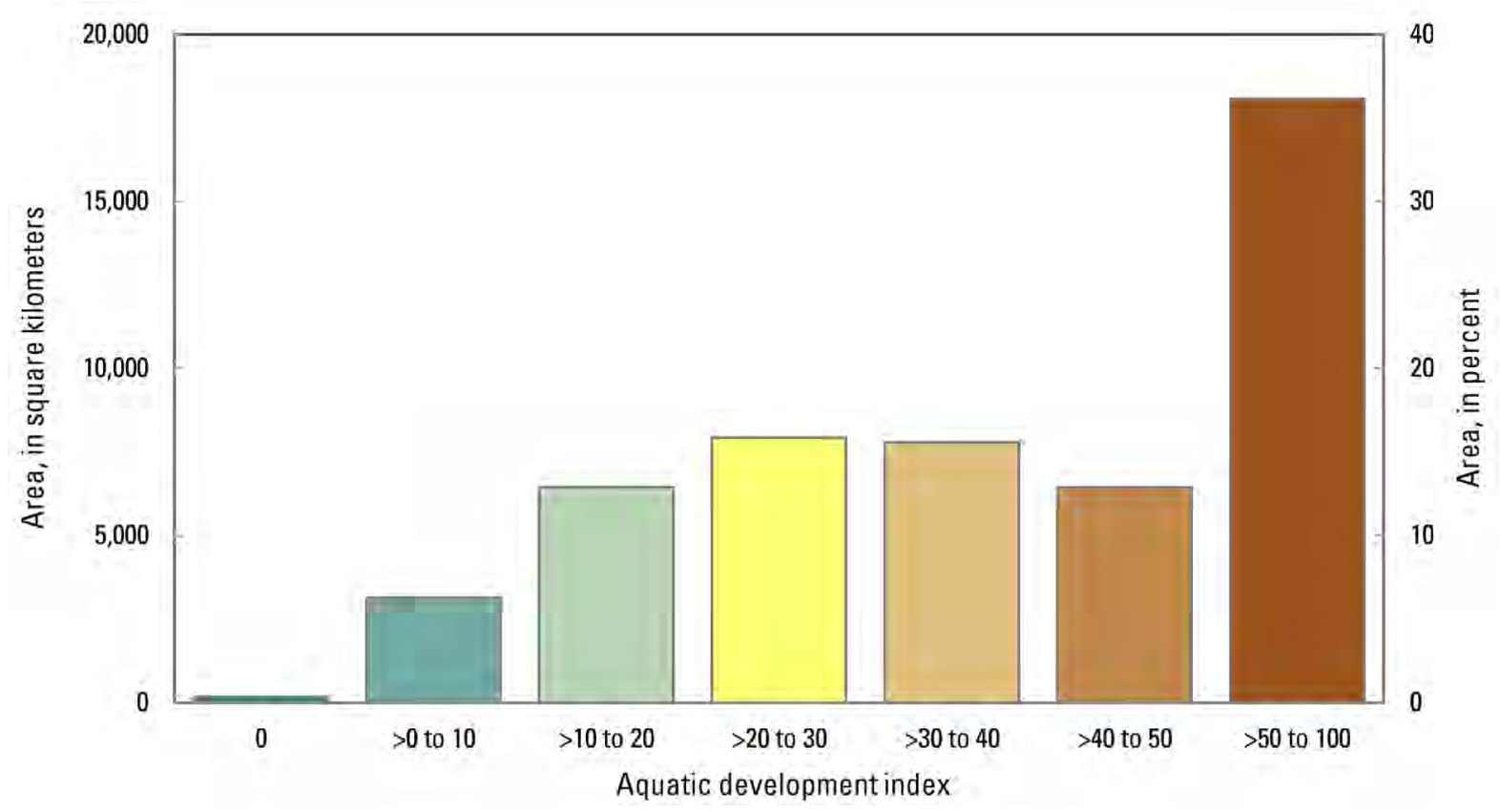

Figure 8-4. Area of baseline riparian and nonplaya wetlands by aquatic development index class in the Southern Great Plains.

How has development fragmented riparian and nonplaya wetlands (fig. 8-5)?

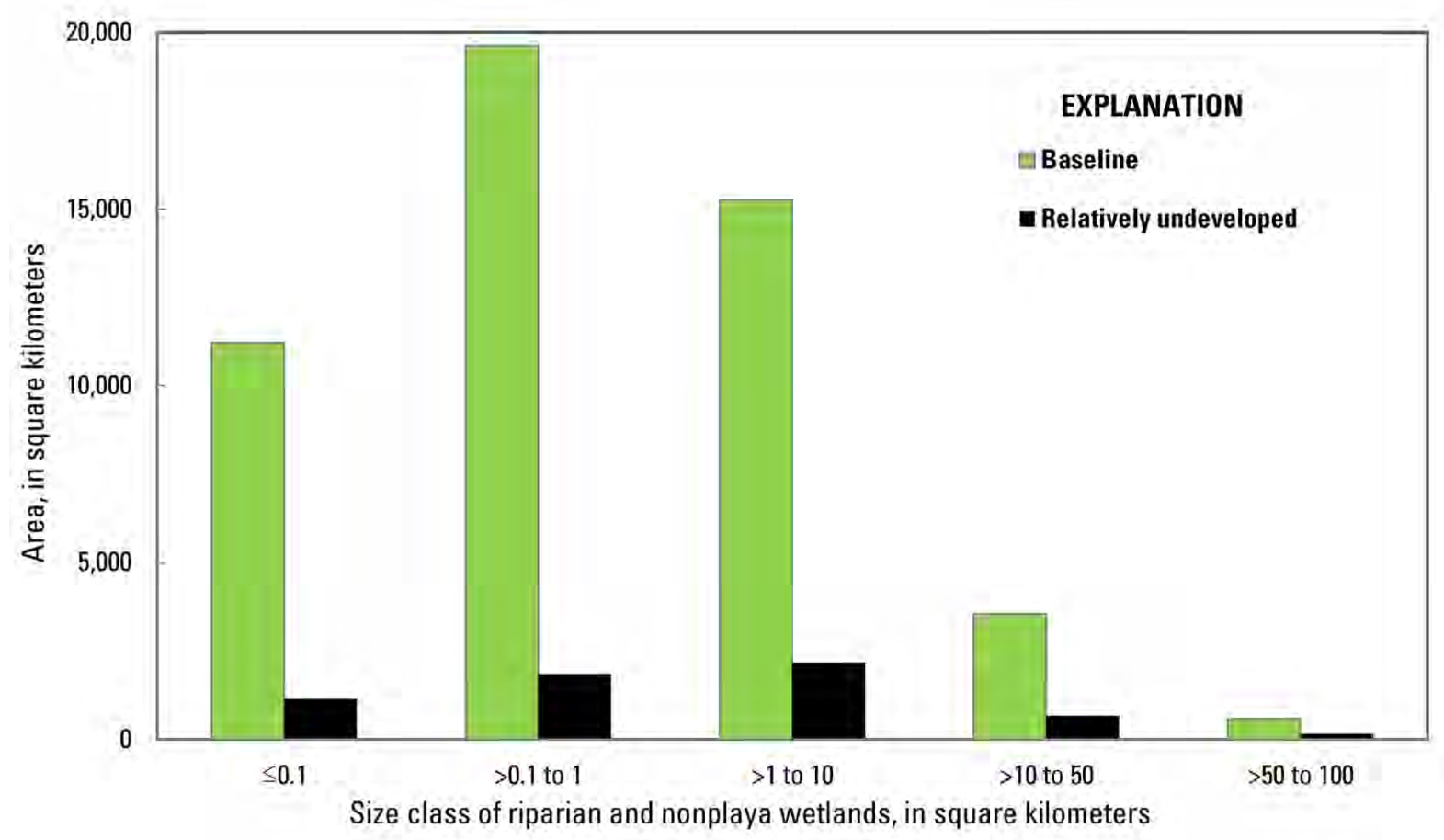

Figure 8-5. Area of riparian and nonplaya wetlands in the Southern Great Plains as a function of patch size for baseline and relatively undeveloped conditions (aquatic development index score $\leq 20$ ). 
Where are Russian olive and tamarisk present, and where are riparian areas suitable for their expansion? (figs. 8-6 and 8-7)?

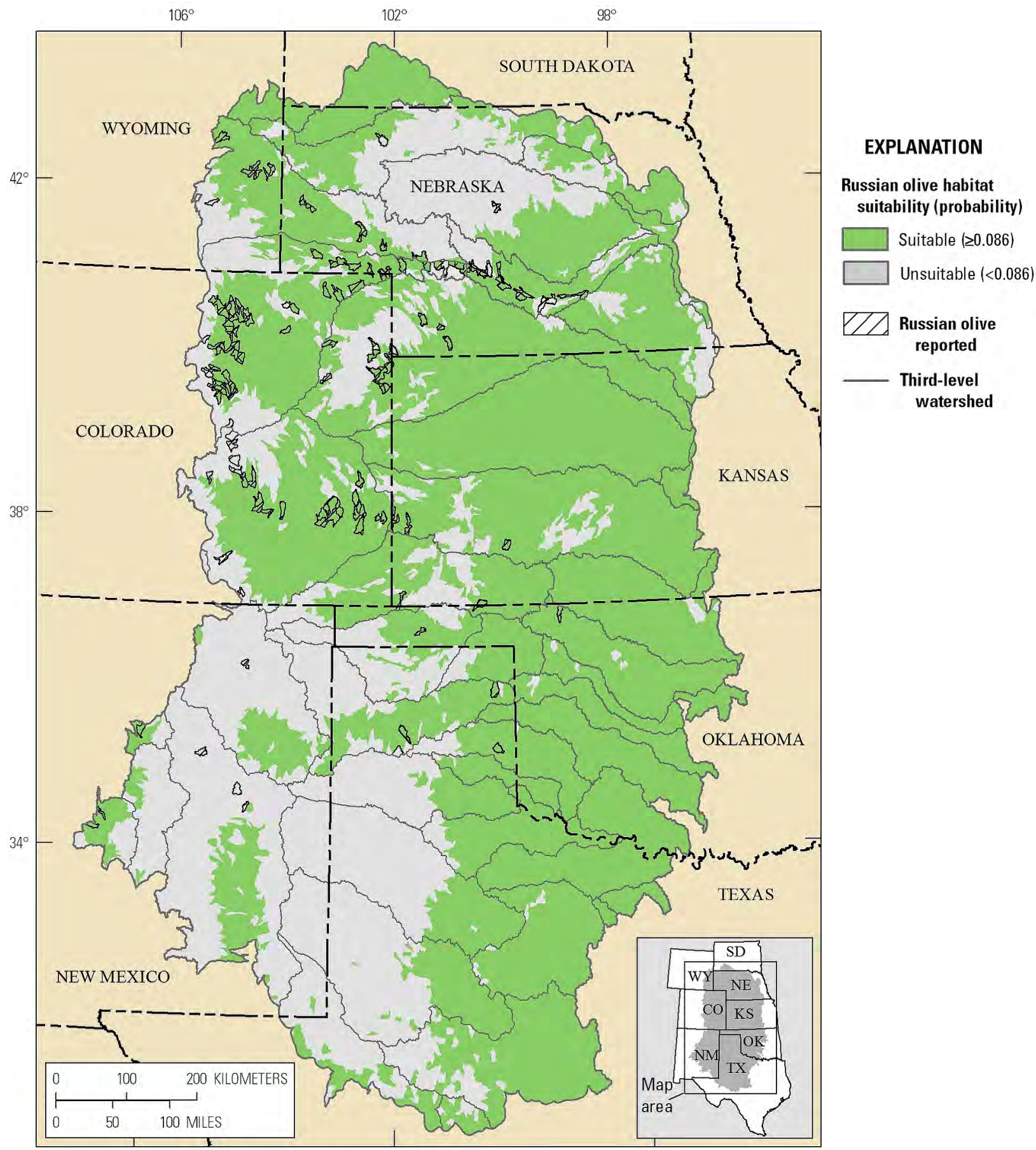

Figure 8-6. Probability of suitable habitat and reported occurrences for Russian olive, summarized by sixth-level watershed, in the Southern Great Plains. Suitable habitat is generally limited to riparian areas within each watershed. 


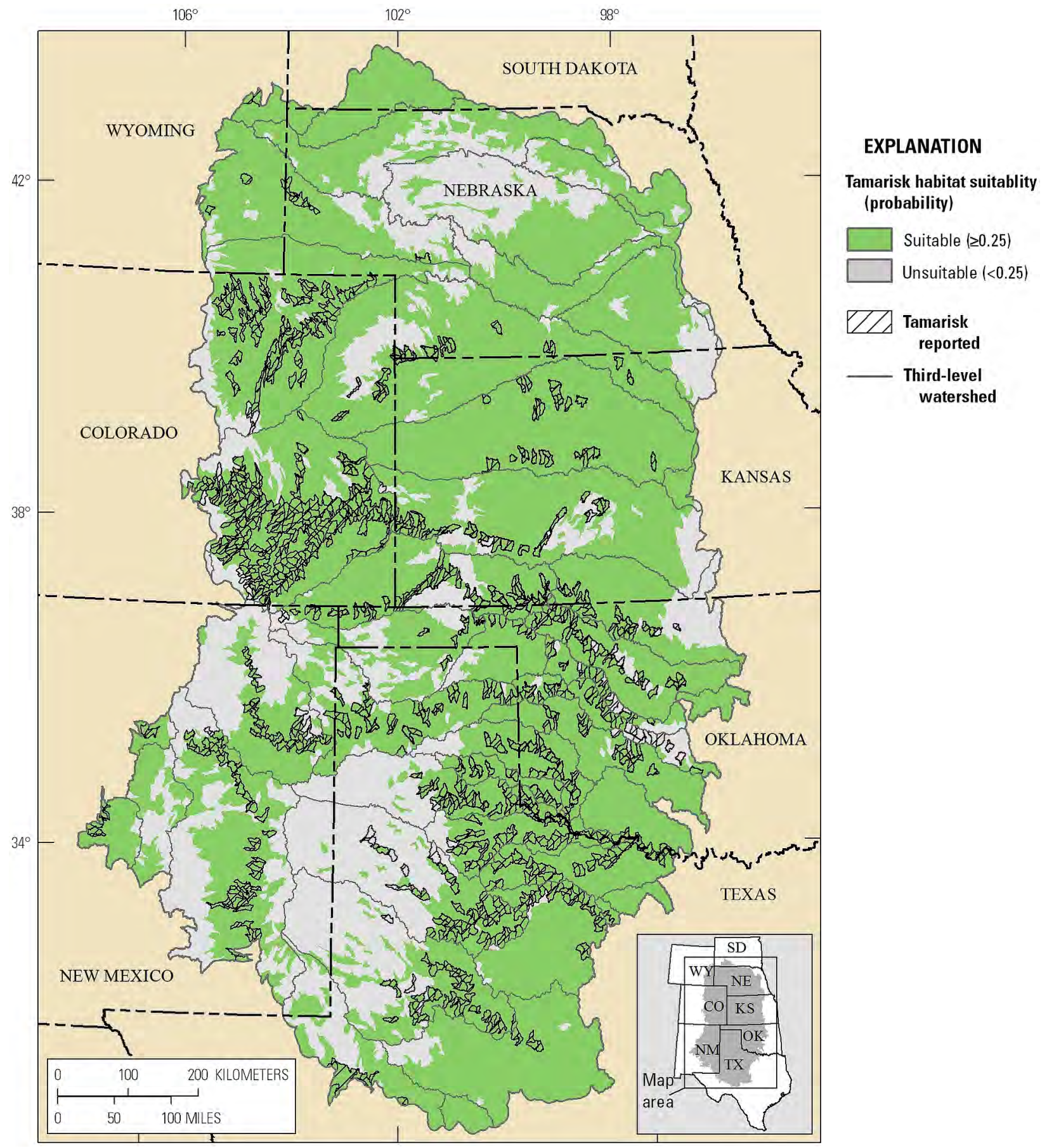

Figure 8-7. Probability of suitable habitat and reported occurrences for tamarisk, summarized by sixth-level watershed, in the Southern Great Plains. Suitable habitat is generally limited to riparian areas within each watershed. 


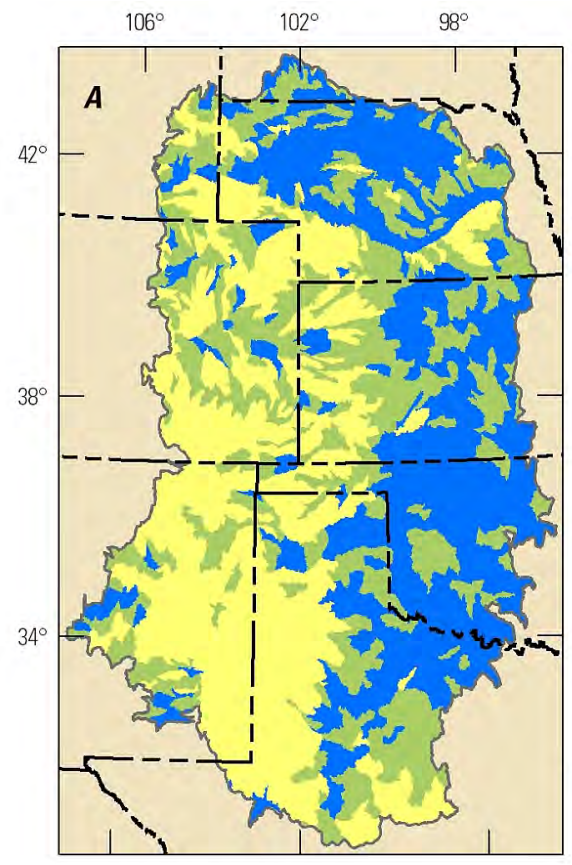

$0 \quad 100200$ KILOMETERS $\longmapsto 1,1$

$0 \quad 50100$ MILES

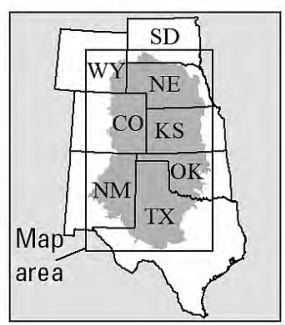
in percent

$\geq 6.15$

2.95 to $<6.15$

$>0$ to $<2.95$

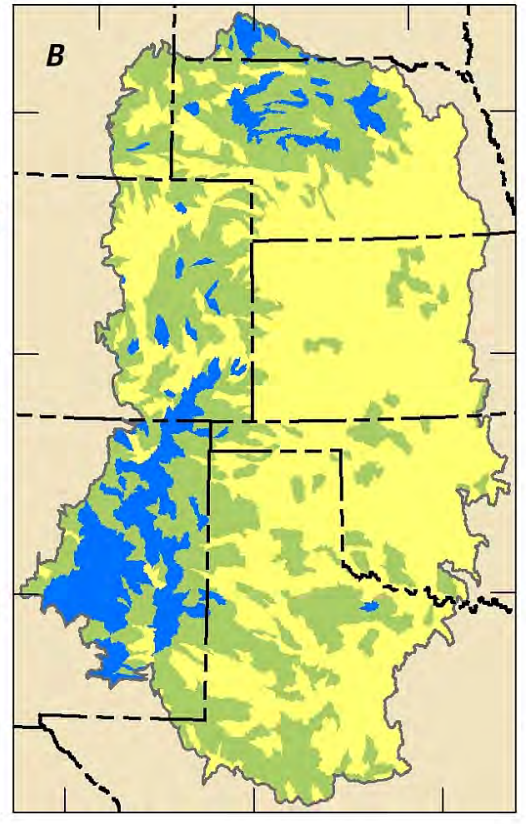

EXPLANATION

A. Landscape-level area,
B. Landscape-level development

0 to 20

$>20$ to 40

$>40$

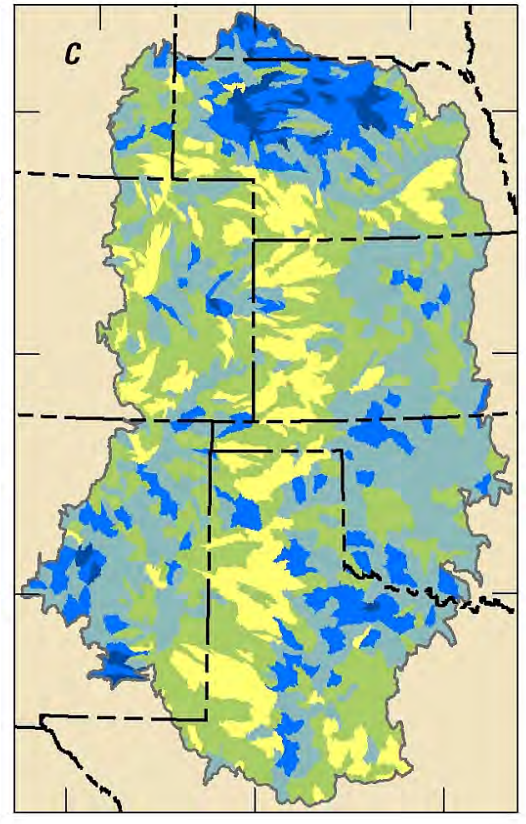

C. Landscape-level rank

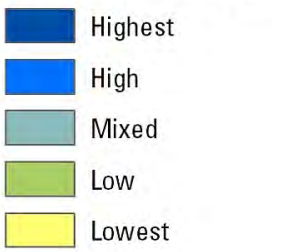

Figure 8-8. Landscape-level summaries for riparian and nonplaya wetlands in the Southern Great Plains. Overall landscape-level rank $(C)$ is derived from $(A)$ landscape-level area, and $(B)$ landscape-level development, summarized by fifth-level watershed (see table 8-3). Highest overall landscape-level rank corresponds to the largest landscape-level area and the lowest landscape-level development. Lowest overall landscape-level rank corresponds to the smallest landscapelevel area and highest landscape-level development. Landscape-level ranks are not intended as standalone summaries and are best interpreted in conjunction with the geospatial datasets used to address core management questions. 


\section{Summary}

- The surface area of riparian and nonplaya wetlands is approximately 50,210 square kilometers $\left(\mathrm{km}^{2}\right.$; 19,390 square miles $\left[\mathrm{mi}^{2}\right]$ ), representing 5.2 percent of the SGP. Watersheds with the greatest riparian and wetland area occur in the northern and eastern portions of the SGP, especially in the Nebraska Sand Hills, where there is a greater density of perennial streams compared to the western and southwestern portions of the SGP, where intermittent streams are more common (figs. 8-2, 10-2, and 10-3).

- About 20 percent of riparian and wetland areas are relatively undeveloped (aquatic development index [ADI] score $\leq 20$ ), and about 49 percent have moderate to high development (ADI score $>40$ ), primarily in the eastern portions of the SGP (figs. 8-3 and 8-4).

- Riparian and wetland areas are naturally small, and the distribution of patch sizes is similar among all development levels, but relatively undeveloped areas make up a fraction of the total baseline distribution (fig. 8-5). There are complex interactions between natural dynamics and altered hydrological regimes that can both create and destroy these communities (Friedman and others, 1997).

- Russian olive and tamarisk occur in many riparian areas of the SGP (figs. 8-6 and 8-7). Models indicate that conditions suitable for expansion of these nonnative species are widespread in the SGP. Comprehensive surveys are needed to improve habitat suitability models for these invasive plants (see chapter 11, "Data Gaps, Limitations, and Uncertainty").

- Most of the watersheds with the highest overall landscape-level ranks occur in the northeastern, southwestern, and southeastern portions of the SGP (fig. $8-8 C$ ).

\section{References Cited}

Assal, T.J., Melcher, C.P., and Carr, N.B., eds., 2015, Southern Great Plains Rapid Ecoregional AssessmentPre-assessment report: U.S. Geological Survey Open-File Report 2015-1003, 284 p., accessed September 2015 at https://doi.org/10.3133/ofr20151003.

Barnett, T.P., Pierce, D.W., Hidalgo, H.G., Bonfils, Celine, Santer, B.D., Das, Tapash, Bala, Govindasamy, Wood, A.W., Nozawa, Toru, Mirin, A.A., Cayan, D.R., and Dettinger, M.D., 2008, Human-induced changes in the hydrology of the western United States: Science, v. 319, p. 1080-1083.
Bisson, P.A., Rieman, B.E., Luce, Charlie, Hessburg, P.F., Lee, D.C., Kershner, J.L., Reeves, G.H., and Gresswell, R.E., 2003, Fire and aquatic ecosystems of the western USACurrent knowledge and key questions: Forest Ecology and Management, v. 178, p. 213-229.

Brinson, M.M., and Eckles, S.D., 2011, U.S. Department of Agriculture conservation program and practice effects on wetland ecosystem services-A synthesis: Ecological Applications, v. 21, p. S116-S127.

Crifasi, R.R., 2005, Reflections on a stock pond-Are anthropogenically derived freshwater ecosystems natural, artificial, or something else?: Environmental Management, v. 36, p. 625-639.

Culver, D.R., 2014, Common wetland plants of Colorado's eastern plains-A pocket guide: U.S. Environmental Protection Agency, prepared by Colorado Natural Heritage Program, Fort Collins, Colo., 154 p., accessed June 2017 at http://www.cnhp.colostate.edu/cwic/ident/fieldGuideEP.aspx.

Dwire, K.A., and Kauffman, J.B., 2003, Fire and riparian ecosystems in landscapes of the western USA: Forest Ecology and Management, v. 178, p. 61-74.

Friedman, J.M., Osterkamp, W.R., Scott, M.L., and Auble, G.T., 1998, Downstream effects of dams-Regional patterns in the Great Plains: Wetlands, v. 18, p. 619-633.

Friedman, J.M., Scott, M.L., and Auble, G.T., 1997, Water management and cottonwood forest dynamics along prairie streams, in Knopf, F.L., and Samson, F.B., eds., Ecology and conservation of Great Plains vertebrates: New York, Springer, p. 49-71.

Gregory, S.V., Swanson, F.J., McKee, W.A., and Cummins, K.W., 1991, An ecosystem perspective of riparian zones: BioScience, v. 41, p. 540-551.

Haukos, D.A., and Smith, L.M., 2003, Past and future impacts of wetland regulation on playa ecology in the Southern Great Plains: Wetlands, v. 23, p. 577-589.

Matthews, J.H., 2008, Anthropogenic climate change in the Playa Lakes Joint Venture Region-Understanding impacts, discerning trends, and developing responses: Playa Lakes Joint Venture, prepared by World Wildlife Fund, Corvallis, Oreg., 40 p., accessed February 2014 at http://www.pljv.org/ documents/science/PLJV_climate_change_review.pdf.

Merritt, D.M., and Poff, N.L., 2010, Shifting dominance of riparian Populus and Tamarix along gradients of flow alteration in western North American rivers: Ecological Applications, v. 20, p. 135-152.

Mitsch, W.J., and Gosselink, J.G., 2000, Wetlands (3d ed.): New York, John Wiley and Sons, 938 p.

Naiman, R.J., and Decamps, Henri, 1997, The ecology of interfaces-Riparian zones: Annual Review of Ecology and Systematics, v. 28, p. 621-658. 
Poff, Boris, Koestner, K.A., Neary, D.G., and Henderson, Victoria, 2011, Threats to riparian ecosystems in western North America-An analysis of existing literature: Journal of the American Water Resources Association, v. 47, p. 1241-1254.

Polley, H.W., Briske, D.D., Morgan, J.A., Wolter, Klaus, Bailey, D.W., and Brown, J.R., 2013, Climate change and North American rangelands - Trends, projections, and implications: Rangeland Ecology and Management, v. 66, p. 493-511.

Smith, L.M., Euliss, N.H., Jr., Wilcox, D.A., and Brinson, M.M., 2008, Application of a geomorphic and temporal perspective to wetland management in North America: Wetlands, v. 28 , p. $563-577$.
Uowolo, A.L., Binkley, Dan, and Adair, E.C., 2005, Plant diversity in riparian forests in northwest Colorado-Effects of time and river regulation: Forest Ecology and Management, v. 218, p. 107-114.

Volke, M.A., Scott, M.L., Carter Johnson, W., and Dixon, M.D., 2015, The ecological significance of emerging deltas in regulated rivers: Bioscience, v. 65, p. 598-611.

Wiener, J.D., Dwire, K.A., Skagen, S.K., Crifasi, R.R., and Yates, David, 2008, Riparian ecosystem consequences of water redistribution along the Colorado Front Range: Water Resources Impact, v. 10, p. 18-21. 



\section{Chapter 9. Playa Wetlands and Saline Lakes}

\section{Introduction}

In the Southern Great Plains (SGP), playa wetlands (hereafter referred to as playas) and saline lakes are isolated, depressional wetlands (Tiner, 2003). Playas are small, shallow, freshwater recharge wetlands located at the low points of small watersheds in relatively level terrain. They fill during heavy storms, which occur erratically. An estimated 66,000 to 80,000 playas are largely distributed in association with the Ogallala aquifer (Gurdak and Roe, 2009; Playa Lakes Joint Venture, 2014). Playa density and size increase from southwest to northeast along a gradient of increasing average precipitation, although soil texture also influences playa density (Smith, 2003). Saline lakes, which are typically larger and deeper than playas, are discharge wetlands in eroded terrain or the low points of paleolakes. Saline lakes occur primarily in northwestern Texas and northeastern to east-central New Mexico (Hall, 2001; Allen, 2005). Playas and saline lakes provide crucial wildlife habitats, especially for migratory waterbirds (Haukos and Smith, 1994; Andrei and others, 2008). Snowy plover, long-billed curlew, interior least tern, and bats are species assessed by the SGP Rapid Ecoregional Assessment that use playas or saline lakes.

Much is unknown about the processes that historically influenced playa and saline lake communities, but they included fire, herbivory, and drought (Smith, 2003). Although

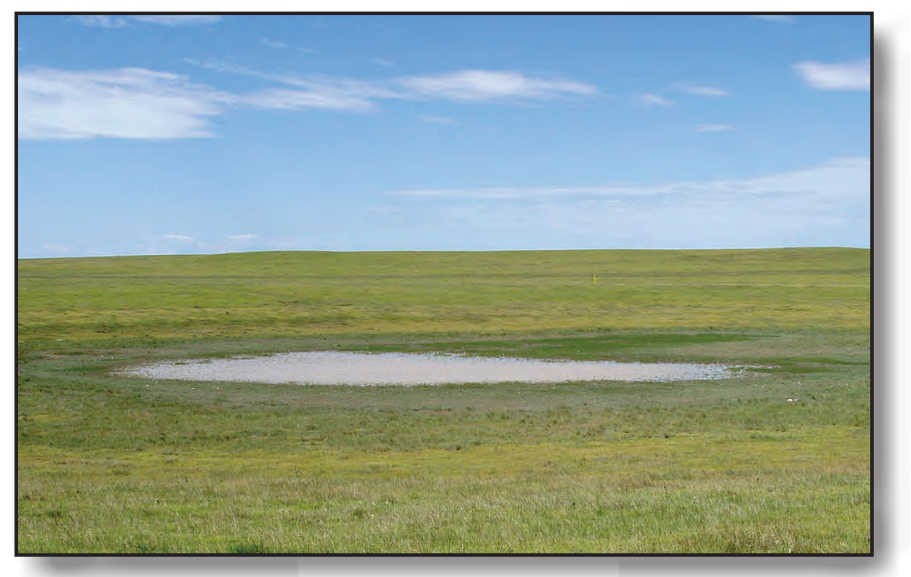

Playa wetland, eastern Colorado. Photograph by Anne Bartuszevige, Playa Lakes Joint Venture (used with permission). characterized by frequent, low-intensity fires, more intense fires may have occurred after pulses of vegetative growth followed by severe drought (Samson and Knopf, 1996; Smith, 2003). Since European settlement, human influences including fire suppression, grazing practices, invasive species, agricultural conversion, and groundwater withdrawal in surrounding watersheds have contributed to habitat fragmentation, altered hydrology, and increased accumulated sediments in basins (Smith, 2003; Burris and Skagen, 2013). Land uses surrounding playas, particularly cultivation of corn and wheat, can reduce inundation frequency, increase sedimentation, and alter hydroperiods compared to playas located in grasslands or pasture (Tsai and others, 2007; Collins and others, 2014). Intensive energy development, urbanization, and livestock may result in nonpoint-source contamination (Irwin and others, 1996). Transmission lines, roads, and wind energy development can fragment wetland complexes and can create collision hazards for bats and birds that may congregate at playas and lakes (Stewart and others, 2005; Horn and others, 2008). Invasive plant species and diseases promoted by altered hydrological regimes and contamination further alter and degrade ecological processes and wildlife habitats (Friend, 1982; Smith, 2003). Additional background information can be found in the SGP pre-assessment report (Assal and others, 2015).

\section{Rapid Ecoregional Assessment Components Evaluated for Playa Wetlands and Saline Lakes}

The key ecological attributes and change agents addressed by core management questions for playas and saline lakes include amount and distribution, landscape structure (patch size), and development (tables 9-1 and 9-2). Fire occurrence, potentially altered vegetation (including invasive herbaceous plants), and climate change were evaluated for the entire SGP (see chapter 3, "Change Agents"). Overall landscape-level variables are summarized in table 9-3. The core and integrated management questions are listed in table $9-4$. 
Table 9-1. Key ecological attributes and associated indicators used to address core management questions for playa wetlands and saline lakes for the Southern Great Plains Rapid Ecoregional Assessment.

\begin{tabular}{|c|c|c|}
\hline Attributes & Variables & Indicators $^{1}$ \\
\hline Amount and distribution & Total area & $\begin{array}{l}\text { Baseline distributions }{ }^{2} \text { of playas and saline lakes; and area of playas as a percentage } \\
\text { of sixth-level watershed areas }\end{array}$ \\
\hline Landscape structure & Patch size & Patch sizes for baseline playas and saline lakes \\
\hline Landscape dynamics & Fire occurrence & See chapter 3, "Change Agents" \\
\hline
\end{tabular}

${ }^{1}$ See chapter 2, "Methods Overview," and appendix A for methods and datasets used.

${ }^{2}$ Baseline distribution is determined by the most current regional data available.

Table 9-2. Anthropogenic change agents and associated indicators used to address core management questions for playa wetlands and saline lakes for the Southern Great Plains Rapid Ecoregional Assessment.

\begin{tabular}{cll}
\hline Change agents & \multicolumn{1}{c}{ Variables } & \multicolumn{1}{c}{ Indicators $^{1}$} \\
\hline Development & Local aquatic development index (ADI) & Percentage of playas and saline lakes in seven development classes ${ }^{2}$ \\
& Index of fragmentation & Patch sizes for relatively undeveloped $^{3}$ playas and saline lakes \\
\hline
\end{tabular}

${ }^{1}$ See chapter 2, "Methods Overview," and appendix A for methods and datasets used.

${ }^{2}$ Summarized by sixth-level watershed.

${ }^{3}$ Relatively undeveloped: local aquatic development index less than or equal to 20 .

Table 9-3. Landscape-level variables used to address the integrated management question for playa wetlands and saline lakes. Ranks for landscape-level area and development were combined into an overall landscape-level rank for the Southern Great Plains Rapid Ecoregional Assessment.

$[<$, less than; $>$, greater than $]$

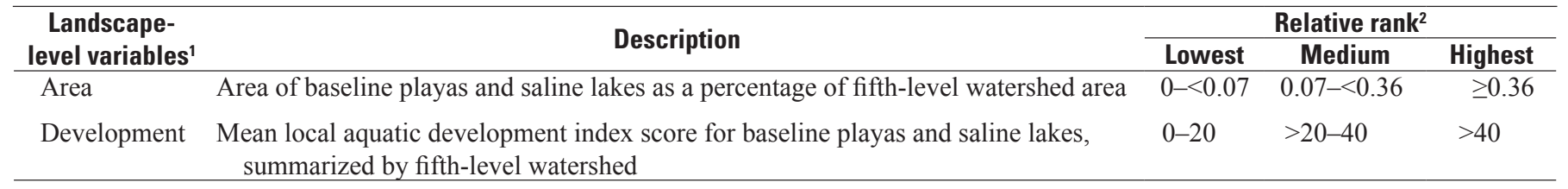

${ }^{1}$ See chapter 2, "Methods Overview," and appendix A for methods and datasets used.

${ }^{2}$ Ranking breakpoints for area of playa wetlands and saline lakes were determined from equal subsets of the data. Ranking breakpoints for the aquatic development index were standardized for all aquatic conservation elements.

Table 9-4. Management questions addressed for playa wetlands and saline lakes for the Southern Great Plains Rapid Ecoregional Assessment.

\begin{tabular}{|c|c|}
\hline Core management questions ${ }^{1}$ & Results \\
\hline $\begin{array}{l}\text { Where does existing development pose the greatest threat to playas and saline lakes, and where are the large, relatively } \\
\text { undeveloped areas? }\end{array}$ & Figures $9-4$ to $9-6$ \\
\hline How has development fragmented playas and saline lakes? & Figures 9-7 \\
\hline Integrated management question ${ }^{2}$ & Results \\
\hline Where are the watersheds with the highest overall landscape-level rank for playas and saline lakes? & Figure 9-8 \\
\hline
\end{tabular}




\section{Management Questions and Results}

What are the baseline distributions of playa wetlands and saline lakes (fig. 9-1 to 9-3)?

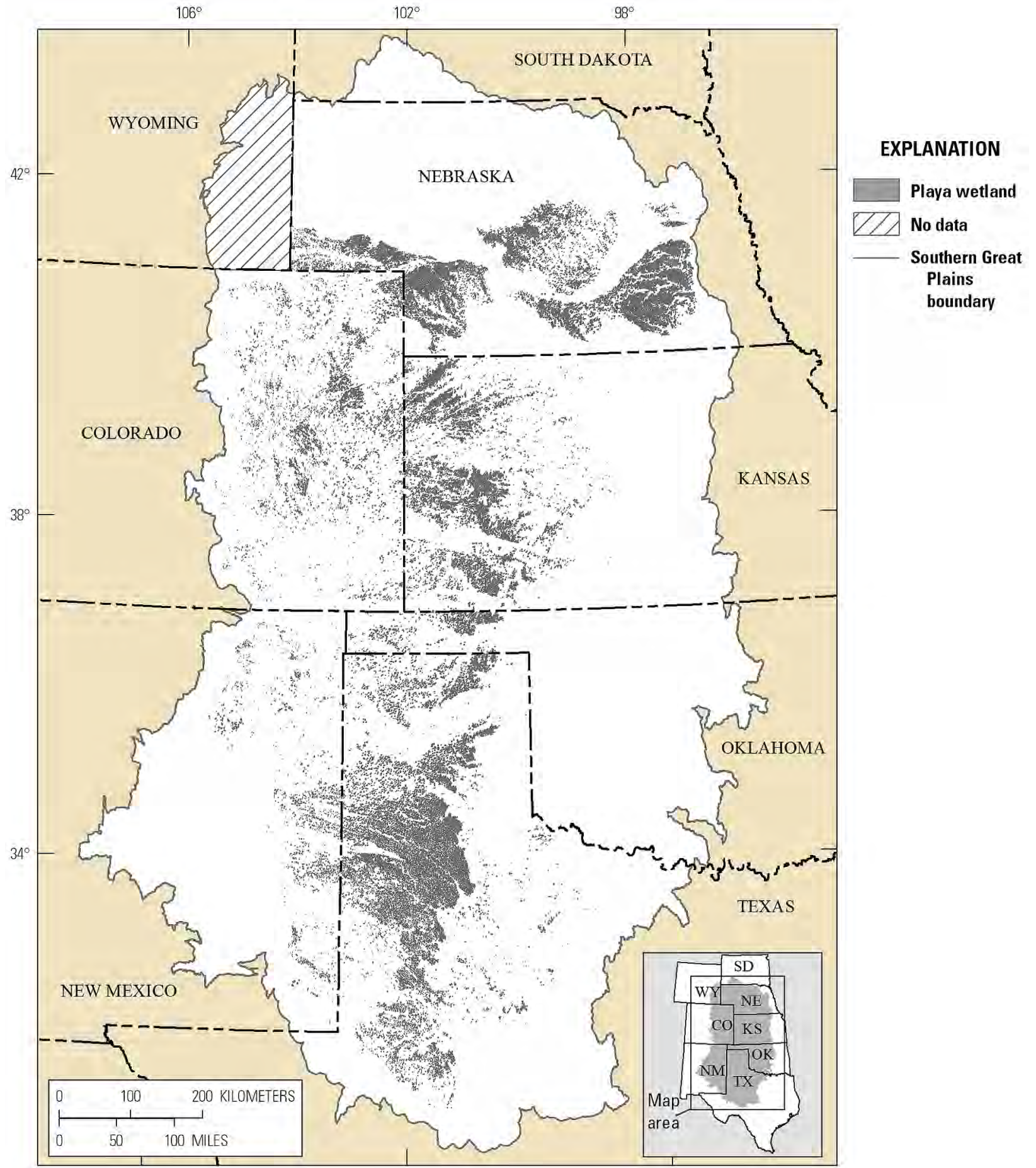

Figure 9-1. Baseline distribution of playa wetlands in the Southern Great Plains. Data on the occurrence of playa wetlands in Wyoming were not available. 


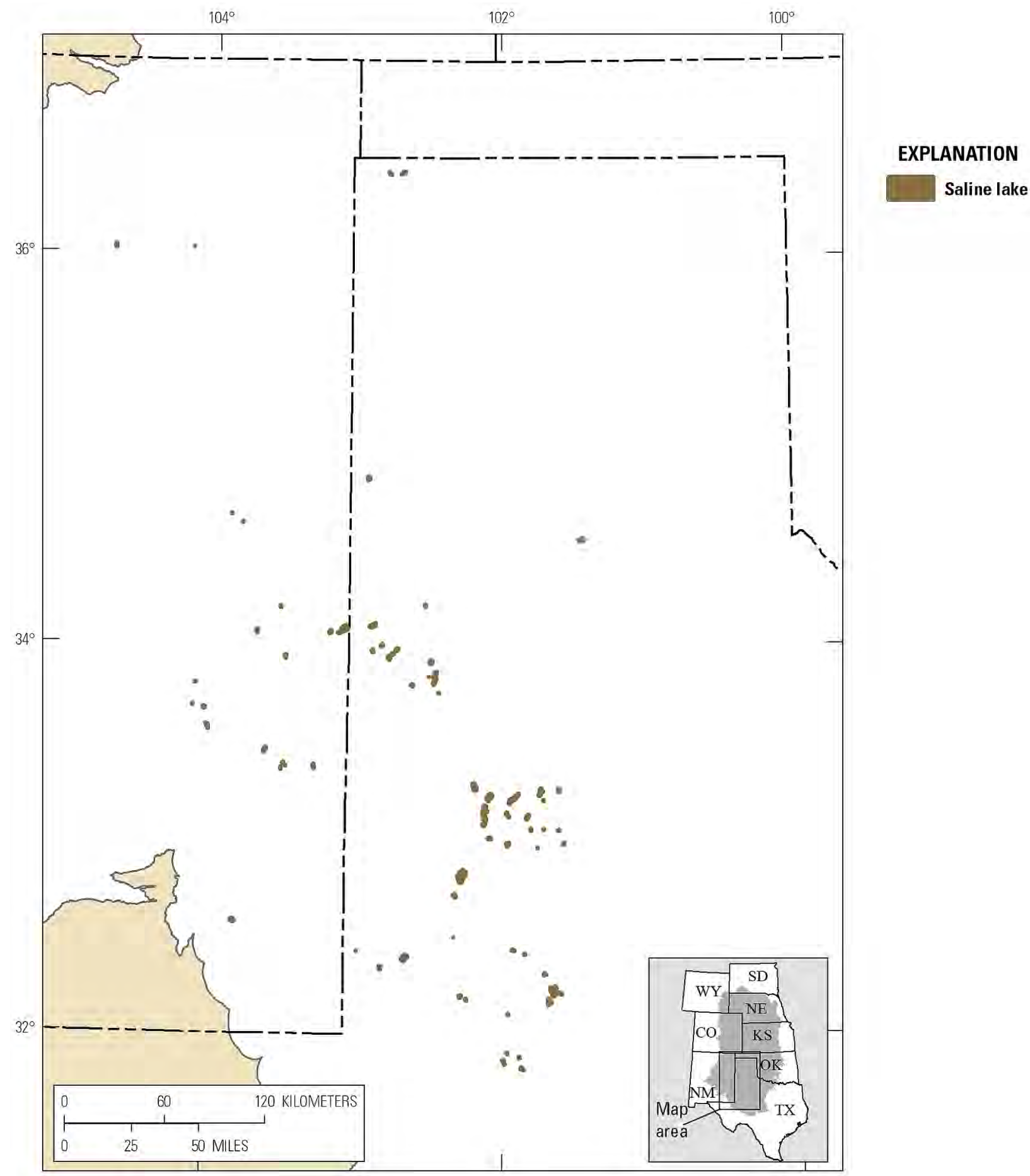

Figure 9-2. Baseline distribution of saline lakes in the Southern Great Plains. 


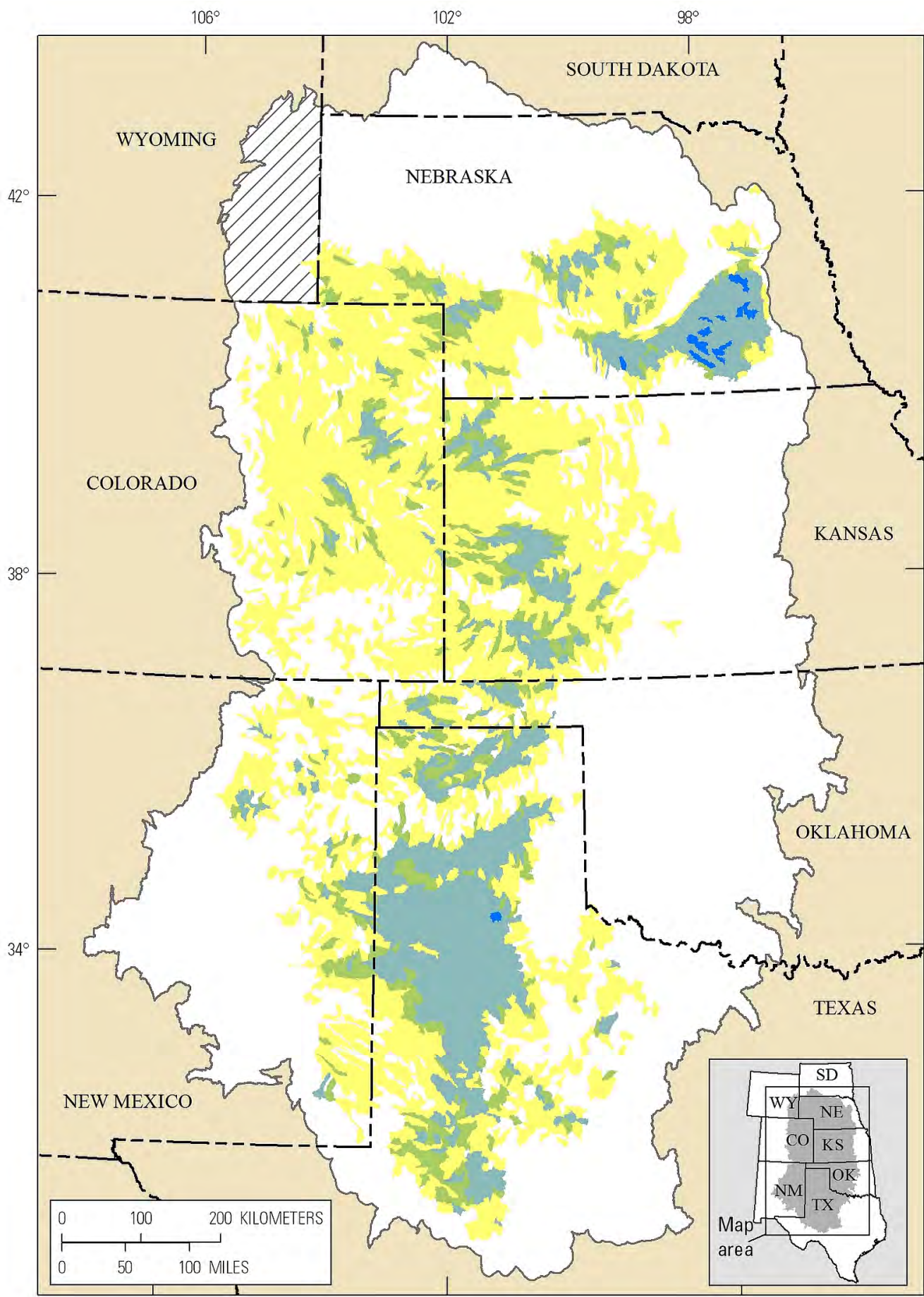

EXPLANATION

Percentage of watershed

$\square>0$ to 0.5

$\square>0.5$ to 1.0

$>1.0$ to 10.0

$>10.0$ to 17.4

Z7 No data

Figure 9-3. Area of baseline playa wetlands as a percentage of sixth-level watershed in the Southern Great Plains. Data on the occurrence of playa wetlands in Wyoming were not available. 
Where does existing development pose the greatest threat to playa wetlands and saline lakes, and where are the large, relatively undeveloped areas (figs. 9-4 to 9-6)?

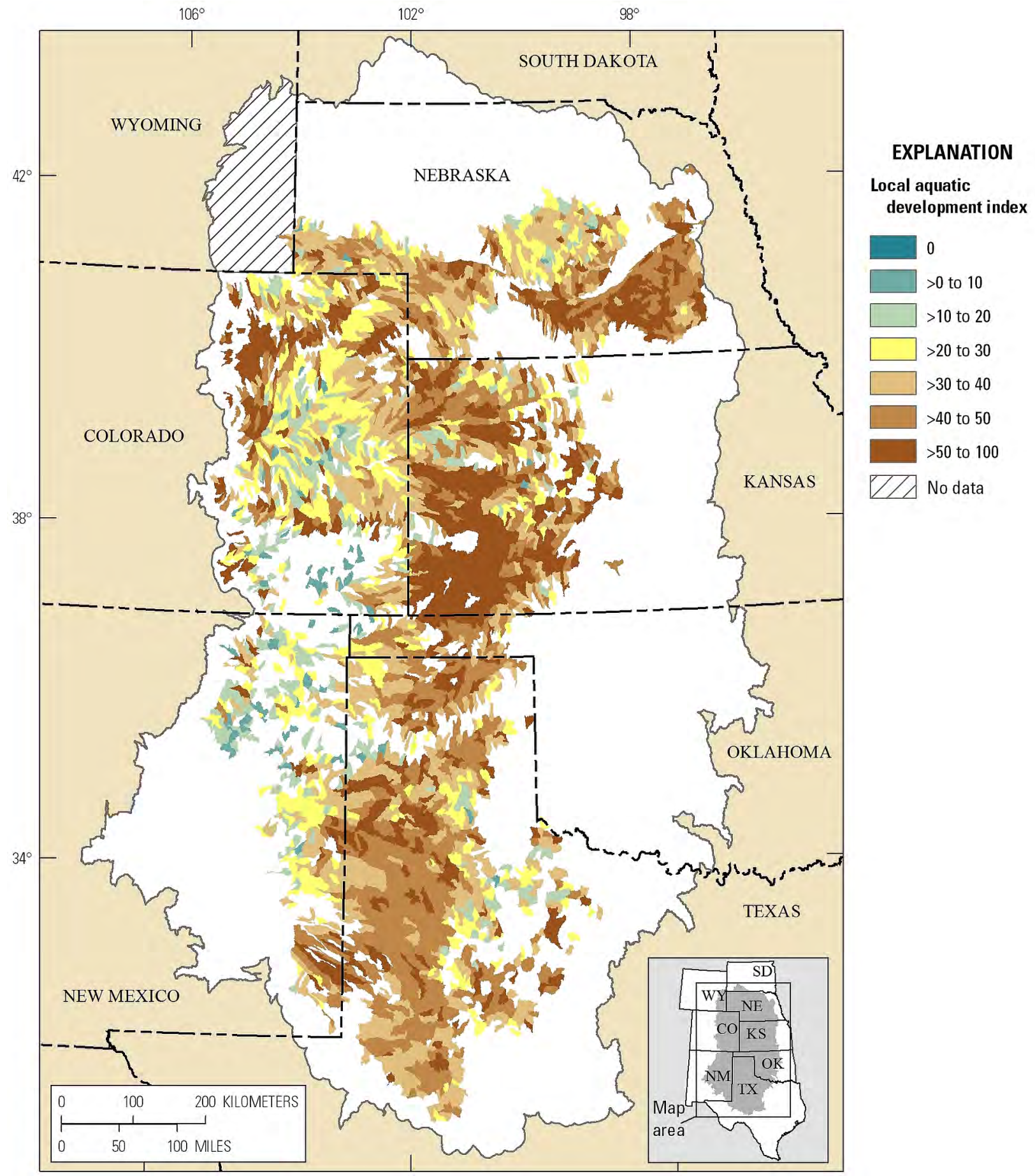

Figure 9-4. Local aquatic development index for baseline playa wetlands, summarized by sixth-level watershed, in the Southern Great Plains. Data on the occurrence of playa wetlands in Wyoming were not available. 


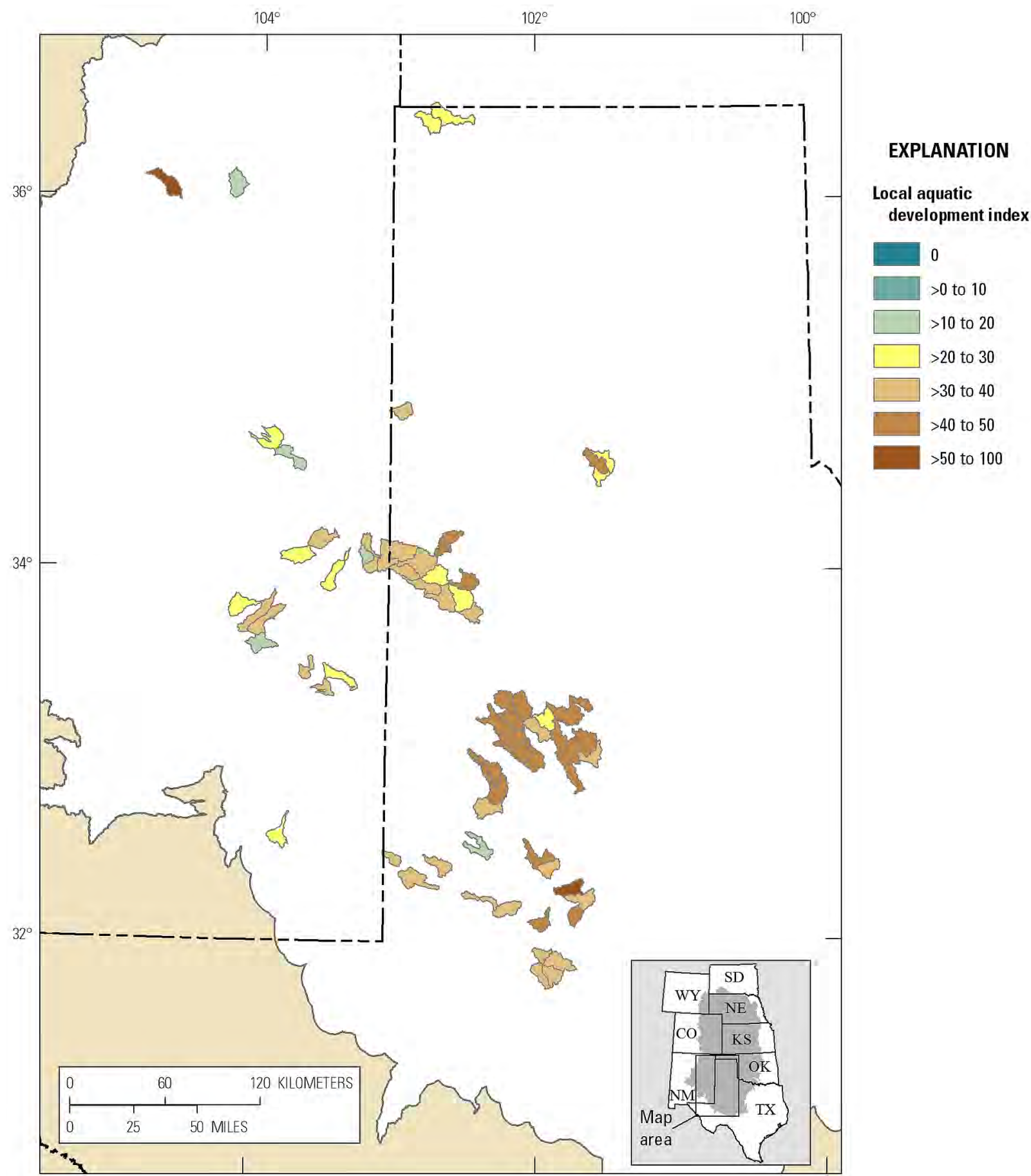

Figure 9-5. Local aquatic development index for baseline saline lakes, summarized by sixth-level watershed, in the Southern Great Plains. 

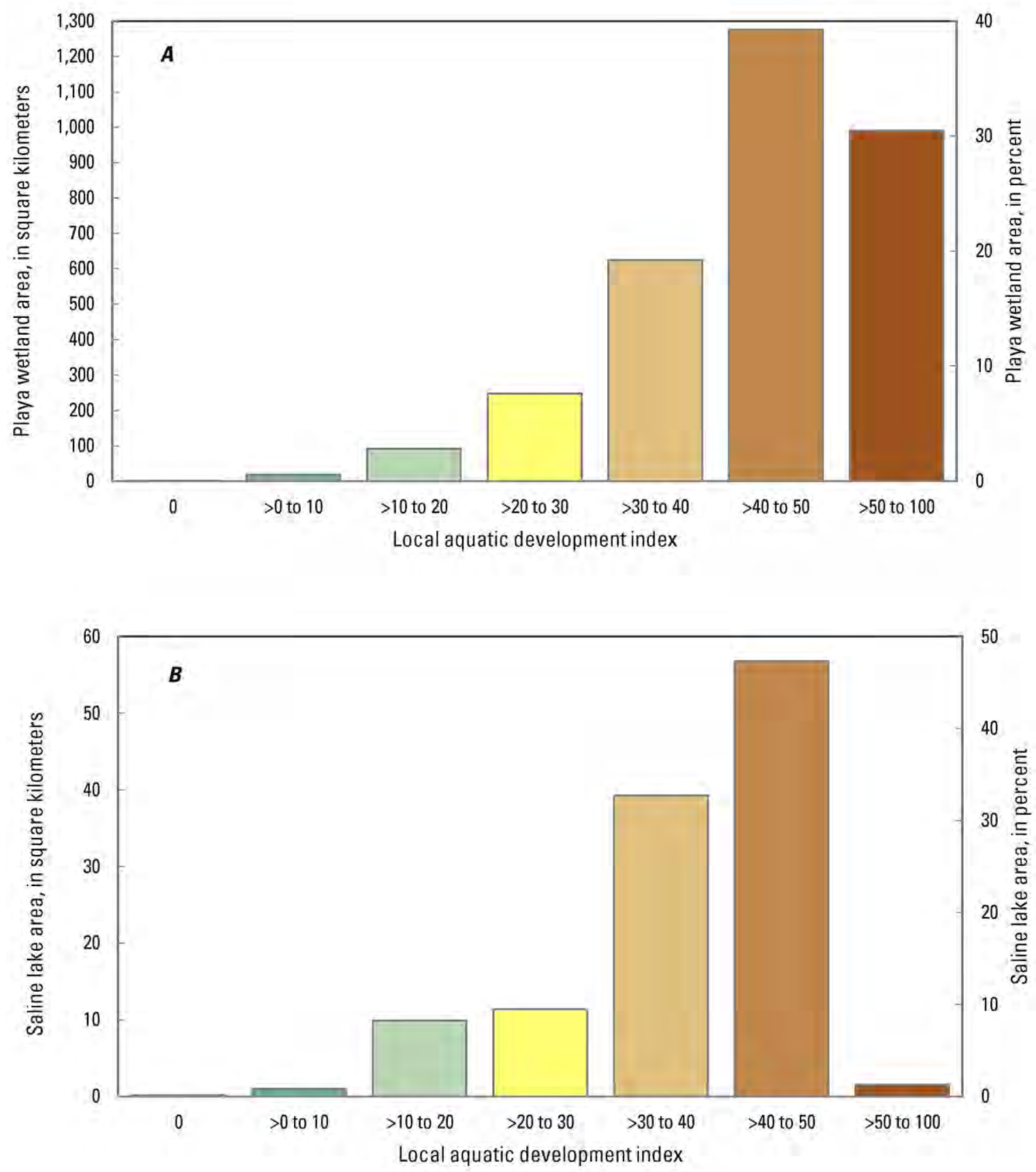

Figure 9-6. Area of $(A)$ playa wetlands and $(B)$ saline lakes by local aquatic development index class in the Southern Great Plains. Data on the occurrence of playa wetlands in Wyoming were not available. 
How has development fragmented playa wetlands and saline lakes (fig. 9-7)?
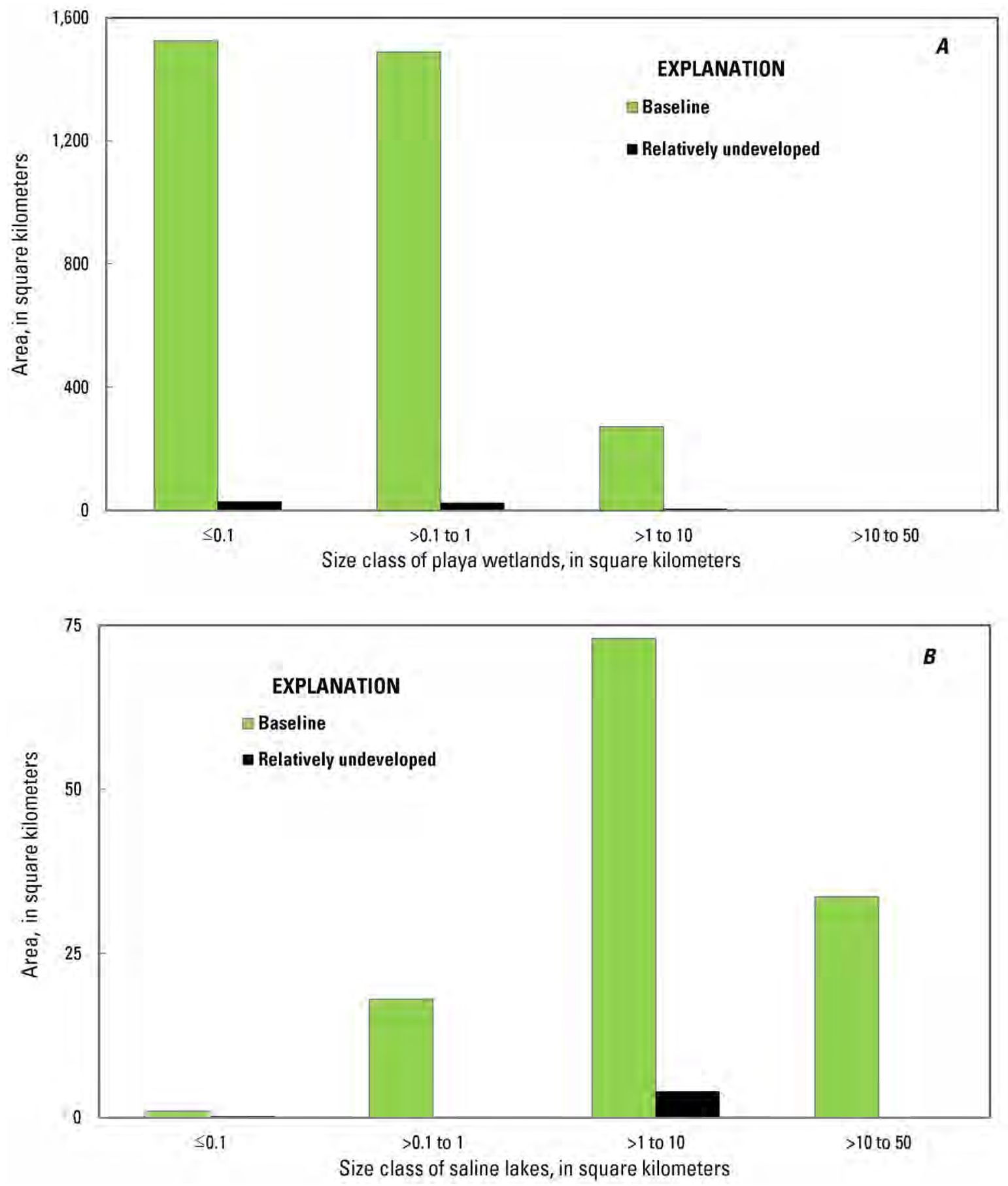

Figure 9-7. Area of $(A)$ playa wetlands and $(B)$ saline lakes in the Southern Great Plains as a function of patch size for baseline and relatively undeveloped conditions (local aquatic development index score $\leq 20$ ). Data on the occurrence of playa wetlands in Wyoming were not available. 
Where are the watersheds with the highest overall landscape-level rank for playa wetlands and saline lakes (fig. 9-8)?

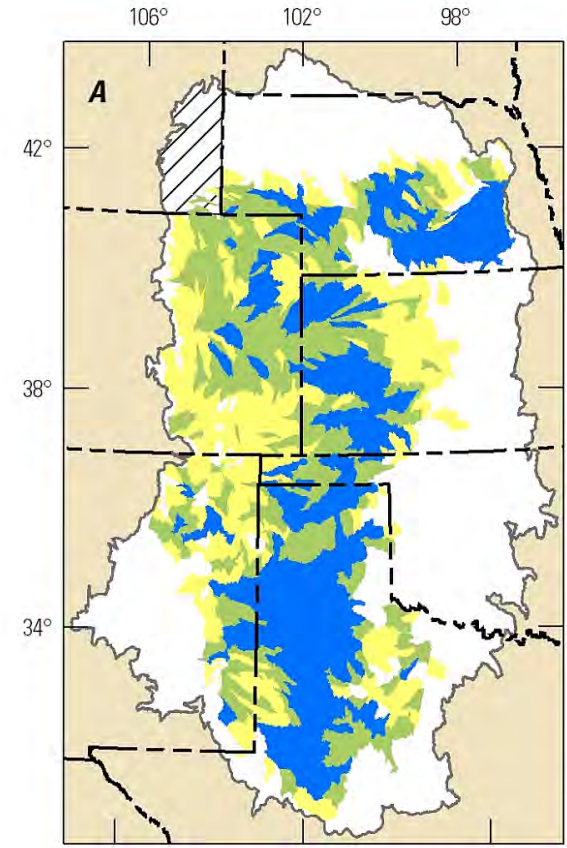

$0 \quad 100200$ KILOMETERS

1,1

$0 \quad 50100$ MILES

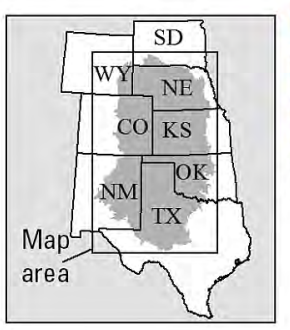
in percent

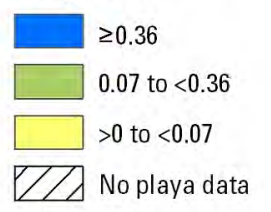

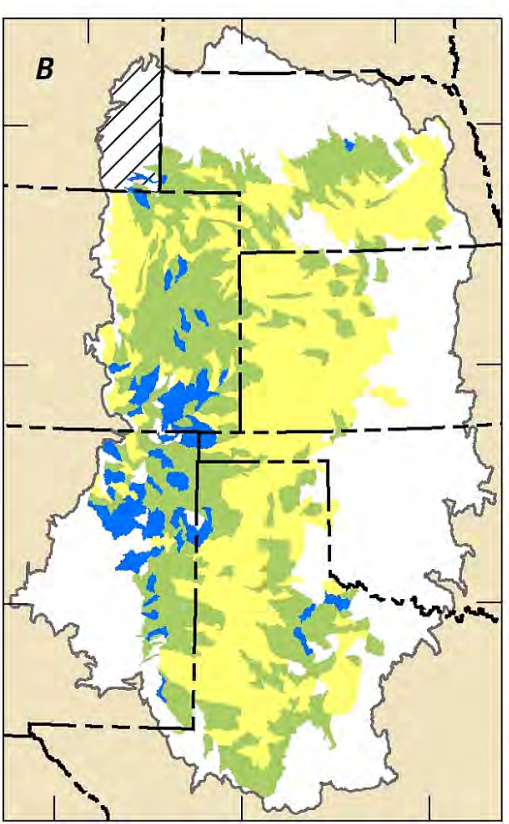

EXPLANATION

A. Landscape-level area,
B. Landscape-level development

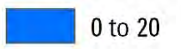

$\square>20$ to 40

$>40$

P/A No playa data

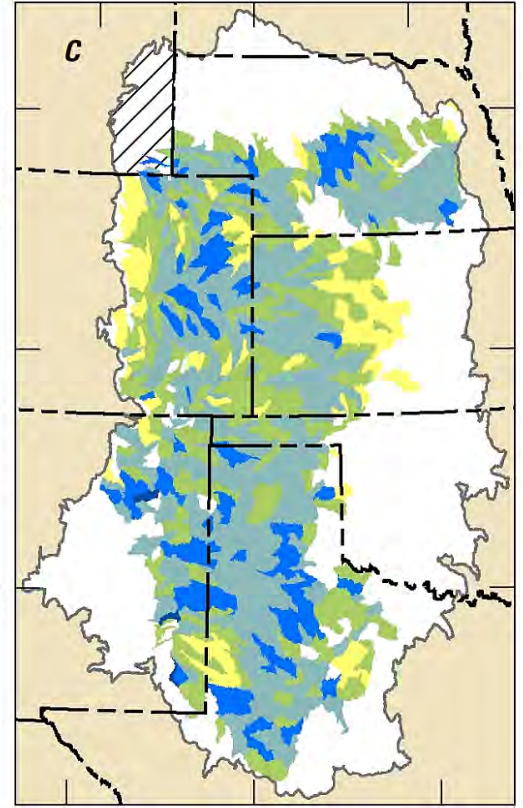

C. Landscape-level rank

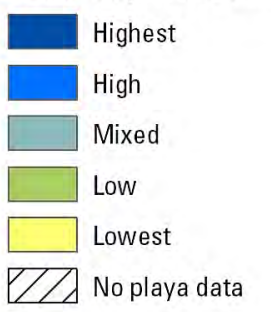

Figure 9-8. Landscape-level summaries for playa wetlands and saline lakes in the Southern Great Plains. Overall landscape-level rank $(C)$ is derived from $(A)$ landscape-level area and $(B)$ landscape-level development, summarized by fifth-level watershed (see table 9-3). Highest overall landscape-level rank corresponds to the largest landscape-level area and the lowest landscape-level development. Lowest overall landscape-level rank corresponds to the smallest landscape-level area and highest landscape-level development. Landscape-level ranks are not intended as standalone summaries and are best interpreted in conjunction with the geospatial datasets used to address core management questions. Data on the occurrence of playa wetlands in Wyoming were not available. 


\section{Summary}

- There are approximately 97,000 mapped playas in the SGP, distributed from the Nebraska Rainwater Basin through the Texas panhandle (figs. 9-1 and 9-3). Total surface area is approximately 3,314 square kilometers $\left(\mathrm{km}^{2} ; 1,279\right.$ square miles $\left.\left[\mathrm{mi}^{2}\right]\right)$ or 0.3 percent of the SGP. There are 105 mapped saline lakes in the SGP (51 of which are named), primarily in the Texas panhandle and adjacent portions of New Mexico (fig. 9-2). The number of saline lakes depends on whether adjacent waterbodies separated by roads, dikes, or other barriers are considered a single lake or separate lakes. Because we lack information on the hydrological connectivity among adjacent saline lakes, we retained each lake as a separate polygon. Total surface area is approximately $126 \mathrm{~km}^{2}\left(48 \mathrm{mi}^{2}\right)$.

- Only 3.4 percent of playas are relatively undeveloped (local aquatic development index [local ADI] score $\leq 20$ ), and 70 percent of playas have experienced moderate to high levels of development (local ADI score $>40$ ) (fig. 9-6A). Most relatively undeveloped playas occur in shortgrass prairie (fig. 9-4).

- Only 9 percent of saline lakes are relatively undeveloped, and 48 percent of saline lakes have experienced moderate to high levels of development (fig. 9-6B).

- The average area of playas is $0.03 \mathrm{~km}^{2}\left(0.01 \mathrm{mi}^{2}\right)$, and the largest playa is $9.5 \mathrm{~km}^{2}\left(3.7 \mathrm{mi}^{2}\right)$ (fig. 9-7). The average area of saline lakes is $1.2 \mathrm{~km}^{2}\left(0.5 \mathrm{mi}^{2}\right)$ and the largest is $22.5 \mathrm{~km}^{2}\left(8.7 \mathrm{mi}^{2}\right)$.

- Because we lack information on the historical distribution of playas and saline lakes across the entire SGP, we could not evaluate how development has decreased their occurrence. In addition, because many playas are located in agricultural settings, local information is needed to evaluate the ecological condition of playas.

- Playas in watersheds with high overall landscapelevel rank occurred in the Rainwater Basin, eastern portions of Colorado and New Mexico, and the Texas Panhandle. This area has some of the highest concentrations of playas in the ecoregion despite limited surface water (fig. 9-8). There were no watersheds with both the highest landscape-level area and the lowest landscape-level development; consequently, there were no watersheds in the highest overall landscape-level rank.

\section{References Cited}

Allen, B.L., 2005, New Mexico's ice ages: New Mexico Museum of Natural History and Science Bulletin, v. 28, p. $107-114$.

Andrei, A.E., Smith, L.E., Haukos, D.A., and Surles, J.G., 2008, Habitat use by migrant shorebirds in saline lakes of the Southern Great Plains: Journal of Wildlife Management, v. 72, no. 1, p. 246-253.

Assal, T.J., Melcher, C.P., and Carr, N.B., eds., 2015, Southern Great Plains Rapid Ecoregional Assessment—Pre-assessment report: U.S. Geological Survey Open-File Report 2015-1003, 284 p., accessed September 2015 at https://doi.org/10.3133/ ofr20151003.

Burris, Lucy, and Skagen, S.K., 2013, Modeling sediment accumulation in North American playa wetlands in response to climate change, 1940-2100: Climatic Change, v. 117, no. $1-2$, p. $69-83$.

Collins, S.D., Heinntzman, L.J., Starr, S.M., Wright, C.K., Henebry, G.M., and McIntyre, N.E., 2014, Hydrological dynamics of temporary wetlands in the Southern Great Plains as a function of surrounding land use: Journal of Arid Environments, v. 109, p. 6-14.

Friend, Milton, 1982, Playas and wildlife disease: Madison, Wis., U.S. Fish and Wildlife Service, 93 p.

Gurdak, J.J., and Roe, C.D., 2009, Recharge rates and chemistry beneath playas of the High Plains aquifer-A literature review and synthesis: U.S. Geological Survey Circular 1333, 39 p., accessed September 30, 2013, at http://pubs.usgs.gov/circ/1333/.

Hall, S.A., 2001, Geochronology and paleoenvironments of the glacial-age Tahoka Formation, Texas and New Mexico: New Mexico Geology, v. 23, no. 3, p. 71-77.

Haukos, D.A., and Smith, L.M., 1994, Importance of playa wetlands to biodiversity of the southern High Plains: Landscape and Urban Planning, v. 28, p. 83-98.

Horn, J.W., Arnett, E.B., and Kunz, T.H., 2008, Behavioral responses of bats to operating wind turbines: Journal of Wildlife Management, v. 72, no. 1, p. 123-132.

Irwin, R.J.; Connor, P.J.; Baker, Denise; Dodson, Susan; and Littlefield, C.D., 1996, Playa lakes of the Texas High Plains-A contaminants survey and assessment of biological integrity: Arlington, Tex., U.S. Fish and Wildlife Service, Ecological Services Field Office, 94 p. [Also available at http://www.fws.gov/southwest/es/arlingtontexas/pdf/ Playa_Lakes_1996.pdf.] 


\section{Southern Great Plains Rapid Ecoregional Assessment-Volume 1. Ecological Communities}

Playa Lakes Joint Venture, 2014, Maps of probable playa locations: Playa Lakes Joint Venture, accessed November 2013 at http://pljv.org/for-habitat-partners/mapsand-data/maps-of-probable-playas/ [shapefile] and http:// www.pljv.org/PPv4_MapBook/PPv4_release_notes.pdf [release notes].

Samson, F.B., and Knopf, F.L., eds., 1996, Prairie conservation-Preserving North America's most endangered ecosystem: Washington, D.C., Island Press, 339 p.

Smith, L.M., 2003, Playas of the Great Plains: Austin, Tex., University of Texas Press, $257 \mathrm{p}$.
Stewart, G.B., Pullin, A.S., and Coles, C.F., 2005, Effects of wind turbines on bird abundance: Collaboration for Environmental Evidence, CEE review 04-002 (SR4), accessed November 2013 at http://www.environmentalevidence.org/SR4.html.

Tiner, R.W., 2003, Geographically isolated wetlands of the United States: Wetlands, v. 23, no. 3, p. 494-516.

Tsai, J.-T., Venne, L.S., McMurry, S.T., and Smith, L.M., 2007, Influences of land use and wetland characteristics on water loss rates and hydroperiods of playas in the southern High Plains, USA: Wetlands, v. 27, p. 683-692. 


\section{Chapter 10. Prairie Streams and Rivers}

\section{Introduction}

Prairie streams and rivers of the Southern Great Plains (SGP) vary widely in geomorphology, streamflow pattern, and biota (Poff and Ward, 1989; Dodds and others, 2004; Costigan, 2013). Historically, prairie streams were dynamic and alternated between flooding and drying. Intermittent streamflow is characteristic of many streams throughout the SGP (Dodds and others, 2004). Perennial prairie streams in the SGP include rivers, which are simply large streams. Streamflow dynamics are influenced by snowmelt in the west and by convective storms in the central and eastern regions. Climatic dynamics result in high variation and low predictability of streamflow (Poff and Ward, 1989). Many aquatic species are adapted to the intermittent nature of prairie streams and can rapidly recolonize previously desiccated reaches. The rate of recovery from desiccation is influenced by the distance to source population and the disturbance intensity and frequency (Dodds and others, 2004).

Primary anthropogenic change agents affecting prairie streams include agriculture, energy development, and urbanization (Dodds and others, 2004). Hydrological regimes are altered by dams, water diversions, and pumping groundwater to the surface, which can fragment streams and alter the persistence of perennial-pool refugia and underlying aquifers (Falke and others, 2011; Costigan and Daniels, 2012). Erosion from surrounding croplands, intensive livestock grazing along embankments,

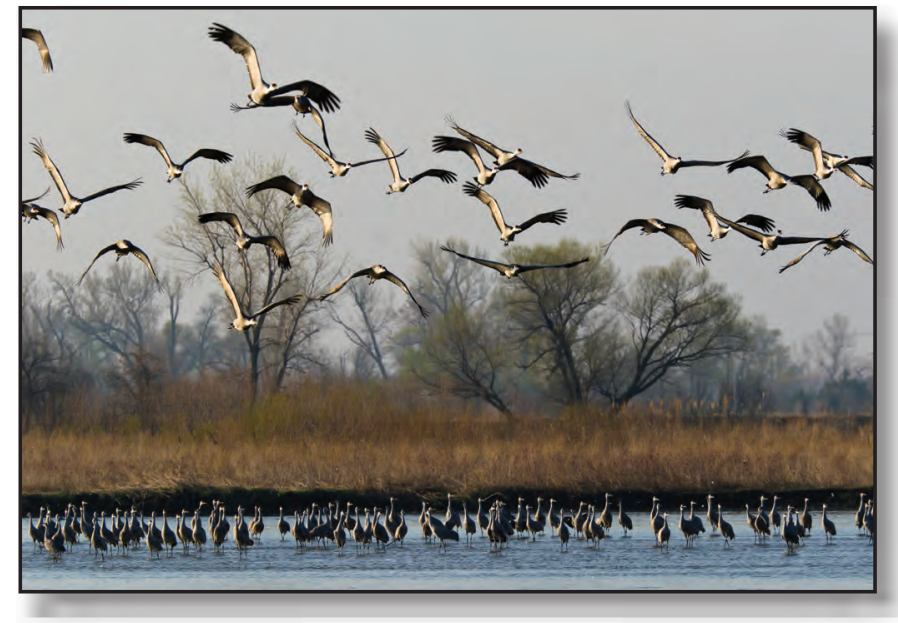

Platte River, Nebraska. Photograph by Larry Crist, U.S. Fish and Wildlife Service (Creative Commons Attribution 2.0 Generic). and channelization of streams and rivers can degrade water quality through sedimentation and contamination. Energy development can lead to depletion and contamination of surface water and groundwater, particularly where hydraulic fracturing is prevalent. Transportation corridors and road crossings can also fragment streams and rivers. Although the historical role of fire in the SGP is poorly understood, active fire suppression and intensive grazing can diminish fire frequency, which can increase fire severity and concomitant sedimentation of streams. Invasive species that can affect stream hydrology and function include woody riparian species and the escape of nonnative fishes from artificial impoundments into streams (Schrank and others, 2001; Falke and Gido, 2006). Finally, changing climatic conditions could affect the dynamics and function of prairie streams (Falke and others, 2011).

The cumulative effects of natural and anthropogenic disturbances can decrease habitat for aquatic species, isolate populations, and eliminate refugia. For example, large-river minnow species such as the Arkansas River shiner are very sensitive to altered flows and habitat fragmentation (Luttrell and others, 1999; Perkin and others, 2010; Perkin and Gido, 2012). In addition, functional connectivity for aquatic species (in the sense of Perkin and Guido, 2012) can be decreased by poorly designed or inadequately maintained road and railroad stream crossings (Warren and Pardew, 1998; Ottburg and Blank, 2015). Additional background information can be found in the SGP pre-assessment report (Assal and others, 2015).

\section{Rapid Ecoregional Assessment Components Evaluated for Prairie Streams and Rivers}

The key ecological attributes and change agents addressed by core management questions for prairie streams and rivers include amount and distribution, landscape structure (patch size, connectivity), and development (tables 10-1 and 10-2). Fire occurrence and climate change were evaluated for the entire SGP (see chapter 3, "Change Agents"), and invasive woody species were evaluated for riparian areas (see chapter 8, "Riparian and Nonplaya Wetlands"). Overall landscape-level ranking variables are summarized in table $10-3$. The core and integrated management questions are listed in table 10-4. 
Table 10-1. Key ecological attributes and associated indicators used to address core management questions for prairie streams and rivers for the Southern Great Plains Rapid Ecoregional Assessment.

\begin{tabular}{lll}
\hline \multicolumn{1}{c}{ Attributes } & Variables & \multicolumn{1}{c}{ Indicators $^{1}$} \\
\hline Amount and distribution & Total length & Baseline distribution and total length of streams $^{3}$ \\
Landscape structure & Patch size & Segment length of baseline perennial stream segments ${ }^{3}$ \\
Landscape dynamics & Fire occurrence & See chapter 3, "Change Agents" \\
\hline
\end{tabular}

${ }^{1}$ See chapter 2, "Methods Overview," and appendix A for methods and datasets used.

${ }^{2}$ Baseline distribution is determined by the most current regional data available.

${ }^{3}$ Summarized by sixth-level watershed.

Table 10-2. Anthropogenic change agents and associated indicators used to address core management questions for prairie streams and rivers for the Southern Great Plains Rapid Ecoregional Assessment.

\begin{tabular}{|c|c|c|}
\hline Change agents & Variables & Indicators $^{1}$ \\
\hline Development & $\begin{array}{l}\text { Barriers affecting patch size and } \\
\text { structural connectivity }\end{array}$ & $\begin{array}{l}\text { Number of dams and potential barriers (points of diversion and road and railroad } \\
\text { stream crossings) in perennial streams, summarized by sixth-level watershed }\end{array}$ \\
\hline Fire & Fire occurrence & See chapter 3, "Change Agents" \\
\hline Invasive species & $\begin{array}{l}\text { Occurrence and potential for woody } \\
\text { species expansion }\end{array}$ & See chapter 8, "Riparian Areas and Nonplaya Wetlands" \\
\hline
\end{tabular}

${ }^{1}$ See chapter 2, "Methods Overview," and appendix A for methods and datasets used.

${ }^{2}$ Relatively undeveloped: aquatic development index less than or equal to 20 .

Table 10-3. Landscape-level variables used to address the integrated management question for prairie streams and rivers. Ranks for landscape-level density and development were combined into an overall landscape-level rank for the Southern Great Plains Rapid Ecoregional Assessment.

$[<$, less than; $>$, greater than $]$

\begin{tabular}{llcc}
\hline $\begin{array}{c}\text { Landscape- } \\
\text { level variables }\end{array}$ & \multicolumn{1}{c}{ Description } & Lowest & Relative rank $^{2}$ \\
\cline { 2 - 4 } Density & $\begin{array}{c}\text { Ratio of perennial stream length (kilometers) to watershed area } \\
\text { (square kilometers), by fifth-level watershed }\end{array}$ & $0.004-<0.391$ & $0.391-<0.662$ \\
Development & $\begin{array}{c}\text { Mean aquatic development index score for perennial and intermittent } \\
\text { streams, summarized by fifth-level watershed }\end{array}$ & $0-20$ & $>0.662$ \\
\hline
\end{tabular}

\footnotetext{
${ }^{1}$ See chapter 2, "Methods Overview," and appendix A for methods and datasets used.
}

${ }^{2}$ Ranking breakpoints for landscape-level densities were determined from equal subsets of the data. Ranking breakpoints for the aquatic development index were standardized for all aquatic conservation elements.

${ }^{3}$ Density refers to drainage density of streams (Horton, 1932).

Table 10-4. Management questions addressed for prairie streams and rivers for the Southern Great Plains Rapid Ecoregional Assessment.

\begin{tabular}{|c|c|}
\hline Core management questions ${ }^{1}$ & Results \\
\hline What is the current distribution of prairie streams and rivers? & Figures $10-1$ to $10^{-3}$ \\
\hline $\begin{array}{l}\text { Where does existing development pose the greatest threat to prairie streams and rivers, and where are the large, relatively } \\
\text { undeveloped areas? }\end{array}$ & Figures $10-4$ to $10-6$ \\
\hline How has development fragmented prairie streams and rivers, and decreased structural connectivity? & Figures $10-7$ and $10-8$ \\
\hline Integrated management question² & Results \\
\hline
\end{tabular}

\footnotetext{
${ }^{1}$ See chapter 11, "Data Gaps, Limitations, and Uncertainty," for management questions that could not be addressed.

${ }^{2}$ See table $10-3$.
} 


\section{Management Questions and Results}

What is the current distribution of prairie streams and rivers (figs. 10-1 to 10-3)?

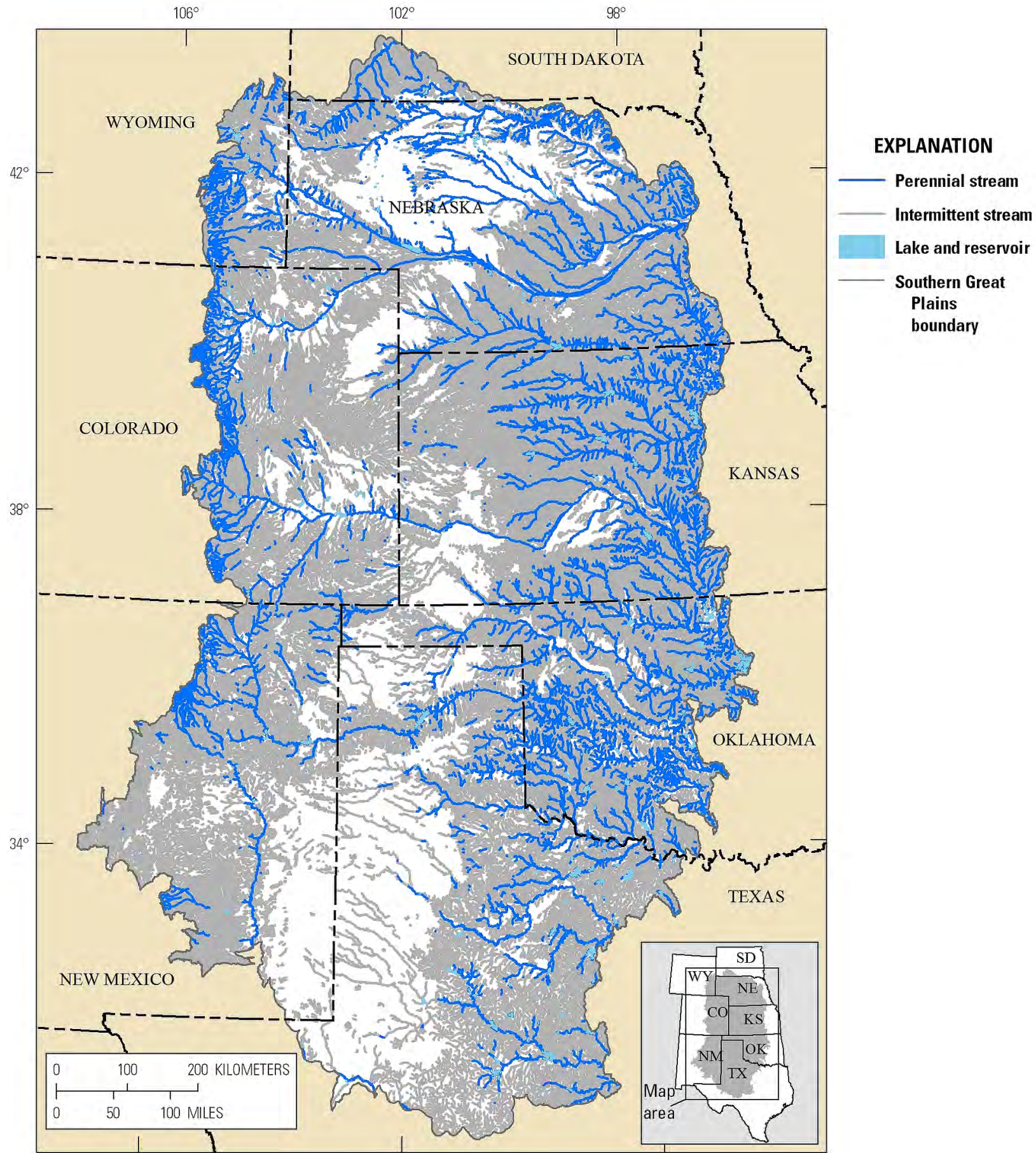

Figure 10-1. Baseline distribution of prairie streams and rivers by hydroperiod (perennial or intermittent) in the Southern Great Plains. 


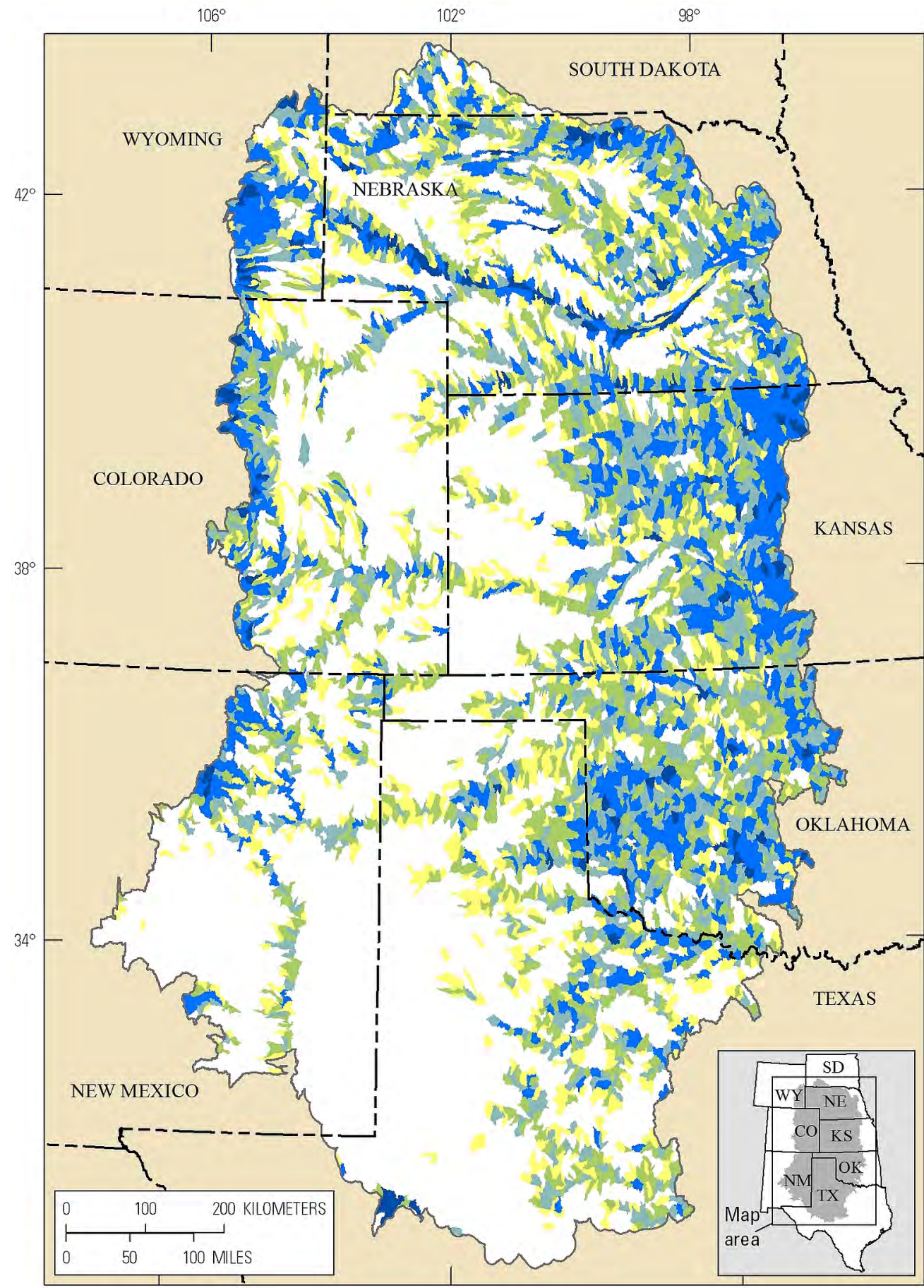

\section{EXPLANATION}

Perennial stream

length, in kilometers

$\square>0$ to 8

$>8$ to 16

$>16$ to 24

$>24$ to 48

$>48$ to 184

Figure 10-2. Total length of perennial streams, by sixth-level watershed, in the Southern Great Plains. 


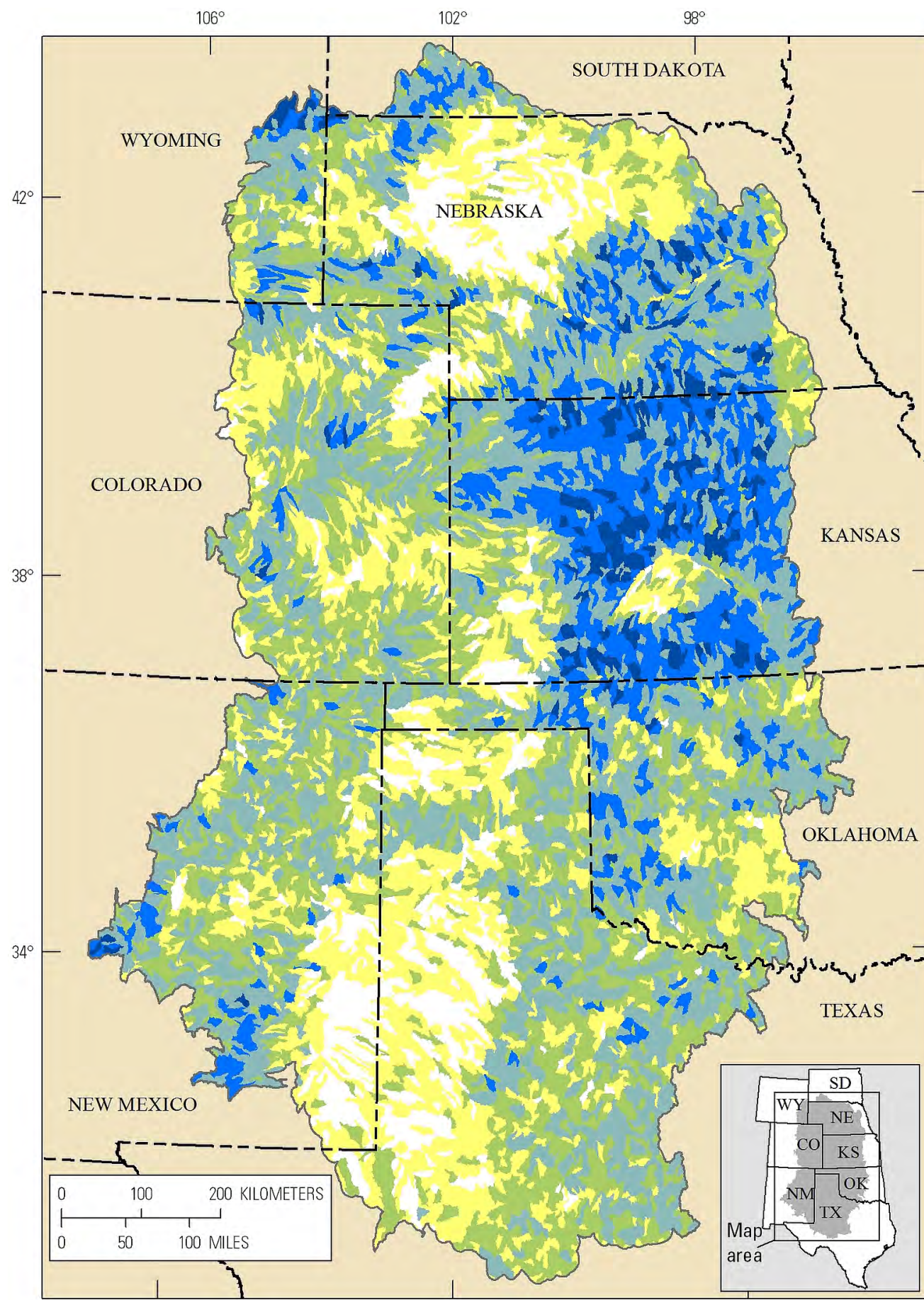

EXPLANATION

Intermittent stream length, in kilometers

$\square>0$ to 25
$>25$ to 50
$>50$ to 100
$>100$ to 150
$>150$ to 314

Figure 10-3. Total length of intermittent streams, by sixth-level watershed, in the Southern Great Plains. 
Where does existing development pose the greatest threat to prairie streams and rivers, and where are the large, relatively undeveloped areas (figs. 10-4 to 10-6)?

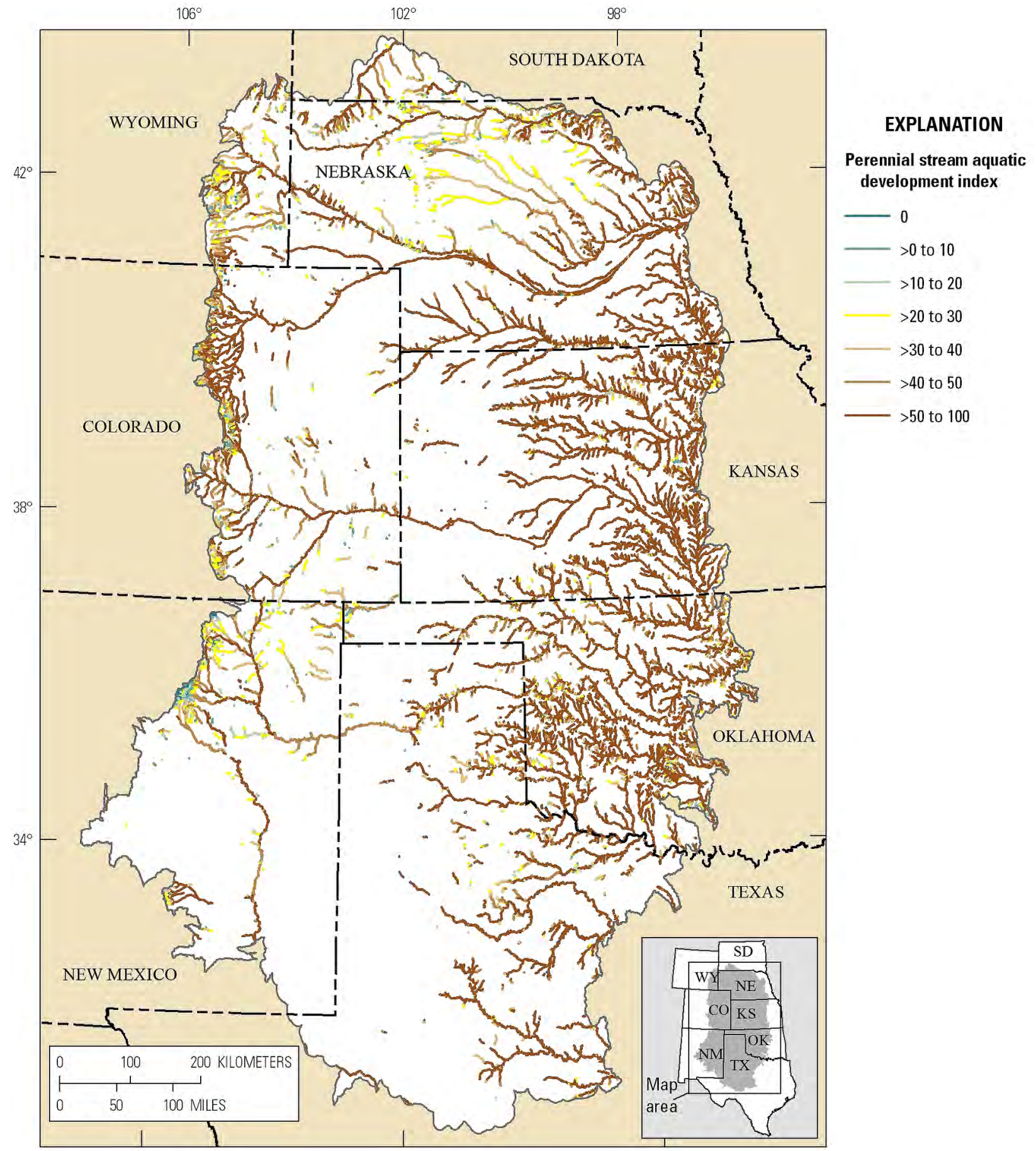

Figure 10-4. Aquatic development index for baseline perennial streams in the Southern Great Plains. 


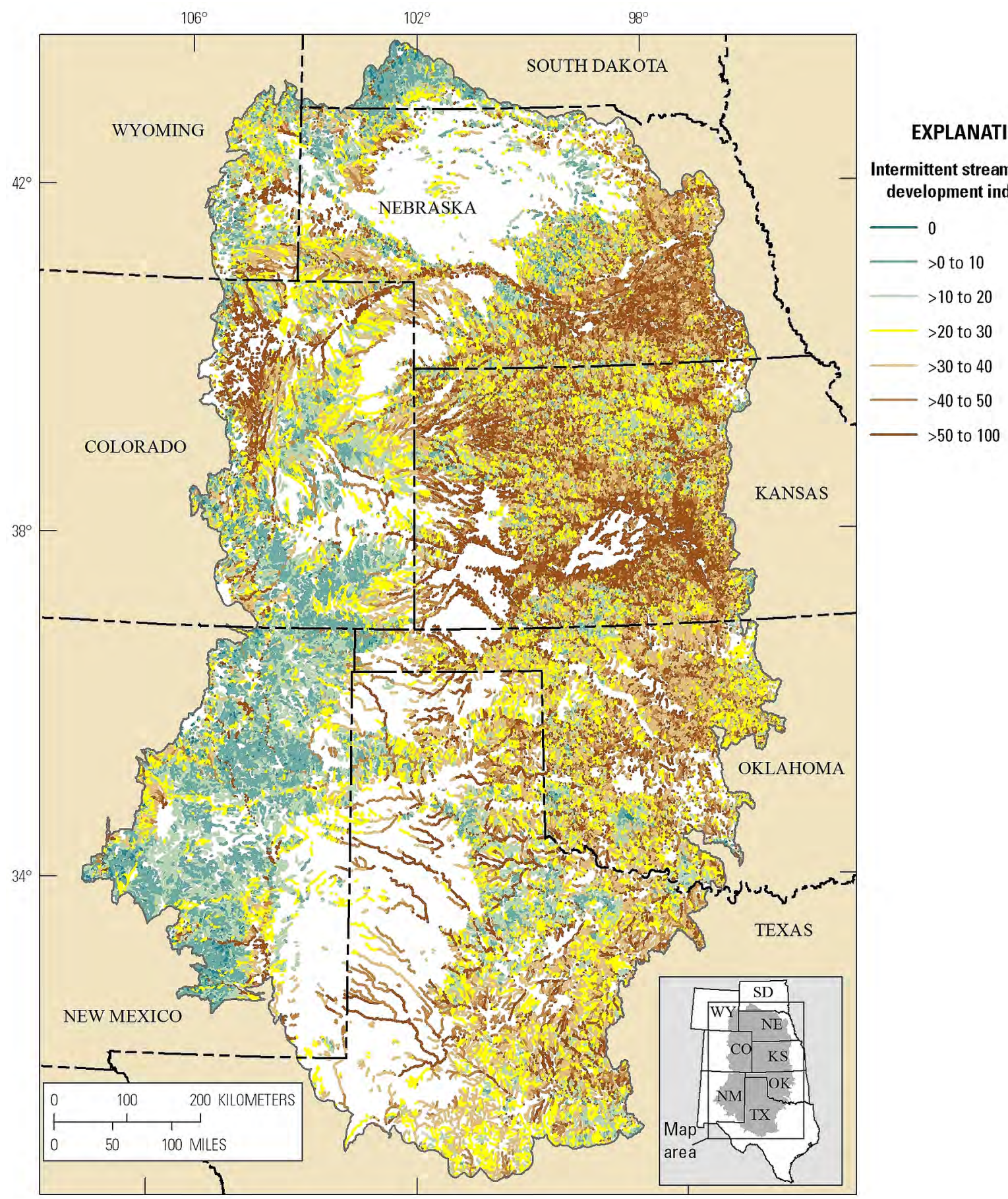

Figure 10-5. Aquatic development index for baseline intermittent streams in the Southern Great Plains. 

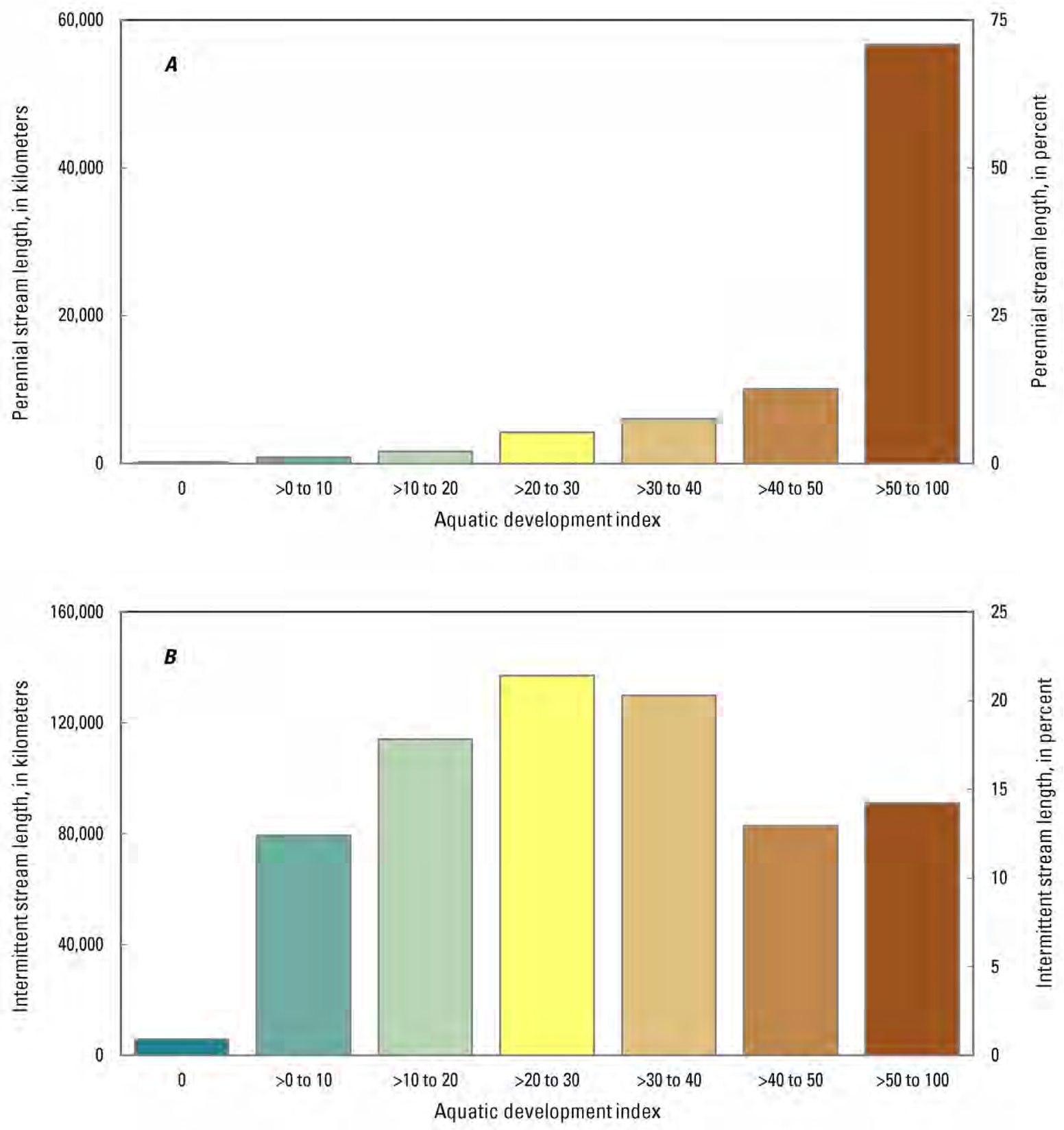

Figure 10-6. Length of prairie streams and rivers by aquatic development index class in the Southern Great Plains. $A$, Perennial streams. $B$, Intermittent streams. 
How has development fragmented prairie streams and rivers, and decreased structural connectivity (figs. 10-7 and 10-8)?

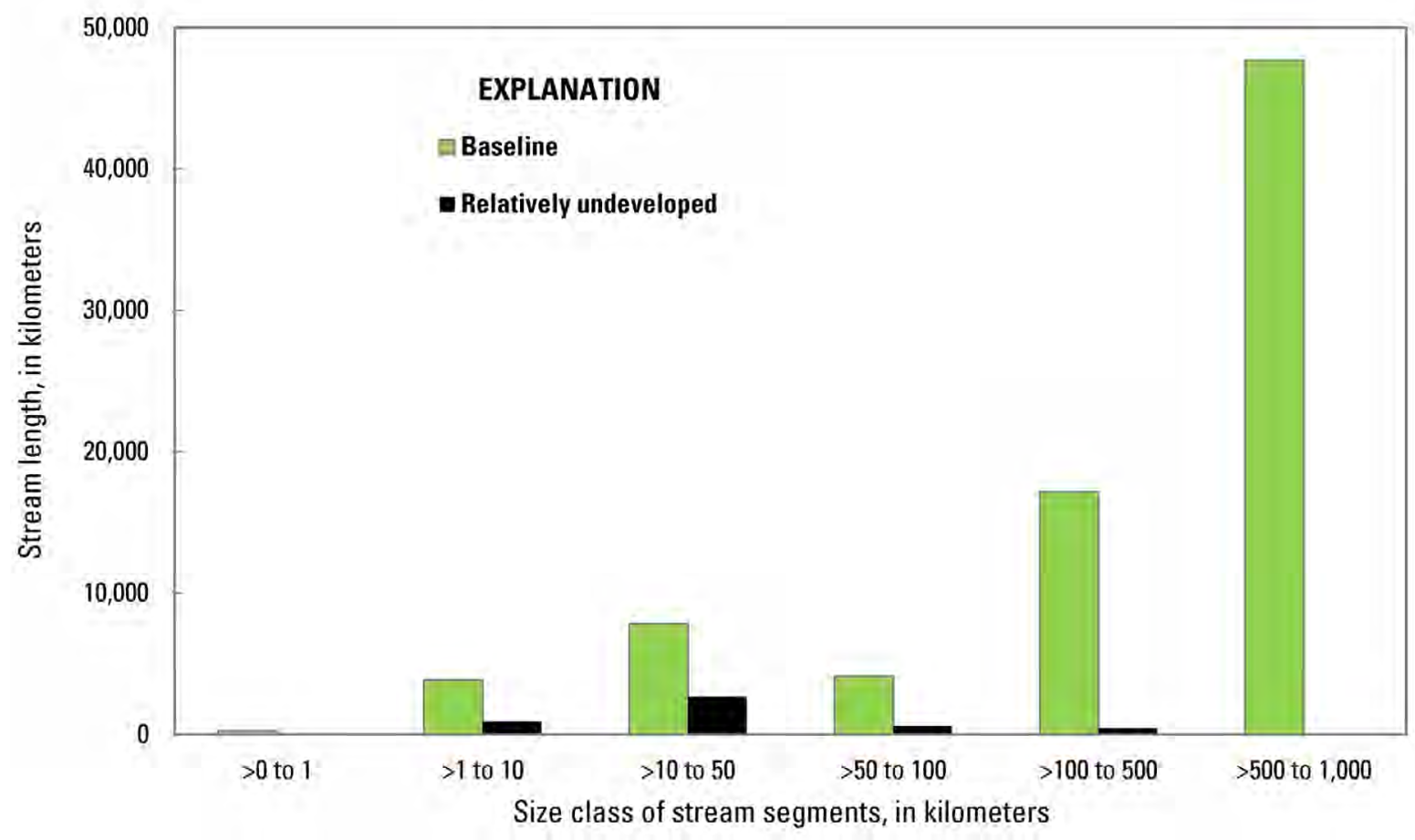

Figure 10-7. Total length of perennial streams in the Southern Great Plains as a function of stream-segment size class for baseline and relatively undeveloped conditions (aquatic development index score $\leq 20$ ). 


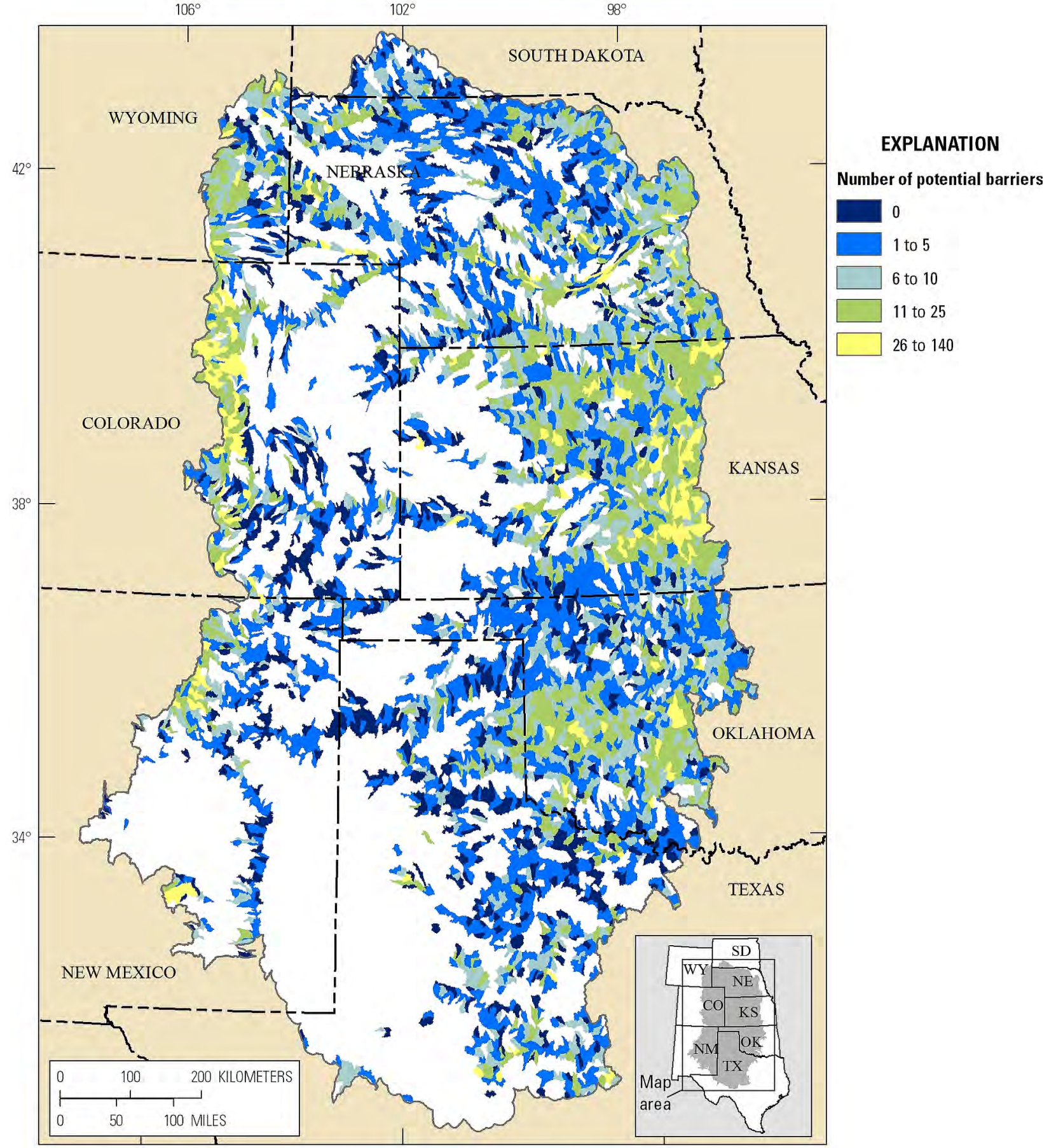

Figure 10-8. Potential barriers (combined dams, diversions, and road and railroad stream crossings) in perennial streams, summarized by sixth-level watershed, in the Southern Great Plains. 


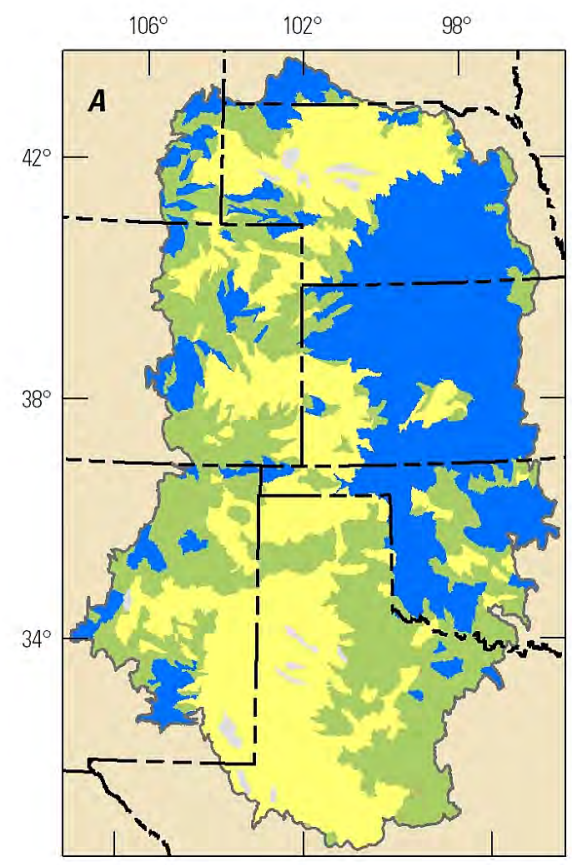

O 100200 KILOMETERS 1,1, $0 \quad 50100$ MILES

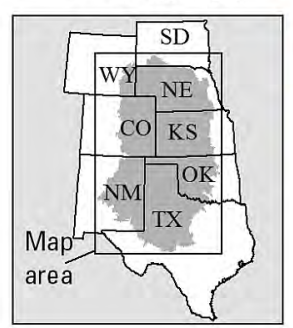

$\geq 0.66$

0.39 to $<0.66$

$>0.004$ to $<0.39$

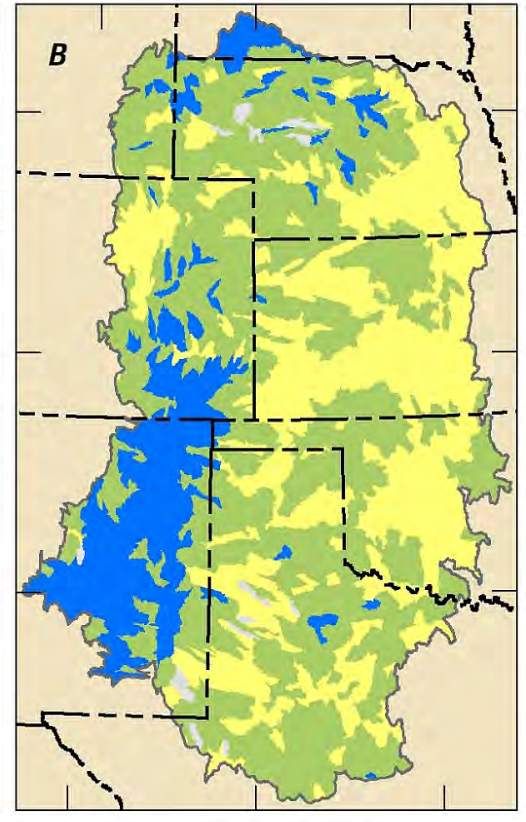

EXPLANATION

A. Landscape-level density

Below threshold
B. Landscape-level development

0 to 20

$>20$ to 40

$>40$

Below threshold

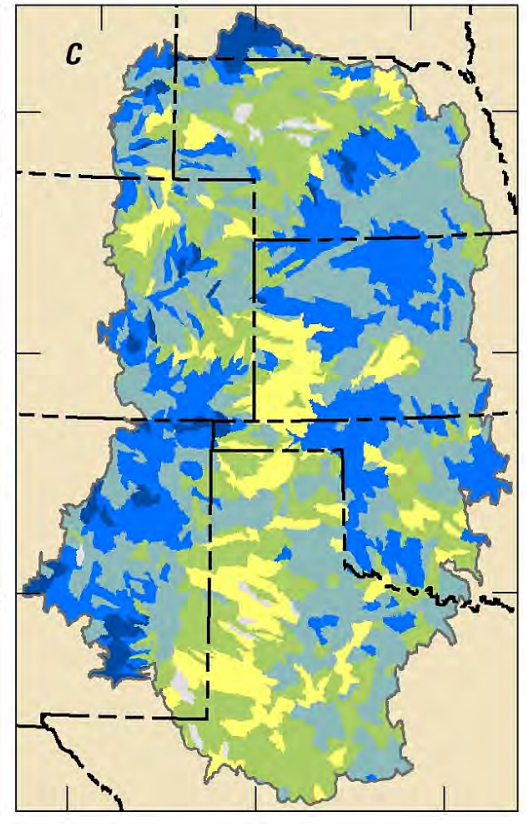

C. Landscape-level rank

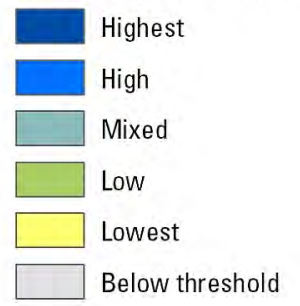

Figure 10-9. Landscape-level summaries for prairie streams and rivers in the Southern Great Plains. Landscape-level rank $(C)$ is derived from $(A)$ landscape-level density and $(B)$ landscape-level development, summarized by fifth-level watershed (table 10-3). Highest overall landscape-level rank corresponds to the highest landscape-level density and the lowest landscape-level development. Lowest overall landscape-level rank corresponds to the lowest landscape-level density and highest development levels. Landscape-level ranks are not intended as standalone summaries and are best interpreted in conjunction with the geospatial datasets used to address core management questions. 


\section{Summary}

- In the SGP, 85 percent of prairie streams are intermittent. Perennial streams are concentrated in the narrow band of western uplands and throughout the eastern portions of the SGP (figs. 10-1 to 10-3). Intermittent streams reach their highest densities in the eastern portion of the SGP, but they are also common in the western and southeastern portions.

- Only 3.5 percent of perennial streams are relatively undeveloped (aquatic development index [ADI] score $\leq 20$ ), whereas 31 percent of intermittent streams are relatively undeveloped (figs. 10-4 to 10-6). More than 71 percent of perennial streams have experienced significant development (ADI score $>50$ ).

- Dams have fragmented perennial streams such that the longest perennial stream segment within a sixth-level watershed is 184 kilometers $(\mathrm{km} ; 114$ miles [mi]) and mean segment length is $17 \mathrm{~km}$ (10.5 mi) (figs. 10-7 and 10-8). Flow has been altered by dams, diversions, and road and railroad stream crossings in 84 percent of sixth-level watersheds containing perennial streams (fig. 10-8).

- Stream segments under baseline conditions generally exceed $500 \mathrm{~km}(311 \mathrm{mi})$, but all of the relatively undeveloped streams are less than $500 \mathrm{~km}$ long (fig. 10-7).

- In general, fifth-level watersheds with the highest landscape-level density (fig. 10-9A) also have experienced high levels of development, leading to generally lower overall landscape-level rank for much of the central and southern portions of the ecoregion (fig. 10-9C).

\section{References Cited}

Assal, T.J., Melcher, C.P., and Carr, N.B., eds., 2015, Southern Great Plains Rapid Ecoregional Assessment-Pre-assessment report: U.S. Geological Survey Open-File Report 2015-1003, 284 p., accessed September 2015 at https://doi.org/10.3133/ ofr20151003.

Costigan, K.H., 2013, Hydrology and geomorphology of select Great Plains rivers: Manhattan, Kans., Kansas State University, Ph.D. dissertation, $114 \mathrm{p}$.

Costigan, K.H., and Daniels, M.D., 2012, Damming the prairie - Human alteration of Great Plains river regimes: Journal of Hydrology, v. 444-445, p. 90-99.
Dodds, W.K., Gido, Keith, Whiles, M.R., Fritz, K.M., and Matthews, W.J., 2004, Life on the edge-The ecology of Great Plains prairie streams: BioScience, v. 54, p. 205-216.

Falke, J.A.; Fausch, K.D.; Magelky, Robin; Aldred, Angela; Durnford, D.S.; Riley, L.K.; and Oad, Ramchand, 2011, The role of groundwater pumping and drought in shaping ecological futures for stream fishes in a dryland river basin of the western Great Plains, USA: Ecohydrology, v. 4, p. 682-697.

Falke, J.A., and Gido, K.B., 2006, Effects of reservoir connectivity on stream fish assemblages in the Great Plains: Canadian Journal of Fisheries and Aquatic Sciences, v. 63, p. $480-493$.

Horton, R.E., 1932, Drainage-basin characteristics: Transactions American Geophysical Union, v. 13, p. 350-361.

Luttrell, G.R., Echelle, A.A., Fisher, W.L., and Eisenhour, D.J., 1999, Declining status of two species of the Macrhybopsis aestivalis complex (Teleostei: Cyprinidae) in the Arkansas River Basin and related effects of reservoirs as barriers to dispersal: Copeia, v. 1999, no. 4, p. 981-989.

Ottberg, Fabrice, and Blank, Matt, 2015, Solutions to the impacts of roads and other barriers on fish and fish habitat, in van dee Ree, Rodney, Smith, D.J., and Grilo, Clara, eds., Handbook of road ecology: John Wiley \& Sons, p. 364-372.

Perkin, J.S., and Gido, K.B., 2012, Fragmentation alters stream fish community structure in dendritic ecological networks: Ecological Applications, v. 22, p. 2176-2187.

Perkin, J.S., Gido, K.B., Johnson, Eric, and Tabor, V.M., 2010, Consequences of stream fragmentation and climate change for rare Great Plains Fishes: Great Plains Landscape Conservation Cooperative, prepared by Kansas State University, 35 p., accessed February 18, 2014, at https://lccnetwork.org/ project/consequences-stream-fragmentation-and-climatechange-rare-great-plains-fishes.

Poff, N.L., and Ward, J.V., 1989, Implication of streamflow variability and predictability for lotic community structureA regional analysis of streamflow patterns: Canadian Journal of Fisheries and Aquatic Sciences, v. 46, p. 1805-1818.

Schrank, S.J., Guy, C.S., Whiles, M.R., and Brock, B.L., 2001, Influence of instream and landscape-level factors on the distribution of Topeka shiners Notropis topeka in Kansas streams: Copeia, v. 2001, no. 2, p. 413-421.

Warren, M.L., Jr., and Pardew, M.G., 1998, Road crossings as barriers to small-stream fish movement: Transactions of the American Fisheries Society, v. 127, p. 637-644. 


\section{Chapter 11. Data Gaps, Limitations, and Uncertainty}

\section{Data Gaps, Limitations, and Uncertainty}

\section{Overview}

Rapid Ecoregional Assessments (REAs) summarize information at spatial extents that provide a broader context for local management decisions, but they often lack the spatial resolution that provides information on local ecological conditions. Regional datasets also have spatial inaccuracies that limit their usefulness at scales approaching the resolution of the datasets. For example, $30 \times 30$-meter-resolution vegetation maps are best used to summarize vegetation patterns at much larger spatial extents, such as 1 kilometer (0.6 mile) (LANDFIRE, 2012). More detailed information is often available locally that is not available for broad geographic extents, such as ecoregions. In addition, local datasets may be updated more frequently than regional datasets. Although local assessments can have greater accuracy and precision than REA datasets, they may not be at a sufficiently broad extent to capture landscape-level ecological attributes (such as landscape structure) and patterns necessary to evaluate cumulative effects. Because of these limitations, landscape- and local-level data can complement each other, and their limitations can be minimized by using both scales of data for informing planning and management decisions. The use of multiscale data necessitates an understanding of the limitations and assumptions inherent to each dataset scale.

The spatial extent of the datasets ideally covers the full spatial extent of the Southern Great Plains (SGP) to avoid introducing spatial bias created by combining datasets that may vary in methods, accuracy, and completeness. For example, some datasets were only available at a state level (such as water diversions), and differences across state lines may result from differences among source datasets.

REAs synthesize and summarize datasets to assess change agents and their potential effects on species habitats and ecological communities. However, we generally lack data on how most species respond to change agents along an intensity gradient. For example, many species have been documented to avoid high-intensity energy development, but the intensity level or threshold at which a species is no longer negatively affected by energy development is poorly understood for most species and varies among species. Consequently, the potential risks posed by change agents are best viewed along an intensity gradient, with greater confidence in the potential risk from change agents at the highest intensity levels (for example, terrestrial development index [TDI] scores $>35$ percent) and the lowest risks in relatively undeveloped areas (TDI scores $\leq 2$ percent).
In this chapter, we summarize the data gaps, limitations, and uncertainty for source and derived datasets for the Southern Great Plains REA. We also summarize the general themes of management questions identified in the pre-assessment phase of this REA (Assal and others, 2015) that could not be addressed because of data limitations.

\section{Change Agents}

\section{Development}

The surface disturbance footprint used to generate the TDI was compiled from a variety of sources that vary in spatial accuracy (table A-1). Spatial inaccuracies in mapping the development variables (agricultural croplands, urban areas, roads, and energy and minerals) can affect the TDI score. At broad spatial extents, deriving an index from moving windows can minimize the effects of local inaccuracies by averaging the area of the surface disturbance footprint over larger scales (Theobald, 2007). National road datasets (table A-1) often lack the precision, accuracy, and detail of datasets available at smaller spatial extents, such as a digitized road layer developed at the state level (O'Donnell and others, 2014).

The aquatic development index (ADI) uses catchmentscale mapping units from the National Hydrography Dataset Plus, version 2.1 (U.S. Environmental Protection Agency and U.S. Geological Survey, 2012), which is derived from a $30 \times 30$-meter-resolution digital elevation model. In the relatively flat terrain prevalent across much of the Southern Great Plains (SGP), this resolution is insufficient to detect centimeter-scale variations in elevation that can affect hydrologic flow, resulting in poorly delineated catchments and catchments that span the boundaries of adjacent sixth-level watersheds. Improved elevation models (particularly based on lidar [light detection and ranging]) can help to improve catchment definitions. Many fine-scale inaccuracies are minimized by using ADI scores summarized by sixth- and fifth-level watersheds.

There were some limitations for the datasets used as input variables in the ADI (table A-1). Surface and ground diversion datasets were only available at a state level, which can introduce discrepancies across state boundaries. Most state datasets included information on water rights, but the status (for example, licensed, permitted, abandoned) was not consistently available, so we assumed that all water rights were active. Water diversion datasets generally lack information on size or water volumes diverted. Although many state-level datasets include precise location data (such as latitude and longitude coordinates), others are generalized to the Public Land 
Survey System section (in those cases, all diversions were assumed to be located at the center of the section). In addition, the most recent available state-level datasets varied by year (2007-2016) and update frequency.

National-level datasets on the location of dams and road and railroad crossing were used. The datasets used to map the location of dams (table A-1) included dams ranging in storage area from 0 (or unrecorded) to 30,220,260,000 cubic meters $(24,500,000$ acre-feet). Although dam size can affect the degree of flow alteration, dams of any size can alter flow and restrict fish movement. In addition, off-stream dams can reduce overland flows from intermittent drainages. Road and railroad stream crossings also vary in their capacity to reduce fish movement (Ottberg and Blank, 2015). Consequently, we could not factor in the size, degree of flow alteration, or potential for inhibiting fish movement in the ADI. Despite such limitations, we found that the ADI is a relatively good predictor of invertebrate and sensitive fish diversity and can serve as a useful index for identifying relatively undeveloped aquatic systems (Carr and Melcher, 2015).

\section{Fire}

Prior to the 1980s, there was limited availability of regional fire occurrence data. In addition, there is incomplete understanding of historical fire regimes in the SGP because evidence of burning does not persist as long for grasslands and shrublands as it does for forests. The Monitoring Trends in Burn Severity perimeter dataset (table A-1) used for mapping fire occurrence is derived from satellite imagery and may not capture low-severity fires smaller than the minimum mapping unit (405 hectares; 1,000 acres) or burns that have had time to revegetate between the Landsat imaging events used to map burns.

\section{Invasive Species}

Survey data on nonnative and invasive species are lacking for many regions of the SGP. Survey data are often biased by proximity to roads. Because of the limited amount of occurrence data, we mapped potentially altered vegetation by using several LANDFIRE Existing Vegetation Types (EVTs) (table A-5) that may represent a continuum of altered vegetation ranging from highly altered urban landscaping to pasturelands that may be similar in vegetative composition to native grasslands.

Because LANDFIRE EVTs (table A-5) do not accurately map introduced woody riparian species (Carr and Melcher, 2015), we used published occurrence data for these species (Jarnevich and others, 2011; Jarnevich and Reynolds, 2011) to model habitat suitability. Although this published dataset was the best available across the SGP, our modeled thresholds were statistically weak. As a consequence, the models may under- or over-represent suitable habitat for Russian olive and tamarisk. Spot inspection of aerial imagery indicated considerable variation in vegetative cover and potential misclassification of invasive species EVTs.

\section{Climate Change}

Projecting potential changes in temperature and precipitation poses many challenges, and there is considerable uncertainty in the projected results of climate change models. Available global climate models produce a broad range of potential climate scenarios, particularly for precipitation. The likelihood of any specific scenario occurring is unknown. Furthermore, the bioclimatic envelope models used to predict the potential distribution of species for different climate scenarios do not include biotic interactions, the effects of increasing $\mathrm{CO}_{2}$ on evapotranspiration, interactions with other change agents, and other factors that can influence where species may occur. However, evaluating the potential for change in several climate scenarios can help managers to consider areas of the SGP that may be most vulnerable to changing climates and to identify management actions that may enhance system resilience to climate change and other change agents.

\section{Ecological Community Distributions}

\section{Grassland Communities}

We conducted a preliminary review and analysis of the suitability of using existing landcover datasets to map the historical and baseline grassland communities for the REA project area (Reese and others, 2016). Because of the limitations in these datasets, the REA stakeholders suggested using datasets from the Natural Resources Conservation Service (NRCS) to map the potential historical and current distribution of native grasslands for the REA (Callan and others, 2016; Reese and others, 2016). The inaccuracies and spatial resolution of the NRCS datasets may influence the local-level accuracy of the estimated historical grasslands datasets, but the datasets nevertheless provide a basis for evaluating broad-scale changes in grassland distributions.

\section{Riparian Areas and Nonplaya Wetlands}

Available datasets for delineating riparian areas and nonplaya wetlands across the SGP were limited. Data from the National Wetlands Inventory (U.S. Fish and Wildlife Service) varied considerably in wetland density and completeness across state lines. We used LANDFIRE EVTs (table A-5) because they provide more consistency across the SGP, but they also contain many fine-scale errors in vegetation classification, particularly for introduced riparian vegetation. Regionwide information on the historical distribution of aquatic communities was not available for the SGP. 


\section{Playa Wetlands and Saline Lakes}

We used the most comprehensive playa datasets, which were compiled from several different sources (table A-4), but data were not available for Wyoming. Because playas modified by cultivation are generally not mapped, we were unable to distinguish between altered and functional playas. Field verification is the most effective method for establishing playa condition, but few of the roughly 90,000 recorded playas have been surveyed. The perimeters of both playas and saline lakes can vary between years, leading to variation among datasets due to timing of source imagery. In addition, both saline lakes and playa wetlands are sometimes divided by roads and other barriers, making counts potentially inconsistent. Because we were unable to assess hydrological connectivity, we delineated each saline lake divided by anthropogenic barriers as a separate waterbody, which may lead to higher counts compared to the number of named saline lakes.

\section{Prairie Streams and Rivers}

We used the National Hydrography Dataset to map prairie streams and rivers (table A-4). At 1:100,000 (medium) resolution, ephemeral streams were poorly mapped. Consequently, we have likely underestimated the total stream length for the SGP. Although altered flow (both annual flow and instream storage) is a crucial hydrological function, assessing flow alteration was beyond the scope of the REA, which relies on published models (such as Fore and others, 2014) that do not include altered flow. Annual flow was retained and included with the data delivery for possible future use.

\section{Patch Size and Connectivity}

Although landscapes are clearly patchy, defining a patch depends on the species or response variable in question, as well as the scale of analysis (Kotliar and Wiens, 1990). This is partly due to differences among species in their responses to spatial heterogeneity in the environment, which can vary across spatial and temporal scales. Similarly, functional connectivity refers to how landscape structure affects the movement of organisms and depends on a species' response to structural connectivity of its habitat (Wiens, 2002). Although methods for evaluating functional connectivity are available (such as Compton and others, 2007; Beier and others, 2011; Cushman and others, 2013), the short time frame of the REA was not sufficient to develop functional connectivity models for each species.

The REA includes landscape-level analyses that reflect broad-scale structural connectivity. TDI and ADI maps display relatively undeveloped areas, which are assumed to promote organism movements, and relatively developed areas, which may inhibit movements. Patch-size and landscape-level area maps show the size and spatial patterning of patches; larger and clustered patches may facilitate movements. Smaller, dispersed patches may serve as stepping stones to enable movements across otherwise unsuitable areas. Collectively, development, patch size, landscape-level area, and overall landscape-level rank provide indexes of fragmentation and structural connectivity across a range of scales.

\section{Management Questions Not Addressed}

There were several general themes of management questions identified for the Southern Great Plains REA (Assal and others, 2015, table B-1) that could not be addressed because of data gaps or limitations.

\section{Altered Fire Regimes}

- What are the effects of fire on communities and wildlife habitats and forage?

- How have wildlife habitats and communities been degraded (presence of invasive woody species, loss of shinnery oak) because of improper fire management, including lack of fire?

- Where has ecological conversion of communities occurred as a result of fire exclusion?

- Where can prescribed fire be reintroduced to maintain shortgrass prairie?

- Where has erosion increased because of increased fire frequency or intensity?

\section{Shrub Dynamics}

- Where are shinnery oak stands and sand sagebrush altered by herbicide application and inappropriate grazing practices?

- Where does shinnery oak control overlap with the distribution of lesser prairie chicken?

- Where are monotypic stands of shinnery oak outside of the range of natural variation (altered composition of the grassland, forb, and shinnery oak mosaic)?

- Where are nonnative woody shrubs expanding into native shrublands?

- How can we manage eastern redcedar (mostly privately owned), mesquite, and one-seeded juniper (Juniperus monosperma)? 


\section{Terrestrial Development}

- How has development altered air quality?

- How has oil and gas development affected ferruginous hawk nesting?

\section{Aquatic Development}

- How does water withdrawal (including reduced flow, water quality, dewatering, impoundments, and seasonal dynamics) affect aquatic species (freshwater mussels, fish communities, and fish hosts)?

- How does altered flow regime, channelization, and inundation of habitat affect birds (especially the habitat for the interior least tern and its forage fish species and playa lakes for the snowy plover)?

- How does aquatic development affect water quality and salinity changes?

- How are successional changes in lakes and reservoirs (siltation) affecting habitat heterogeneity?

- How are aquatic communities (rivers, streams, riparian areas, nonplaya wetlands, playas, and saline lakes) being affected by water development?

- Where are toxic algae blooms occurring in lakes and reservoirs?

- How is water demand contributing to ecological changes in areas experiencing prolonged drought?

- What are the expected ecological communities after currently irrigated areas are abandoned because of aquifer depletion?

\section{Invasive Species}

- How are invasive species affecting populations and habitats of native species?

- What areas are potentially at risk from invasive species expansion?

- What is the distribution of invasive species?

\section{Conservation Reserve Program}

- What are the most beneficial native seed mixes for wildlife used on Conservation Reserve Program lands?
- What are the potential consequences of removing Conservation Reserve Program lands from the program, especially playa wetlands?

- What Conservation Reserve Program lands have high value for wildlife?

\section{Climate Change}

- What is the phenology of grasslands for changing climates?

- How could flooding or drying projected by climate change scenarios affect playa wetlands (including as habitat for conservation elements)?

- How will climate change affect livestock practices on the landscape?

- How will drought affect conservation elements?

- How will climate change affect water demand, and what are the concomitant effects on conservation elements?

- What are the potential hydrological changes related to and the effects of changing climates?

\section{Poisoning/Herbicides/Pesticides}

- How does poisoning intended for coyotes inadvertently affect swift fox?

- How is the dune sagebrush lizard affected by herbicides?

- How does pesticide use in agricultural croplands affect forage for wildlife?

- How does chemical contamination affect the interior least tern's prey base and burrowing owls?

- How does control of prairie dogs affect ferruginous hawks?

\section{Grazing}

- What are the effects of grazing on shortgrass prairie, riparian areas, sand sagebrush, and shinnery oak?

- How does grazing affect wildlife species (especially the lesser prairie chicken)?

- What are the effects of the loss of native grazing species?

\section{Recreation}

- How are human activities, including recreation, affecting nesting birds? 


\section{References Cited}

Assal, T.J., Melcher, C.P., and Carr, N.B., eds., 2015, Southern Great Plains Rapid Ecoregional AssessmentPre-assessment report: U.S. Geological Survey Open-File Report 2015-1003, 284 p., accessed September 2015 at https://doi.org/10.3133/ofr20151003.

Beier, Paul; Spencer, Wayne; Baldwin, R.F.; and McRae, B.H., 2011, Toward best practices for developing regional connectivity maps: Conservation Biology, v. 25, no. 5, p. 879-892.

Callan, Ramana, Leinwand, I.I.F., Reese, G.C., Assal, T.J., Manier, D.J., Carr, N.B., Burris, Lucy, and Ignizio, D.A., 2016, Estimated historical distribution of grassland communities of the Southern Great Plains: U.S. Geological Survey data release, accessed November 14, 2016, at https://doi.org/10.5066/F71Z42J3.

Carr, N.B., and Melcher, C.P., eds., 2015, Wyoming Basin Rapid Ecoregional Assessment: U.S. Geological Survey Open-File Report 2015-1155, 896 p., accessed September 2015 at https://doi.org/10.3133/ofr20151155.

Compton, B.W., McGarigal, Kevin, Cushman, S.A., and Gamble, L.R., 2007, A resistant-kernel model of connectivity for amphibians that breed in vernal pools: Conservation Biology, v. 21, no. 3, p. 788-799.

Cushman, S.A., Landguth, E.L., and Flather, C.H., 2013, Evaluating population connectivity for species of conservation concern in the American Great Plains: Biodiversity Conservation, v. 22, p. 2583-2605.

Fore, J.D., Sowa, S.P., Galat, D.L., Annis, G.M., Diamond, D.D., and Rewa, Charles, 2014, Riverine threat indices to assess watershed condition and identify primary management capacity of agriculture natural resource management agencies: Environmental Management, v. 53, p. 567-582.

Jarnevich, C.S., Evangelista, Paul, Stohlgren, T.J., and Morisette, Jeffery, 2011, Improving national-scale invasion maps-Tamarisk in the western United States: Western North American Naturalist, v. 71, p. 164-175.
Jarnevich, C.S., and Reynolds, L.V., 2011, Challenges of predicting the potential distribution of a slow-spreading invader-A habitat suitability map for an invasive riparian tree: Biological Invasions, v. 13, p. 153-163.

Kotliar, N.B., and Wiens, J.A., 1990, Multiple scales of patchiness and patch structure- A hierarchical framework for the study of heterogeneity: Oikos, v. 59, p. 253-260.

LANDFIRE, 2012, Existing Vegetation Type (ver. 1.3.0): U.S. Forest Service and U.S. Department of the Interior, accessed December 29, 2014, at https://landfire.gov/ NationalProductDescriptions21.php.

O’Donnell, M.S., Fancher, T.S., Freeman, A.T., Ziegler, A.E., Bowen, Z.H., and Aldridge, C.L., 2014, Large scale Wyoming transportation data-A resource planning tool: U.S. Geological Survey Data Series 821, 21 p., accessed December 8, 2016, at https://doi.org/10.3133/ds821.

Ottberg, Fabrice, and Blank, Matt, 2015, Solutions to the impacts of roads and other barriers on fish and fish habitat, in van dee Ree, Rodney, Smith, D.J., and Grilo, Clara, eds., Handbook of road ecology: John Wiley \& Sons, p. 364-372.

Reese, G.C., Manier, D.J., Carr, N.B., Callan, Ramana, Leinwand, I.I.F., Assal, T.J., Burris, Lucy, and Ignizio, D.A., 2016, Estimated historical distribution of grassland communities of the Southern Great Plains: U.S. Geological Survey Open-File Report 2016-1184, 13 p., accessed December 12, 2016, at https://doi.org/10.3133/ofr20161184.

Theobald, D.M., 2007, GIS concepts and ArcGIS methods: Fort Collins, Colo., Conservation Planning Technologies, $429 \mathrm{p}$.

U.S. Environmental Protection Agency and U.S. Geological Survey, 2012, NHDPlus version 2.1 [vector digital data, raster digital data, tabular digital data]: U.S. Environmental Protection Agency and U.S. Geological Survey, accessed January 25, 2015, at http://www.horizon-systems.com/ NHDPlus/NHDPlusV2_data.php.

Wiens, J.A., 2002, Central concepts and issues of landscape ecology, in Gutzwiller, K.J., ed., Applying landscape ecology in biological conservation: New York, Springer-Verlag, p. 3-21. 



\section{Appendix A. Methodological Details for Derived Datasets}

\section{Introduction}

An overview of the assessment framework for the Southern Great Plains Rapid Ecoregional Assessment (REA) is provided in chapter 2, "Methods Overview." This appendix provides additional details on the methods and source datasets (source datasets are listed in the "Data Sources" section of this appendix). All analyses were performed using ArcGIS ModelBuilder tools or Python scripts (Environmental Systems Research Institute, 2014; Python Software Foundation, 2014). Additional information for REAs, including metadata, as well as geographic information system tools and scripts, are served online at the BLM Landscape Approach Data Portal (https://landscape.blm.gov/geoportal/catalog/main/home.page).

\section{Change Agents}

Four change agents were evaluated for the Southern Great Plains REA: development, fire, invasive species, and climate change (see chapter 2 "Methods Overview"). The source datasets for all change agents are provided in table A-1.

\section{Development}

\section{Terrestrial Development Index}

The terrestrial development index (TDI) uses methods similar to those described in Carr and Melcher (2015) and Carr and others (2017). We quantified the surface disturbance footprint (hereafter referred to as footprint) from development (agricultural croplands, urban areas, roads, railroads, and energy and minerals) by using datasets listed in table $\mathrm{A}-1$. All linear features (roads, railroads, pipelines, utility lines) and points (oil and gas wells, wind turbines) were buffered using the distances in Carr and others (2017). Buffered footprints and polygonal data (solar arrays, mines) were rasterized (converted to a grid) and assigned a value of 1 . The $30 \times 30$-meter $(\mathrm{m})$ footprint was created by summing all component datasets, and the maximum disturbance value of the composite data layer was set at 100 percent. The TDI score was derived by summing the footprint within a 2.5-kilometer-radius (1.6-mile-radius) moving window using the ArcGIS focal neighborhood statistics function (Environmental Systems Research Institute, 2014).

TDI scores range from 0 to 100 percent. For visualization and analysis purposes, we divided the TDI scores into seven classes by using 10 approximately equal subsets of the data. Because a primary objective of the REA is to identify relatively intact areas, we retained the four classes with the lowest scores and combined the remaining classes with the highest scores into three classes (fig. A-1). At 2.5 kilometers (km), TDI scores of $<1$ percent represent areas with very low levels of development (such as a few roads or oil and gas wells). Scores between 1 and 5 percent often represent areas with low to medium development, including low densities of roads or medium densities of oil and gas wells (for example, 4-8 wells per section), whereas TDI scores $>5$ percent represent medium to high levels of development, including large, relatively high-density oil and gas fields, surface mines, agricultural fields, centers of urban development, and major highways (figs. 3-1 and A-1).

\section{Aquatic Development Index}

The aquatic development index (ADI) is modified from similar methods (Annis and others, 2010; Fore and others, 2014; Carr and Melcher, 2015). Table A-2 summarizes the variables and metrics used as indicators for ecological attributes associated with streams and rivers. Table A-1 summarizes the data sources for each variable. Variables and metrics can address more than one ecological attribute (table A-2). For example, structures that alter connectivity (roads, dams, and water diversions) can also alter flow or sedimentation regimes. We used the footprints from the terrestrial development variables to address multiple ecological attributes (table A-2). Stream crossings (roads and railroads), water diversions, and dams were used as indicators of altered flow regimes, sedimentation, and connectivity.

ADI quantifies development at three hydrologically defined scales: (1) local catchment for a given stream segment, (2) upstream contributing area for the local catchment, and (3) the total drainage representing the combined local catchment and the full upstream contributing area (fig. A-2). We included the upstream contributing area for all catchments, including portions of river drainages that extended beyond the SGP boundary (specifically, the upper and lower Missouri River; the Arkansas, Red, and White Rivers; Texas rivers; and the Rio Grande). Catchments, flow lines for perennial and intermittent streams, and processing tools were obtained from the National Hydrography Dataset (NHD) Plus, Version 2.1 (U.S. Environmental Protection Agency and U.S. Geological Survey, 2012). We used the Catchment Attribute Allocation and Accumulation Tool, version 2 (CA3TV2) to aggregate development variables in the total drainage for each local catchment. To obtain upstream values exclusive of the local catchment, we subtracted local catchment values from the total drainage. Development variables for nondraining areas (sinks), which were not addressed by CA3TV2, were also included. Very small catchments less than 3,600 square meters (38,750 square feet) were combined with the adjacent catchment with which they shared the longest boundary. Development variables (counts, lengths, and areas) for local, upstream, and total drainage were converted to densities (number of points, area, or length per catchment area). 
Table A-1. Data sources used to quantify change agents for the Southern Great Plains Rapid Ecoregional Assessment. Variables and data types are provided.

[TIGER, Topologically Integrated Geographic Encoding and Referencing; ACCESS1.0, Australian Community Climate and Earth System Simulator; CESM1(BGC), Community Earth System Model, version 1-Biogeochemistry]

\begin{tabular}{|c|c|c|c|}
\hline $\begin{array}{c}\text { Change } \\
\text { agent }\end{array}$ & Variable & Data type & Data sources $^{1}$ \\
\hline \multirow{9}{*}{ Development } & \multirow[t]{4}{*}{ Energy } & Oil and gas wells & IHS, Inc. (2014) \\
\hline & & Solar arrays & Surface area of solar arrays; Carr and others (2016) \\
\hline & & Wind turbines & Onshore industrial wind turbine locations; Diffendorfer and others (2015) \\
\hline & & Oil and gas pipelines & National Pipeline Mapping System; U.S. Department of Transportation (2014) \\
\hline & Minerals & Surface mines and quarries & Level 3 data; National Gap Analysis Program (2010) \\
\hline & Agriculture & Cultivated croplands & Cultivated crop layer; National Agricultural Statistics Service (2014) \\
\hline & Urban & Urban impervious surface & National Land Cover Database; U.S. Geological Survey (2014) \\
\hline & \multirow[t]{2}{*}{ Water } & Dams & $\begin{array}{l}\text { National Anthropogenic Barrier Dataset; Ostroff and others (2013) } \\
\text { National Inventory of Dams; U.S. Army Corps of Engineers (2015) }\end{array}$ \\
\hline & & $\begin{array}{l}\text { Road and railroad } \\
\text { crossings }\end{array}$ & $\begin{array}{l}\text { TIGER; U.S. Census Bureau (2010) } \\
\text { National Hydrography Dataset Plus; U.S. Environmental Protection Agency } \\
\text { and U.S. Geological Survey (2012) }\end{array}$ \\
\hline Fire & Fire occurrence & Fire polygons & $\begin{array}{l}\text { Monitoring Trends in Burn Severity; U.S. Department of Agriculture and } \\
\text { U.S. Geological Survey (2016) }\end{array}$ \\
\hline \multirow[t]{2}{*}{ Invasive species } & Mesquite & Vegetation types & $\begin{array}{l}\text { Kansas Biological Survey (2016) } \\
\text { LANDFIRE Existing Vegetation Types; LANDFIRE (2012) }\end{array}$ \\
\hline & $\begin{array}{l}\text { Potentially altered } \\
\text { vegetation }\end{array}$ & Land cover types & LANDFIRE Existing Vegetation Types; LANDFIRE (2012) \\
\hline \multirow[t]{4}{*}{ Climate change } & \multirow{3}{*}{$\begin{array}{l}\text { Temperature } \\
\text { and precipitation }\end{array}$} & Historical reference period & Maurer and others (2002) \\
\hline & & Hot and dry scenario & ACCESS1.0; Collier and Uhe (2012) \\
\hline & & Warm and wet scenario & CESM1(BGC); Neale and others (2012) \\
\hline & $\begin{array}{l}\text { Community } \\
\text { distributions }\end{array}$ & $\begin{array}{c}\text { Bioclimatic envelope } \\
\text { vegetation models }\end{array}$ & Rehfeldt and others (2012) \\
\hline
\end{tabular}

${ }^{1}$ Full references for datasets are provided in "Data Sources" section. 

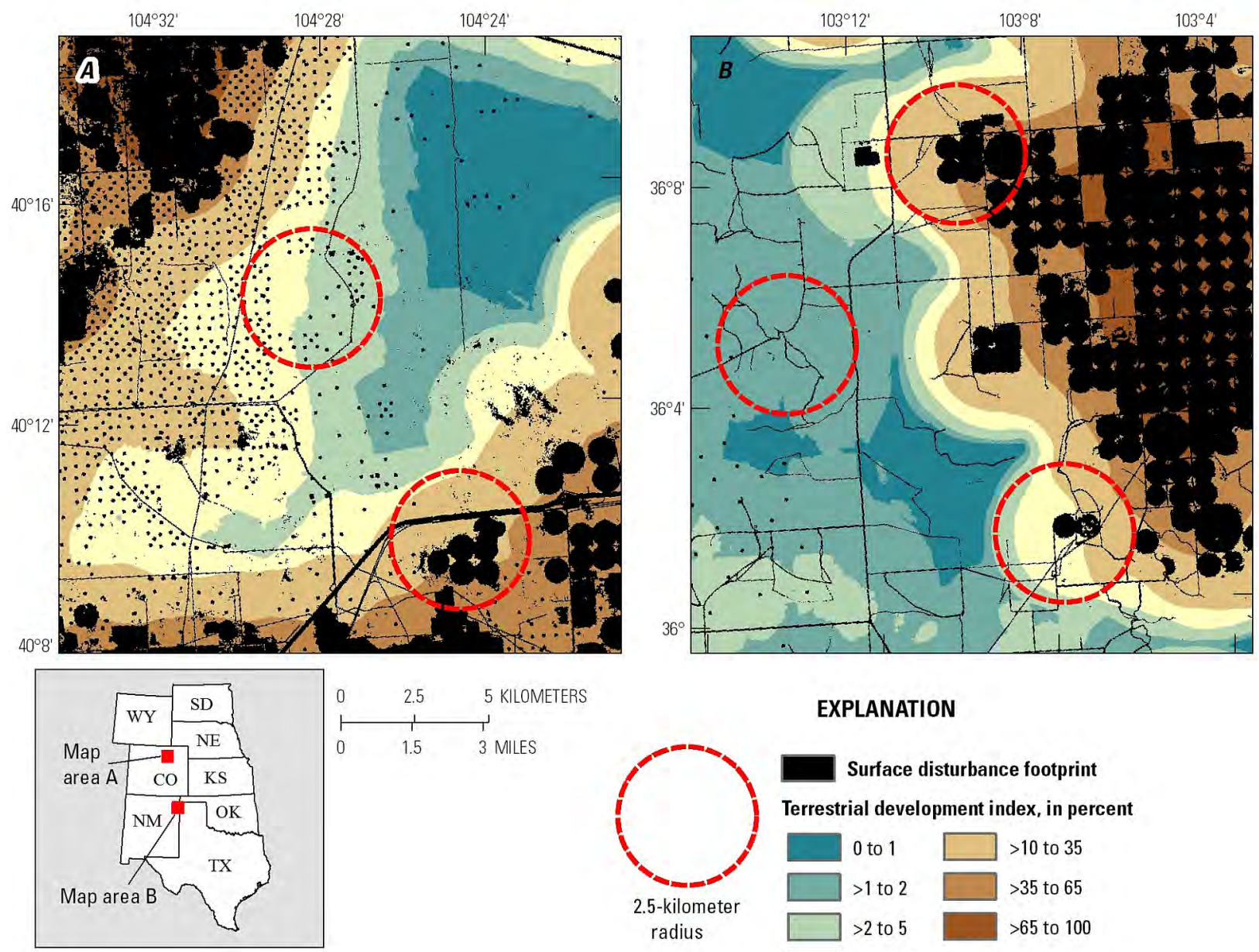

\section{EXPLANATION}

Surface disturbance footprint

Terrestrial development index, in percent

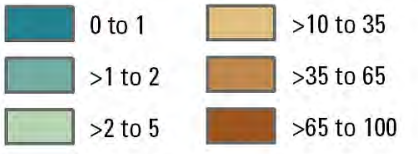

Figure A-1. Terrestrial development index (TDI) score and the contributing footprint from development for two landscapes in the Southern Great Plains. Each location is depicted by a colored square on the inset map. The TDI, derived from the percent of the footprint within a 2.5-kilometer-radius (1.6-mile-radius) moving window (red dashed circles), is depicted. $A, A$ mixed oil and gas field and agricultural landscape in northern Colorado. $B$, The edge of an agricultural landscape in northern New Mexico.

Table A-2. Relations between component variables and metrics for the overall aquatic development index and key ecological attributes for prairie streams and rivers.

$\left[\mathrm{km}^{2}\right.$, square kilometers $]$

\begin{tabular}{|c|c|c|c|c|c|c|}
\hline \multirow[b]{2}{*}{ Variable } & \multirow[b]{2}{*}{ Metric } & \multicolumn{5}{|c|}{ Ecological attribute } \\
\hline & & $\begin{array}{l}\text { Flow } \\
\text { regime }\end{array}$ & $\begin{array}{l}\text { Sedimentation } \\
\text { regime }\end{array}$ & $\begin{array}{l}\text { Riparian } \\
\text { zone }\end{array}$ & $\begin{array}{c}\text { Connec- } \\
\text { tivity }\end{array}$ & $\begin{array}{l}\text { Water } \\
\text { quality }\end{array}$ \\
\hline Surface disturbance & $\begin{array}{l}\text { Variables in the terrestrial development index }\left(\mathrm{km}^{2}\right) \text { per catchment } \\
\text { area }\left(\mathrm{km}^{2}\right)\end{array}$ & $\mathrm{X}$ & $\mathrm{X}$ & $\mathrm{X}$ & & $\mathrm{X}$ \\
\hline Road crossings & Number of road and railroad crossings per catchment area $\left(\mathrm{km}^{2}\right)$ & $\mathrm{X}$ & $\mathrm{X}$ & & $\mathrm{X}$ & \\
\hline Water use & $\begin{array}{l}\text { Number of dams per catchment area }\left(\mathrm{km}^{2}\right) \\
\text { Number of water diversions per catchment area }\left(\mathrm{km}^{2}\right)\end{array}$ & $\begin{array}{l}X \\
X\end{array}$ & $\mathrm{X}$ & $\mathrm{X}$ & $\begin{array}{l}X \\
X\end{array}$ & \\
\hline
\end{tabular}




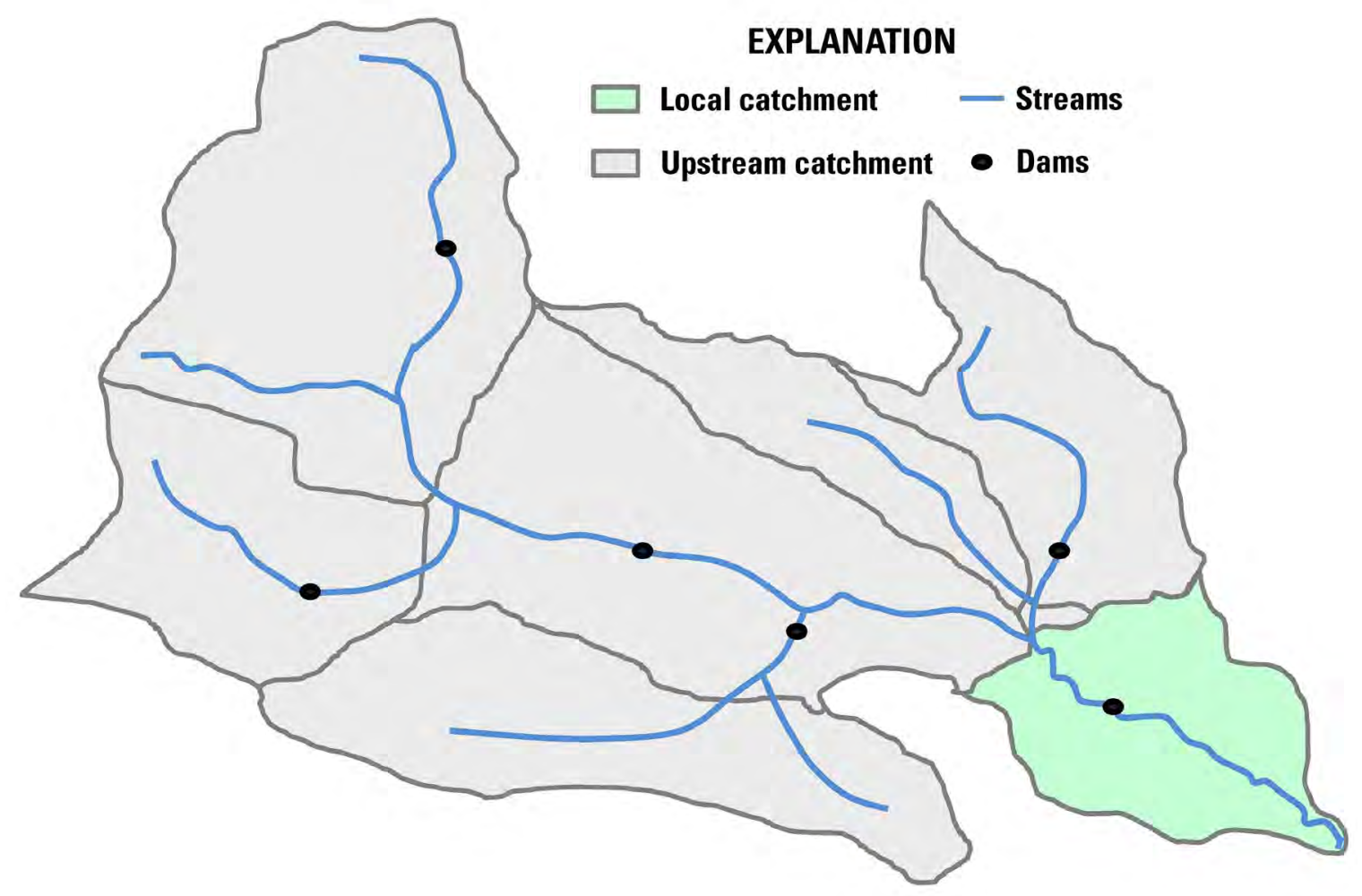

Figure A-2. Diagram of the local and upstream contributing areas for a local catchment. Development variables were summarized for local, upstream, and total drainages, which were used to calculate the local, upstream, and overall aquatic development index.

For each catchment, we calculated local, upstream, and overall ADI. The ADI combines the ranked and scaled variable scores for the development variables in table A-2. We did not weight factors because weighting has limited effects on the ADI score while introducing unnecessary assumptions (Paukert and others, 2011; Fore and others 2014). The local ADI was derived from the local catchment densities, whereas upstream ADI was derived from upstream contributing area densities (exclusive of the local contribution). The overall ADI by catchment was derived by using the total drainage densities for each catchment. The density values for each variable were ranked and rescaled from 0 to 100, derived from a script written in R (R Core Team, 2016). The ranked and rescaled variables were summed by catchment and normalized from 0 to 100 at each scale, representing local ADI, upstream ADI, and overall ADI (figs. A-3, 3-5A, A-4). The catchment-level ADI scores were aggregated by sixthlevel watershed (fig. 3-5B) for core management questions and by fifth-level watershed for integrated management questions.

\section{Invasive Species}

\section{Honey Mesquite and Eastern Redcedar}

We compiled occurrence data for mesquite and eastern redcedar (table A-1) and mapped occurrences by sixth-level watersheds (fig. 4-7). To map potential mesquite occurrence, we summarized the percent of cells $(30 \times 30-\mathrm{m}$ resolution $)$ in each watershed containing the LANDFIRE Existing Vegetation Type (EVT) that indicates the presence of mesquite (table A-5). To map eastern redcedar, we included all watersheds with eastern redcedar occurrences. We also included watersheds containing cells with $>1$ percent cover of honey mesquite and (or) eastern redcedar by using data from the Kansas Biological Survey (table A-1).

\section{Russian Olive and Tamarisk}

We used the same approach to model Russian olive and tamarisk habitat suitability as was used for the Wyoming Basin REA (Carr and Melcher, 2015) and the western United States (Jarnevich and others, 2011, Jarnevich and Reynolds, 2011, Morisette and others, 2013).

The nine bioclimatic variables and distance to water used for the distribution models, and the percent contribution to the model for each variable, are listed in table A-3. Bioclimatic variables were derived following O'Donnell and Ignizio (2012) by using Parameter-elevation Regressions on Independent Slopes Model (PRISM) climate averages for 1980-2009. To identify the threshold for classifying suitable habitat conditions, we identified sixth-level watersheds that contained either Russian olive or tamarisk, and the thresholds were established where the distribution departed from uniform; a probability threshold of 0.0862 was used for Russian olive and 0.25 for tamarisk (figs. 8-6 and 8-7). 

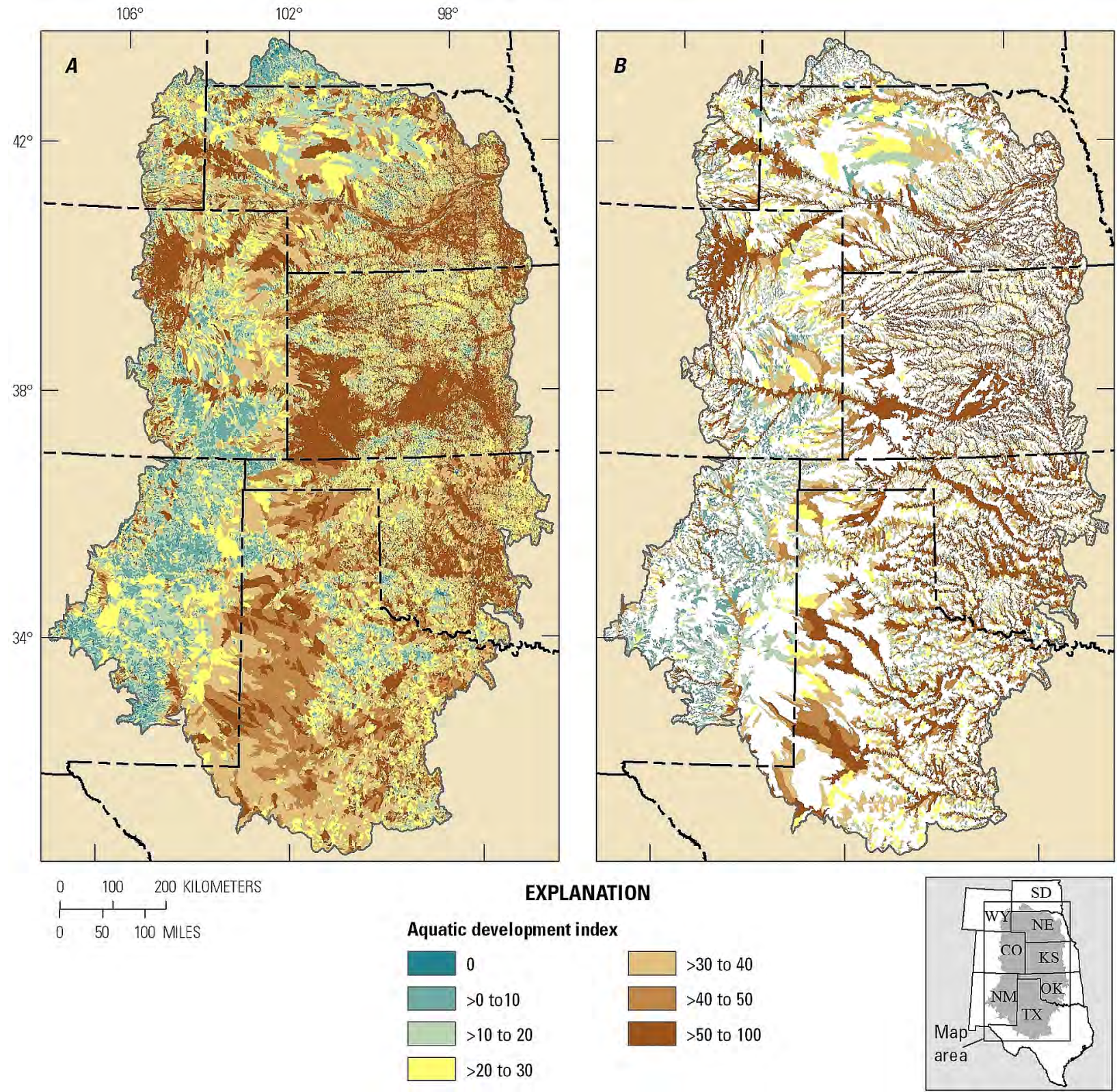

Figure A-3. Components of the aquatic development index (ADI) for the Southern Great Plains, summarized by catchment. $A$, Local ADI. B, Upstream ADI. 

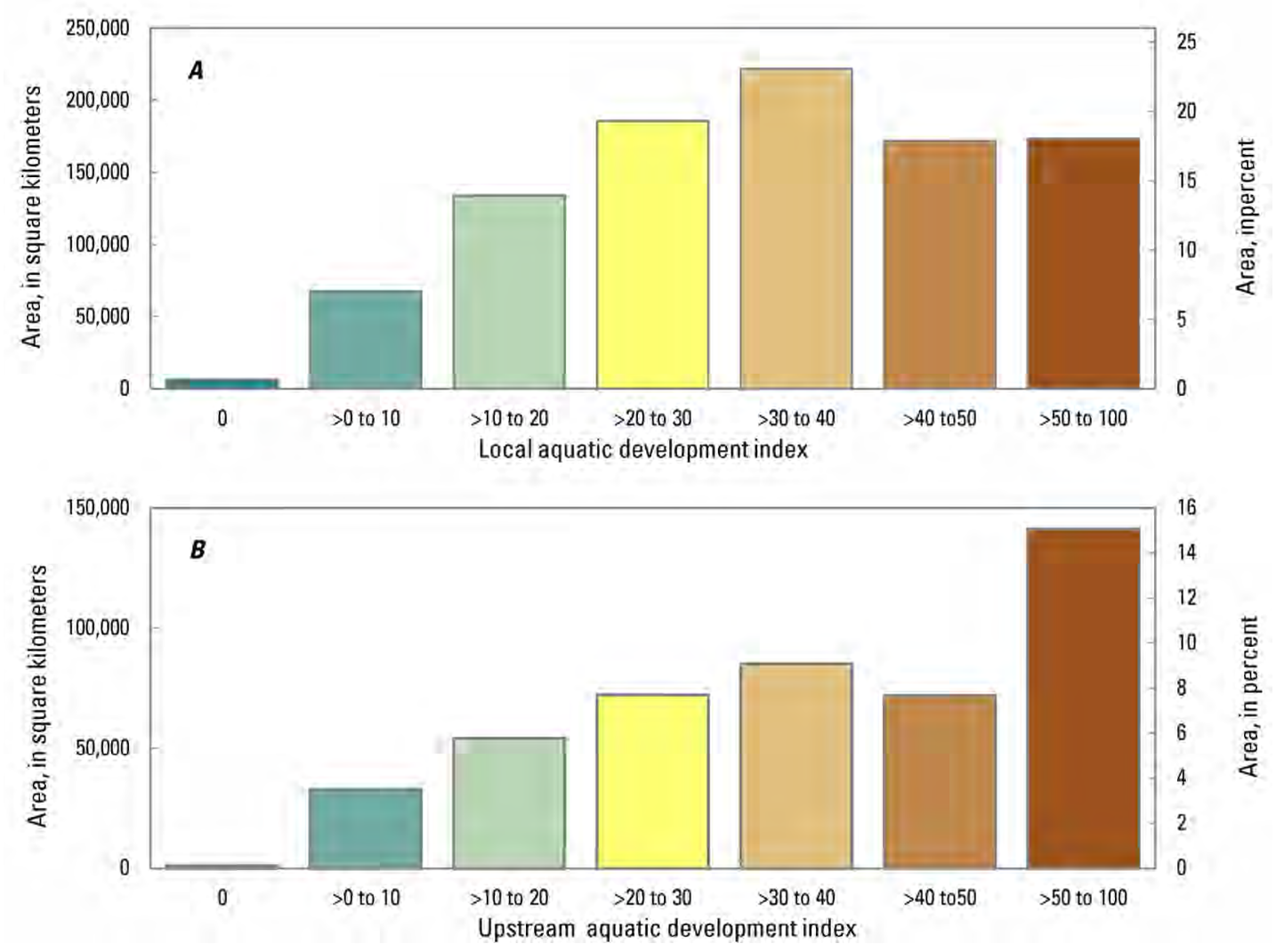

Figure A-4. Total area in aquatic development index (ADI) classes in the Southern Great Plains. A, Local $A D I$. $B$, Upstream ADI. The area of upstream catchments summarized in panel $B$ covers 50 percent of the Southern Great Plains (see fig. A-3B).

\section{Ecological Communities}

\section{Terrestrial Community Baseline Distribution Mapping}

The estimated historical grasslands map (Callan and others, 2016; Reese and others, 2016), which compiled data from the Natural Resources Conservation Service (2015) and LANDFIRE Biophysical Settings (BpS) (LANDFIRE, 2010), was used as the foundation for mapping baseline grassland communities. Ordered processing steps for mapping current vegetation and baseline grassland distributions are included in the metadata associated with the Current Vegetation and Land Cover of the Southern Great Plains raster. We replaced the historical "shrubland, woodland, and forest" class with LANDFIRE EVT (table A-5) except those areas currently classified as ruderal, pastureland, developed, urban vegetation, or invasive herbaceous vegetation (fig. 3-10), where we retained the estimated historical class. To account for grasslands converted by development (for example, figs. 5-1, 6-1, 7-1), we overlaid the development footprint (see the "Terrestrial Development Index" section). Based on the development footprint, approximately 43 percent of historical grasslands has been converted. We also overlaid riparian and wetlands (fig. 8-1), open water, and "shrubland, woodland, and forest" (fig. 1-3) based on LANDFIRE EVT (table A-5) as well as other aquatic communities (figs. 9-1, 9-2, 10-1). Areas where the estimated historical distribution of "shrubland, woodland, and forest" is currently classified as grassland by LANDFIRE EVT were reclassified using the cover types listed in table A-5.

\section{Aquatic Community Baseline Distribution Mapping}

To map the distribution of riparian areas and nonplaya wetlands, we compiled LANDFIRE EVTs and the estimated historical distribution indicating mesic soils and riparian areas (Callan and others, 2016; Reese and others, 2016). Collectively, the two datasets best captured riparian areas and nonplaya wetlands visible in aerial imagery. We classified EVTs corresponding to bottomland, floodplain, marsh, meadow, ravine, riparian areas, swamp, or wetlands to map riparian and wetland areas as indicated in table A-5. Any areas coincident with playas, saline lakes, or the agricultural footprint were not included as riparian areas or nonplaya wetlands. For additional details see previous section.

We used the datasets in table A-4 to map the distribution of playa wetlands and saline lakes. Data from Texas Ecological Mapping Systems (Texas Parks and Wildlife Department, 2014) were used to map playas in Reagan and Upton Counties in south Texas. Published maps (Reeves and Reeves, 1996; Andrei and others, 2006) were used for name 
attribution and verification of saline lakes. Any playa wetlands intersecting saline lakes were excluded from the final playa wetland dataset. Playa wetland data were not available in Wyoming, so that area was excluded from analysis.

The baseline distributions of prairie streams and rivers were derived from NHD flow lines (table A-4) and partitioned by intermittent and perennial hydroperiods. Intermittent streams were mapped by using intermittent and ephemeral flow lines. A preliminary perennial streams dataset was created from all flow lines with perennial or unassigned hydroperiod values. Connector and artificial path flow lines intersecting perennial streams were merged with the preliminary perennial streams. Pipelines, canals, and conduits were excluded from the stream datasets.

\section{Landscape Structure}

\section{Patch Size}

We summarized the area by patch size class (or stream fragment length) for all ecological communities for baseline and relatively undeveloped conditions. For all communities except prairie streams, we used the RegionGroup tool in ArcGIS (Environmental Systems Research Institute, 2014) with tool parameters of eight neighboring cells that used a search radius for cells of the same value. For prairie streams, we derived stream-segment length of perennial streams by using stream partitioning as indicated by the presence of dams.

Appendix A-3. Variables used in the Russian olive and tamarisk distribution models, including values for their percent contribution to the model based on climate data for 1980-2009.

[max temp, maximum temperature; $\min$ temp, minimum temperature]

\begin{tabular}{|c|c|c|}
\hline Model variables & \multicolumn{2}{|c|}{ Percent contribution to the model ${ }^{1}$} \\
\hline Temperature seasonality & 3.991 & 4.841 \\
\hline Minimum temperature of coldest month & 34.334 & 38.378 \\
\hline Mean temperature of wettest quarter & 9.325 & 7.366 \\
\hline Precipitation seasonality (coefficient of variation) & Not applicable & 0.109 \\
\hline Precipitation of warmest quarter & 5.347 & 13.244 \\
\hline Precipitation of coldest quarter & 1.292 & 0.037 \\
\hline Distance to water & 3.864 & 3.085 \\
\hline
\end{tabular}

${ }^{1}$ Calculated by permuting the values at presence and background locations and calculating the change in the area under a receiver operating characteristic curve.

Appendix A-4. Data sources used to map the distribution of baseline ecological communities for the Southern Great Plains Rapid Ecoregional Assessment.

[NHD, National Hydrology Dataset]

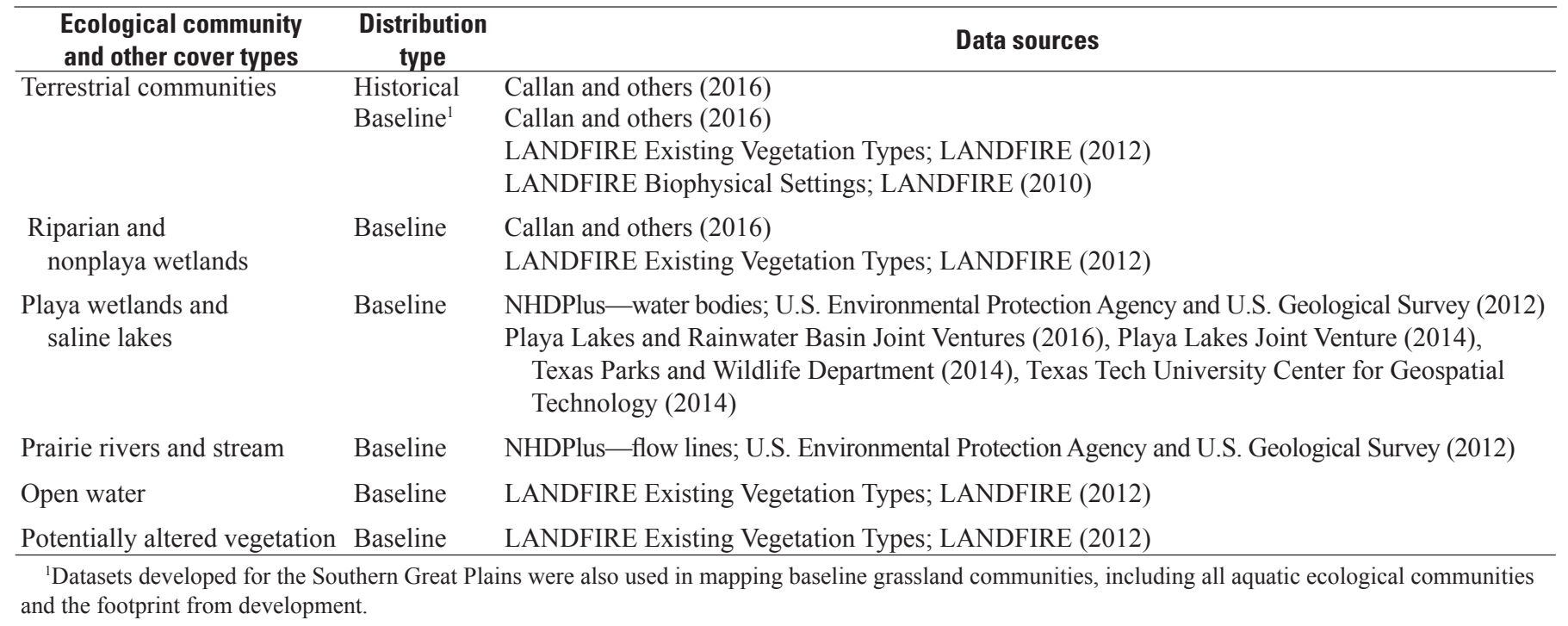


Dams within $30 \mathrm{~m}$ of a perennial stream were defined as creating a flow discontinuity. Fragment lengths were summarized by stream-segment classes for baseline and relatively undeveloped conditions.

\section{Landscape-Level Area Ranking Breakpoints: Calculating Equal Subsets of the Data}

The methods for summarizing overall landscape-level ranks are described in chapter 2. Here we provide additional details on how ranking breakpoints (hereafter referred to as breakpoints) for landscape-level area were determined. The distribution of percentages of the 5-km-radius moving window occupied by each community type was used to select the landscape-level area breakpoints for grassland communities. The distribution of percentages of fifth-level watersheds occupied by each community type was used to select the landscape-level area breakpoints for riparian areas and nonplaya wetlands and for playas and saline lakes. To prevent strongly skewed distributions of percentages from excessive influence on the breakpoints in aquatic communities, we tested for skewness by determining if the observed distribution deviated from an expected exponential distribution, in which case we established a skew threshold. We then partitioned the values above the threshold into three equal subsets of the data (terciles) by using ascending sorted values derived from the Numpy library "percentile" function (Jones and others, 2001; SciPy, 2014). Values below the skew threshold were assigned to the lowest ranked subset.

Landscape-level density for prairie streams and rivers was determined by combining perennial and intermittent stream length in each fifth-level watershed containing either or both stream types. The density was calculated as the total stream length divided by watershed area for each watershed. To minimize the effects of mapping errors, any watersheds with less than $30 \mathrm{~m}$ (98.4 feet) of aggregated stream length were mapped as "below threshold" and excluded. The remaining stream densities were sorted and partitioned into three equal subsets using ascending order sorted values derived from the Numpy library "percentile" function (Jones and others, 2001; SciPy, 2014).

Appendix A-5. Cover types classified from LANDFIRE Existing Vegetation Types (EVTs) for the Southern Great Plains Rapid Ecoregional Assessment. The cover types were used in conjunction with the estimated historical grassland distribution (Callan and others, 2016) to map baseline grassland communities, baseline riparian and nonplaya wetlands, open water, and potentially altered vegetation (table $\mathrm{A}-4)$.

[Existing Vegetation Types from LANDFIRE (2016)]

\begin{tabular}{|c|c|c|}
\hline Cover type $^{1}$ & $\begin{array}{l}\text { LANDFIRE } \\
\text { identifier }\end{array}$ & $\begin{array}{c}\text { LANDFIRE } \\
\text { Existing Vegetation Type }\end{array}$ \\
\hline Sand prairie & $\begin{array}{l}3148 \\
3212 \\
3093 \\
3094 \\
3209\end{array}$ & $\begin{array}{l}\text { Western Great Plains Sand Prairie Grassland } \\
\text { Western Great Plains Sandhill Grassland } \\
\text { Southern Colorado Plateau Sand Shrubland } \\
\text { Western Great Plains Sandhill Shrubland } \\
\text { Western Great Plains Sand Prairie Shrubland }\end{array}$ \\
\hline Tallgrass prairie & $\begin{array}{l}3150 \\
3412 \\
3421 \\
3423\end{array}$ & $\begin{array}{l}\text { Western Great Plains Tallgrass Prairie } \\
\text { North-Central Interior Sand and Gravel Tallgrass Prairie } \\
\text { Central Tallgrass Prairie } \\
\text { Southeastern Great Plains Tallgrass Prairie }\end{array}$ \\
\hline
\end{tabular}


Appendix A-5. Cover types classified from LANDFIRE Existing Vegetation Types (EVTs) for the Southern Great Plains Rapid Ecoregional Assessment. The cover types were used in conjunction with the estimated historical grassland distribution (Callan and others, 2016) to map baseline grassland communities, baseline riparian and nonplaya wetlands, open water, and potentially altered vegetation (table $\mathrm{A}-4$ ).-Continued

[Existing Vegetation Types from LANDFIRE (2016)]

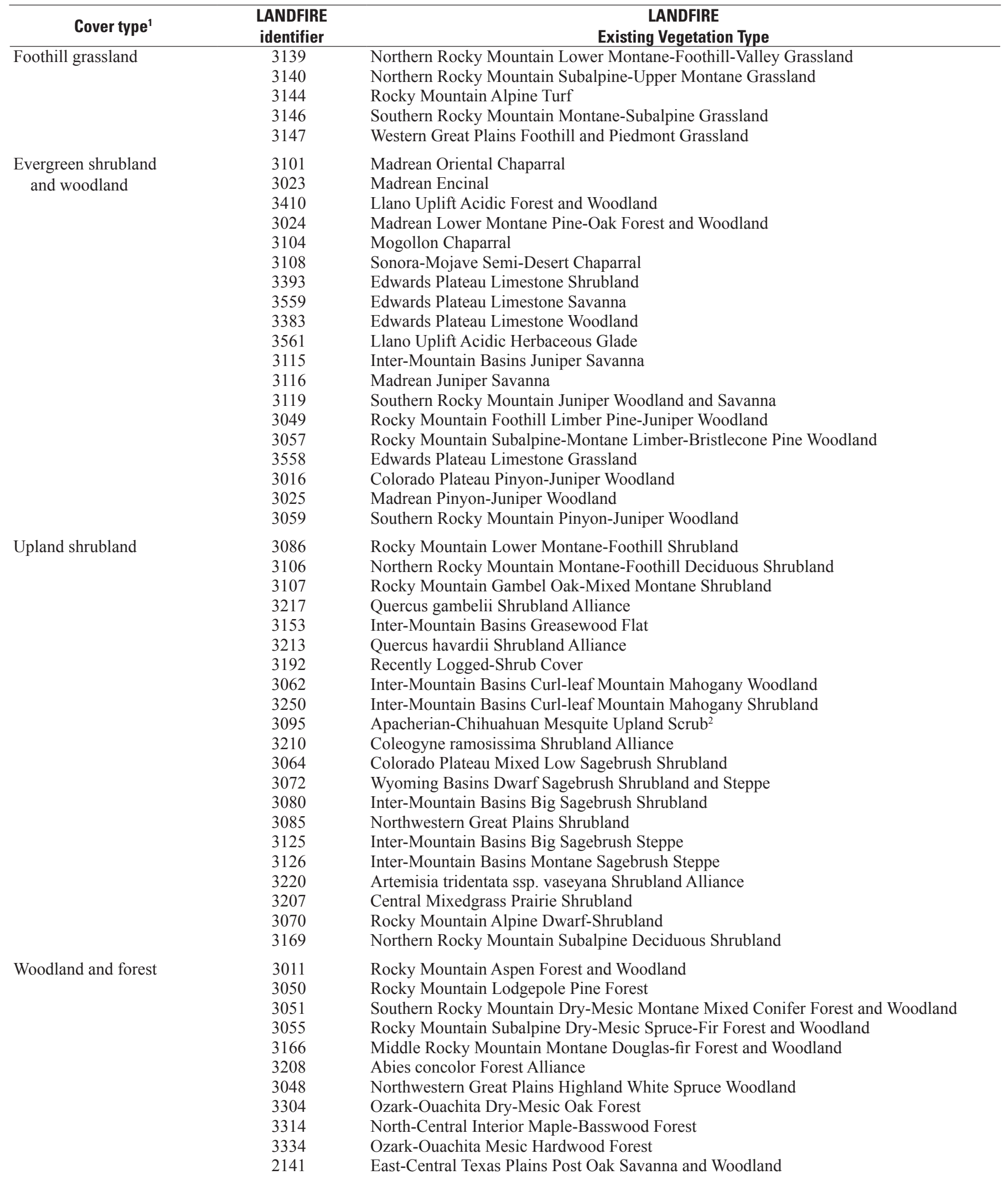


Appendix A-5. Cover types classified from LANDFIRE Existing Vegetation Types (EVTs) for the Southern Great Plains Rapid Ecoregional Assessment. The cover types were used in conjunction with the estimated historical grassland distribution (Callan and others, 2016) to map baseline grassland communities, baseline riparian and nonplaya wetlands, open water, and potentially altered vegetation (table $\mathrm{A}-4)$. - Continued

[Existing Vegetation Types from LANDFIRE (2016)]

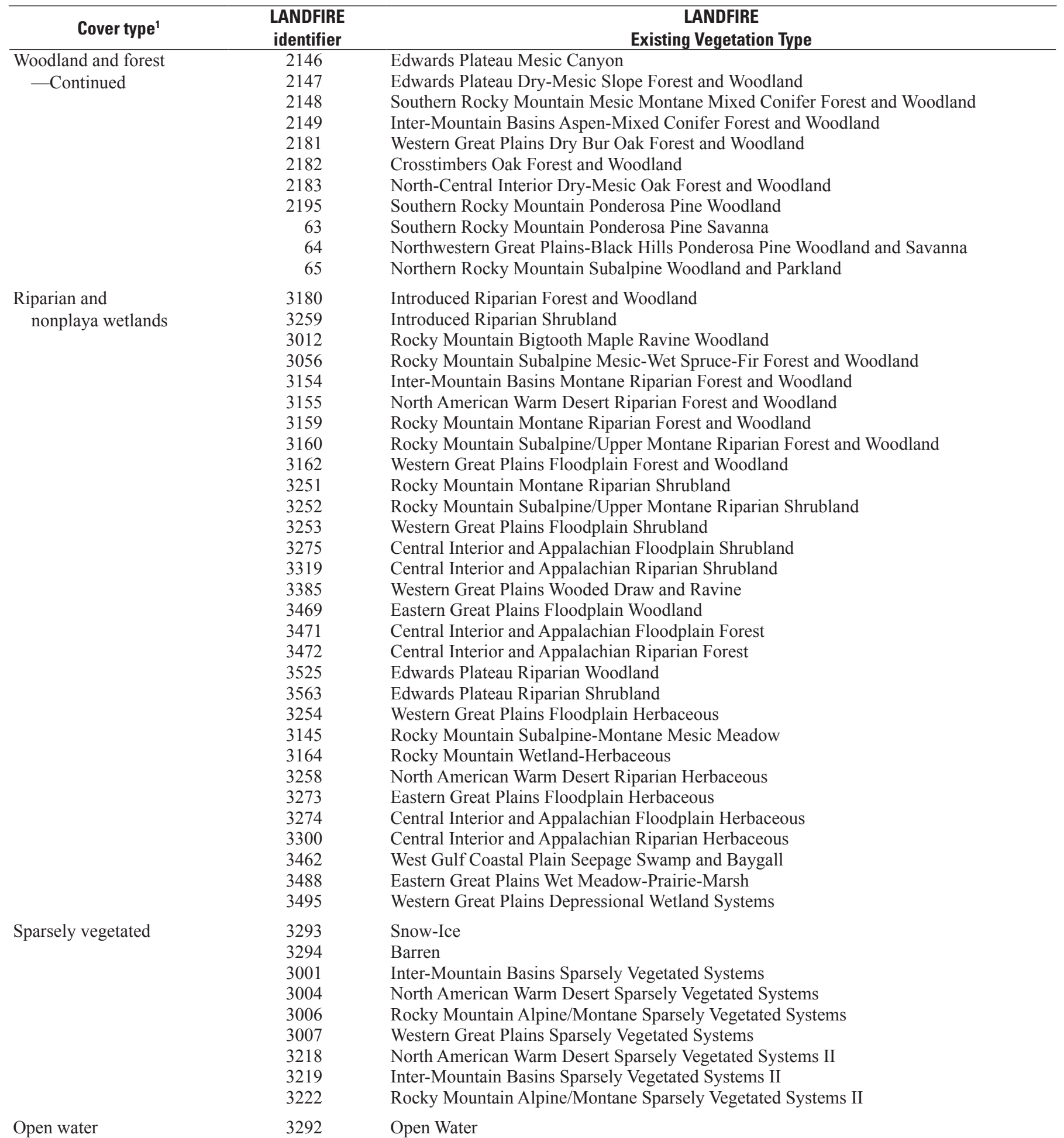


Appendix A-5. Cover types classified from LANDFIRE Existing Vegetation Types (EVTs) for the Southern Great Plains Rapid Ecoregional Assessment. The cover types were used in conjunction with the estimated historical grassland distribution (Callan and others, 2016) to map baseline grassland communities, baseline riparian and nonplaya wetlands, open water, and potentially altered vegetation (table $\mathrm{A}-4)$. - Continued

[Existing Vegetation Types from LANDFIRE (2016)]

\begin{tabular}{|c|c|c|}
\hline Cover type $^{1}$ & $\begin{array}{l}\text { LANDFIRE } \\
\text { identifier }\end{array}$ & $\begin{array}{c}\text { LANDFIRE } \\
\text { Existing Vegetation Type }\end{array}$ \\
\hline & 3529 & Ruderal Upland Herbaceous \\
\hline & 3532 & Ruderal Forest-Northern and Central Hardwood and Conifer \\
\hline & 3533 & Ruderal Forest-Southeast Hardwood and Conifer \\
\hline & 3945 & Western Warm Temperate Undeveloped Ruderal Deciduous Forest \\
\hline & 3948 & Western Warm Temperate Undeveloped Ruderal Shrubland \\
\hline & 3949 & Western Warm Temperate Undeveloped Ruderal Grassland \\
\hline & 3950 & Eastern Cool Temperate Undeveloped Ruderal Deciduous Forest \\
\hline & 3951 & Eastern Cool Temperate Undeveloped Ruderal Evergreen Forest \\
\hline & 3952 & Eastern Cool Temperate Undeveloped Ruderal Mixed Forest \\
\hline & 3953 & Eastern Cool Temperate Undeveloped Ruderal Shrubland \\
\hline & 3564 & Modified/Managed Southern Tallgrass Shrubland \\
\hline & 3967 & Western Cool Temperate Pasture and Hayland \\
\hline & 3987 & Western Warm Temperate Pasture and Hayland \\
\hline \multirow[t]{9}{*}{ Urban vegetation } & 3296 & Low-intensity Development \\
\hline & 3905 & Eastern Cool Temperate Urban Deciduous Forest \\
\hline & 3900 & Western Cool Temperate Urban Deciduous Forest \\
\hline & 3901 & Western Cool Temperate Urban Evergreen Forest \\
\hline & 3902 & Western Cool Temperate Urban Mixed Forest \\
\hline & 3910 & Western Warm Temperate Urban Deciduous Forest \\
\hline & 3911 & Western Warm Temperate Urban Evergreen Forest \\
\hline & 3912 & Western Warm Temperate Urban Mixed Forest \\
\hline & 3906 & Eastern Cool Temperate Urban Evergreen Forest \\
\hline \multirow{2}{*}{ Invasive herbaceous plants } & 3181 & Introduced Upland Vegetation-Annual Grassland \\
\hline & 3183 & Introduced Upland Vegetation-Annual and Biennial Forbland \\
\hline
\end{tabular}

${ }^{1}$ LANDFIRE EVTs classified as invasive herbaceous plants, urban vegetation, pastureland, and ruderal cover types were used to map potentially altered vegetation (fig. 3-10).

${ }^{2}$ Used to map potential for mesquite expansion in fig. 4-7. 


\section{Disclaimers}

Maps provided within this document are not for navigational use.

\section{References Cited}

Andrei, A.E., Smith, L.M., Haukos, D.A., and Surles, J.G., 2006, Community composition and migration chronology of shorebirds using the saline lakes of the Southern Great Plains, USA: Journal of Field Ornithology, v. 77, no. 4, p. $372-383$.

Annis, G.M., Sowa, S.P., Diamond, D.D., Combes, M.D., Doisy, K.E., Garringer, A.J., and Hanberry, Phillip, 2010, Developing synoptic human threat indices for assessing the ecological integrity of freshwater ecosystems in EPA Region 7, final report: Columbia, Mo., University of Missouri, School of Natural Resources, 192 p.

Carr, N.B., and Melcher, C.P., eds., 2015, Wyoming Basin Rapid Ecoregional Assessment: U.S. Geological Survey Open-File Report 2015-1155, 896 p., accessed September 2015 at https://doi.org/10.3133/ofr20151155.

Cushman, S.A., Landguth, E.L., and Flather, C.H., 2013, Evaluating population connectivity for species of conservation concern in the American Great Plains: Biodiversity and Conservation, v. 22, p. 2583-2605.

Environmental Systems Research Institute, 2014, ArcGIS Desktop-Release 10.3: Redlands, Calif., Environmental Systems Research Institute.

Fore, J.D., Sowa, S.P., Galat, D.L., Annis, G.M., Diamond, D.D., and Rewa, Charles, 2014, Riverine threat indices to assess watershed condition and identify primary management capacity of agriculture natural resource management agencies: Environmental Management, v. 53, p. 567-582.

Jarnevich, C.S., Evangelista, Paul, Stohlgren, T.J., and Morisette, Jeffery, 2011, Improving national-scale invasion maps-Tamarisk in the western United States: Western North American Naturalist, v. 71, p. 164-175.

Jarnevich, C.S., and Reynolds, L.V., 2011, Challenges of predicting the potential distribution of a slow-spreading invader-A habitat suitability map for an invasive riparian tree: Biological Invasions, v. 13, p. 153-163.

Jones, Eric; Oliphant, Travis; Peterson, Pearu; and others, 2001, SciPy - Open source scientific tools for Python: SciPy, accessed December 16, 2015, at http://www.scipy.org/.

Morisette, J.T.; Jarnevich, C.S.; Holcombe, T.R.; Talbert, C.B.; Ignizio, Drew; Talbert, M.K.; Silva, Claudio; Koop, David; Swanson, Alan; and Young, N.E., 2013, VisTrails SAHMVisualization and workflow management for species habitat modeling: Ecography, v. 36, p. 129-135.
O'Donnell, M.S., and Ignizio, D.A., 2012, Bioclimatic predictors for supporting ecological applications in the conterminous United States: U.S. Geological Survey Data Series 691, accessed April 3, 2012, at http://pubs.usgs.gov/ds/691/.

Paukert, C.P., Pitts, K.L., Whittier, J.B., and Olden, J.D., 2011, Development and assessment of a landscape-scale ecological threat index for the lower Colorado River Basin: Ecological Indicators, v. 11, no. 2, p. 304-310.

Python Software Foundation, 2014, The Python language reference [for ver. 2.7]: Python Software Foundation, accessed December 2014 at http://www.python.org.

R Core Team, 2016, R-A language and environment for statistical computing: Vienna, Austria, R Foundation for Statistical Computing, accessed January 2016 at https://www.R-project.org/.

Reeves, C.C., and Reeves, J.A., 1996, The Ogallala aquifer of the southern High Plains—v. 1, Geology: Lubbock, Tex., Estacado Books, $360 \mathrm{p}$.

SciPy, 2014, SciPy — Open source scientific tools for Python (ver. SciPy-0.14.0): SciPy, accessed December 13, 2015, at http://www.scipy.org/doc/scipy-0.14.0/reference/ release.0.7.2.html.

\section{Data Sources}

Callan, Ramana, Leinwand, I.I.F., Reese, G.C., Assal, T.J., Manier, D.J., Carr, N.B., Burris, Lucy, and Ignizio, D.A., 2016, Estimated historical distribution of grassland communities of the Southern Great Plains: U.S. Geological Survey data release, accessed November 14, 2016, at https://doi.org/10.5066/F71Z42J3.

Carr, N.B., Fancher, Tammy, Freeman, A.T, and Battles Manley, Heather, 2016, Surface area of solar arrays in the conterminous United States: U.S. Geological Survey data release, accessed June 6, 2016, at https://doi.org/10.5066/ F79S1P57.

Carr, N.B., Leinwand I.I.F., and Wood, D.J.A., 2017, A multiscale index of landscape intactness for management of public lands, chap. 5 of Carter, S.K., Carr, N.B., Miller, K.H, and Wood, D.J.A., eds., Multiscale guidance and tools for implementing a landscape approach to resource management in the Bureau of Land Management: U.S. Geological Survey Open-File Report 2016-1207, p. 55-74, accessed January 2017 at https://doi.org/10.3133/ofr20161207.

Collier, Mark, and Uhe, Peter, 2012, CMIP5 datasets from the ACCESS1.0 and ACCESS1.3 coupled climate models: Centre for Australian Weather and Climate Research Technical Report No. 059, 25 p. 
Colorado Division of Water Resources, 2016a, Final permitsDesignated basins [shapefile]: Colorado's Decision Support Systems, accessed April 18, 2016, at http://cdss.state.co.us/ GIS/Pages/DataByCategory.aspx.

Colorado Division of Water Resources, 2016b, StructuresWith water rights [shapefile]: Colorado's Decision Support Systems, accessed April 18, 2016, at http://cdss.state.co.us/ GIS/Pages/DataByCategory.aspx.

Diffendorfer, J.E.; Compton, Roger; Kramer, Louisa; Ancona, Zach; and Norton, Donna, 2015, Onshore industrial wind turbine locations for the United States through July 2013 (ver. 1.1, May 2015): U.S. Geological Survey Data Series 817, accessed December 21, 2015, at https://doi.org/10.3133/ds817.

Global Biodiversity Information Facility, 2016, Juniperus virginiana L.: Global Biodiversity Information Facility web page, accessed October 5, 2016, at https://demo.gbif.org/ species/2684391.

Greenwood Mapping, 2007, Irrigation points of diversion for Wyoming at 1:24,000 [shapefile]: Wyoming Water Development Commission, prepared by Greenwood Mapping and WWC Engineering, accessed April 19, 2016, at https://www.sciencebase.gov/catalog/ item/4f4e4799e4b07f02db48fa7d.

IHS, Inc., 2014, Production unallocated database: Englewood, Colo., IHS, Inc., accessed January 16, 2015, at https://www.ihs. $\mathrm{com} /$ products/oil-gas-tools-enerdeq-browser.html.

Kansas Biological Survey, [2016], Kansas Biological Survey metadata catalog [percent conifer and mesquite encroachment into lpc habitats]: Kansas Biological Survey, University of Kansas database, accessed October 18, 2016, at http://kars.ku.edu/geonetwork/srv/en/main.home.

Kansas Geological Survey, 2016a, Water Information Management and Analysis System (WIMAS) for the web [active and vested rights within -95.7 to 102 degrees west longitude and 37 to 40 degrees north latitude]: Kansas Geological Survey database, accessed April 18, 2016, at http://hercules.kgs.ku.edu/ geohydro/wimas/query_setup.cfm.

Kansas Geological Survey, 2016b, Water well completion records (WWC5) database: Kansas Geological Survey, accessed April 18, 2016, at http://www.kgs.ku.edu/ Magellan/WaterWell/index.html.

LANDFIRE, 2010, Biophysical Settings (ver. 1.3.0): U.S. Forest Service and U.S. Department of the Interior, accessed May 6, 2015, at https://landfire.gov/ NationalProductDescriptions20.php.

LANDFIRE, 2012, Existing Vegetation Type (ver. 1.3.0): U.S. Forest Service and U.S. Department of the Interior, accessed December 29, 2014, at https://landfire.gov/ NationalProductDescriptions21.php.
LANDFIRE, 2016, LANDFIRE/GAP land cover map unit descriptions: U.S. Forest Service and U.S. Geological Survey, 1,377 p., accessed March 22, 2017, at https://landfire.gov/ documents/LF-GAPMapUnitDescriptions.pdf.

Maurer, E.P., Wood, A.W., Adam, J.C., Lettenmaier, D.P., and Nijssen, B., 2002, A long-term hydrologically based dataset of land surface fluxes and states for the conterminous United States: Journal of Climate, v. 15, no. 22, p. 3237-3251.

National Agricultural Statistics Service, 2014, CropScape and cropland data layer-2013 cultivated layer: U.S. Department of Agriculture National Agricultural Statistics Service dataset, accessed November 26, 2014, at https://www.nass.usda.gov/ Research_and_Science/Cropland/Release/index.php.

National Gap Analysis Program, 2010, National Land Cover Dataset: U.S. Geological Survey, accessed February 5, 2016, at http://gapanalysis.usgs.gov/gaplandcover/data/ download/.

Natural Resources Conservation Service, 2015, Ecological Site Inventory System: U.S. Department of Agriculture Natural Resources Conservation Service data repository, accessed July 2015 at https://esis.sc.egov.usda.gov.

Neale, R.B.; Chen, Chih-Chieh; Gettelman, Andrew; Lauritzen, P.H.; Park, Sungsu; Williamson, D.L.; Conley, A.J.; Garcia, Rolando; Kinnison, Doug; Lamarque, JeanFrancois; Marsh, Dan; Mills, Mike; Smith, A.K.; Tilmes, Simone; Vitt, Francis; Morrison, Hugh; Cameron-Smith, Philip; Collins, W.D.; Iacono, M.J.; Easter, R.C.; Ghan, S.J.; Liu, Xiaohong; Rasch, P.J.; and Taylor, M.A., 2012, Description of the NCAR Community Atmosphere Model (CAM 5.0): National Center for Atmospheric Research Technical Note NCAR/TN-486+STR, 274 p.

Nebraska Department of Natural Resources, 2016a, Registered groundwater wells [shapefile]: Nebraska Department of Natural Resources, accessed April 19, 2016, at http://dnr.nebraska.gov/groundwater-data.

Nebraska Department of Natural Resources, 2016b, Surface water rights: Nebraska Department of Natural Resources database, accessed April 19, 2016, at http://www.dnr.ne.gov/ surface-water-rights.

New Mexico Office of the State Engineer, 2015, OSE wells: New Mexico Office of the State Engineer dataset, accessed April 18, 2016, at http://gisdata-ose.opendata.arcgis.com/ datasets/a1e1e3721ea6403b9e03e81f404918b7_0.

Oklahoma Water Resources Board, 2016, Water rights file geodatabase: Oklahoma Water Rights Board dataset, accessed April 18, 2016, at http://www.owrb.ok.gov/maps/ pmg/owrbdata_WR.html. 
Ostroff, Andrea; Wieferich, Daniel; Cooper, Arthur; Infante, Dana; and USGS Aquatic GAP Program, 2013, 2012 National Anthropogenic Barrier Dataset (NABD): U.S. Geological Survey, accessed April 21, 2016, at https://www.sciencebase.gov/ catalog/item/56a7f9dce4b0b28f1184dabd/.

Playa Lakes and Rainwater Basin Joint Ventures, 2016, GPLCC historic playa wetlands: Grand Island, Nebr., Great Plains Landscape Conservation Cooperative, accessed February 16, 2016, at https://www.sciencebase.gov/catalog/ item $/ 56$ be39cee4b06458514af171? community $=$ Great + Plains + Landscape + Conservation + Cooperative.

Playa Lakes Joint Venture, 2014, New Mexico playa decision support tools-Saline lakes [shapefile]: Playa Lakes Joint Venture, accessed December 11, 2014, at http://www.pljv.org/ playa-dss/new-mexico.

Reese, G.C., Manier, D.J., Carr, N.B., Callan, Ramana, Leinwand, I.I.F., Assal, T.J., Burris, Lucy and Ignizio, D.A., 2016, Estimated historical distribution of grassland communities of the Southern Great Plains: U.S. Geological Survey Open-File Report 2016-1184, 13 p., accessed December 12, 2016, at https://doi.org/10.3133/ofr20161184.

Rehfeldt, G.E., Crookston, H.L., Sáenz-Romero, Cuauhtémoc, and Campbell, E.M., 2012, North American vegetation model for land-use planning in a changing climate-A solution to large classification problems: Ecological Applications, v. 22, p. 119-141.

South Dakota Department of Environment and Natural Resources, 2016, South Dakota water rights: South Dakota Department of Environment and Natural Resources database, accessed April 18, 2016, at http://denr.sd.gov/des/wr/ dbwr.aspx.

Texas Commission on Environmental Quality, 2015, WARP [Water Rights Analysis Package] input files and GIS files by River Basin [shapefiles]: Texas Commission on Environmental Quality dataset, accessed February 2015 at http://www.tceq.texas.gov/permitting/water_rights/ wam.html/\#GIS.

Texas Parks and Wildlife Department, 2014, Texas Ecological Mapping Systems-Raster dataset: Texas Parks and Wildlife Department dataset, accessed July 24, 2014, at http://tpwd.texas.gov/landwater/land/programs/ landscape-ecology/ems/.
Texas Tech University Center for Geospatial Technology, 2014, Playa and wetlands of the southern Ogallala aquifer-Saline lakes geodatabase: Lubbock, Tex., Texas Tech University dataset, accessed December 11, 2014, at http://gis.ttu.edu/pwd/index.html.

Texas Water Development Board, 2016, Well locations from TWBD groundwater database [shapefile]: Texas Water Development Board dataset, accessed April 18, 2016, at https://www.twdb.texas.gov/mapping/gisdata.asp.

U.S. Army Corps of Engineers, 2015, National inventory of dams: U.S. Army Corps of Engineers database, accessed March 16, 2015, at http://nid.usace.army.mil. [Login required to access data].

U.S. Census Bureau, 2010, 2010 TIGER [Topologically Integrated Geographic Encoding and Referencing]/Line shapefiles: U.S. Census Bureau, Geography Division dataset, accessed February 5, 2016, at https://www.census.gov/ geo/maps-data/data/tiger.html.

U.S. Department of Transportation, 2014, National pipeline mapping system: U.S. Department of Transportation, Pipeline and Hazardous Materials Safety, accessed November 7, 2014, at https://www.npms.phmsa.dot.gov/.

U.S. Environmental Protection Agency and U.S. Geological Survey, 2012, NHDPlus 2.1 [vector digital data, tabular digital data]: U.S. Environmental Protection Agency and U.S. Geological Survey, accessed January 25, 2015, at http:// www.horizon-systems.com/NHDPlus/NHDPlusV2_data.php.

U.S. Forest Service and U.S. Geological Survey, 2016, National MTBS [Monitoring Trends in Burn Severity] Burned Area Boundaries dataset [shapefile]: U.S. Department of Agriculture and U.S. Geological Survey database, accessed August 8, 2016, at http://www.mtbs.gov/ nationalregional/burnedarea.html.

U.S. Geological Survey, 2014, NLCD [National Land Cover Database] 2006 percent developed imperviousness (2011 Edition): U.S. Geological Survey dataset, accessed February 5, 2016, at http://www.mrlc.gov/nlcd06_data.php. [Amended 2014.]

Wyoming State Engineer's Office, 2016, SEO wells shapefile: Wyoming State Engineer's Office dataset, accessed April 18, 2016, at http://seo.wyo.gov/documents-data/ maps-and-spatial-data. 
Publishing support provided by: Denver Publishing Service Center, Denver, Colorado

For more information concerning this publication, contact: Center Director, USGS Fort Collins Science Center 2150 Centre Ave., Bldg. C

Fort Collins, CO 80526-8118

(970) 226-9398

Or visit the Fort Collins Science Center website at: https://www.fort.usgs.gov/

This publication is available online at: https://doi.org/10.3133/ofr20171100 


\section{$\frac{\mathbb{2}}{3}$}

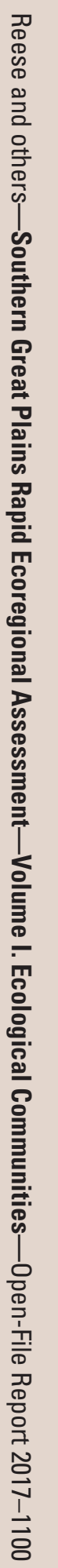

